Illinois State University

ISU ReD: Research and eData

Theses and Dissertations

$6-15-2020$

\title{
Oxadiazinones As Chiral Auxiliaries: Chiral Templates For Asymmetric Conjugate Addition In The Synthesis Of (R)-(+)- Tolterodine
}

Fatima Olayemi Obe

Illinois State University, obefatima@gmail.com

Follow this and additional works at: https://ir.library.illinoisstate.edu/etd

Part of the Organic Chemistry Commons

\section{Recommended Citation}

Obe, Fatima Olayemi, "Oxadiazinones As Chiral Auxiliaries: Chiral Templates For Asymmetric Conjugate Addition In The Synthesis Of (R)-(+)-Tolterodine" (2020). Theses and Dissertations. 1301.

https://ir.library.illinoisstate.edu/etd/1301

This Thesis is brought to you for free and open access by ISU ReD: Research and eData. It has been accepted for inclusion in Theses and Dissertations by an authorized administrator of ISU ReD: Research and eData. For more information, please contact ISUReD@ilstu.edu. 


\section{OXADIAZINONES AS CHIRAL AUXILIARIES: CHIRAL TEMPLATES FOR ASYMMETRIC CONJUGATE ADDITION IN THE SYNTHESIS \\ OF $(R)-(+)$-TOLTERODINE}

\section{FATIMA OLAYEMI OBE}

\section{Pages}

The stereoselective formation of carbon-carbon bonds through the process of conjugate addition has proven to be a very important methodology in synthetic organic chemistry. In this context, oxadiazinones are chiral auxiliaries that have been applied in the asymmetric aldol addition reaction to synthesize valuable synthetic fragments such as the aldol side chain of the multi-drug resistance medicinal agent, hapalosin. This thesis describes efforts that were directed towards employing oxadiazinones as chiral scaffolds for the process of asymmetric conjugate addition with the ultimate objective of using this methodology in the preparation of medicinal agents such as Tolterodine. Preliminary efforts focused on using an $\mathrm{N}_{4-} p$-methoxybenzyl substituted oxadiazinone to achieve these goals. This oxadiazinone was acylated with transcinnamic acid via the Steglich reaction with 1-ethyl-3-(3-dimethylaminopropyl) carbodiimide (EDC) and catalytic $N, N$-dimethylamino pyridine (DMAP). This substrate was then reacted with a Normant reagent, a mixture of the Grignard reagent, methylmagnesium bromide and copper (I) bromide-dimethylsulfide complex. The diastereoselectivity of the conjugate addition product was determined by analysis of the $500 \mathrm{MHz}{ }^{1} \mathrm{H}$ NMR spectrum to be no greater than $3: 1$, a value unsuitable for meaningful asymmetric synthesis. This observation was in contrast to higher stereoselectivities observed in the asymmetric aldol reaction with Ephedra based oxadiazinones 
where ratios of 95:5 are commonly observed. To resolve this issue, a new series of oxadiazinones were designed, namely $\mathrm{N}_{4}$-isopropyloxadiazinone and $\mathrm{N}_{4}-p$ diphenylmethyloxadiazinone. The observed diastereoselectivity of the asymmetric conjugate addition for the $\mathrm{N}_{4}$-isopropyloxadiazinone was lower. This reinforced the idea that the diastereoselectivity was being influenced by the conformational dynamics of the ring system and not just the $\mathrm{N}_{4}$-substituent. This thesis will describe the chemistry that has been accomplished to this point and make projections for future efforts in the synthesis of the medicinally valuable target compound, tolterodine (Detrol).

KEYWORDS: Chiral Auxiliaries; oxadiazinones; Acylation; Asymmetric; Conjugate Addition; Tolterodine 
OXADIAZINONES AS CHIRAL AUXILIARIES: CHIRAL TEMPLATES FOR ASYMMETRIC CONJUGATE ADDITION IN THE SYNTHESIS

OF $(R)-(+)$-TOLTERODINE

FATIMA OLAYEMI OBE

A Thesis Submitted in Partial

Fulfillment of the Requirements

for the Degree of

MASTER OF SCIENCE

Department of Chemistry

ILLINOIS STATE UNIVERSITY

2020 
(C) 2020 Fatima Olayemi Obe 
OXADIAZINONES AS CHIRAL AUXILIARIES: CHIRAL TEMPLATES FOR ASYMMETRIC CONJUGATE ADDITION IN THE SYNTHESIS

OF $(R)-(+)$-TOLTERODINE

FATIMA OLAYEMI OBE

COMMITTEE MEMBERS:

Shawn R. Hitchcock, Chair

Andrew Mitchell

Jeremy Driskell 


\section{ACKNOWLEDGMENTS}

Success is made easy when standing on the shoulder of giants. My PI, Dr. Shawn Hitchcock is one of those giants who is always willing to offer his shoulders to the younger scientists striving to rise. I thank him for being very patient and supportive. My appreciation also goes to Illinois State University and the admission committee of the Department of Chemistry for believing in me and offering me admission to this program. I am grateful for the financial support given to me in form of graduate assistantship, which has enabled me to study with no distractions. I will also like to appreciate all my professors for all the knowledge impacted to me. Each class I took definitely made me a better person who is more confident to face the future.

My profound gratitude also goes to my family; to my dear mother, Mrs. Florence Obe, who took up the responsibilities of both parents after dad's death. I thank my brother, Mr. Abiola Fagbamigbe for letting me know about ISU and for giving me all the necessary support to get me here. My profound gratitude also goes to my brother, Mr. Razaq Obe, for shouldering all my education expenses from undergraduate level up to this point. I equally appreciate all my siblings for their immeasurable contributions to my success stories, most especially my late sister who passed away few months to my graduation. She will forever remain in my mind for her immense contributions to my life.

I would also love to appreciate all the good people I have met in the US, both from Christian bodies and school, friends and colleagues we worked together through the tough semesters. They have all positively impacted my life more than they could possibly imagine. Above all, I give thanks to the almighty God for the gift of life and for the strength he gave to me to accomplish this great task. It would not have been possible without him. 


\section{CONTENTS}

Page

ACKNOWLEDGMENTS

FIGURES

SCHEMES Niii

CHAPTER I: INTRODUCTION 1

CHAPTER II: OXADIAZINONES AS CHIRAL AUXILIARIES IN

ASYMMETRIC CONJUGATE ADDITION REACTIONS 17

Introduction $\quad 17$

$\begin{array}{ll}\text { Results and Discussion } & 18\end{array}$

Ephedrine based oxadiazinones, synthesis, acylation and

asymmetric conjugate addition

Stereochemistry determination of (1R,2S)-ephedrine

$\begin{array}{ll}\text { conjugate addition product through classical resolution } & 24\end{array}$

Rationale to why the (S)-diastereomer was observed as the major isomer $\quad 28$

Pseudoephedrine based oxadiazinone, synthesis, acylation

and asymmetric conjugate addition

Norephedrine based oxadiazinone, synthesis, acylation and

asymmetric conjugate addition

Stereochemistry determination of (1R,2S)-norephedrine

conjugate addition product through hydrolysis

Rationale for the low diastereoselectivities and stereochemical

orientation of the major isomer 
More efforts towards increasing the diastereoselectivity of the conjugate addition: The $\mathrm{N}_{4}$-para-methoxybenzyloxadiazinone from L-phenyl alaninol, synthesis and application Acylation and asymmetric conjugate addition with L-phenylalaninol-N 4 -para-methoxybenzyl-oxadiazinone Initial attempts to increase the diastereoselectivity of the conjugate addition: The L-phenylalaninol- $\mathrm{N}_{4}$-isopropyl oxadiazinone synthesis and application Acylation and asymmetric conjugate addition with the $\mathrm{N}_{4}$-isopropyloxadiazinone

Further attempts to increase the diastereoselectivity of the conjugate addition:

The L-phenylalaninol-N $\mathrm{N}_{4}$-diphenylmethyloxadiazinone and the L-phenylalaninol- $\mathrm{N}_{4}$-(1,3-diphenyl-2 propyl) oxadiazinone Proposed attempt to increase the diastereoselectivity of the conjugate addition: the $\mathrm{N}_{4}$-1,3-diphenyl-2-propyloxadiazinone Proposed acylation and asymmetric conjugate addition with the $\mathrm{N}_{4}$-1,3-diphenyl-2-propyloxadiazinone Proposed attempt to increase the diastereoselectivity of the conjugate addition: $\mathrm{N}_{4}$-diphenylmethyloxadiazinone 
CHAPTER III: CONCLUSION AND FUTURE DIRECTIONS

$\begin{array}{lc}\text { REFERENCES } & 69\end{array}$

$\begin{array}{ll}\text { APPENDIX A: EXPERIMENTALS } & 75\end{array}$

APPENDIX B: SELECTED NMR SPECTRA 121 


\section{FIGURES}

Figure

Page

1. Chirality and biomolecules 2

2. Enantioselectivity of biological receptors 3

3. Examples of eutomers (pharmacologically active enantiomers) 3

4. The $(S)$-enantiomer (left) and the $(R)$-enantiomer of thalidomide 4

5. Chiral auxiliaries for diastereoselective conjugate addition reactions $\quad 7$

6. Various amino acids source for the Evans' oxazolidinones formation 9

7. Structural modifications to the Evans' chiral auxiliary 10

8. Examples of chiral oxadiazinones 11

9. Chiral relay in oxadiazinone mediated asymmetric aldol

$\begin{array}{ll}\text { reactions: X-ray crystal structure } & 13\end{array}$

10. Tolterodine 14

11. Proposed oxadiazinone mediated asymmetric conjugate addition pathway 17

12. $500 \mathrm{MHz}{ }^{1} \mathrm{H}$ NMR spectrum of the conjugate addition

product of $(1 R, 2 S)$-ephedrine based oxadiazinone 23

13. $500 \mathrm{MHz}{ }^{1} \mathrm{H}$ NMR spectrum of the product of Steglich reaction between the $(1 R, 2 S)$-ephedrine based oxadiazinone and (S)-(+)-3-phenylbutyric acid (60a)

14. $500 \mathrm{MHz}{ }^{1} \mathrm{H}$ NMR spectrum of the conjugate addition product of $(1 R, 2 S)$-ephedrine based oxadiazinone

15. $500 \mathrm{MHz}{ }^{1} \mathrm{H}$ NMR spectrum of the conjugate addition product of $(1 S, 2 S)$-pseudoephedrine system 
16. $125 \mathrm{MHz}{ }^{13} \mathrm{C}$ NMR spectra comparing the conformational rigidity of the ephedrine based oxadiazinone $(43$, top $)$ and the pseudoephedrine based oxadiazinone (71, bottom) systems

17. The Ephedra based oxadiazinones

18. The Ephedra alkaloids as the key starting materials

for the formation of the oxadiazinones

19. $500 \mathrm{MHz}{ }^{1} \mathrm{H}$ NMR spectrum of the $(1 R, 2 S)$-norephedrine based $\mathrm{N}_{4}$ - $p$-methoxybenzyl-N 3 -(3-phenylbutanoyl) oxadiazinone (81)

20. $500 \mathrm{MHz}{ }^{1} \mathrm{H}$ NMR spectrum of the $(1 R, 2 S)$-norephedrine based $\mathrm{N}_{4}$-p-methoxybenzyl-N 3 -(3-phenylbutanoyl) oxadiazinone (82)

21. Investigation of conformational rigidity of the norephedrine based system by $125 \mathrm{MHz}{ }^{13} \mathrm{C}$ NMR

22. Rationale for the observed stereoselectivity in the norephedrine based system

23. Comparison between the norephedrine and the L-phenylalaninol based oxadiazinones

24. Increasing the steric demand of the $\mathrm{N}_{4}$-substituent 48

25. The design of a new L-phenylalaninol based $\mathrm{N}_{4}$-isopropyl Oxadiazinone 
26. $500 \mathrm{MHz}{ }^{1} \mathrm{H}$ NMR spectrum of the

$\mathrm{N}_{4}$-isopropyl-N 3 -(3-phenylbutanoyl) oxadiazinone

diastereomers $(98 \mathbf{a} \boldsymbol{\&} \mathbf{9 8 b})$ conjugate addition product

27. $500 \mathrm{MHz}{ }^{1} \mathrm{H}$ NMR spectrum of the

$\mathrm{N}_{4}$-isopropyl-N 3 -(3-phenylbutanoyl) oxadiazinone (99a \& 99b)

diastereomers

28. Potential alteration of configuration in the conjugate

addition starting material for the isopropyl system

29. Proposed solution to the configuration

flexibility of the isopropyl system

30. Proposed design improvement of the $\mathrm{N}_{4}$-substituted oxadiazinone.

31. Structural comparison between the $\mathrm{N}_{4}$-isopropyl and

the $\mathrm{N}_{4}$-1,3-diphenyl-2-propyl oxadiazinones

60

32. Structural comparison between the $\mathrm{N}_{4}$-1,3-diphenyl-2-propyl

oxadiazinones (101) and the $\mathrm{N}_{4}$-diphenylmethyl oxadiazinones (102)

64 


\section{SCHEMES}

Scheme

Page

1. Racemization of thalidomide in a biological

environment

2. The Ortiz asymmetric application of the Evans'

oxazolidinone

3. The Takayama asymmetric application of the Evans'

oxazolidinone

4. General pathway for asymmetric synthesis using the

Evans' oxazolidinones

5. Oxadiazinones in the asymmetric aldol addition reaction

6. General pathway of conjugate addition reaction with

the oxazolidinone and proposed conjugate addition pathway

with the oxadiazinones

7. Proposed pathway for tolterodine synthesis using

the oxadiazinones as chiral templates

8. Synthesis of $(1 R, 2 S)$-ephedrine based oxadiazinone $\mathbf{2 5}$

9. The N-nitrosation reaction mechanism for the

formation of compound $\mathbf{5 3}$

10. The lithium aluminum hydride reduction reaction

mechanism for the formation of compound $\mathbf{5 4}$

11. The cyclization reaction mechanism for the

formation of compound 34 
12. Acylation and conjugate addition with the $(1 R, 2 S)$-ephedrine based oxadiazinone for the formation of compound $\mathbf{5 9}$

13. Mechanism of reaction for the oxadiazinone acylation for the formation of compound $\mathbf{4 3}$

14. Mechanism of reaction for the asymmetric conjugate addition reactions leading to the formation of compound $\mathbf{5 9}$

15. Stereochemistry determination by classical resolution

16. Stereochemistry determination: polarimetric analysis

17. Stereochemistry determination: Steglich reaction with the recovered butyric acid

18. Rationale for the observed stereoselectivity in the ephedrine-based system

19. Synthesis of the $(1 S, 2 S)$-pseudoephedrine based oxadiazinone $\mathbf{7 0}$

20. Acylation of the $(1 S, 2 S)$-pseudoephedrine based oxadiazinone $\mathbf{7 0}$

21. Asymmetric conjugation addition with the

$(1 S, 2 S)$-pseudoephedrine- $\mathrm{N}_{3}$-cinnamoyloxadiaxinone

22. Synthesis of the $(1 R, 2 S)$-norephedrine-N $4-p$-methoxybenzyl

oxadiazinone, 73

23. Reductive amination reaction mechanism for the formation of $\mathrm{N}_{4}$ - $p$-methoxybenzyl amino alcohol, 75 
24. Acylation reactions with the $(1 R, 2 S)$ - norephedrine-based

oxadiazinone using (a) trans cinnamic acid and (b)

trans crotonyl chloride, for the formation of the acylated

products $\mathbf{7 8}$ and $\mathbf{8 0}$

25. Asymmetric conjugation addition in the formation of compound $\mathbf{8 1}$

26. Asymmetric conjugation addition in the formation of compound $\mathbf{8 2}$

27. The norephedrine stereochemistry determination by

hydrolysis and polarimetric analysis

28. Synthesis of the L-phenylalanine based

N4-para-methoxybenzyl-oxadiazin-2-one, 89

29. Acylation of the L-phenylalanine based

$\mathrm{N}_{4}$-para-methoxybenzyl-oxadiazinone, 89

30: Asymmetric conjugation addition reaction with the

$\mathrm{N}_{4}$-para-methoxybenzyl-N 3 -cinnamoyl oxadiazinone 91

31. Synthesis of the L-phenylalaninol based $\mathrm{N}_{4}$-isopropyloxadiazinone

32. Mechanism for the formamidine sulfinic acid

reduction of N-nitrosamine $\mathbf{5 8}$

33. Synthesis of $\mathrm{N}_{4}$-isopropyl- $\mathrm{N}_{3}$-cinnamoyloxadiaxinone

34. Synthesis $\mathrm{N}_{4}$-isopropyl- $\mathrm{N}_{3}$-crotonyloxadiaxinone

35. Synthesis of the $\mathrm{N}_{3}-\left(3\right.$-phenylbutanoyl)- $\mathrm{N}_{4}$-isopropyl

oxadiazinone (98)

36. Synthesis of the $\mathrm{N}_{3}$-(3-phenylbutanoyl)- $\mathrm{N}_{4}$-isopropyl

oxadiazinone (75a \& 75b) 
37. Observation from the $500 \mathrm{MHz}{ }^{1} \mathrm{H}$ NMR spectra of the metal complexing reactions with the $\mathrm{N}_{4}$-isopropyl- $\mathrm{N}_{3}$-(3-phenylbutanoyl) oxadiazinone

38. Proposed synthesis of the L-phenyl alaninol based

$\mathrm{N}_{4}$-1,3-diphenyl-2-propyloxadiazinone

39. Proposed Steglich reaction (top) and crotonyl acylation of the $\mathrm{N}_{4}$-1,3-diphenyl-2-propyloxadiazinone

40. Proposed asymmetric conjugation addition with the $\mathrm{N}_{4}$-1,3-diphenyl-2-propyloxadiazinone

41. Synthesis of the $\mathrm{N}_{4}$-diphenylmethyl oxadiazinones (102) 64

42. Attempted $\mathrm{N}$-nitrosation of $N$-diphenylmethyl-L-phenylalaninol 65

43. N-nitrosation of $N$-diphenylmethyl-L-phenylalaninol

with sodium nitrite and hydrochloric acid

66 


\section{CHAPTER I: INTRODUCTION}

The term chirality comes from the Greek word "kheir-, hand" which implies "handedness". ${ }^{1}$ Chiral molecules have the ability to exist in right- and left-hand forms and are categorized under a broad class of isomers known as stereoisomers. Stereoisomers are molecules with the same molecular and structural formulae but differ in the spatial arrangement of the atoms. This isomerism is a result of the presence of an atom, often a carbon atom, in the molecule, that is connected to four unique substituents. Such atoms are called chiral centers or stereocenters. If two stereoisomeric molecules are mirror images of each other and are not superimposable, they are referred to as enantiomers. However, if the stereoisomeric molecules cannot be related by a mirror plane, they are known as diastereomers. Enantiomers and diastereomers have major differences. While enantiomers may have one or more chiral centers, diastereomers that possess chirality must have at least two chiral centers. In addition, although enantiomers rotate plane polarized light in equal magnitude but opposite directions, they exhibit the same physical and chemical properties. In contrast, diastereomers usually differ in their physical and chemical properties, a characteristic exploited in this thesis project. Because enantiomers have identical enthalpies and entropies from when they arise from chemical reactions, they are usually obtained in equal amounts and this mixture is called a "racemic mixture". ${ }^{2}$ Based on how the four unique substituents are arranged in space around the chiral centers of each enantiomer, they are described as either $R$-isomer or $S$-isomer.

The importance of selectively synthesizing one enantiomer over the other in a biologically active molecule cannot be overemphasized. Due to identical composition and functional groups, enantiomers may exhibit similar chemical and physical properties, yet, they 
may differ in their medicinal efficacy in biological environments. ${ }^{3}$ This is directly linked with the ability of naturally occurring biomolecules such as enzymes to discriminate between different enantiomers due to the intrinsic chirality of enzymes. ${ }^{4}$ In fact, most biomolecules that make up our body systems are chiral in nature (Figure 1). ${ }^{5}$ For instance, proteins are composed of $\alpha$-amino acids, most of which are chiral in nature. These biomolecules make up receptors in the human body and these receptors could be highly stereoselective.

Figure 1. Chirality and biomolecules.
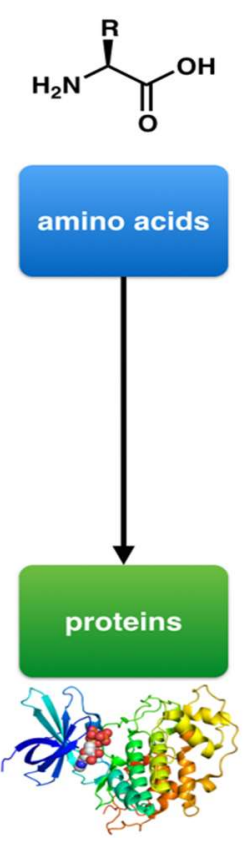
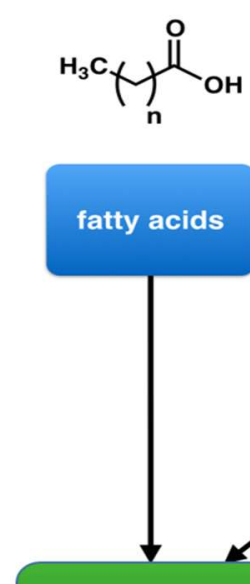

Lipids
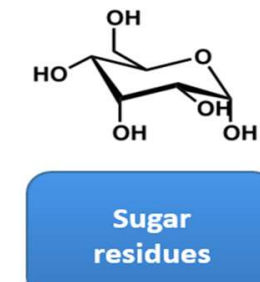
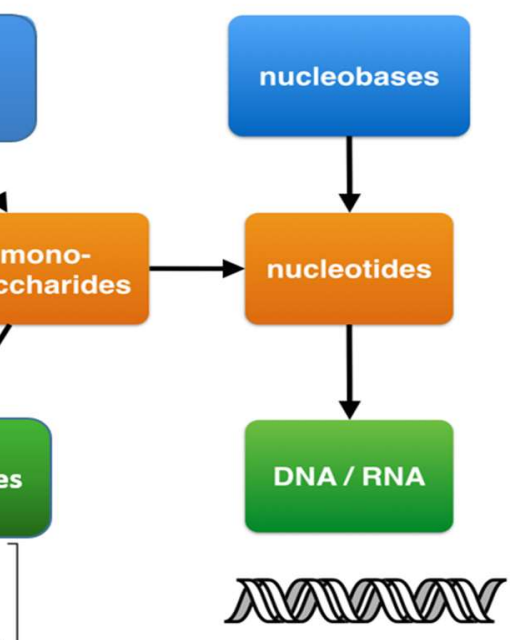

As a result, a particular enantiomeric molecule may strongly interact with a biological receptor while the other enantiomer may only have a weak interaction (Figure 2). ${ }^{6}$ The implication of this is that one enantiomer of a drug may be effective in treating a certain disease while the other enantiomer may be weakly therapeutic, inactive, or toxic. In such cases, the active enantiomer is known as a eutomer while the inactive enantiomer is known as a distomer. 
Figure 2. Enantioselectivity of biological receptors.
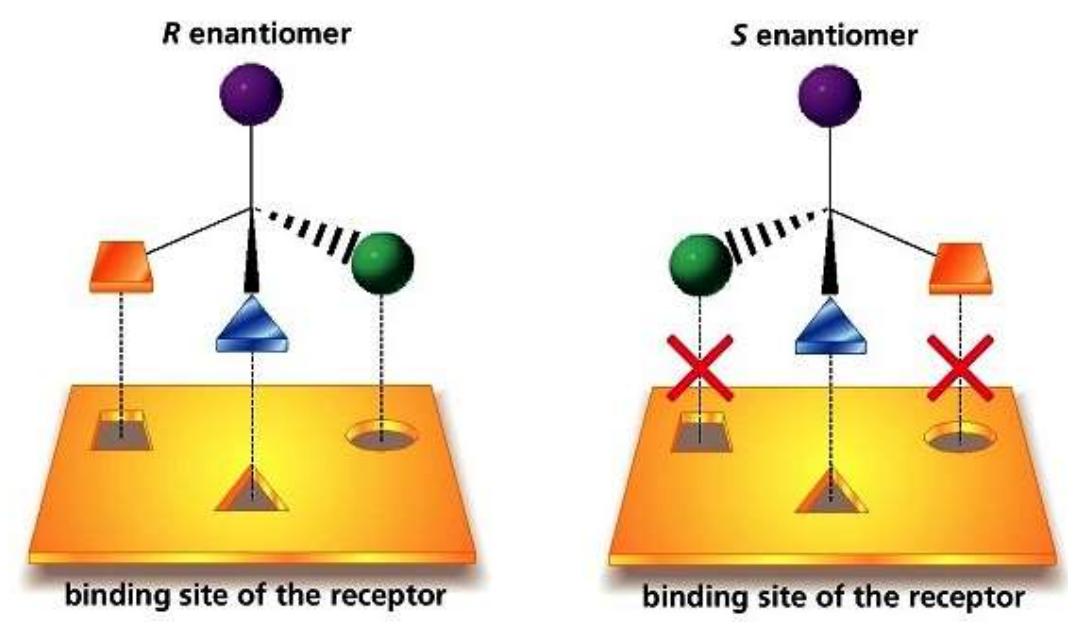

There are numerous examples of drugs that fall into this category (Figure 3); Albuterol is a block buster drug that is sold as a racemic mixture and used in anti-asthmatic inhalant. The $(R)$ isomer is the major active ingredient of the drug while the $(S)$-Albuterol (1) is significantly less effective. ${ }^{7}$ Another example is an antidepressant drug sold under the trade name Zoloft (2) which belongs to a group of compounds known as the aminotetralins. ${ }^{8}$ The $(1 R, 4 S)$-enantiomer of Zoloft is the eutomer while the $(1 S, 4 R)$-enantiomer has no activity against depression. In the same vein, $(R)$-penicillamine (3) is an antidote against metal poisoning while the opposite enantiomer is capable of causing total blindness. ${ }^{9}$

Figure 3. Examples of eutomers (pharmacologically active enantiomers).<smiles>CC(C)(C)NCC(O)c1ccc(O)c(CO)c1</smiles>

(R)-Albuterol, 1<smiles>CNC1CCC(c2ccc(Cl)c(Cl)c2)c2ccccc21</smiles>

Zoloft, 2<smiles>CC(S)(S)[C@H](N)C(=O)O</smiles>

(R)-Penicillamine, 3 
The fact that stereochemistry has a direct influence on the potency and sometimes, on the toxicity of the drugs,${ }^{10}$ makes it important to consider the pharmacological effects of drugs in their two enantiomerically pure forms and as the racemic mixture. Consequently, the topic under discussion possesses high relevance in the pharmaceutical industry.

Of all the cases of different side effects associated with the use of a drug as a racemic mixture ever reported, the most catastrophic of all is the thalidomide incident which occurred in the 1950s. ${ }^{11,12}$ Thalidomide (Figure 4) was a drug synthesized by a German pharmaceutical company known as Grünenthal Chemie in the 1950s. The drug was primarily distributed in Germany, Australia and Canada and was reported further distributed in more than 46 countries. The drug was administered to pregnant women with the sole aim of suppressing morning sickness. It was ultimately discovered that those women who took thalidomide gave birth to deformed babies. Some babies were born with deformed arms and legs, some had deformed faces while some were too deformed to survive. About 2,000 deaths were recorded as a result of thalidomide and more than 10,000 deformed babies were reported. ${ }^{13}$

Figure 4. The (S)-enantiomer (left) and the $(R)$-enantiomer of thalidomide.

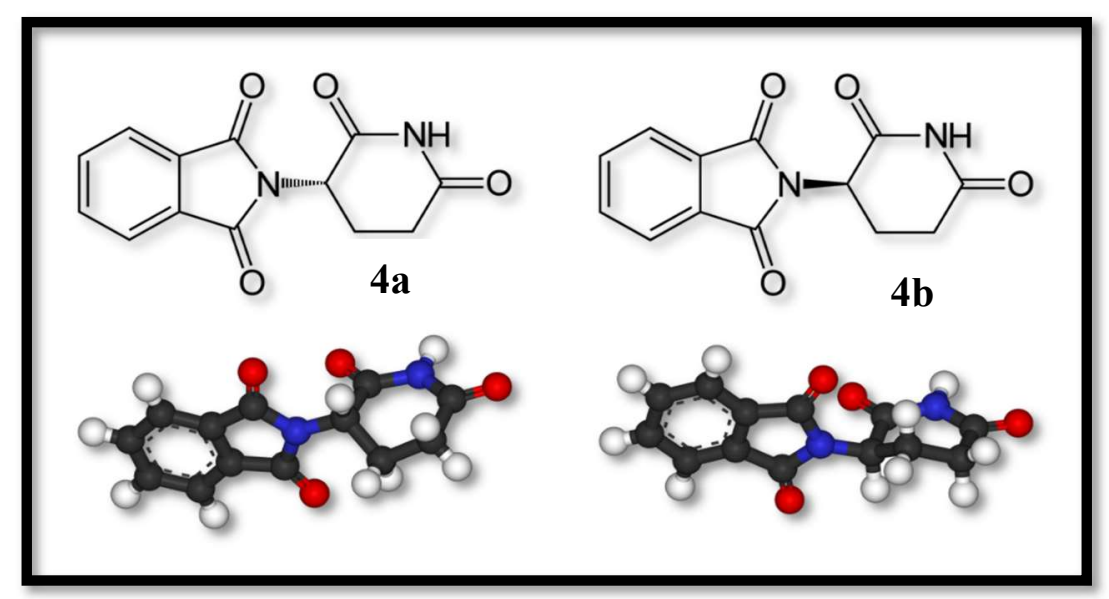


Nearly two decades after the onset of the thalidomide tragedy, researchers unraveled the mystery behind the incident. ${ }^{14 a}$ It was noted that the drug was sold as a racemic mixture of the $(R)$ - and $(S)$-enantiomers as illustrated in Figure 4. The $(R)$-enantiomer (4b) has a sedative effect, relieving pregnant women of morning sickness while the $(S)$-enantiomer $\mathbf{( 4 a )}$ is a teratogen that interferes with fetal development. It was initially thought that the individual enantiomers could be separated so that there could still be therapeutic value for pregnant women dealing with morning sickness. Unfortunately, the $(R)$ - and $(S)$-enantiomers interconvert in vivo thereby making the separation of enantiomers of no practical value (Scheme 1). ${ }^{14 b}$

Scheme 1. Racemization of Thalidomide in a biological environment.

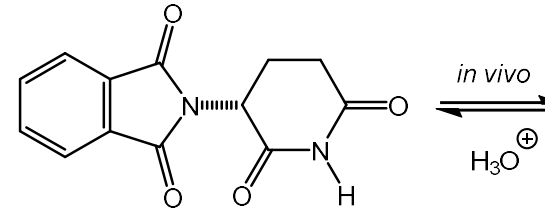

(S)-thalidomide, $\mathbf{4 a}$ Teratogen!

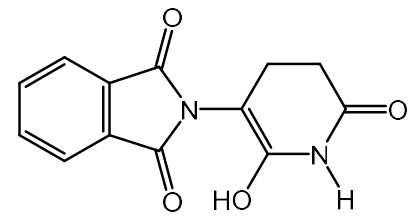

5

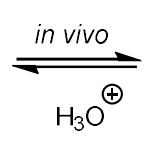

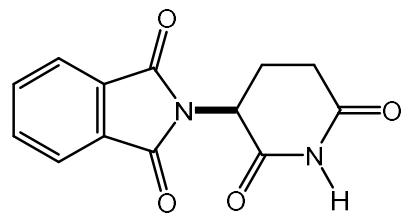

(R)-thalidomide, $\mathbf{4 b}$

A study conducted in Brazil in 2016 and reported in the European Journal of Medical

Genetics showed that thalidomide children are still being born yearly. ${ }^{14 \mathrm{c}}$ Even though the World Health Organization (WHO) initially withdrew the drug from the market, its sale was later allowed due to its effectiveness in treating other diseases such as leprosy. It was proposed by the authors that the availability of thalidomide to pregnant women in Brazil trying to manage leprosy symptoms led to the birth of numerous deformed children in 2016.

Thalidomide is a paramount example of the importance of molecular chirality in pharmaceutical agents. Even though there is no value in isolating the individual enantiomers, it is 
an important lesson in the differing levels of biological activity of enantiomers. Reactions that are designed to selectively form one enantiomer over the other are collectively known as stereoselective reactions. Such reactions can be further described as being asymmetric reactions or asymmetric syntheses.

Asymmetric synthesis involves inducing chirality into a substrate, preferentially forming one stereoisomer over the other; this process is formally known as asymmetric induction. One way of achieving asymmetric synthesis is through the use of compounds known as chiral auxiliaries. Chiral auxiliaries are organic compounds with pre-existing fixed chiral centers. They therefore assist in preferentially establishing the stereochemistry of a new chiral center in molecules. As such, the usage of chiral auxiliaries has been proven to be an effective tool in controlling asymmetry in a wide variety of reactions. ${ }^{15}$ Beyond this, the stereoselective formation of carbon-carbon bonds through the process of asymmetric conjugate addition has proven to be a very important methodology in synthetic organic chemistry. ${ }^{16-18}$ The use of chiral auxiliaries to guide the stereoselective bond formation has continued to be a reliable methodology for obtaining products in high diastereoselectivity (Figure 5).

Koga's lactam (6) was one of the first chiral auxiliaries successfully used in the process of asymmetric conjugate addition. ${ }^{19}$ The diastereoselectivities for this process were high, but the chiral auxiliary did not offer the practicality of ease of preparation. This auxiliary would be followed by the more successful application of Oppolzer's sultam (7). ${ }^{20-24}$ The sultam is based on the D-camphor template and has proven to be applicable in a variety of conjugate addition applications. Another chiral auxiliary that has been employed for the process of asymmetric conjugate addition is Chiacchio and Romeo's bicyclic sultam (8). ${ }^{25}$ While not as employed to the 
same degree as Oppolzer's sultam, the bicyclic sultam template was still successful in its applications.

Figure 5. Chiral auxiliaries for diastereoselective conjugate addition reactions.

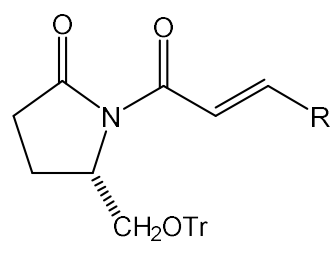

Tomioka and Koga et al., 6

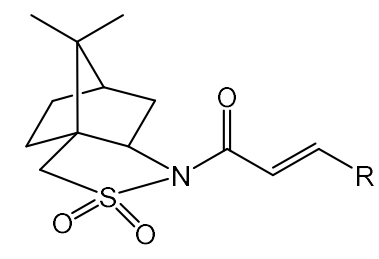

Oppolzer et al., 7

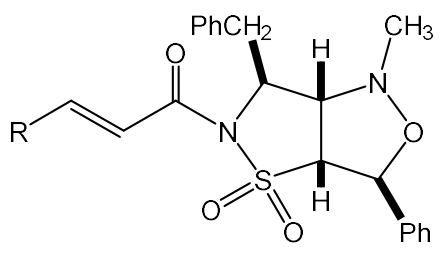

Chiacchio and Romeo et al., 8<smiles>[R]C=CC(=O)N(C)[C@@H](C)[C@H](O)c1ccccc1</smiles>

Badia et al., 9

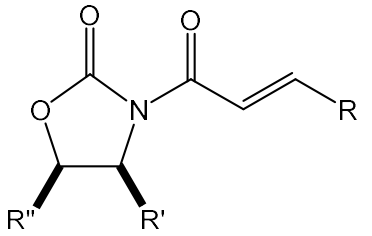

Evans et al., 10

Badía and coworkers ${ }^{26-29}$ developed a more practical chiral auxiliary based on using Myers'(1S,2S)-pseudoephedrine (9) ${ }^{30 \mathrm{a}, \mathrm{b}}$ template as a chiral template for asymmetric conjugate addition. While this chiral template has proven to be very useful, the dominant chiral auxiliary that has been employed in chiral auxiliary mediated asymmetric conjugate additions is the Evans' oxazolidinone (10). ${ }^{31-38}$ The Evans' auxiliary has proven to be the most versatile of all of the auxiliaries presented here. While catalytic asymmetric conjugate addition methods are continuing to increase in their applications, the Evans' oxazolidinone remains as a viable option to achieve asymmetric synthetic ends. In this context, in 2019 , Ortiz and coworkers ${ }^{39,40}$ were able to synthesize a series of gamma-amino acids by this methodology (Scheme 2). 
Scheme 2. The Ortiz asymmetric application of the Evans' oxazolidinone.

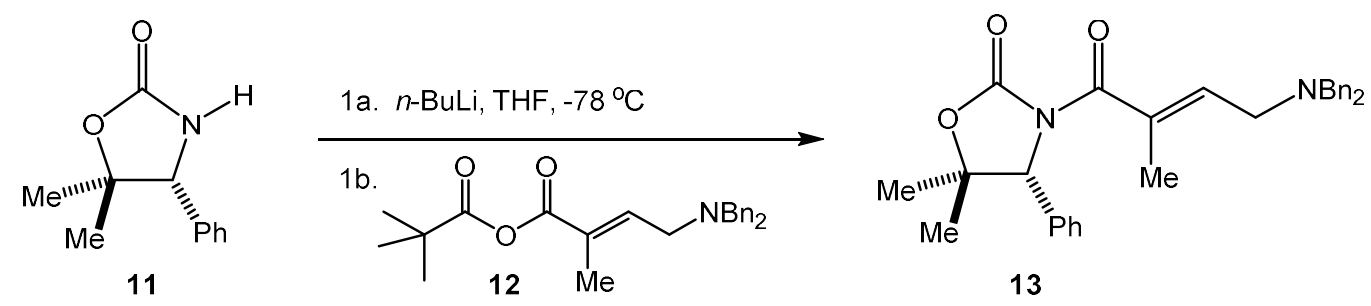<smiles>[R3]C(CN)C([Y5])C(=O)O</smiles>

Also, Takayama and coworkers employed the Evans' oxazolidinone in the synthesis of the Lycopodium alkaloid Lycopoclavamine-A via an asymmetric conjugate addition (Scheme 3). ${ }^{41}$

Scheme 3. The Takayama asymmetric application of the Evans' oxazolidinone.<smiles>C/C=C/C(=O)N1C(=O)OC[C@H]1Pc1ccccc1</smiles>

Tamaka et al. 2019,16

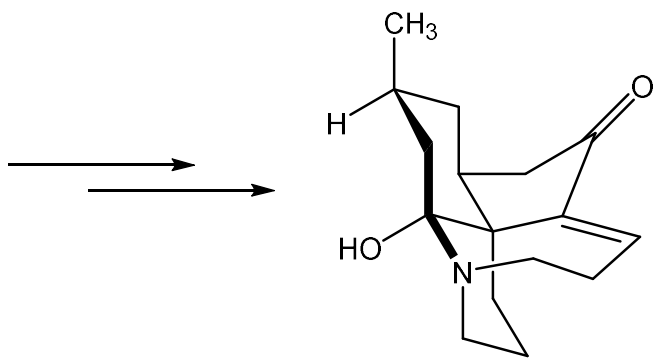

Lycopoclavamine-A 17

The most commonly used of the Evans' chiral auxiliary are derived from naturally occurring compounds such as L-phenylalanine (18) and L-valine (20) and some unnatural $\alpha$ amino acids such as L-phenylglycine (19), L-tert-leucine (21) and modified L-serine (22) (Figure 
6). The use of the Evans' chiral auxiliary in asymmetric synthesis follows a general pathway of acylation and conjugate addition reactions (Scheme 4). ${ }^{31-36}$ For the oxazolidinones, the $\mathrm{C}_{4-}$ position is the stereochemical controlling element.

Figure 6. Various amino acids source for the Evans' oxazolidinones formation.

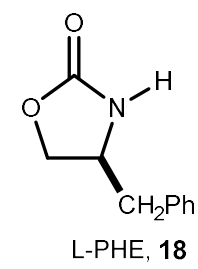

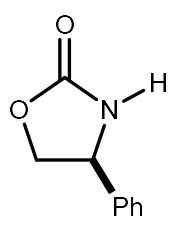

L-PHG, 19
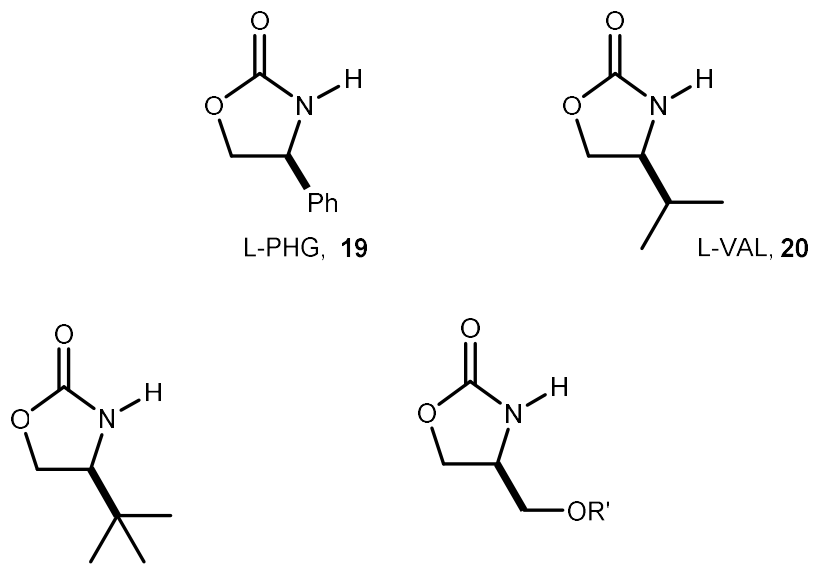

L-t-LEU: 21

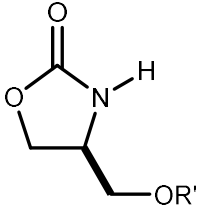

Modified L-SER, 22

Scheme 4. General pathway for asymmetric synthesis using the Evans' oxazolidinones.

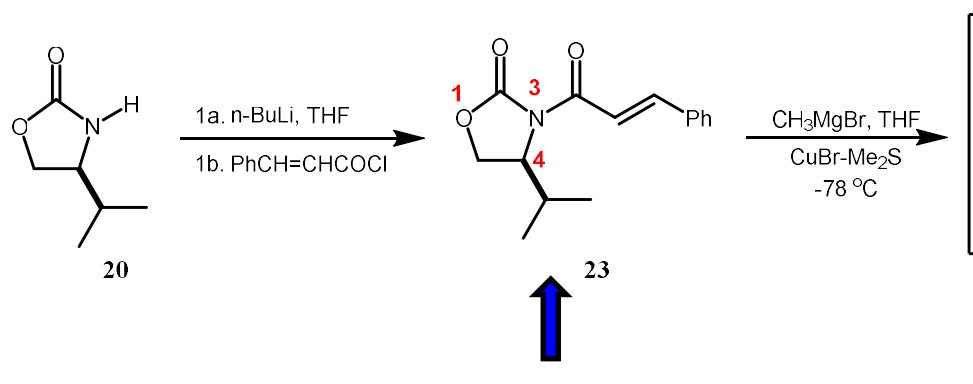

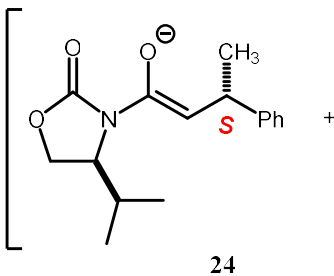

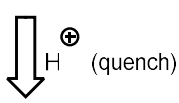

Stereochemical control element<smiles>CC(P)C=C([O])N1C(=O)OCC1C(C)C</smiles>
25<smiles>C=CCCCC</smiles><smiles>[R]C(CC(=O)N1C(=O)OC[C@H]1C(C)C)c1ccccc1</smiles>

Dominant diastereomer 
Several researchers have carried out structural modifications on the Evans' fivemembered-ring oxazolidinone by varying the substituent at the $\mathrm{C}_{4}$-position with the goal of achieving an improved diastereoselectivities (Figure 7). ${ }^{42-48}$

Figure 7. Structural modifications to the Evans' chiral auxiliary.

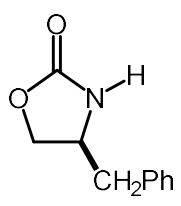

Evans et al., 18

JACS 1982, 104, 1737

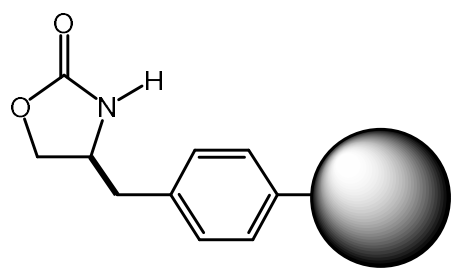

Abell et al., 31

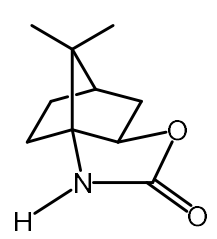

Yan et al., 28

JACS 1993, 115, 2613

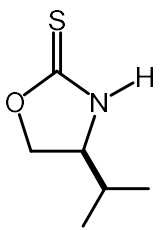

Crimmins et al., 32

Org. Lett. 2000, 2, 775

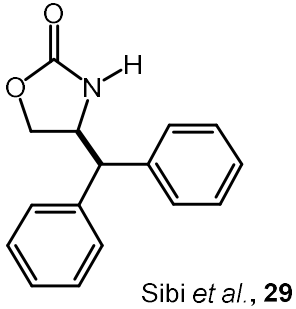

Tet. Lett. 1995, 36, 8965

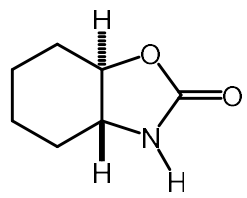

de Parrodi et al, 33

Tet. Asymm. 2001, 12, 69

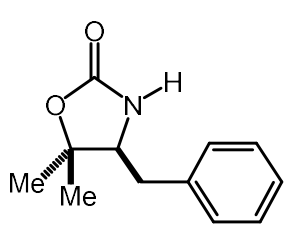

Davies et al., 30

Tet. Asymm. 1995, 6, 671

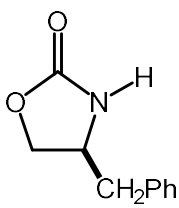

Williams et al., 18

JOC 2020, Just accepted

Some of the structural modifications include the introduction of diphenyl methyl group by Sibi and coworkers (29), introduction of a polymer backbone by Abell et al. (31), introduction of sulfur analog by Crimmins et al. (32), conversion into a bicyclic structure by de Parrodi et al. (33) and so on. However, the original Evans' oxazolidinone developed in the early 1980s (18) has withstood the test of time as it was recently used by Williams and coworkers in their synthesis of Baulamycin A recently published in the Journal of Organic Chemistry in January 2020.49 
The successful application of the Evans' auxiliary in numerous conjugate addition applications served as the impetus for the proposed research described herein. There was an interest in conducting asymmetric conjugate addition reactions, but it was decided to take a different route other than modifying the classical oxazolidinones. This led us to a six-membered ring class of compounds known as the oxadiazinones (34). In this context, oxadiazinones are chiral auxiliaries that are structurally related to the Evans' oxazolidinone as aza-homologs. Oxadiazinones represent a class of heterocycles that were first prepared by the Dow Chemical Company in a research program led by Trepanier and coworkers ${ }^{50,51}$ in the $1960 \mathrm{~s}$. The goal of synthesizing the oxadiazinones by Dow was not for it to be used as a chiral auxiliary. Rather, it was meant to serve as a therapeutic agent. It was tested against Parkinson disease and some cardiovascular diseases, of which in both cases, it was found ineffective. As a result, literature references concerning the Ephedra based oxadiazinones became sparse from the chemical literature for about two decades. Not until the late 1990s when it was employed by Husson and coworkers in diastereoselective alkylations $(\mathbf{3 5})^{52}$ and asymmetric dipolar cycloadditions (36) ${ }^{53,54}$ (Figure 8).

Figure 8. Examples of chiral oxadiazinones.

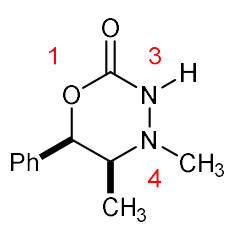

34

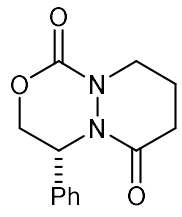

35

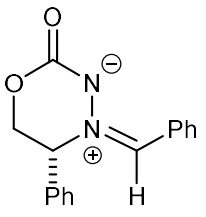

36

Our research group first utilized the oxadiazinones as chiral auxiliaries in the early 2000 s where they were applied as chiral auxiliaries in the asymmetric aldol addition reaction (Scheme 
5). ${ }^{55,56}$ The success of the asymmetric induction in the oxadiazinone mediated aldol reaction is believed to be due to the stereogenic $\mathrm{N}_{4}$-nitrogen which serves at the stereochemical control element guiding the reaction.

Scheme 5. Oxadiazinones in the asymmetric aldol addition reaction.

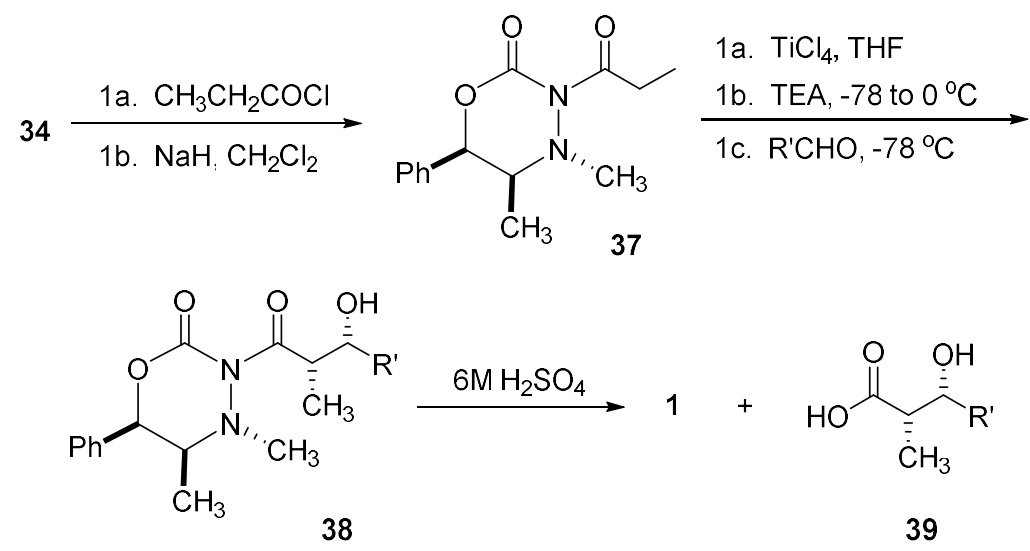

This is partially based on the fact that the observed diastereoselectivities for the asymmetric aldol reaction ranges from 3:1 to 99:1 when the $\mathrm{N}_{4}$-substituent is a methyl group, and ranges from 10:1 to 99:1 when the $\mathrm{N}_{4}$-substituent is a much larger isopropyl group. The conformation and the configuration of the $\mathrm{N}_{4}$-nitrogen is a result of chiral relay where stereochemical information is relayed from the $\mathrm{C}_{5}$ and $\mathrm{C}_{6}$ positions of the oxadiazinone ring system. An $\mathrm{X}$-ray crystal structure for aldol adduct (Figure 9) was obtained and serves to suggest that it is the $\mathrm{N}_{4-}$ position that directs the stereochemistry of the aldol process. 
Figure 9. Chiral relay in oxadiazinone mediated asymmetric aldol reactions: X-ray crystal structure.

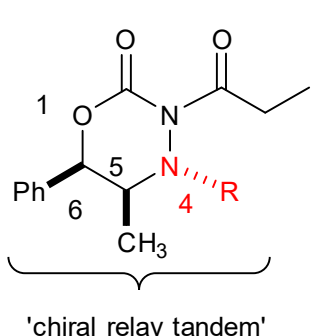

37

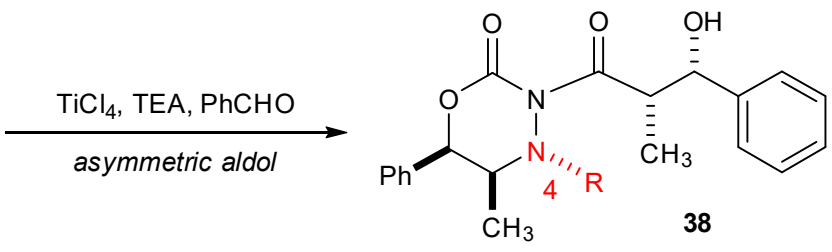

The conformational position of the $\mathrm{N}_{4}$-methyl substituent controls the stereochemical outcome of the aldol reaction.

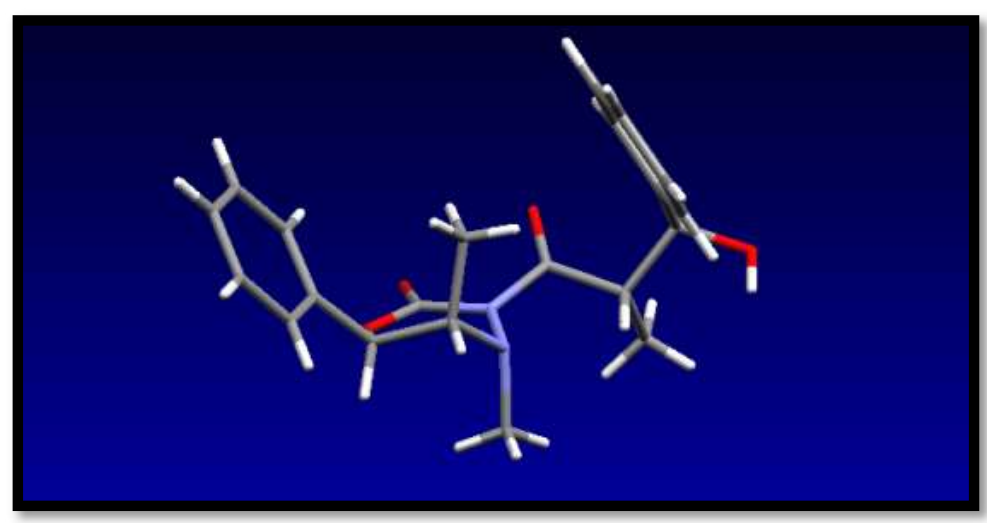

The high diastereoselectivity achieved with the oxadiazinones in the asymmetric aldol addition reaction suggested that this chiral auxiliary could be employed as well as chiral templates in asymmetric conjugate addition reactions. Thus, the proposed research would follow the same reaction pathway as the oxazolidinones of Evans' in the use of oxadiazinones as chiral auxiliaries (Scheme 6). Should the oxadiazinone-guided asymmetric conjugate addition reaction be successful, then it will be employed as a chiral template in the synthesis of the medicinal agent tolterodine. 
Scheme 6. General pathway of conjugate addition reaction with the oxazolidinone and proposed conjugate addition pathway with the oxadiazinones.

A

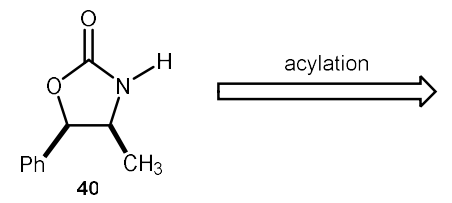

B<smiles>CC1C(c2ccccc2)OC(=O)NN1C</smiles><smiles>CC1C(P)OC(=O)N1C(=O)/C=C/P</smiles>

$\stackrel{\text { conjugate addition }}{\longrightarrow}$

4

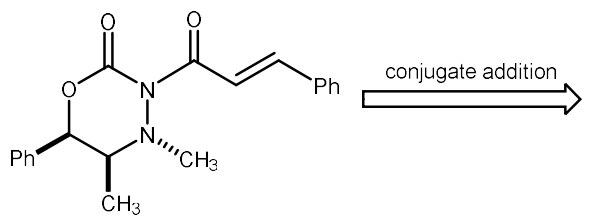

43

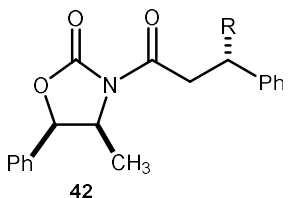<smiles>CC(P)CC(=O)N1C(=O)OC(c2ccccc2)C(C)N1C</smiles>

Tolterodine (45) (Figure 10) is a medicinal agent distributed under the trade name Detrol and sold by Pfizer, Inc. It belongs to a class of drugs known as antispasmodics used in countering involuntary contraction of muscles. Tolterodine is specifically used in the treatment of overactive bladder. It helps in relaxing the muscles in the bladder and thereby improves the patient's ability to control urination. It helps in reducing urine leakage, feelings of frequent urination and ultimately prevent frequent bathroom visits..$^{57,58}$

Figure 10. Tolterodine<smiles>Cc1ccc(O)c(C(CCN(C(C)C)C(C)C)c2ccccc2)c1</smiles>

Tolterodine (Detrol), 45 
It is proposed that tolterodine will be synthesized following the general pathway of acylation using the Steglich reaction (Figure 11). This will involve the acylation of the heterocycle (34) with trans-cinnamic acid to obtain the acylated oxadiazinone (43) followed by conjugate addition reaction with a Normant reagent (cupper bromide dimethyl sulfide and 2benzyloxy-5-methyl phenylmagnesium bromide, 46) to create the conjugate addition product (47) with a new chiral center. This will then be subjected to hydrolysis to cleave off the chiral auxiliary and obtained the carboxylic acid (48). The carboxylic acid can then be taken through the Steglich reaction with diisopropylamine to obtain the intermediate 49 which will then be reduced and deprotected to obtain the tolterodine (45).

Scheme 7. Proposed pathway for tolterodine synthesis using the oxadiazinones as chiral templates.<smiles>CC1C(c2ccccc2)OC(=O)NN1C</smiles>

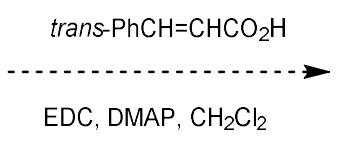<smiles>CC1C(c2ccccc2)OC(=O)N(C(=O)/C=C/c2ccccc2)N1C</smiles>

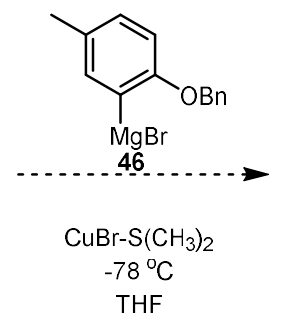

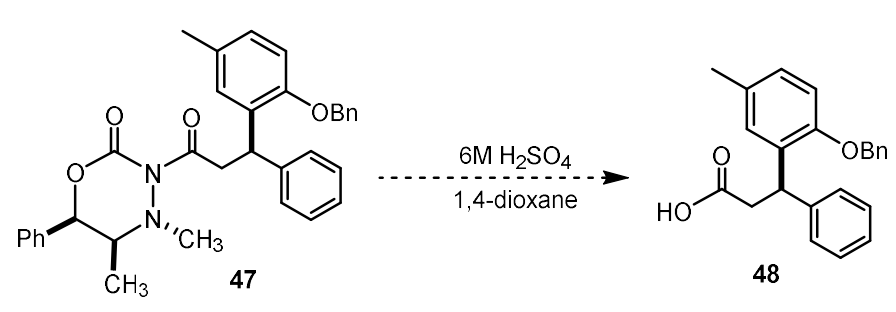

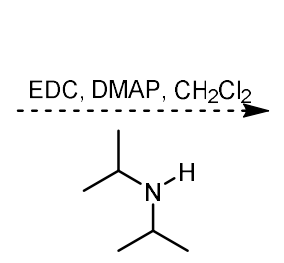<smiles>COc1ccc(C)cc1C(CC(=O)N(C(C)C)C(C)C)c1ccccc1</smiles><smiles>Cc1ccc(O)c(C(CCN(C(C)C)C(C)C)c2ccccc2)c1</smiles> 
In summary, this chapter has presented the importance of molecular chirality in bioactive molecules, and why it is important that medicinal agents are carefully evaluated for the properties of their enantiomers and racemic mixtures. Oxazolidinones have also been discussed as the mostly used chiral auxiliary in asymmetric synthesis to date. Likewise, the use of oxadiazinones as structurally novel chiral auxiliaries in the asymmetric aldol addition reaction have been discussed. The goal of this research is to apply these oxadiazinones in the synthesis of the medicinal agent tolterodine (Detrol), through asymmetric conjugate addition reaction. 


\section{CHAPTER II: OXADIAZINONES AS CHIRAL AUXILIARIES IN ASYMMETRIC}

\section{CONJUGATE ADDITION REACTIONS}

\section{Introduction}

As stated in Chapter I, the oxadiazinones have proven to be effective tools for conducting chiral auxiliary-directed asymmetric aldol addition reactions. The oxadiazinones that have been employed have relied primarily on the $\mathrm{N}_{4}$-substituent as the stereochemical control element leading to the observed diastereoselection in the asymmetric aldol addition reaction. This chapter explores the use of the chiral oxadiazinones in the process of asymmetric conjugate addition reactions (Figure 11). The oxadiazinones that will be presented in this chapter will also feature this $\mathrm{N}_{4}$-substituent as a key element of variation in the pursuit of the best possible diastereoselectivities (Figure 11).

Figure 11. Proposed oxadiazinone mediated asymmetric conjugate addition pathway.

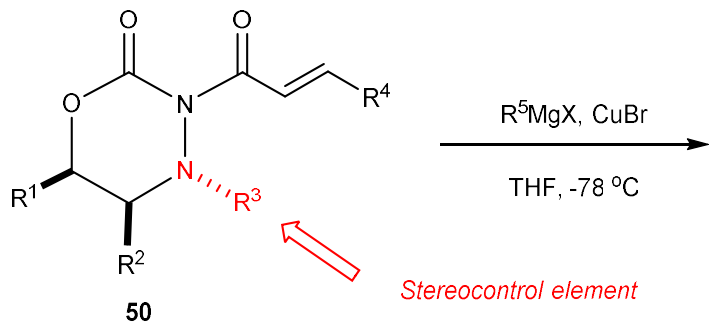

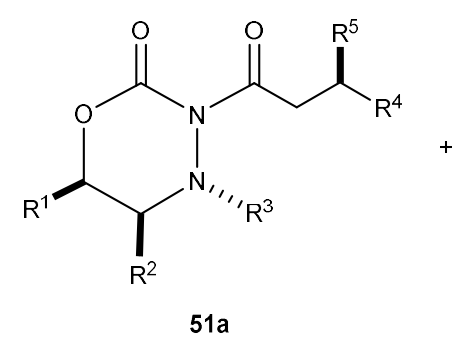

major diastereomer<smiles>[R]C([R])CC(=O)N1C(=O)OC([R])C([R])N1[R]</smiles>

$51 \mathrm{~b}$

minor diastereomer 


\section{Results and Discussion}

Ephedrine based oxadiazinones, synthesis, acylation and asymmetric conjugate addition

The conjugate addition project began with the same ephedrine based oxadiazinone that launched the asymmetric aldol addition project that was described in Chapter 1 . The $(1 R, 2 S)$ ephedrine based oxadiazinone (34) was synthesized in a three-step reaction: N-nitrosation, lithium aluminum hydride reduction, and cyclization (Scheme 8$)$. The $(1 R, 2 S)$-ephedrine (52) starting material was reacted with sodium nitrite $\left(\mathrm{NaNO}_{2}\right)$ in the presence of aqueous hydrochloric acid $(\mathrm{HCl}, 3 \mathrm{M})$ and tetrahydrofuran (THF) to give the $\mathrm{N}$-nitrosamine target (53a and 53b) as a mixture of $E$ - and $Z$-diastereomers in a yield of $95 \%$. The $(1 R, 2 S)$-ephedrine based $\mathrm{N}$-nitrosamine thus obtained was reacted with the reducing agent lithium aluminum hydride $\left(\mathrm{LiAlH}_{4}\right)$ using THF as solvent. This afforded the $(1 R, 2 S)$-ephedrine based hydrazine (54) in a 93\% yield. The hydrazine product was immediately taken through a cyclization reaction with carbonyldiimidazole (CDI) (55) in the presence of THF to give the target $(1 R, 2 S)$-ephedrine based oxadiazinone (34) as a white solid in a 74\% yield.

Scheme 8. Synthesis of $(1 R, 2 S)$-ephedrine based oxadiazinone 25.<smiles>C[C@H](NCl)[C@H](O)c1ccccc1</smiles>

52

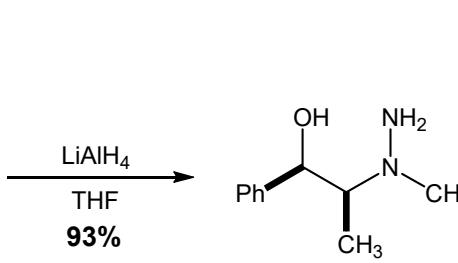

54<smiles>C[C@H]([C@H](O)c1ccccc1)N(C)N=O</smiles>

53b

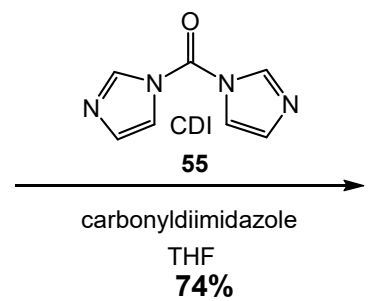

$74 \%$<smiles>C[C@H]1[C@H](c2ccccc2)OC(=O)NN1C</smiles>

34 
The mechanisms of these reactions are shown in Schemes 9-11. The N-nitrosation follows the standard pathway for the N-nitrosation of a secondary amine in which nitrous acid is generated in situ and reacted with the ephedrine substrate (Scheme 9). The lithium aluminum hydride reduction involves the formation of hydrogen gas as the initial step with subsequent attack of the hydride on the nitrosamine functional group (Scheme 10). The process ultimately yielded the desired ephedrine-based hydrazine. The hydrazine in turn reacted with carbonyldiimidazole through a series of nucleophilic addition/elimination pathways to form the target ephedrine based oxadiazinone. ${ }^{59}$

Scheme 9. The N-nitrosation reaction mechanism for the formation of compound $\mathbf{5 3}$.

Nitrous acid formation

$\mathrm{HCl}+\mathrm{NaNO}_{2} \rightleftharpoons \mathrm{HNO}_{2}+\mathrm{NaCl}$<smiles>O=[W]([O-])[O-]</smiles>
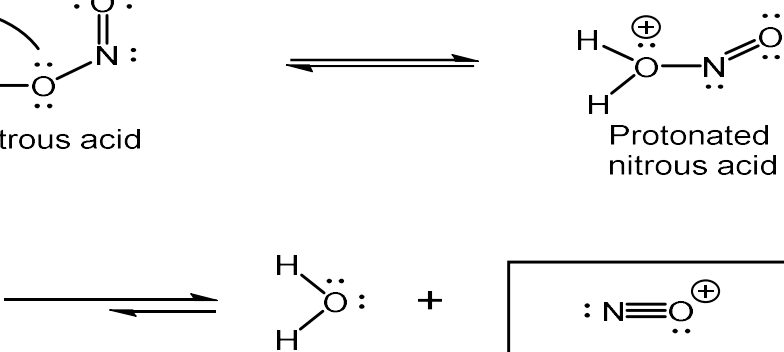

N-Nitrosation

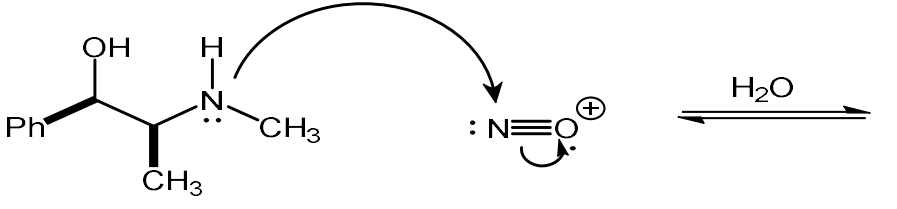

52<smiles>C[C@H]([C@H](O)c1ccccc1)N(C)N=O</smiles>

$53 a$<smiles>C[C@H]([C@H](O)c1ccccc1)N(C)N=O</smiles>

$53 b$ 
Scheme 10. The lithium aluminum hydride reduction reaction mechanism for the formation of compound 54.

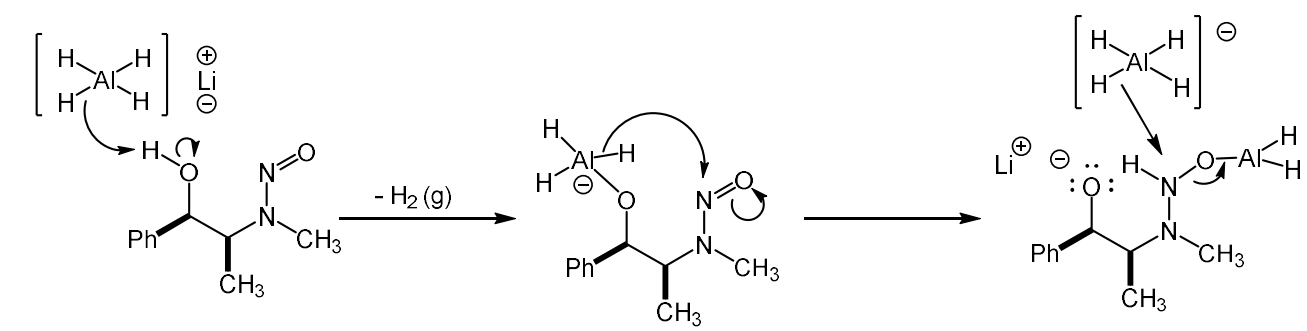

53

$54 a$

$54 b$

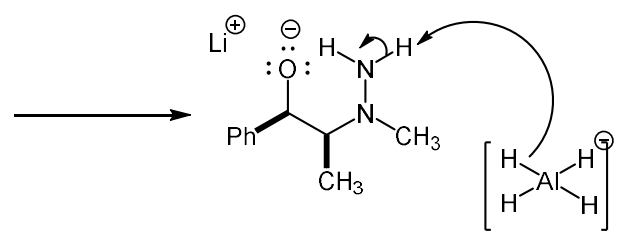

$54 c$

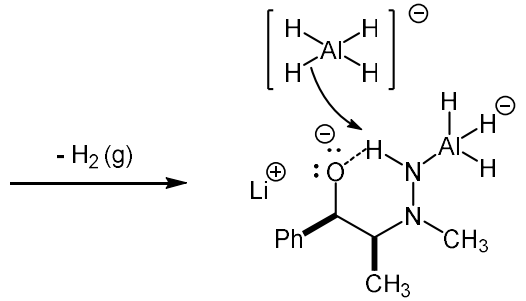

$54 d$

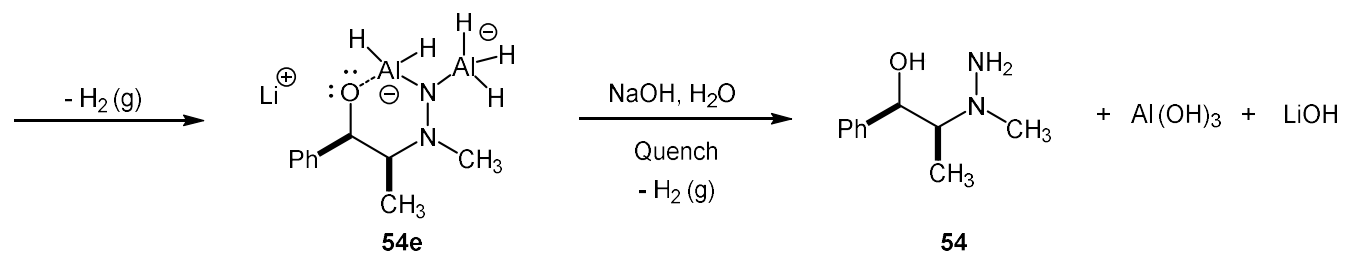

Scheme 11. The cyclization reaction mechanism for the formation of compound 34 .
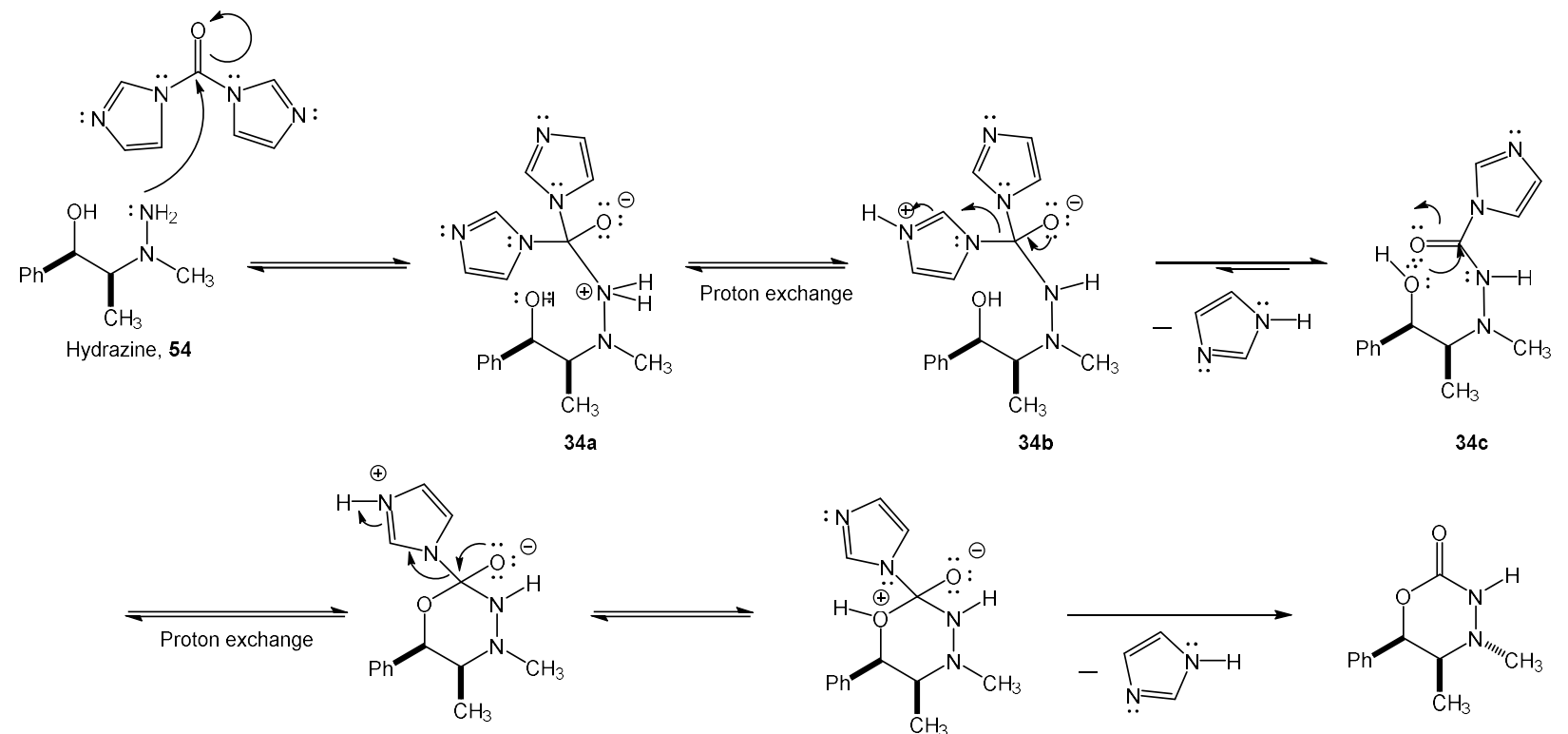

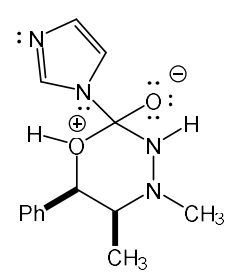

$34 \mathrm{e}$

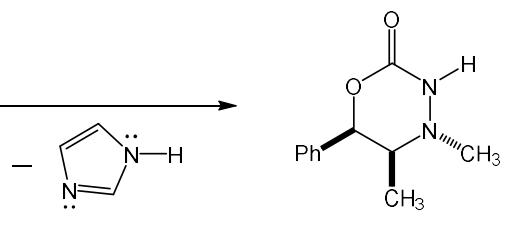

$(1 R, 2 S)$-ephedrine based oxadiazinone, 34 
The $(1 R, 2 S)$-ephedrine based oxadiazinone (34) thus obtained was acylated following the method of Steglich and coworkers, ${ }^{60}$ in which the heterocycle was reacted with trans-cinnamic acid (56) in the presence of 1-ethyl-3-(3-dimethylaminopropyl)carbodiimide (EDC) (57), and 4(dimethylamino)pyridine (DMAP) catalyst (58) to afford the $\mathrm{N}_{3}$-cinnamoyloxadiazinone (43) in a $71 \%$ yield after chromatography purification (Scheme 12). With this material in hand, the asymmetric conjugate addition reaction was carried out using the Normant conditions. ${ }^{61,62}$ Thus, the acylated oxadiazinone (43) was treated with a mixture of methylmagnesium bromide and copper bromide-dimethylsulfide complex to yield the conjugate addition product in a $65 \%$ isolated chemical yield after chromatographic purification. The reaction mechanisms for the acylation and conjugate addition reactions are shown in Schemes 13 and 14, respectively.

Scheme 12. Acylation and conjugate addition with the $(1 R, 2 S)$-ephedrine based oxadiazinone for the formation of compound $\mathbf{5 9}$.

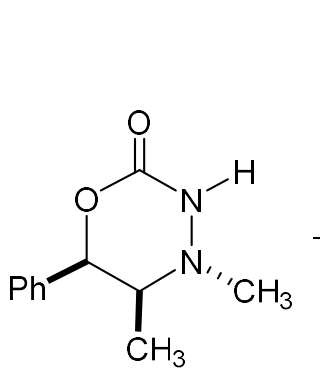

34

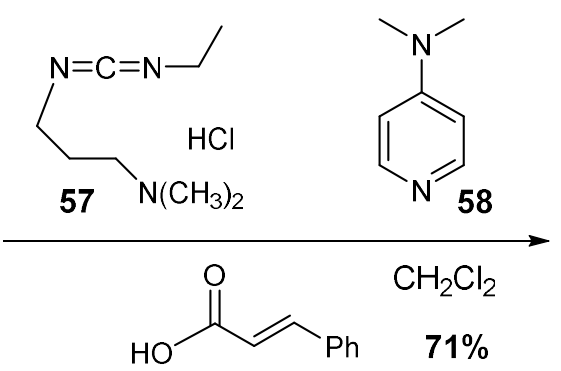

56<smiles>CC1C(c2ccccc2)OC(=O)N(C(=O)/C=C/c2ccccc2)N1C</smiles>

43<smiles>CC(CC(=O)N1C(=O)OC(c2ccccc2)C(C)N1C)C(=O)N1C(=O)OC(c2ccccc2)C(C)N1C</smiles> 
Scheme 13. Mechanism of reaction for the oxadiazinone acylation for the formation of compound 43.

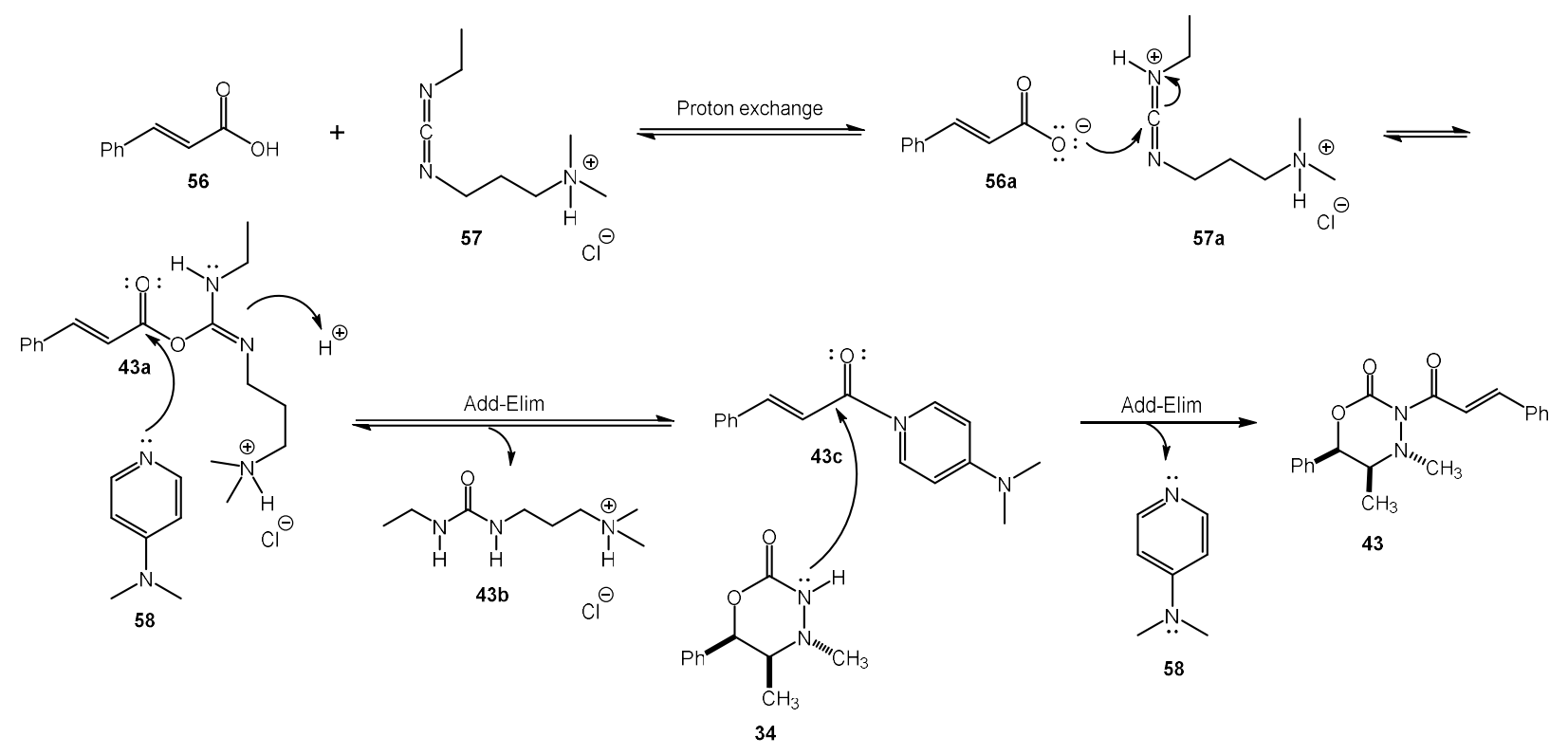

Scheme 14. Mechanism of reaction for the asymmetric conjugate addition reactions ${ }^{63,64}$ leading to the formation of compound $\mathbf{5 9}$.<smiles>CC1[C@H](c2ccccc2)OC(=O)N(C(=O)/C=C/c2ccccc2)N1C</smiles>

43<smiles>CC(CC(=O)N1C(=O)OC(c2ccccc2)C(C)N1C)c1ccccc1</smiles>

59

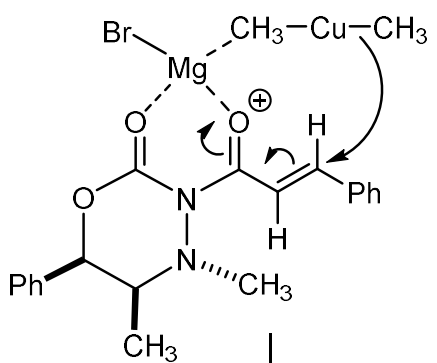

$43 a$

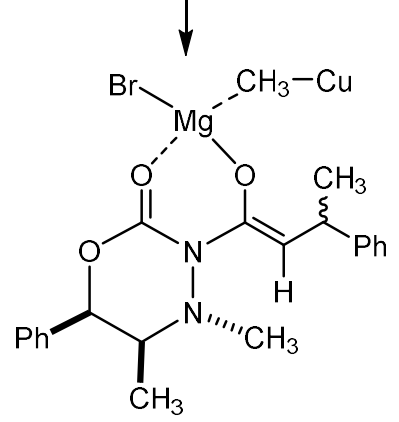

$43 b$ (enolate) 
This reaction generated a mixture of diastereomeric products $(59 \mathbf{a}$ and $59 \mathbf{b})$ in a ratio of 5.1:1 in favor of the major diastereomer as determined by $500 \mathrm{MHz}{ }^{1} \mathrm{H}$ NMR spectroscopy (Figure 12). The major diastereomer was tentatively assigned as the $(R)$-diastereomer (59a) based on the stereochemical orientation of the $\mathrm{N}_{4}$-methyl group.

Figure 12. $500 \mathrm{MHz}{ }^{1} \mathrm{H} \mathrm{NMR}$ spectrum of the conjugate addition product of $(1 R, 2 S)$-ephedrine based oxadiazinone.<smiles>[R]C(C)CC(=O)N1C(=O)O[C@@H](c2ccccc2)[C@H](C)N1C</smiles>

$59 a$
Predicted minor diastereomer<smiles>CC(CC(=O)N1C(=O)OC(c2ccccc2)C(C)N1C)c1ccccc1</smiles>

$59 b$

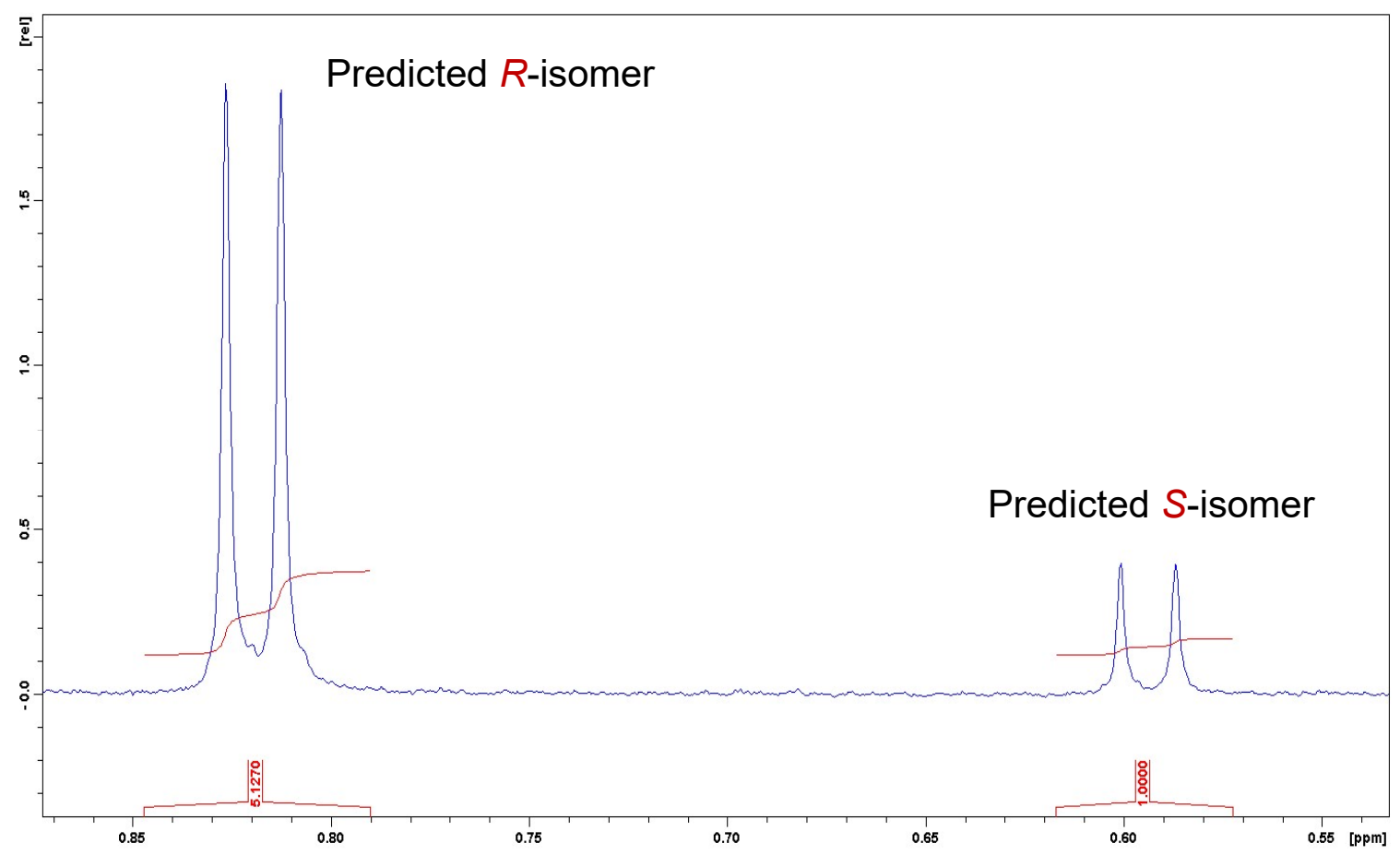


Stereochemistry determination of $(1 R, 2 S)$-ephedrine conjugate addition product through classical resolution

The stereochemistry of the diastereomeric products of the conjugate addition reaction with the $(1 R, 2 S)$-ephedrine based oxadiazinone was determined through the use of classical resolution (Scheme 15) ${ }^{65,66}$ This was accomplished by reacting 5.24 grams of racemic mixture of a commercially sourced 3-phenylbutyric acid (60a and 60b) with an enantiomerically pure chiral amine, $(S)-(-)$-phenylethylamine (61). This reaction generated a mixture of diastereomeric carboxylate salts (62a and 62b). The generated salts, being diastereomers, differ in their physical and chemical properties. Hence, one of the salts was very soluble in ethanol-water solution while the other salt readily formed fine long needles of white crystals. The crystals were recovered by vacuum filtration and subjected to a second recrystallization using ethanol and water.

The salt (62b) obtained from this process was subjected to extraction using aqueous hydrochloric acid (1M) and diethyl ether which aided the recovery of the single diastereomer of the phenyl butyric acid in a $48 \%$ isolated recovered yield. (Scheme 16). The optical rotation of the recovered acid was determined by polarimetric analysis to be $[\alpha]_{\mathrm{D}}=+43^{\circ}(75 \%$ ee). From the known compound (60a and $60 \mathbf{b})$, the $(R)$-isomer has a known optical rotation of $-57^{\circ}$ while the $S$-isomer has an optical rotation of $+57^{\circ}$. This suggests that the recovered carboxylic acid was the $S$-enantiomer of the butyric acid and that the salt that initially came out of the ethanol-water solution was the (S-amine, $S$-carboxylic acid)-diastereomer (62b). 
Scheme 15. Stereochemistry determination by classical resolution.

\section{Racemic Mixture (5.24 grams)}<smiles>CC(CC(=O)O)c1ccccc1</smiles>

(S)-(+)-3-phenylbutyric acid, 60a $[\alpha]_{D}=+57^{\circ}(c=1$, benzene $)$<smiles>CC(CC(=O)O)c1ccccc1</smiles>

(R)-(-)-3-phenylbutyric acid, 60b

$$
[\alpha]_{D}=-57^{\circ}(c=1, \text { benzene })
$$

salts formation ethanol, water

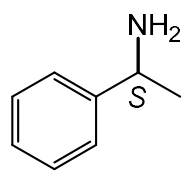

(S)-(-)-1-phenylethylamine, 61 3.90 grams

First recrystalization
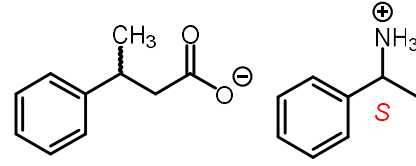

high solubility in ethanol/water $\mathbf{6 2 a}$

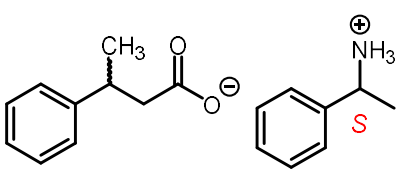

low solubility in ethanol/water. $\mathbf{6 2 b}$ Second Recrystalization, 3.15 grams 
Scheme 16. Stereochemistry determination: polarimetric analysis.

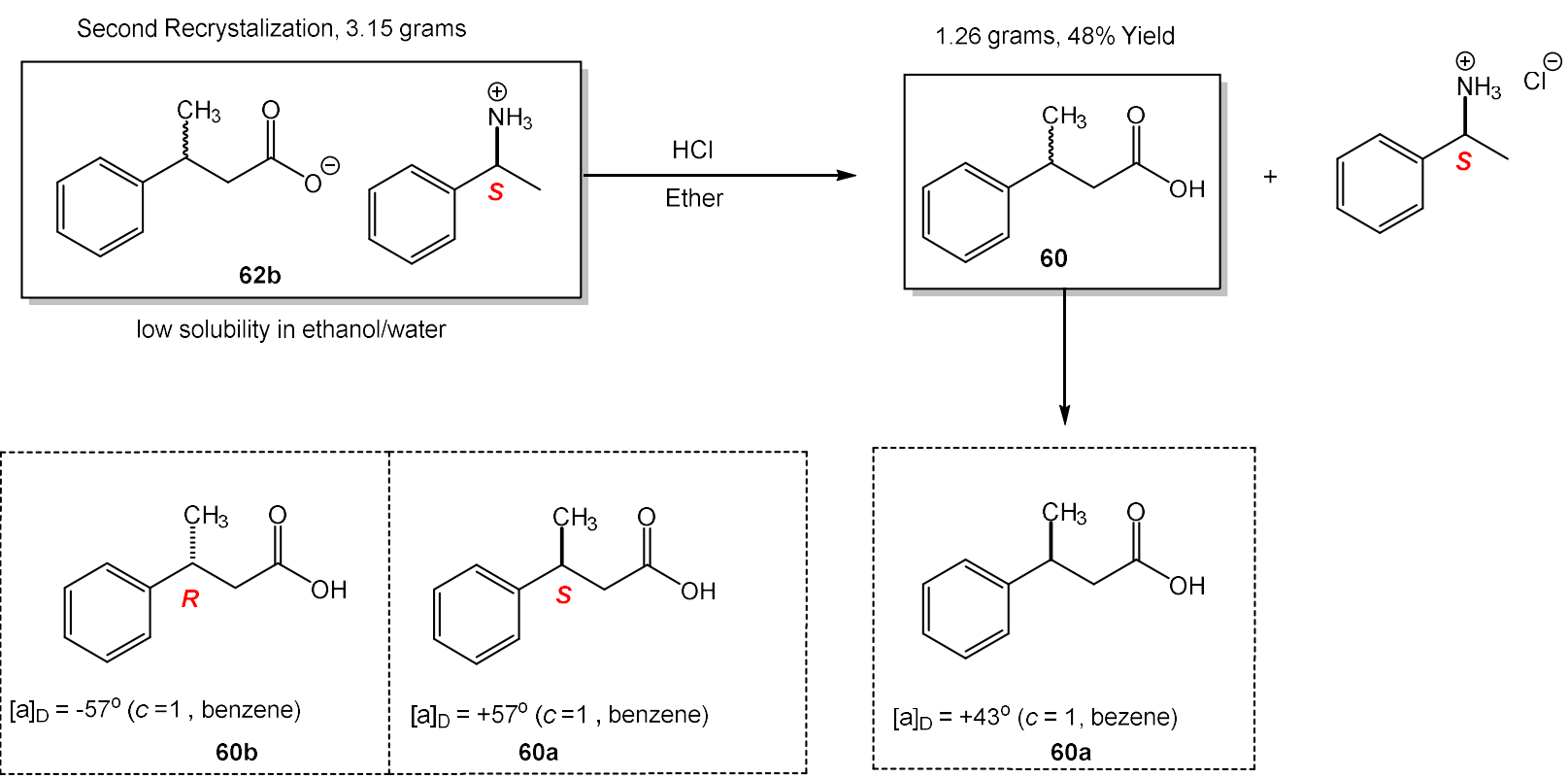

The $(S)-(+)-3-p h e n y l b u t y r i c$ acid (60a) obtained from the classical resolution was acylated with the $(1 R, 2 S)$-ephedrine based oxadiazinone (34) using the Steglich reaction conditions (Scheme 17). The acylated product (63) obtained was then analyzed by $500 \mathrm{MHz}{ }^{1} \mathrm{H}$ NMR spectroscopy. The obtained spectrum (Figure 13) was then compared with the $500 \mathrm{MHz}$ ${ }^{1} \mathrm{H}$ NMR spectrum obtained from the initial ephedrine based oxadiazinone directed conjugate addition reaction (Figure 14).

Scheme 17. Stereochemistry determination: Steglich reaction with the recovered butyric acid.<smiles>CC1C(c2ccccc2)OC(=O)NN1C</smiles>

34<smiles>CC(CC(=O)N1C(=O)OC(c2ccccc2)C(C)N1C)c1ccccc1</smiles>

$60 a$
63 
Figure 13. $500 \mathrm{MHz}{ }^{1} \mathrm{H} \mathrm{NMR}$ spectrum of the product of Steglich reaction between the $(1 R, 2 S)$ ephedrine based oxadiazinone and $(S)-(+)-3$-phenylbutyric acid (60a).

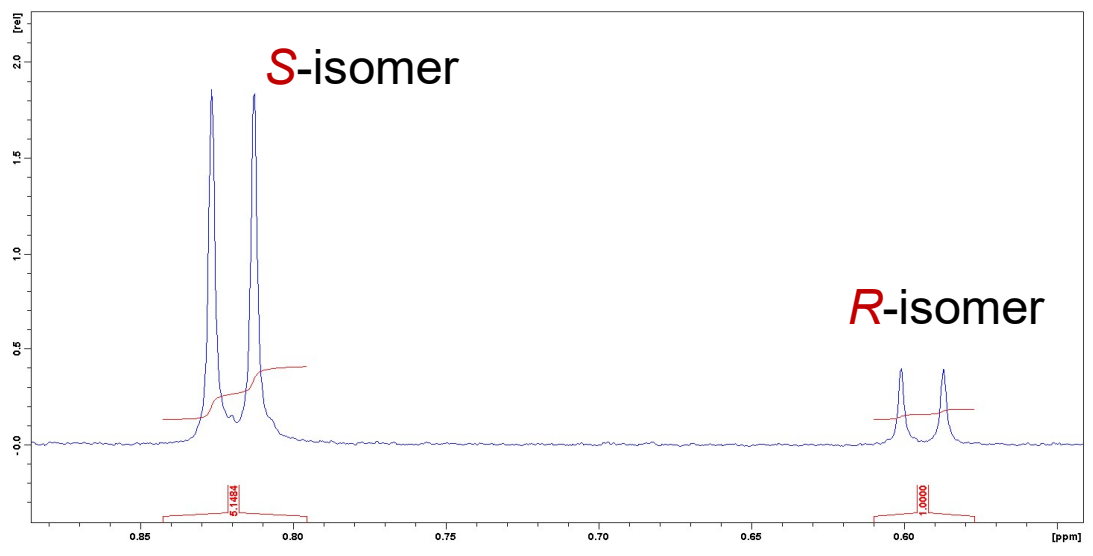

Figure 14. $500 \mathrm{MHz}{ }^{1} \mathrm{H} \mathrm{NMR}$ spectrum of the conjugate addition product of $(1 R, 2 S)$-ephedrine based oxadiazinone.

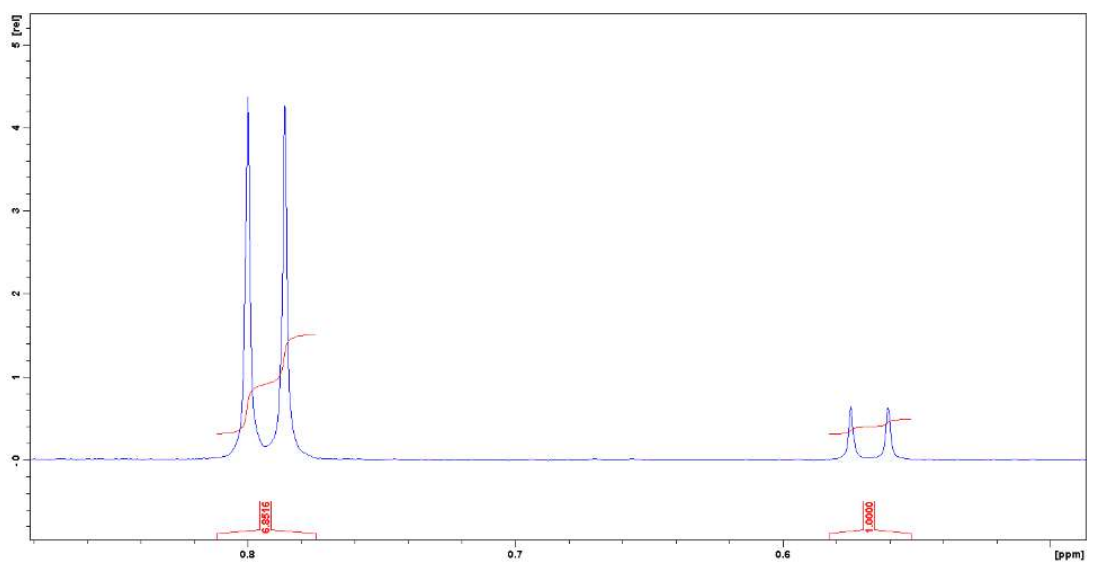

From the results obtained from the classical resolution, it became clear that the $(S)$-isomer was the major isomer! This was contrary to the initial prediction that the $(R)$-isomer was the major isomer. It then became essential to consider what could be the reason behind the $S$ isomer's domination in this reaction. 
Rationale to why the (S)-diastereomer was observed as the major isomer

Following the classical resolution results, a rationalization of the stereochemical outcome had to be made as the observed result was diametrically opposed to the predicted result. It is proposed that if the $\mathrm{N}_{3}$-acyl side chain is held in place as seen $(\mathbf{6 5})$, then the $(R)$-isomer is expected to be the dominant isomer. However, if there is a flexibility around the $\alpha$-carbon, such that the acyl side chain is rotated downward as shown (64), then the $(S)$-isomer becomes the dominant isomer. There may be other potential transition states that give rise to the observed stereochemical outcome. Ultimately, the diastereoselectivity observed for this system (5.1:1) is below the desired diastereoselectivity ratio desired for this work. As such, another family of the Ephedra alkaloid, namely (1S,2S)-pseudoephedrine, was considered.

Scheme 18. Rationale for the observed stereoselectivity in the ephedrine-based system.

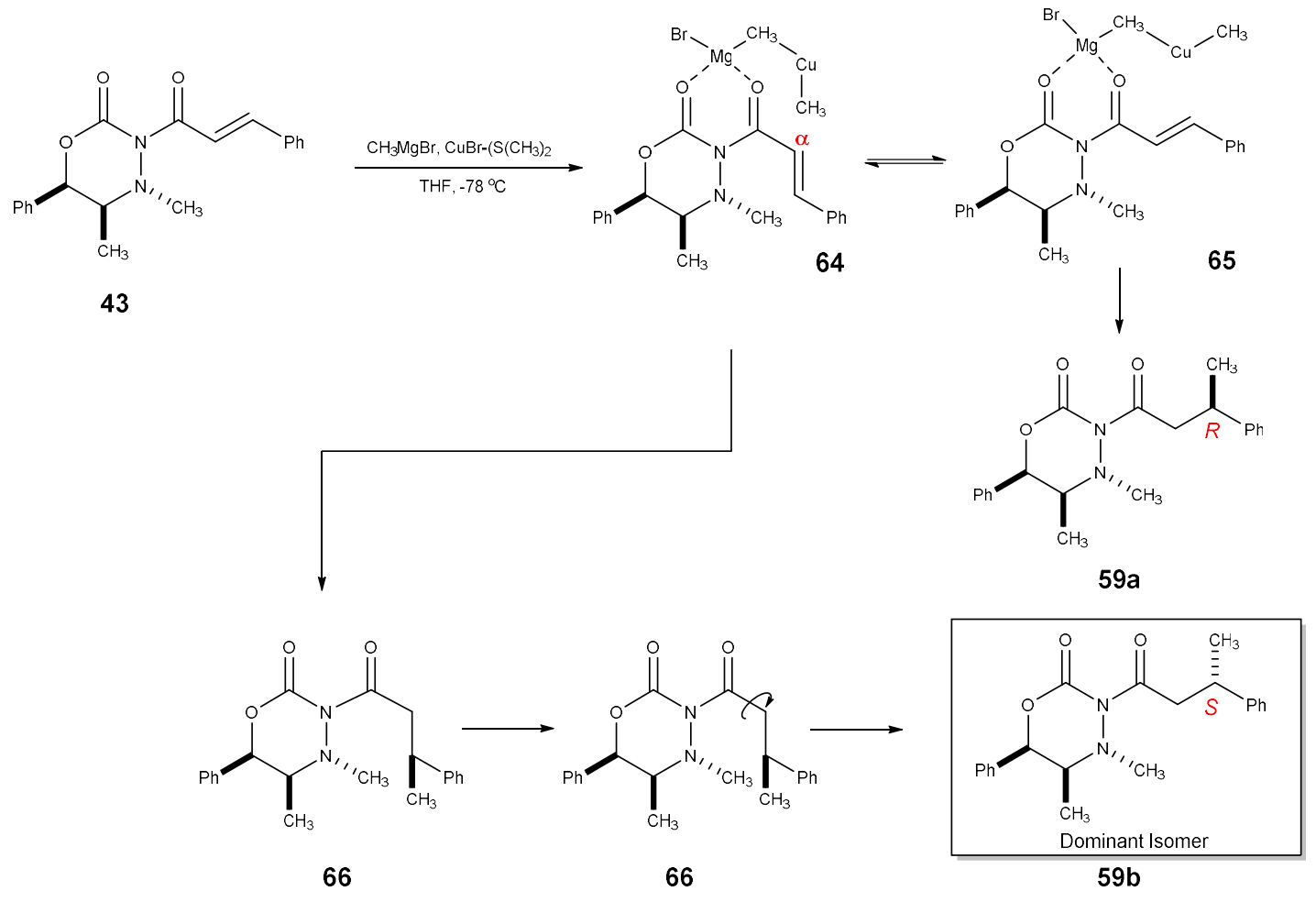


Pseudoephedrine based oxadiazinone, synthesis, acylation and asymmetric conjugate addition

In a bid to improve the diastereoselectivity of the oxadiazinones in asymmetric conjugate addition reaction, the $(1 S, 2 S)$-pseudoephedrine based oxadiazinone (70) was also examined. This oxadiazinone was synthesized by reacting the $(1 S, 2 S)$-pseudoephedrine substrate (67) with sodium nitrite in the presence of hydrochloric acid (3M) and tetrahydrofuran (THF) to give the $\mathrm{N}$-nitrosamine diastereomers (68a and $\mathbf{6 8 b}$ ) in near quantitative yield of 97\%. The N-nitrosamine product was then reacted with $\mathrm{LiAlH}_{4}$ in the presence of THF to afford the hydrazine (69) with a near quantitative yield of $99 \%$. The hydrazine was, in turn, reacted with cabonyldiimidazole to give the (1S,2S)-pseudoephedrine based heterocycle (70) in a 74\% yield (Scheme 19).

Scheme 19. Synthesis of the (1S,2S)-pseudoephedrine based oxadiazinone 70.

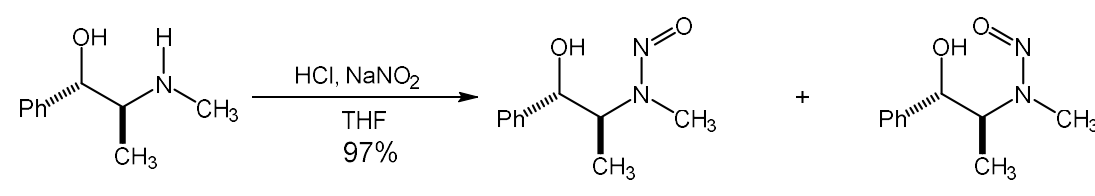

67

$68 a$

$68 b$

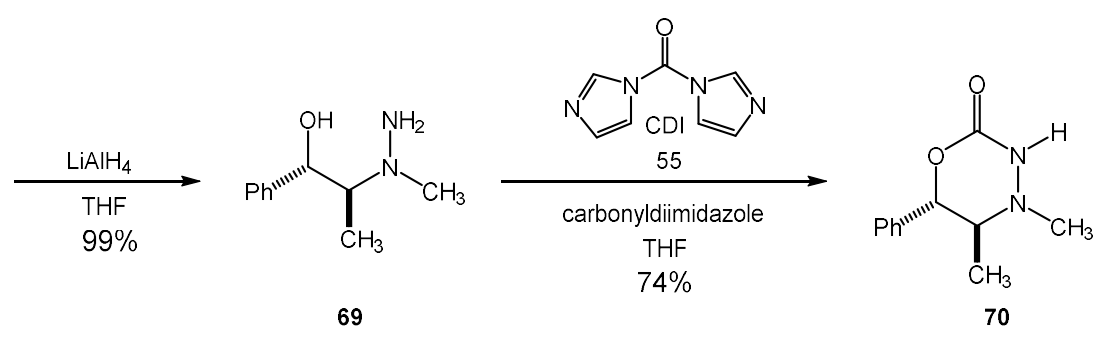

With the pseudoephedrine heterocycle (70) in hand, a Steglich reaction (Scheme 20) was conducted in which trans-cinnamic acid was coupled with the heterocycle using the coupling agent EDC and DMAP catalyst to afford the corresponding $\mathrm{N}_{3}$-trans-cinnamoyloxadiazinone (71) in a 59\% yield after chromatography purification. 
Scheme 20. Acylation of the $(1 S, 2 S)$-pseudoephedrine based oxadiazinone.<smiles>CC1[C@@H](c2ccccc2)N(Cc2ccccc2)C(=O)O[C@H]1c1ccccc1</smiles>

The purified $\mathrm{N}_{3}$-trans-cinnamoyloxadiazinone (71) was then subjected to Normant-

Grignard addition reaction (Scheme 21) to yield the corresponding $\mathrm{N}_{3}$-(3-methyl

hydrocinnamoyl) oxadiazinone as a mixture of diastereomers (72a and 72b) in a 79\% yield after chromatography.

Scheme 21. Asymmetric conjugation addition with the (1S,2S)-pseudoephedrine- $\mathrm{N}_{3}$ cinnamoyloxadiaxinone.<smiles>CC1[C@H](c2ccccc2)OC(=O)N(C(=O)/C=C/c2ccccc2)N1C</smiles>

71<smiles>C[C@H]1[C@@H](c2ccccc2)OC(=O)N(C(=O)C[C@@H](C)Pc2ccccc2)N1C</smiles>

$72 a$<smiles>CC(CC(=O)N1C(=O)O[C@H](c2ccccc2)C(C)N1C)c1ccccc1</smiles>

$72 \mathrm{~b}$

The diastereoselection ratio was determined by the use of $500 \mathrm{MHz}{ }^{1} \mathrm{H}$ NMR spectroscopy (Figure 15) to be 3.4:1, with the $R$-isomer (72a) assigned as the major diastereomer tentatively. 
Figure 15. $500 \mathrm{MHz}{ }^{1} \mathrm{H}$ NMR spectrum of the conjugate addition product of $(1 S, 2 S)$ -

pseudoephedrine system.

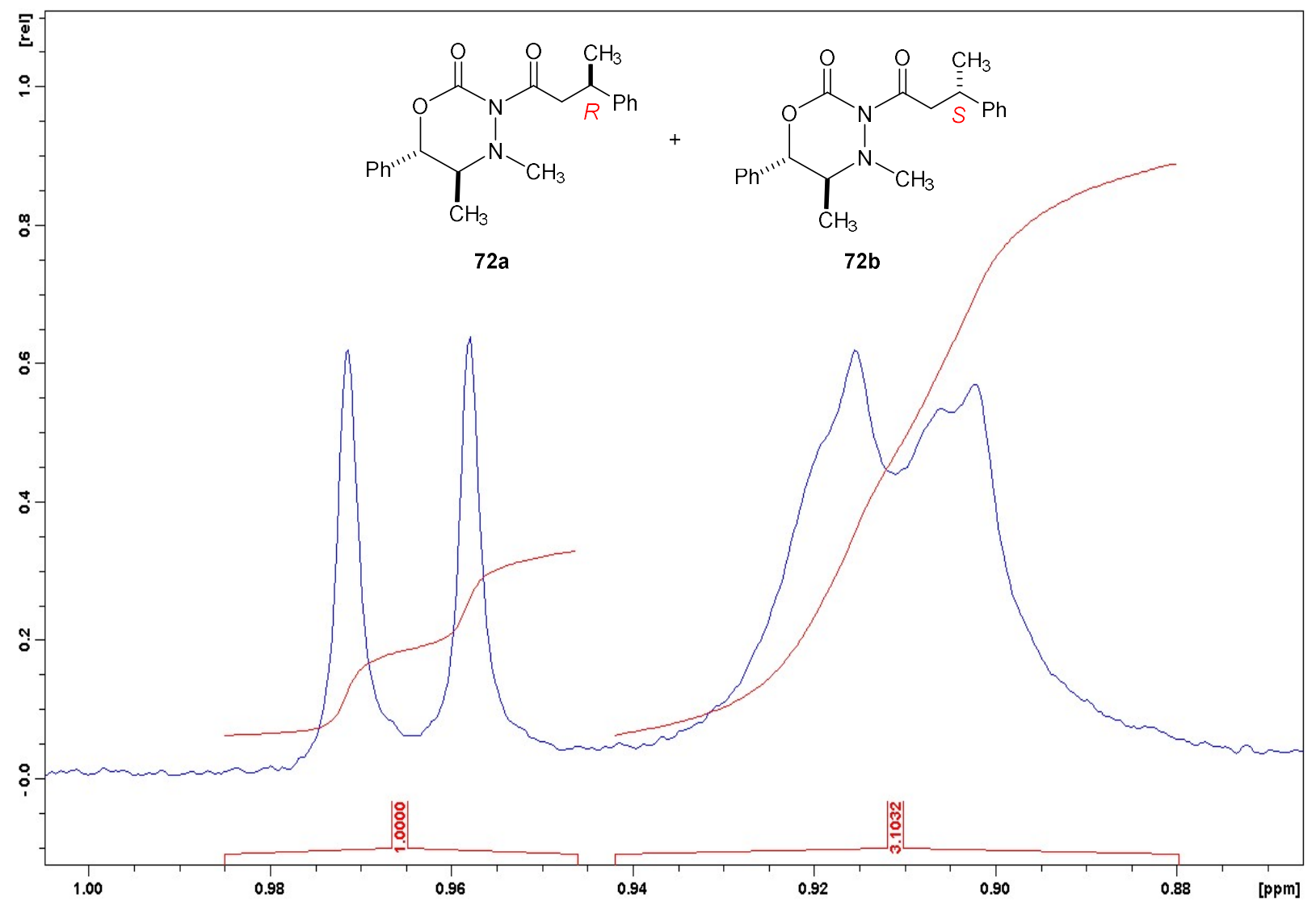

Apart from lower diastereoselectivity observed relative to the $(1 R, 2 S)$-ephedrine system, there was also a line broadening of one of the diagnostic peaks in the $500 \mathrm{MHz}{ }^{1} \mathrm{H} \mathrm{NMR}$ spectrum of the pseudoephedrine based oxadiazinone directed conjugate addition products (72a, b) (Figure 14). This led to a follow-up investigation of the starting material (71) for this reaction. A ${ }^{13} \mathrm{C}$ NMR spectral analysis was carried out on the acylated starting material for both the (1R,2S)-ephedrine based oxadiazinone (43) and the (1S,2S)-pseudoephedrine based oxadiazinone (71). The spectra obtained for the two compounds (Figure 16), suggested that the ephedrinebased compound (43) is conformationally rigid while the pseudoephedrine-based system (71) in 
conformationally flexible, which could be the reason for the lower diastereoselectivity observed in relation to the ephedrine-based system.

Figure 16. $125 \mathrm{MHz}{ }^{13} \mathrm{C}$ NMR spectra comparing the conformational rigidity of the ephedrine based oxadiazinone (43, top) and the pseudoephedrine based oxadiazinone (71, bottom) systems.

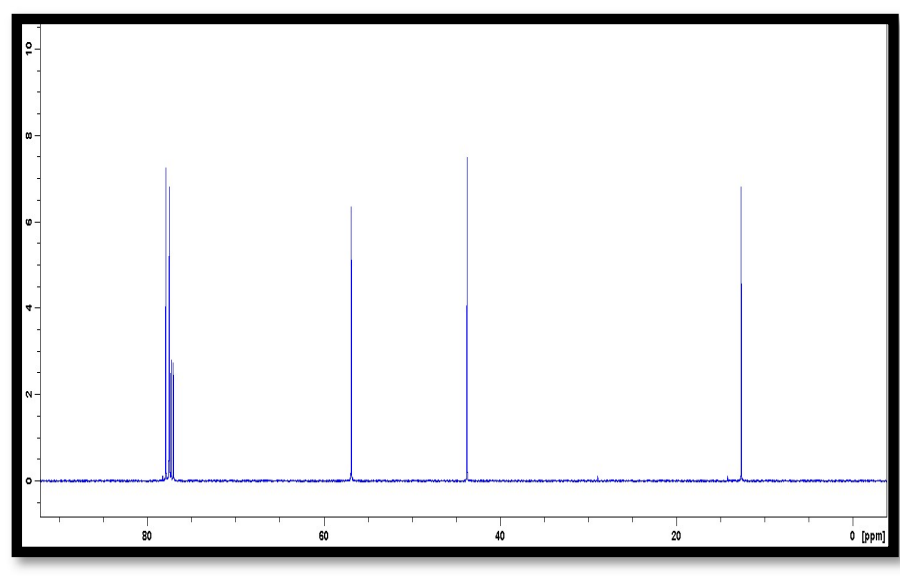<smiles>CC1C(c2ccccc2)OC(=O)N(C(=O)/C=C/c2ccccc2)N1C</smiles>

Conformationally stable
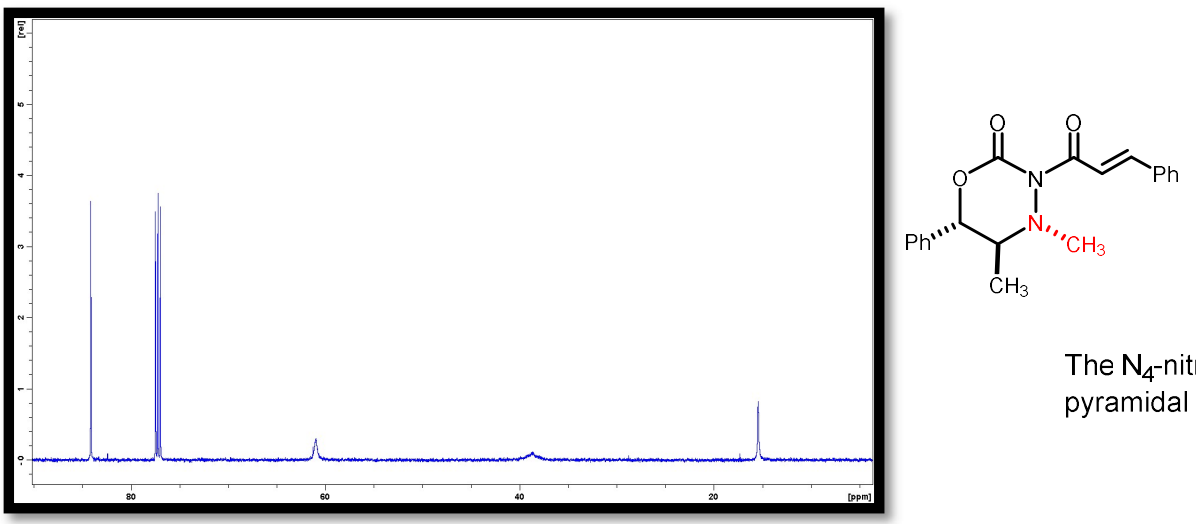<smiles>CC1[C@H](P)OC(=O)N(C(=O)/C=C/c2ccccc2)N1C</smiles>

The $\mathrm{N}_{4}$-nitrogen is undergoing pyramidal inversion.

As a result of the low diastereoselectivity and the conformational flexibilities exhibited by the pseudoephedrine-based system, another member of the Ephedra family, the $(1 R, 2 S)$ norephedrine based $\mathrm{N}_{4}$-para-methoxybenzyloxadiazinone was also considered. It was projected that the larger group at the $\mathrm{N}_{4}$-position would significantly improve the diastereoselectivity of the oxadiazinone. 
In pursuit of an improved diastereoselectivity in the asymmetric conjugate addition synthesis, a norephedrine based oxadiazinone (73) was also employed (Figure 17). In this case, the $\mathrm{N}_{4}$-substituent (stereochemical control element) would be a para-methoxybenzyl (PMB) group, a group that was believed would aid in improving diastereoselectivity due to its larger steric demand compared to the $\mathrm{N}_{4}$-methyl group. This para-methoxy-benzyl- substituted oxadiazinone was synthesized from the $(1 R, 2 S)$-norephedrine precursor (74) (Figure 18).

Figure 17. The Ephedra based oxadiazinones.<smiles>CC1C(c2ccccc2)OC(=O)NN1C</smiles>

$(1 R, 2 S)$-ephedine-based oxadiazinone, 34 vs.<smiles>CC1C(c2ccccc2)OC(=O)NN1C</smiles>

(1S,2S)-pseudoephedine-based oxadiazinone, 70

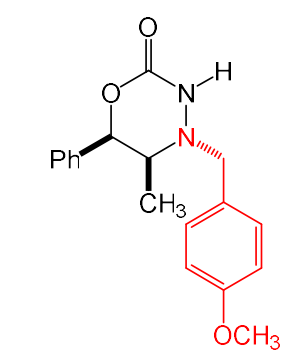

$(1 R, 2 S)$-norephedine based oxadiazinone, 73

Figure 18. The Ephedra alkaloids as the key starting materials for the formation of the oxadiazinones.

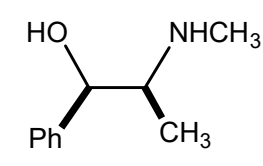

(1R,2S)-ephedrine, 52 vs.<smiles>CN[C@@H](C)[C@H](O)[PbH]</smiles>

(1S,2S)-pseudoephedrine, 67 vs.

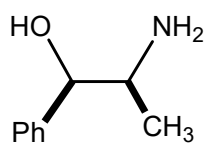

(1R,2S)-norephedrine, 74 
The synthesis follows similar reaction pathway as the ephedrine and pseudoephedrinebased systems (Scheme 22). However, prior to the N-nitrosation reaction, the $(1 R, 2 S)$ norephedrine was subjected to reductive amination with para-methoxybenzaldehyde (74) in the presence of ethanol absolute to introduce the -PMB group. The reaction was later brought to completion through the addition of sodium borohydride $\left(\mathrm{NaBH}_{4}\right)$ as shown the reaction mechanism (Scheme 23) leading to the formation of the amino alcohol (75). Without further purification, the $\alpha$-amino alcohol was immediately converted to the corresponding $\mathrm{N}$-nitrosamine (76) in a $95 \%$ yield through reaction with sodium nitrite in the presence of aqueous $\mathrm{HCl}(3 \mathrm{M})$ and THF. With the N-nitrosamine in hand, a lithium aluminum hydride $\left(\mathrm{LiAlH}_{4}\right)$ reduction was carried out using THF as the solvent. This led to the isolation of the corresponding hydrazine (77) in a $90 \%$ yield. The hydrazine was then reacted with carbonyldiimidazole using THF as solvent. This yielded the $(1 R, 2 S)$-norephedrine based $\mathrm{N}_{4}-p$-methoxybenzyl oxadiazinone (73) in a $47 \%$ yield.

Scheme 22. Synthesis of the $(1 R, 2 S)$-norephedrine- $\mathrm{N}_{4}-p$-methoxybenzyl oxadiazinone, $\mathbf{7 3}$

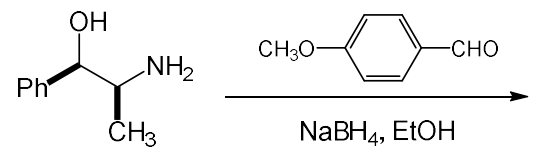

74

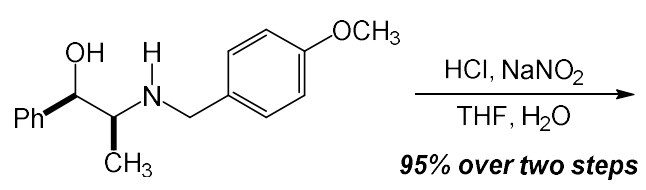

75

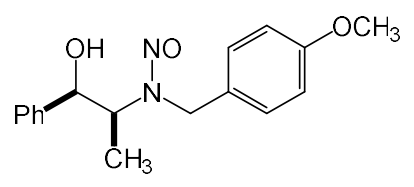

76<smiles>COc1ccc(CN(N)[C@@H](C)C(O)[C@H](C)N(N)Cc2ccc(OC)cc2)cc1</smiles> 
Scheme 23. Reductive amination reaction mechanism for the formation of $\mathrm{N}_{4}-p$-methoxybenzyl amino alcohol, 75.

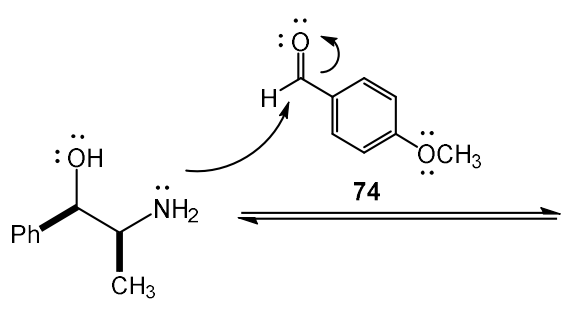

$(1 R, 2 S)$-norephedrine, 52

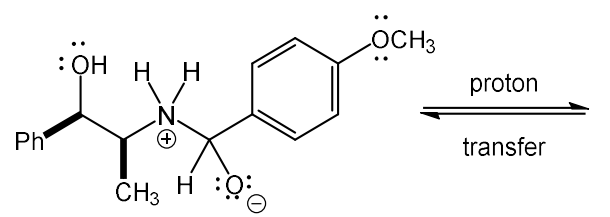

$75 \mathrm{a}$

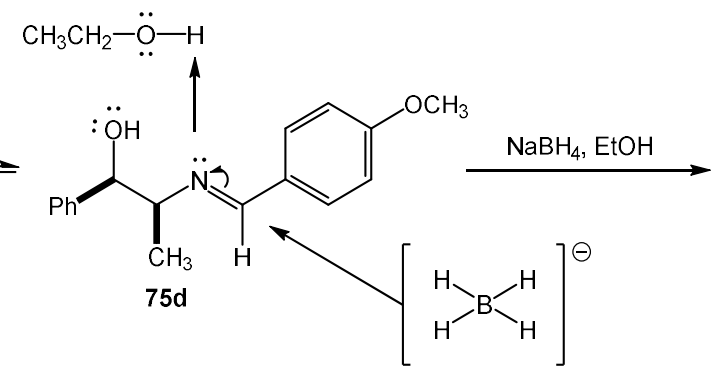

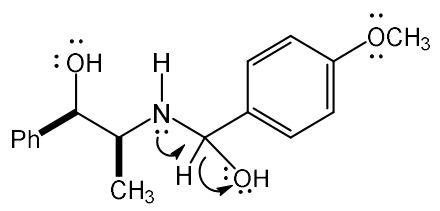

$75 b$<smiles>COc1ccc(CN(C)C(C)C(O)c2ccccc2)cc1</smiles>

To determine if the steric volume of the incoming group would have an impact on the diastereoselectivities of the conjugate addition reactions, the para-methoxybenzyl oxadiazinone (73) was taken through two different acylation pathways (Scheme 24). In the first reaction (Scheme 24a), the heterocycle was acylated with trans-cinnamic acid using the Steglich reaction conditions to give the $(1 R, 2 S)$-norephedrine based $\mathrm{N}_{4}-p$-methoxybenzyl- $\mathrm{N}_{3}$-cinnamoyl oxadiazinone (78) in an $80 \%$ yield. In this case, methyl magnesium bromide $\left(\mathrm{CH}_{3} \mathrm{MgBr}\right)$ would be employed as the Grignard reagent for the conjugate addition reaction. In the second reaction pathway (Scheme 24b), on the other hand, the heterocycle was acylated with transcrotonylchloride (79) in the presence of sodium hydride $(\mathrm{NaH})$ base and THF to yield the $(1 R, 2 S)$-norephedrine based $\mathrm{N}_{4}-p$-methoxybenzyl-N $\mathrm{N}_{3}$-crotonyl oxadiazinone (80) in a $51 \%$ yield. 
Here, the conjugate addition reaction would be conducted using phenyl magnesium bromide $(\mathrm{PhMgBr})$ as the Grignard reagent.

Scheme 24. Acylation reactions with the $(1 R, 2 S)$-norephedrine based oxadiazinone using (a) trans cinnamic acid and (b) trans-crotonyl chloride, for the formation of the acylated products $\mathbf{7 8}$ and $\mathbf{8 0}$.

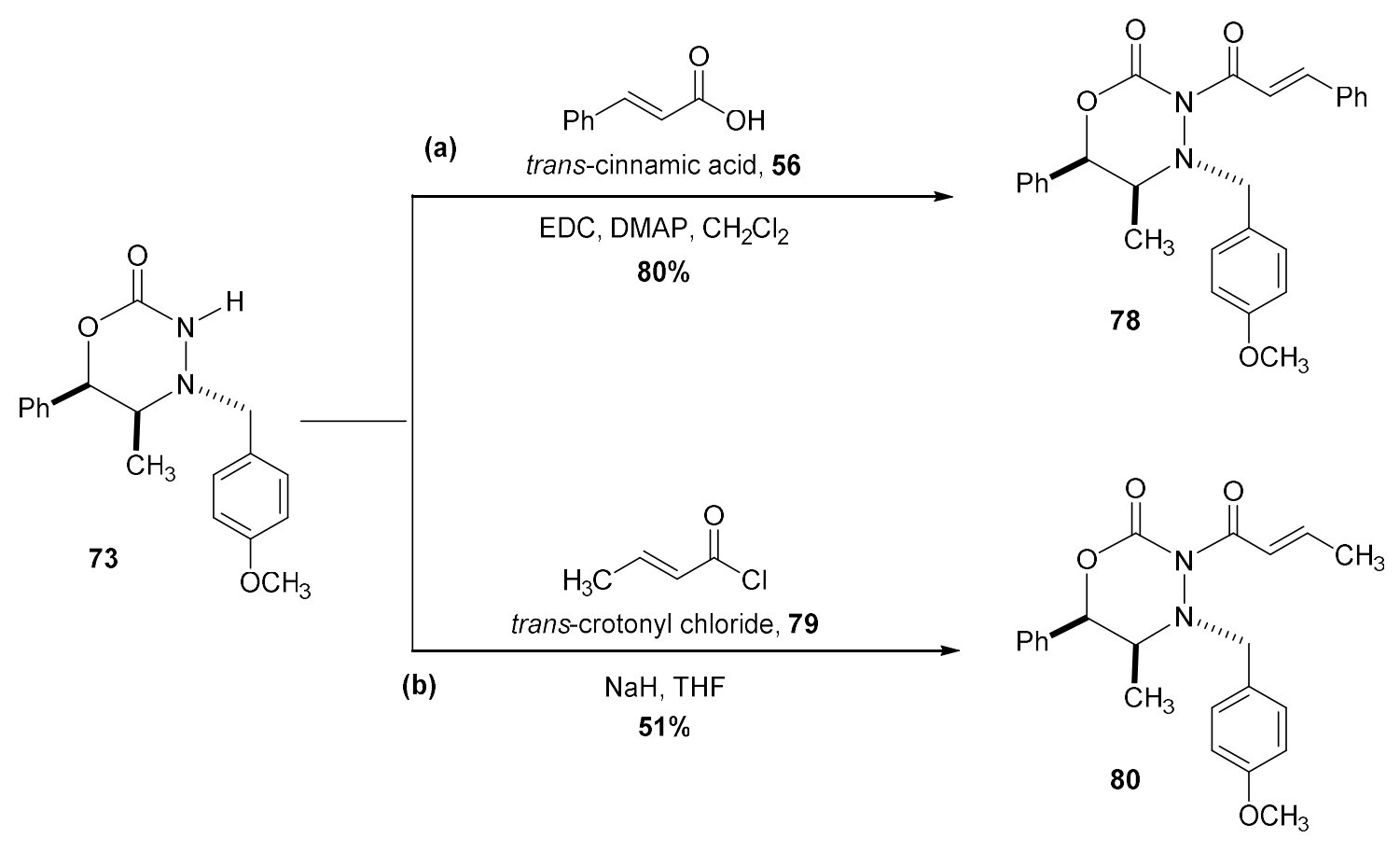

With the acylated products in hand, the $(1 R, 2 S)$-norephedrine based $\mathrm{N}_{4}-p$ methoxybenzyl- $\mathrm{N}_{3}$-cinnamoyl oxadiazinone (78) was taken through asymmetric conjugate addition reaction (Scheme 25) using copper bromide dimethyl sulfide $\left(\mathrm{CuBr} \cdot \mathrm{S}\left(\mathrm{CH}_{3}\right)_{2}\right)$ and methyl magnesium bromide $\left(\mathrm{CH}_{3} \mathrm{MgBr}\right)$ (the Normant reagent) to give the conjugate addition product (81) as a mixture of diastereomers (81a \& 81b) in a 62\% yield. In this case, a methyl group was added to the unsaturated side chain to create a new chiral center. 
Scheme 25. Asymmetric conjugation addition in the formation of compound $\mathbf{8 1}$.
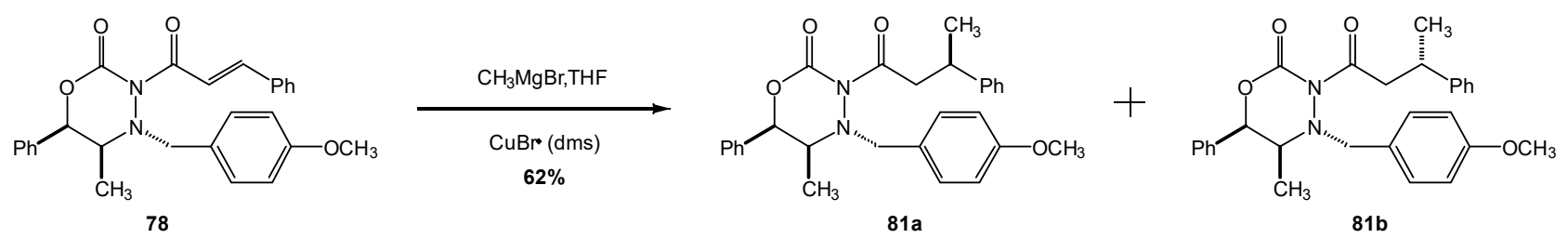

Scheme 26. Asymmetric conjugation addition in the formation of compound $\mathbf{8 2}$.

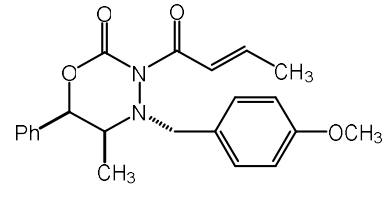

80

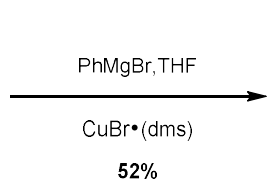

$52 \%$

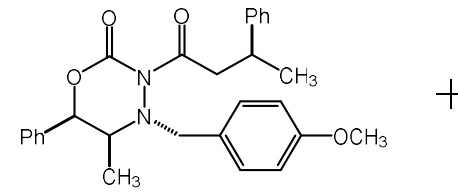

$82 a$

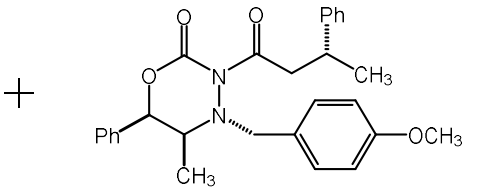

$82 b$

Likewise, the $(1 R, 2 S)$-norephedrine- $\mathrm{N}_{4}-p$-methoxybenzyl- $\mathrm{N}_{3}$-crotonyloxadiazinone $(\mathbf{8 0})$ was subjected to an asymmetric conjugate addition reaction (Scheme 26) using copper bromide dimethyl sulfide $\left(\mathrm{CuBr} \cdot \mathrm{S}\left(\mathrm{CH}_{3}\right)_{2}\right)$ and phenyl magnesium bromide $(\mathrm{PhMgBr})$ to give the conjugate addition product (82) as a mixture of diastereomers (82a and $\mathbf{8 2 b}$ ) in a $52 \%$ yield. Here, the incoming group added to the unsaturated side chain was the more sterically demanding phenyl group. Both conjugate addition products (81 and $\mathbf{8 2}$ ) were analyzed by $500 \mathrm{MHz}$ proton NMR spectroscopy.

The (1R,2S)-norephedrine-N $4-p$-methoxybenzyl-N $3-(3-$ phenylbutanoyl) (81) gave a diastereomeric ratio of 2.9:1 in favor of the major diastereomer (Figure 19). The $(1 R, 2 S)$ norephedrine based $\mathrm{N}_{4}-p$-methoxybenzyl- $\mathrm{N}_{3}$-(3-phenylbutanoyl) (82) also gave a diastereomeric ratio of 2.9:1 in favor of the major diastereomer (Figure 20). This implies that the steric volume of the incoming group has no direct impact on the stereoselectivities of the asymmetric conjugate addition reactions. 
Figure 19. $500 \mathrm{MHz}{ }^{1} \mathrm{H}$ NMR spectrum of the $(1 R, 2 S)$-norephedrine based $\mathrm{N}_{4}-p$ methoxybenzyl-N $\mathrm{N}_{3}-(3-$ phenylbutanoyl) oxadiazinone (81).

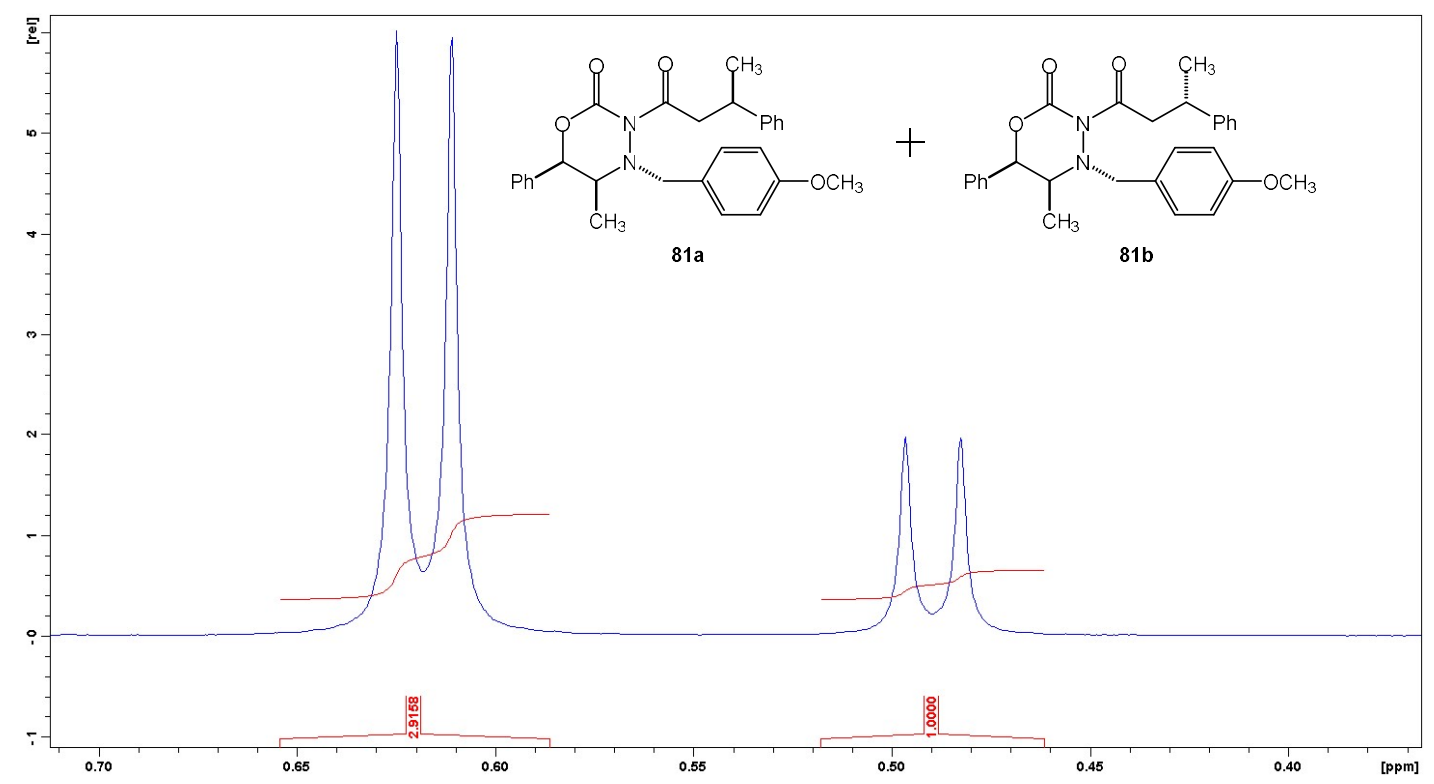

Figure 20. $500 \mathrm{MHz}{ }^{1} \mathrm{H}$ NMR spectrum of the $(1 R, 2 S)$-norephedrine based $\mathrm{N}_{4-}-p$ methoxybenzyl-N3-(3-phenylbutanoyl) oxadiazinone (82).

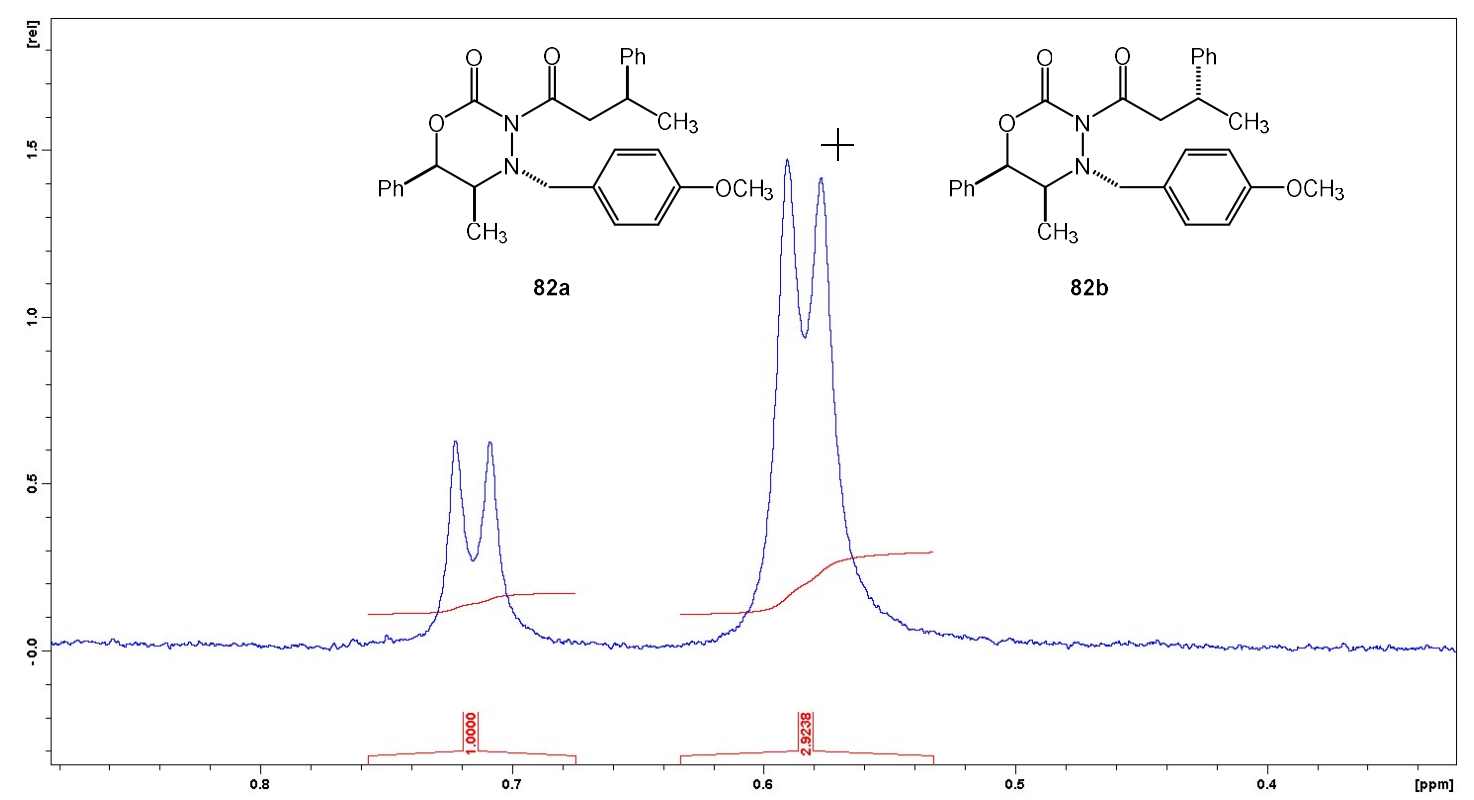


Based on the stereochemical orientation of the $\mathrm{N}_{4}-p$-methoxybenzyl group (the stereochemical control element), the $(R)$-isomer (81a) was assigned the major diastereomer in the case of the cinnamoyl system while the $(S)$-isomer (82a) was assigned the major diastereomer in the case of the crotonyl system.

Stereochemistry determination of $(1 R, 2 S)$-norephedrine conjugate addition product through hydrolysis

To establish the stereochemical orientation of the major and minor isomers of the norephedrine system, the addition product (81) was subjected to oxidative hydrolysis using ceric ammonium nitrate $\left(\mathrm{Ce}\left(\mathrm{NH}_{4}\right)_{2}\left(\mathrm{NO}_{3}\right)_{6}\right.$ and acetonitrile $\left(\mathrm{CH}_{3} \mathrm{CN}\right)$ in an aqueous medium to recover the acyl side chain of the conjugate addition products (Scheme 27).

Scheme 27. The norephedrine stereochemistry determination by hydrolysis and polarimetric analysis.<smiles>COc1ccc(CN2C(C)C(c3ccccc3)CC(=O)N2C(=O)CC(C)c2ccccc2)cc1</smiles><smiles>COc1ccc(CN2C(C)C(c3ccccc3)OC(=O)N2C(=O)CC(C)c2ccccc2)cc1</smiles><smiles></smiles>
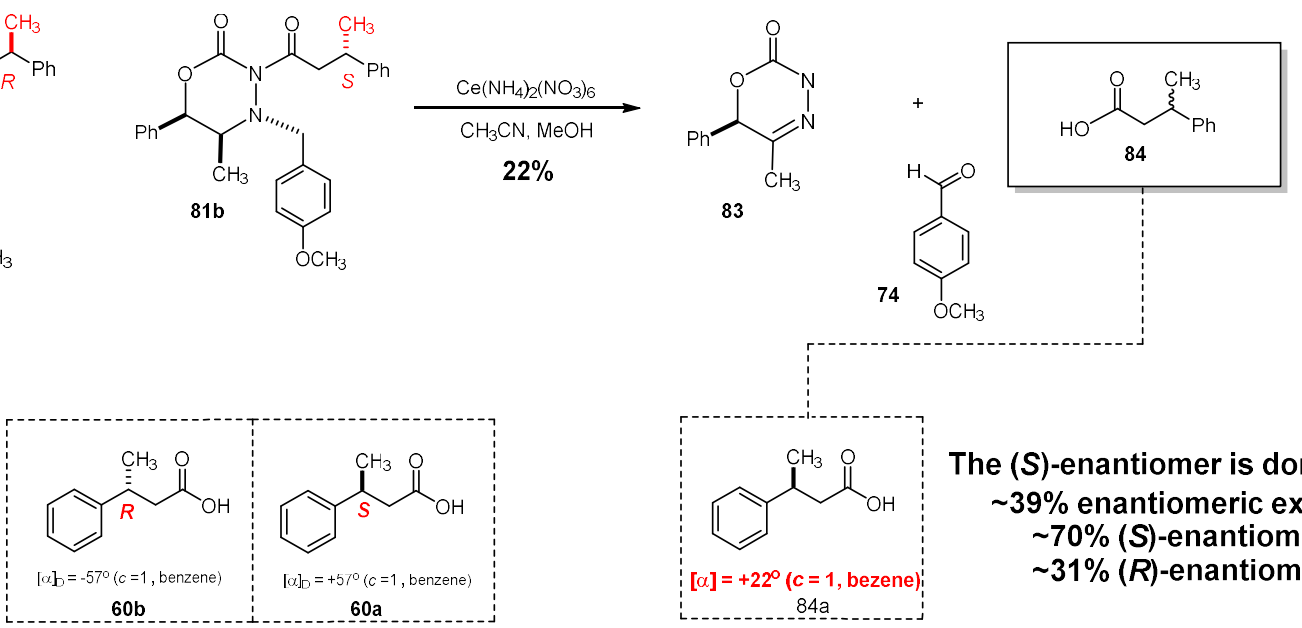

The (S)-enantiomer is dominant $\sim 39 \%$ enantiomeric excess $\sim 70 \%$ (S)-enantiomer $\sim 31 \%(R)$-enantiomer 
The phenyl butyric acid side chain (84) was isolated from this reaction in a $22 \%$ yield after chromatography purification. The recovered acid was then taken through polarimetric analysis giving an optical rotation of $+22^{\circ}(39 \%$ ee), suggesting that the $(S)$-isomer is also the major isomer in this case, contrary to the predicted $R$-isomer.

Rationale for the low diastereoselectivities and stereochemical orientation of the major isomer

As stated earlier, just as in the case of the ephedrine based oxadiazinone (59), the major isomer for the norephedrine-based system turned out to be the $(S)$-isomer as against the $(R)$ isomer which was predicted based on the stereochemical orientation of the $\mathrm{N}_{4}$-paramethoxybenzyl group. To rationalize this observation, the acylated starting material (78) was analyzed by $125 \mathrm{MHz}{ }^{13} \mathrm{C}$ NMR (Figure 21). The analysis suggested that the acylated starting material is conformationally rigid. This was evident in the distinct peaks present in the alkyl carbon region of the spectrum contrary to peaks distortions observed in this region in the pseudoephedrine-based system. 
Figure 21. Investigation of conformational rigidity of the norephedrine based system by 125 $\mathrm{MHz}{ }^{13} \mathrm{C}$ NMR.<smiles></smiles><smiles>C=CC1C=CC=C1</smiles><smiles>COc1ccc(CN2C(C)C(c3ccccc3)OC(=O)N2C(=O)/C=C/c2ccccc2)cc1</smiles>

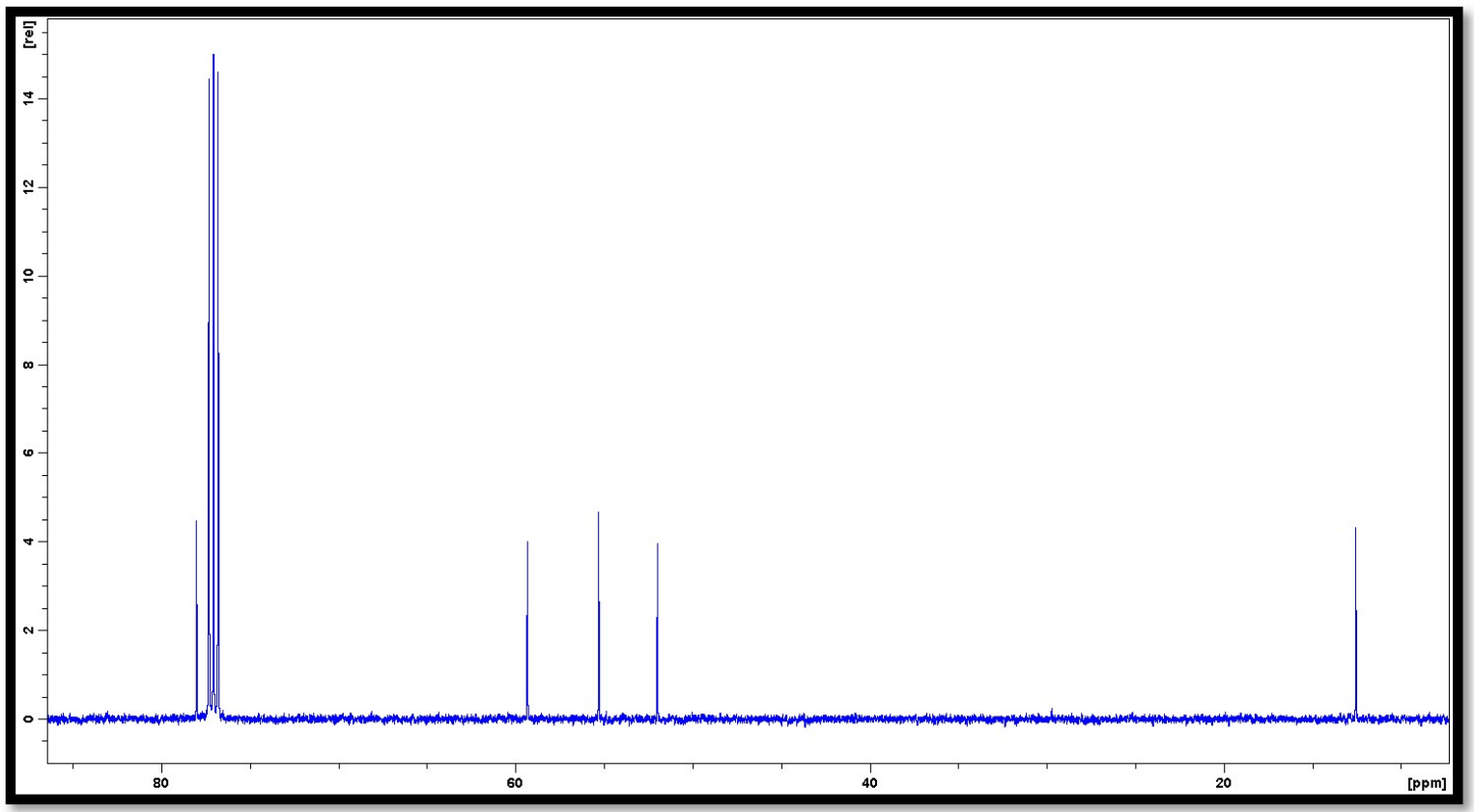

This observation suggested that the pyramidal inversion observed in the case of the pseudoephedrine (Figure 16) is not relevant in the case of this norephedrine-based oxadiazinone. The explanation that could possibly be given for the low diastereoselectivity observed for this system therefore, is a possible conformational flexibility of the acyl side chain in the molecule (Figure 22). 
Figure 22. Rationale for the observed stereoselectivity in the norephedrine based system.<smiles>C[M]OC(=O)N1C(=O)OC(c2ccccc2)C(C)N1Cc1ccc(OC)cc1</smiles><smiles>C=CC(C)(Br)O[W](=O)C(=Cc1ccccc1)N1C(=O)OC(c2ccccc2)C(C)N1[C@H](Cc1ccc(OC)cc1)c1ccccc1</smiles><smiles>[R]C(C)CC(=O)N1C(=O)OC(c2ccccc2)C(C)N1Cc1ccc(OC)cc1</smiles><smiles>COc1ccc(CN2C(C)C(c3ccccc3)OC(=O)N2C(=O)C(c2ccccc2)C(C)c2ccccc2)cc1</smiles>

In Figure 22 above, if the intermediate $\mathbf{7 8 c}$ was predominantly formed, the $R$-isomer (81a) would be the major isomer. On the other hand, if the intermediate $\mathbf{7 8 d}$ was predominantly formed, then the $S$-isomer (81b) would be expected to be the major isomer. However, there is a possibility of both intermediates competing with each other and forming in almost equal amounts. If this is the situation, then the observed low diastereoselectivity is unavoidable. 
More efforts towards increasing the diastereoselectivity of the conjugate addition: The $N_{4}$-paramethoxybenzyloxadiazinone from L-phenyl alaninol, synthesis and application

Following the attempts made to obtain high diastereoselectivities in the asymmetric conjugate additions from the Ephedra-based oxadiazinones, a new oxadiazinone, the $\mathrm{N}_{4}$-paramethoxybenzyloxadiazin-2-one (89) was also considered (Scheme 28). In this new system, Lphenylalaninol (85) was employed as the precursor for the oxadiazinone synthesis in place of the norephedrine (74). Based on the low diastereoselectivities obtained from the para-methoxybenzyl norephedrine-based oxadiazinone (73), a more sterically demanding group was envisioned as a good candidate to be considered as the stereochemical control element $\left(\mathrm{N}_{4}\right.$-substituent) (Figure 23). Unfortunately, the $(1 R, 2 S)$-norephedrine could not be used to accomplish this purpose.

Figure 23. Comparison between the norephedrine and the L-phenylalaninol based oxadiazinones.<smiles>CC(N)C(O)c1ccccc1</smiles>

(1R,2S)-norephedrine, 74<smiles>COc1ccc(CN2NC(=O)OC(c3ccccc3)C2C)cc1</smiles>

$(1 R, 2 S)$-norephedrine- $\mathrm{N}_{4}-\mathrm{PMB}$ oxadiazinone, 73 $\mathrm{PMB}=$-para-methoxybenzyl vs.<smiles>NC(CO)Cc1ccccc1</smiles>

L-phenyl alaninol, 85

vs<smiles>COc1ccc(CN2NC(=O)OCC2Cc2ccccc2)cc1</smiles>

L-phenyl alaninol- $\mathrm{N}_{4}$-PMB oxadiazinone, 89 
This is because of the scarcity and high cost associated with this compound. ${ }^{67}$ As a result, L-phenylalaninol (85), a compound derived from the natural $\alpha$-amino acid L-phenylalanine, was employed as an alternative precursor for the synthesis of the new oxadiazinones. Before proceeding to the isopropyl-substituted heterocycle, a derivative of the para-methoxybenzyl (PMB) substituted oxadiazinone (73), the L-phenylalaninol-based-N4-PMB oxadiazinone (89), was synthesized using the L-phenylalaninol starting material. The synthesis began with the reductive amination of the amino acid derivative L-phenylalaninol (85) with para-anisaldehyde in the presence of ethanol (100\%) (Scheme 28).

The reaction afforded the amino alcohol $\mathrm{N}_{4}$-para-methoxybenzyl L-phenyl alaninol (86) in a $78 \%$ yield. The $\mathrm{N}_{4}$-para-methoxybenzyl L-phenylalaninol product was then taken through $\mathrm{N}$-nitrosation reaction using sodium nitrite, an aqueous solution of $\mathrm{HCl}(3 \mathrm{M})$, and tetrahydrofuran which resulted in the target N-nitrosamine (89) in a 65\% yield. Without further purification, the $\mathrm{N}$-nitrosamine was subjected to $\mathrm{LiAlH}_{4}$ reduction in the presence of tetrahydrofuran to yield the target beta-hydroxy hydrazine (88) in a 31\% yield. The hydrazine product thus obtained was then dissolved in tetrahydrofuran and subjected to a cyclization reaction via the coupling agent carbonyl diimidazole (55). This reaction afforded the $\mathrm{N}_{4}$-paramethoxybenzyloxadiazin-2-one (89) in a 35\% yield after chromatography purification. 
Scheme 28. Synthesis of the L-phenylalanine based $\mathrm{N}_{4}$-para-methoxybenzyl-oxadiazin-2-one,

89.<smiles>N[C](CO)Cc1ccccc1</smiles>

85

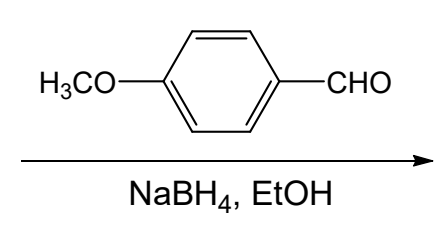

$78 \%$<smiles>COc1ccc(CNC(CO)C(F)(F)F)cc1</smiles>

86
$65 \%$

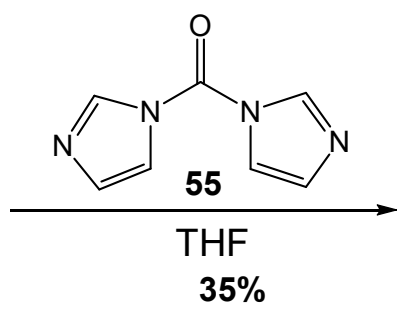

88<smiles>COc1ccc(CN2NC(=O)OC[C@H]2Cc2ccccc2)cc1</smiles>

89

Acylation and asymmetric conjugate addition with L-phenylalaninol-N $N_{4}$-para-methoxybenzyloxadiazinone

The L-phenylalaninol based $\mathrm{N}_{4}$-para-methoxybenzyloxadiazinone (89) thus obtained was subjected to an acylation reaction (Scheme 29) using trans-cinnamic acid (56) in the presence of 1-ethyl-3-(3-dimethylaminopropyl)carbodiimide (EDC) (57) coupling agent and 4dimethylaminopyridine (DMAP) catalyst (58). The L-phenylalaninol-N 4 -para-methoxybenzyl$\mathrm{N}_{3}$-cinnamoyl oxadiazinone (90) product obtained in this process was purified by column 
chromatography in a 65:35, hexane: ethyl acetate solvent system, which resulted in a $71 \%$ yield of the target product.

Scheme 29. Acylation of the L-phenylalanine based N4-para-methoxybenzyl-oxadiazinone, 89.<smiles>COc1ccc(CN2NC(=O)OCC2Cc2ccccc2)cc1</smiles>

89

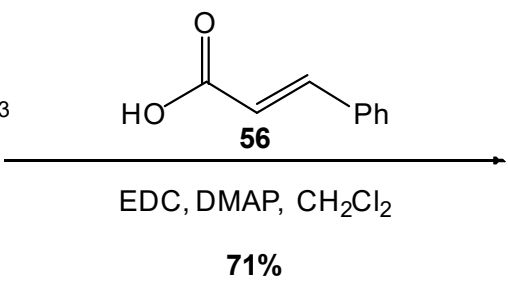

$71 \%$<smiles>COc1ccc(CN2C(C)COC(=O)N2C(=O)/C=C/c2ccccc2)cc1</smiles>

The pure $\mathrm{N}_{4}$-para-methoxybenzyl-N3-cinnamoyl oxadiazinone (90) obtained from the Steglich reaction above was analyzed by $500 \mathrm{MHz}{ }^{1} \mathrm{H}$ NMR and $125{ }^{13} \mathrm{C}$ NMR spectroscopy. The analysis of these spectra revealed that some of the signals were significantly broadened which suggested that this compound is conformationally flexible. Nonetheless, for the sake of experimentation, the acylated product was subjected to an asymmetric conjugate addition reaction (Scheme 30). 
Scheme 30: Asymmetric conjugation addition reaction with the $\mathrm{N}_{4}$-para-methoxybenzyl- $\mathrm{N}_{3}$ cinnamoyl oxadiazinone 91.
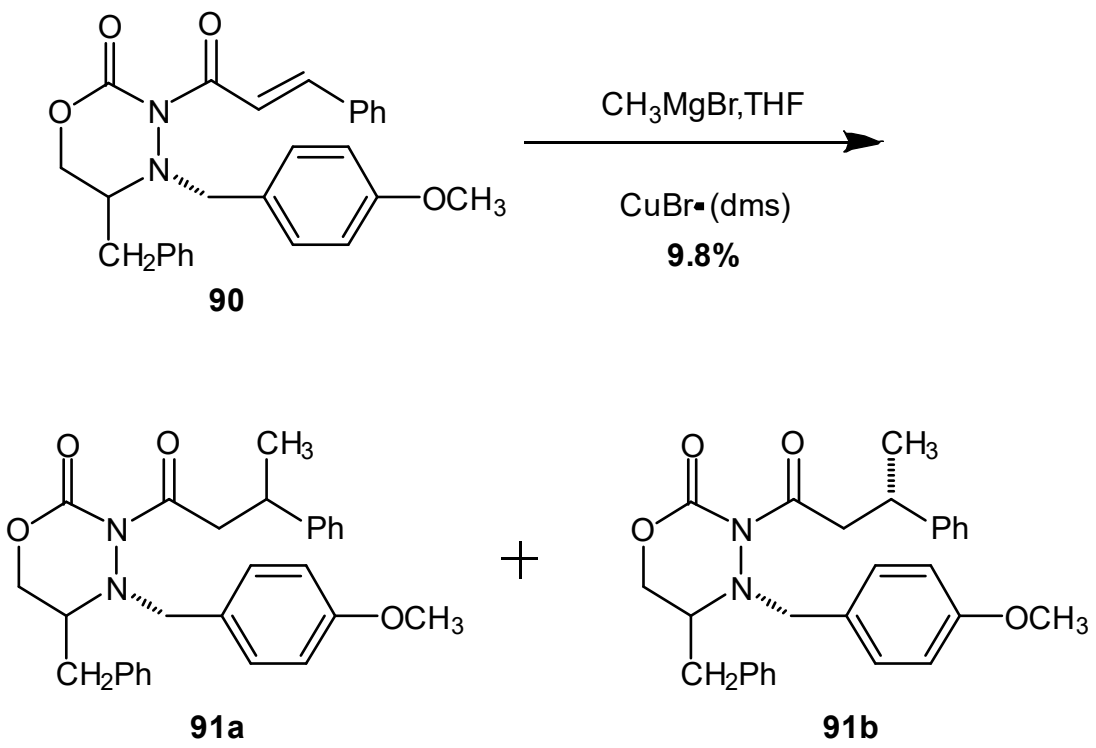

The conjugate addition reaction was carried out in the presence of methyl magnesium bromide, copper bromide (Normant reagent), tetrahydrofuran (THF) and dimethyl sulfide (DMS). The corresponding N3-(3-phenylbutanoyl)- N4-para-methoxybenzyl oxadiazinone target was obtained and purified by flash column chromatography, leading to the isolation of the target molecule as a mixture of diastereomers (91a and 91b) in an unoptimized yield of $9.8 \%$. From the analysis of the $500 \mathrm{MHz}{ }^{1} \mathrm{H}$ NMR spectrum of the conjugate addition product, significant line broadening was observed in multiple signals. This was indicative of conformational flexibility observed in the conjugate addition products. It was not possible to determine the reaction diastereoselectivity under these circumstances. This observation suggested that this system is not a good candidate for the asymmetry conjugate addition reaction. Hence, no further analysis was conducted on the reaction mixture. 
Initial attempts to increase the diastereoselectivity of the conjugate addition: The Lphenylalaninol-N4-isopropyl oxadiazinone synthesis and application

While the results from the asymmetric conjugate addition using the Ephedra-based oxadiazinones resulted in a diastereoselectivity of 5:1, there was still an interest in pursuing the development of an optimal chiral oxadiazinone template. It was proposed that the $\mathrm{N}_{4}-p$ methoxybenzyl group did not provide enough steric volume to influence the conjugate addition. Based on the limitation of the $\mathrm{N}_{4}-p$-methoxybenzyl system to generate the desired level of diastereoselection, a new oxadiazinone was envisioned wherein the $\mathrm{N}_{4}$-substituent would be more sterically demanding. To this end, a new oxadiazinone bearing an $\mathrm{N}_{4}$-isopropyl group was proposed in the place of the former $\mathrm{N}_{4}-p$-methoxybenzyl substituent (Figure 24).

Figure 24. Increasing the steric demand of the $\mathrm{N}_{4}$-substituent.

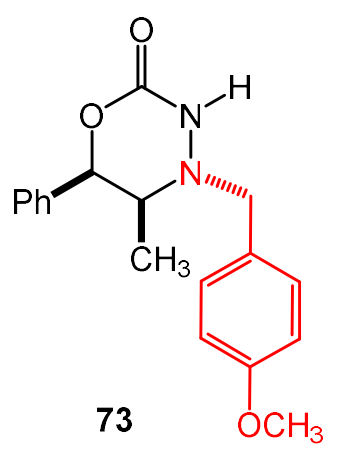

vs.<smiles>CC(C)[NH+]1NC(=O)OC(c2ccccc2)C1C</smiles>

92<smiles>CC(N)C(O)c1ccccc1</smiles>

(1R,2S)-norephedrine (74)

Sigma-Aldrich

Unfortunately, the proposed oxadiazinone (92) could not be prepared, as the chiral betaamino alcohol template, $(1 R, 2 S)$-norephedrine (74), was no longer commercially available from the only United States supplier, Sigma-Aldrich chemical (Merck KGaS) ${ }^{67}$, as noted earlier. To circumvent this problem, beta-amino alcohols sourced from commonly available alpha-amino 
acids were selected as the new chiral template (Figure 25). Thus, L-phenylalaninol (85) was employed in the newly proposed oxadiazinone (94). This new oxadiazinone would have the benefit of being sourced from an inexpensive, commonly available chiral starting material and offer a larger steric volume at the $\mathrm{N}_{4}$-position, and potentially lead to higher diastereoselection in the asymmetric conjugate addition process.

Figure 25. The design of a new L-phenylalaninol based $\mathrm{N}_{4}$-isopropyloxadiazinone.

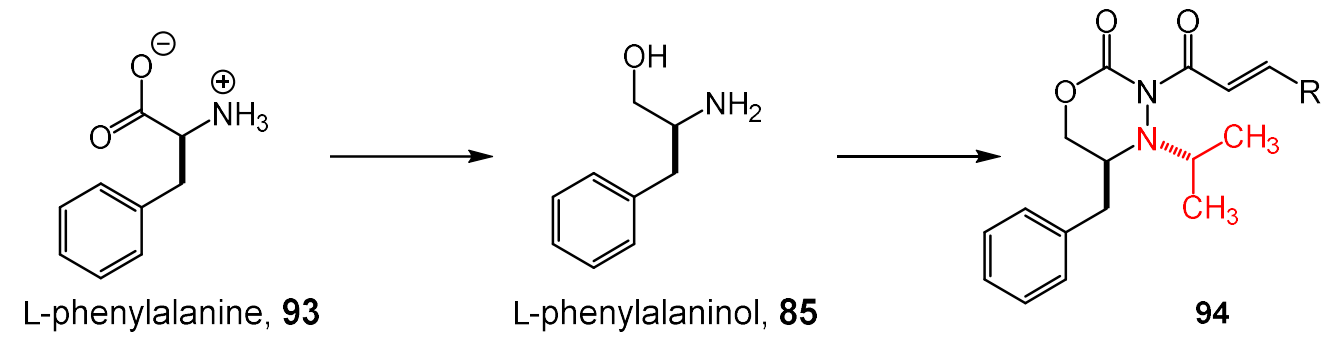

Synthesis of the L-phenyl alaninol based $N_{4}$-isopropyloxadiazinone

The synthesis of this oxadiazinone began with the reductive amination ${ }^{68,69}$ of commercially available L-phenylalaninol (85) with reagent grade acetone in the presence of acetic acid and sodium triacetoxyborohydride (Scheme 31). This process afforded the target $\mathrm{N}_{4}$ isopropyl-L-phenyl-alaninol (94c) in 44\% yield. The $\mathrm{N}_{4}$-isopropyl-L-phenylalaninol was then subjected to an N-nitrosation reaction in the presence of sodium nitrite, an aqueous solution of $\mathrm{HCl}(3 \mathrm{M})$, and tetrahydrofuran..$^{70,71}$ This reaction resulted in a near quantitative isolation of the N-nitrosamine product (94d) as a mixture of diastereomers with a percentage yield of 94\%. At this stage, the N-nitrosamine needed to be reduced to the hydrazine (94f). Our research group 
had used lithium aluminum hydride $\left(\mathrm{LiAlH}_{4}\right)^{72-74}$ to accomplish this task, but we wanted to pursue a reduction pathway that was more efficient and less dangerous. Thus, without further purification, the N-nitrosamine was reduced using the method of Kandasamy and coworkers, ${ }^{75}$ in which the N-nitrosamine was reacted with formamidine sulfinic acid (94e) in the presence of an aqueous solution of sodium hydroxide $(1 \mathrm{M})$ and methanol. This process yielded the desired hydrazine product (95) in 84\% yield.

Scheme 31. Synthesis of the L-phenylalaninol based $\mathrm{N}_{4}$-isopropyloxadiazinone.

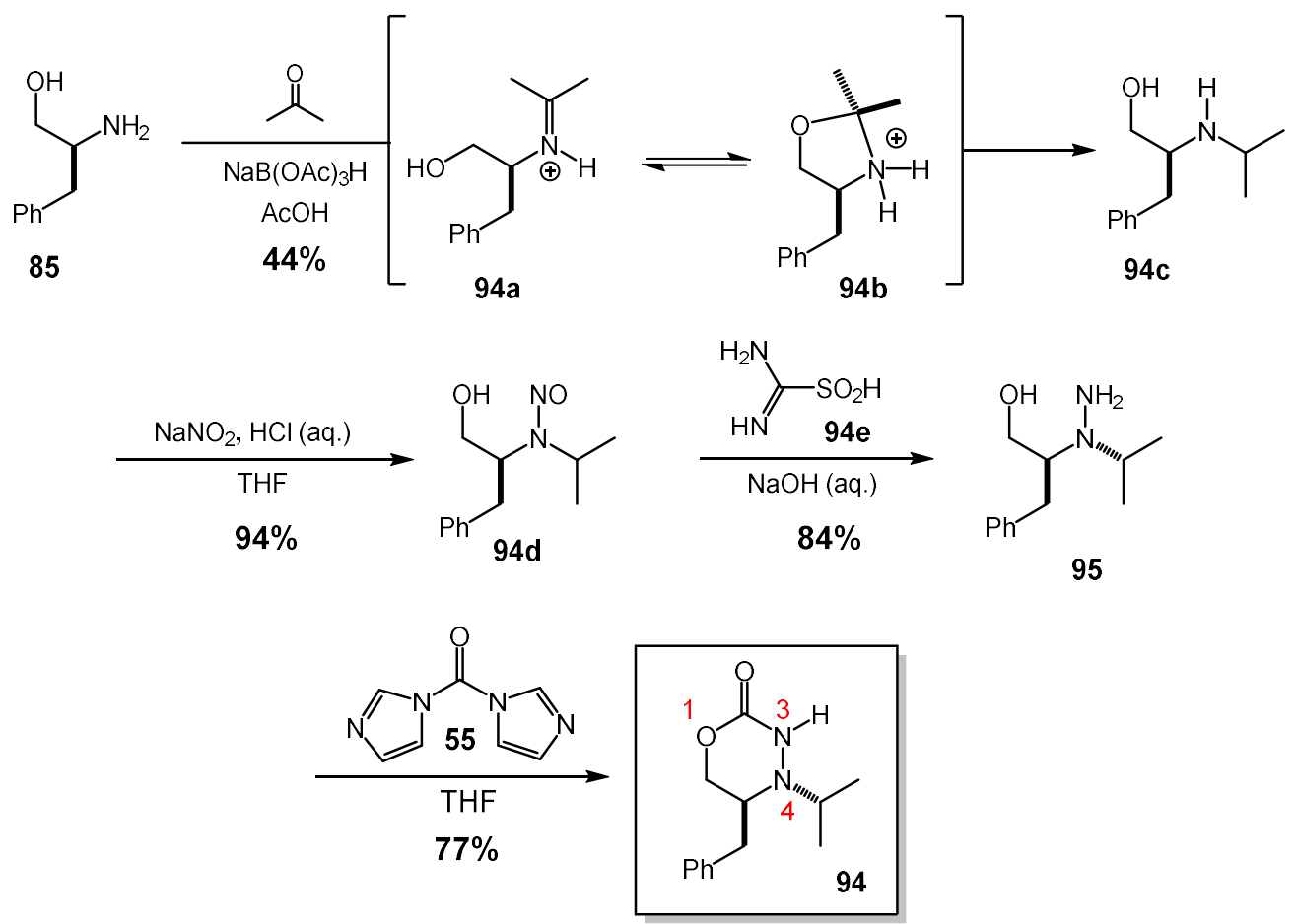

A potential reaction mechanism for this transformation is illustrated in Scheme 32. The overall reaction mechanism is divided into two stages. The first stage involves the decomposition of the formamidine sulfinic acid (94e) to give urea (95b) and ultimately, sulfoxylic acid (95e). In 
the second stage, the sulfoxylic acid reduces the nitrosamine by a process of nucleophilic addition and elimination of sulfur dioxide in two independent steps.

Scheme 32. Mechanism for the formamidine sulfinic acid reduction of N-nitrosamine $\mathbf{5 8 .}$
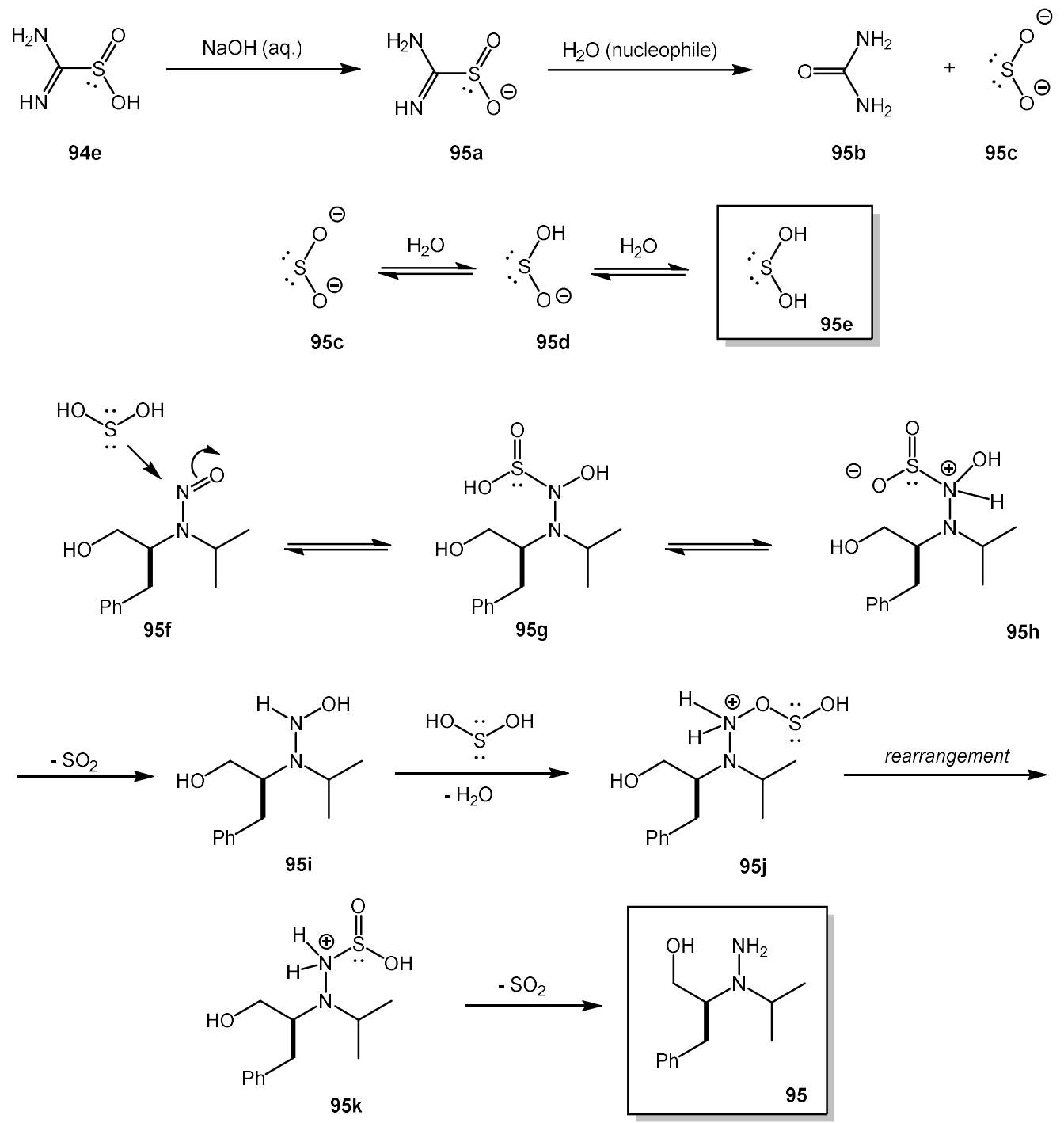

The hydrazine (95) thus obtained, without further purification, was then reacted with carbonyl diimidazole for 18 hours to induce cyclization as described in the method developed by Husson and coworkers ${ }^{53}$ to obtain the target $\mathrm{N}_{4}$-isopropyloxadiazinone (94). The crude product 
was then subjected to column chromatography purification in a 50:50 hexanes: ethyl acetate solvent system, resulting in an isolated chemical yield of $77 \%$.

Acylation and asymmetric conjugate addition with the $N_{4}$-isopropyloxadiazinone

The pure heterocycle (94) obtained from the cyclization reaction was taken through acylation reaction using the two pathways of trans-cinnamic acid and crotonyl chloride. The acylation reaction with trans-cinnamic acid was carried out in the presence of 1-ethyl-3-(3dimethylaminopropyl) carbodiimide (EDC) coupling agent, 4-dimethylaminopyridine (DMAP) catalyst and anhydrous dichloromethane (Scheme 33) to yield the cinnamoyl acylated oxadiazinone (96) in a 30\% yield after chromatography purification in a 75:25 hexanes: ethyl acetate solvent system. The $\mathrm{N}_{3}$-crotonyl variation was prepared by reacting the heterocycle (94) with trans-crotonyl chloride in the presence of sodium hydride and anhydrous dichloromethane (Scheme 34). The process yielded the acylated heterocycle (97) in an unoptimized yield of 18\% after chromatography purification (75:25 hexanes: ethyl acetate).

Scheme 33. Synthesis of $\mathrm{N}_{4}$-isopropyl-N 3 -cinnamoyloxadiaxinone.<smiles>CC(C)N1NC(=O)OCC1Cc1ccccc1</smiles>

94

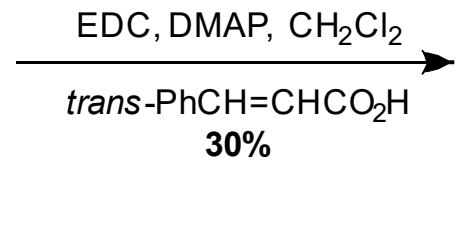

$\mathrm{Ph}$<smiles>CC(C)N1C(Cc2ccccc2)COC(=O)N1C(=O)/C=C/c1ccccc1</smiles> 
Scheme 34. Synthesis $\mathrm{N}_{4}$-isopropyl- $\mathrm{N}_{3}$-crotonyloxadiaxinone.

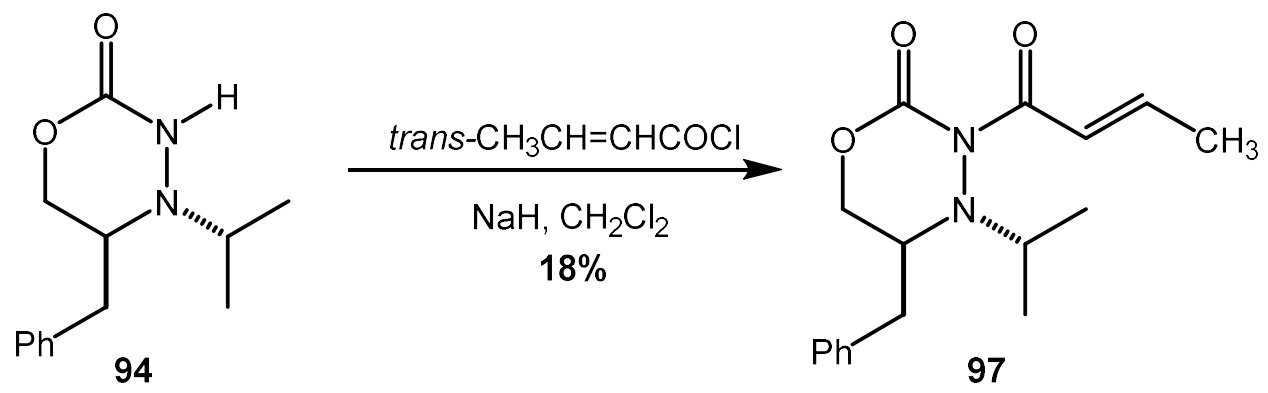

The $\mathrm{N}_{4}$-isopropyl-N3-cinnamoyloxadiaxinone (96) was further subjected to a conjugate addition reaction (Scheme 35) reaction using Normant reagent (methyl magnesium bromide and cupper (I) bromide dimethyl sulfite complex) in the presence of tetrahydrofuran. The target $\mathrm{N}_{3}$ (3-methylcinnamoyl)- $\mathrm{N}_{4}$-isopropyl oxadiazinone (98) was isolated as a mixture of diastereomers (98a \& 98b) in a 47\% yield after chromatography purification (85:15 hexanes: ethyl acetate).

Scheme 35. Synthesis of the $\mathrm{N}_{3}$-(3-methylcinnamoyl)- $\mathrm{N}_{4}$-isopropyl oxadiazinone (98)<smiles>CC(C)N1C(Cc2ccccc2)COC(=O)N1C(=O)/C=C/c1ccccc1</smiles>

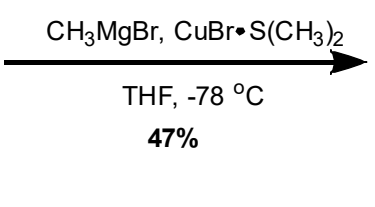<smiles>CC(CC(=O)N1C(=O)OCC(Cc2ccccc2)N1C(C)c1ccccc1)c1ccccc1</smiles><smiles>CC(C)N1C(Cc2ccccc2)COC(=O)N1C(=O)C[C@H](C)c1ccccc1</smiles>

Upon analysis of the crude prosuct with $500 \mathrm{MHz}{ }^{1} \mathrm{H}$ NMR, These products yielded an integration ratio of 1.5:1 in favor of the major diastereomer (Figure 26). 
Figure 26. $500 \mathrm{MHz}^{1} \mathrm{H}$ NMR spectrum of the $\mathrm{N}_{4}$-isopropyl- $\mathrm{N}_{3}-(3-$ methylcinnamoyl) oxadiazinone diastereomers $(\mathbf{9 8 a} \& \mathbf{9 8 b})$ conjugate addition product.

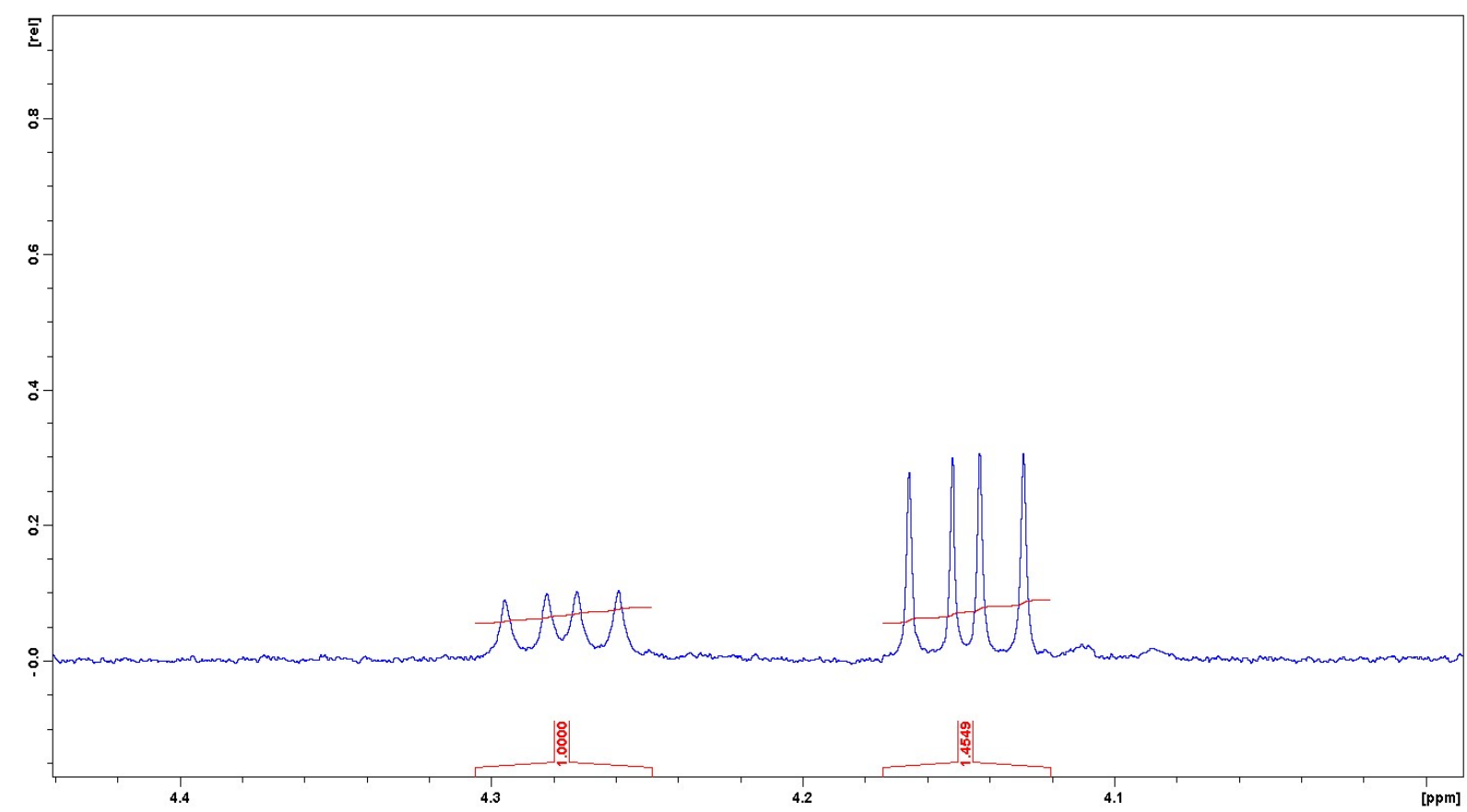

Following the same reaction procedure as the cinnamoyl derivative, the $\mathrm{N}_{3}$-crotonyl- $\mathrm{N}_{4}$ isopropyloxadiaxinone (97) was reacted with methyl magnesium bromide and cupper (I) bromide dimethyl sulfite complex in the presence of tetrahydrofuran (Scheme 36) to yield the target $\mathrm{N}_{3}$-(3-phenylbutanoyl)-N4-isopropyl oxadiazinone (99) as a mixture of diastereomers (99a \& 99b) in a 70\% yield after chromatography purification (85:15 hexanes: ethyl acetate). 
Scheme 36. Synthesis of the $\mathrm{N}_{3}$-(3-phenylbutanoyl)- $\mathrm{N}_{4}$-isopropyl oxadiazinone (75a \& 75b)

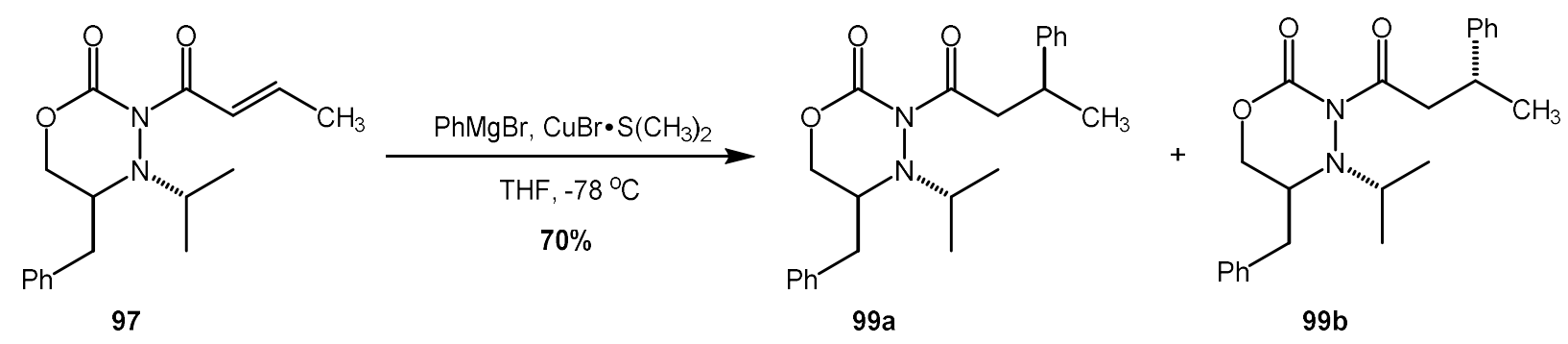

The crude conjugate addition product was analysized with $500 \mathrm{MHz}{ }^{1} \mathrm{H}$ NMR and a diastrereomeric ratio of 1.6:1 was observed in favor of the major isomer (Figure 27).

Figure 27. $500 \mathrm{MHz}{ }^{1} \mathrm{H}$ NMR spectrum of the $\mathrm{N}_{4}$-isopropyl- $\mathrm{N}_{3}$-(3-phenylbutanoyl) oxadiazinone (99a \& 99b) diastereomers.

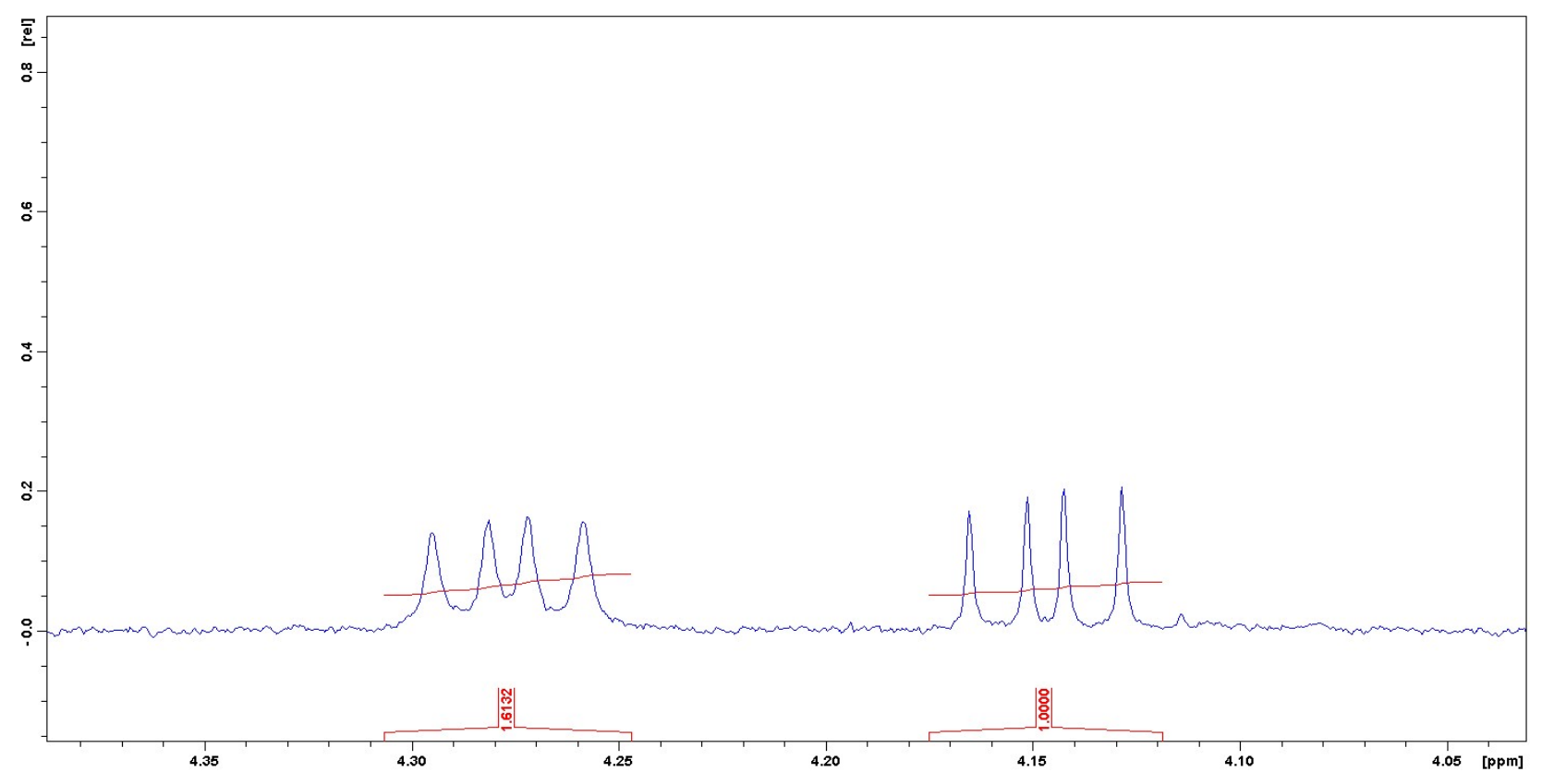


The low diastereoselectivity observed for the $\mathrm{N}_{4}$-isopropyl system was not what was expected. This set us thinking on what could be responsible for such outcome and it was again reasoned that this could be as a result of flexibilities around the $\mathrm{N}_{3}$-position of the acylated starting material (Figure 28) as seen in the case of the para-methoxybenzyl (PMB) systems.

Figure 28. Potential alteration of configuration in the conjugate addition starting material for the isopropyl system.<smiles>CC(C)N1C(Cc2ccccc2)COC(=O)N1C(=O)/C=C/c1ccccc1</smiles>

96

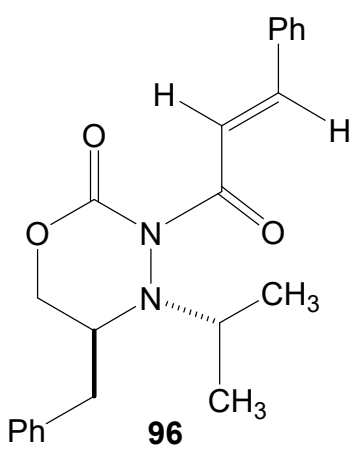

It was proposed that the steric volume of the isopropyl group caused the acyl side chain to adopt another orientation. At this point, the reaction condition for the asymmetric aldol addition reaction (the use of titamum reagent) ${ }^{76,77}$ was considered a possible solution to the flexibily problem. Hence, the isopropyl oxadiazinone was taken through some titanium chemistry, believing that complexing the material with metal compound such as titanium tetrachloride $\left(\mathrm{TiCl}_{4}\right)$ would hold the structure in place and give the reaction a better diastereoselectivities (Figure 29). 
Figure 29. Proposed solution to the configuration flexibility of the isopropyl system.

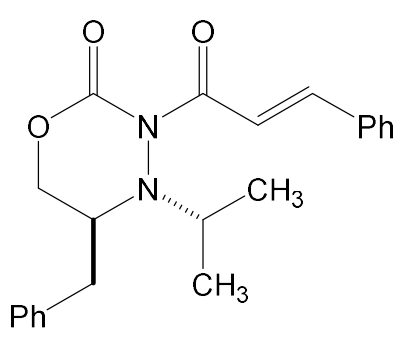

96

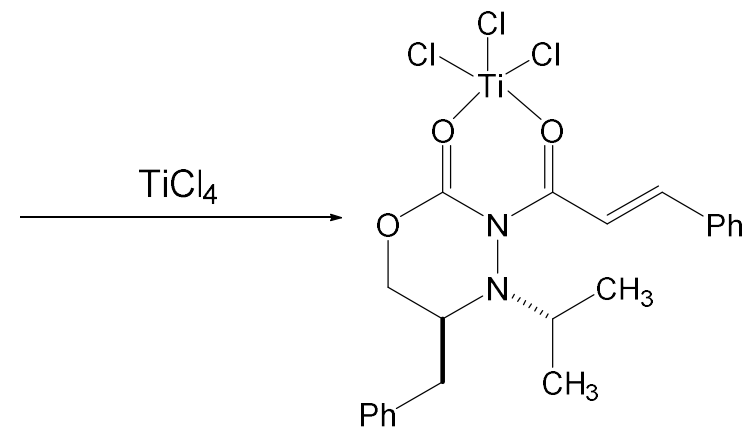

$96 a$

On this basis, the $\mathrm{N}_{3}$-cinnamoyl- $\mathrm{N}_{4}$-isopropyloxadiaxinone starting material (94) was taken through three separate conjugate addition reactions using titanium tetrachloride $\left(\mathrm{TiCl}_{4}\right)$, titanium (IV) isopropoxide ( $\left.\mathrm{Ti}(\mathrm{OiPr})_{4}\right)$ and methylmagnesium bromide. In the first reaction with $\mathrm{TiCl}_{4}$, the acylated heterocycle was reacted with methyl magnesium bromide and $\mathrm{TiCl}_{4}$ at $-78{ }^{\circ} \mathrm{C}$ in the presence of tetrahydrofuran (Scheme 36A). The second reaction followed the same protocol but in this case, the $\mathrm{TiCl}_{4}$ was replaced with $\left(\mathrm{Ti}(\mathrm{OiPr})_{4}\right)(\mathrm{Scheme} 36 \mathrm{~B})$. The third reaction was conducted at $-10{ }^{\circ} \mathrm{C}$ using only methyl magnesium bromide (Scheme $37 \mathrm{C}$ ). The proton NMR for the first and third reactions showed some evidence of endocyclic nucleophilic attack on the heterocycle rather than conjugate addition, resulting in ring opening and formation of hydrazines and carboxylic acids while the second reaction gave some addition products that could not be identified by proton NMR analysis. 
Scheme 37. Observation from the $500 \mathrm{MHz}{ }^{1} \mathrm{H}$ NMR spectra of the metal complexing reactions with the $\mathrm{N}_{4}$-isopropyl- $\mathrm{N}_{3}-(3$-phenylbutanoyl) oxadiazinone.

A.<smiles>CC(C)N1C(Cc2ccccc2)COC(=O)N1C(=O)/C=C/c1ccccc1</smiles>

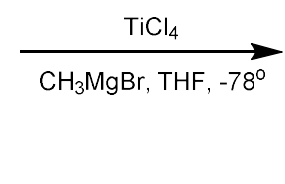<smiles>CC(=O)NN(C(C)C)C(CO)Cc1ccccc1</smiles>
100<smiles>O=C(O)/C=C/c1ccccc1</smiles>
26

B.<smiles>CC(C)N1C(=O)OCC(Cc2ccccc2)N1C(=O)/C=C/c1ccccc1</smiles>

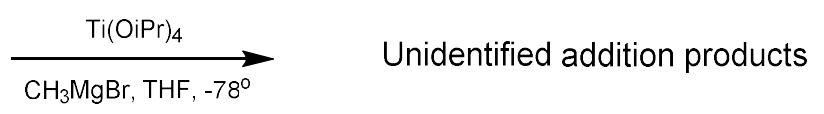

C.<smiles>CC(C)N1C(Cc2ccccc2)COC(=O)N1C(=O)/C=C/c1ccccc1</smiles>

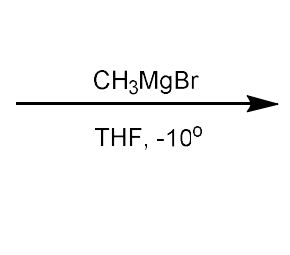<smiles>CC(C)N(N)C(CO)Cc1ccccc1</smiles>

95<smiles>O=C(O)/C=C/c1ccccc1</smiles>

26

Further attempts to increase the diastereoselectivity of the conjugate addition:

The L-phenylalaninol- $\mathrm{N}_{4}$-diphenylmethyloxadiazinone and the L-phenylalaninol-N4-(1,3-diphenyl-2 propyl) oxadiazinone

Having examined the Ephedra-based oxadiazinones, the $\mathrm{N}_{4}$-para-methoxybenzyl substituted oxadiazinones and the $\mathrm{N}_{4}$-isopropyl substituted oxadiazinone and the diastereoselectivities in all cases were lower than the desired diastereoselectivity (99:1 or 
greater), more oxadiazinone derivatives, the L-phenylalaninol- $\mathrm{N}_{4}$-(1,3-diphenyl-2 propyl)

oxadiazinone (101) and the L-phenylalaninol- $\mathrm{N}_{4}$-diphenylmethyl oxadiazinone (102) (Figure 30) will be synthesized and applied in the asymmetric conjugate addition reactions to determine if a better diastereoselectivity can be obtained through these new systems.

Figure 30. Proposed design improvement of the $\mathrm{N}_{4}$-substituted oxadiazinone.<smiles>CC(C)N1NC(=O)OCC1Cc1ccccc1</smiles>

Isopropyl, 94
VS<smiles>O=C1NN(C(Cc2ccccc2)Cc2ccccc2)C(Cc2ccccc2)CO1</smiles>

1,3-diphenyl-2-propyl, 101<smiles>O=C1NC(Cc2ccccc2)N(C(c2ccccc2)c2ccccc2)C(Cc2ccccc2)CO1</smiles>

Diphenylmethyl, 102

A proposed reaction pathway to the synthesis of these new oxadiazinones are described below.

Proposed attempt to increase the diastereoselectivity of the conjugate addition: the $N_{4}$-1,3-diphenyl-2-propyloxadiazinone

In a bid to improve the diastereoselectivity over the $\mathrm{N}_{4}$-position of the oxadiazinone, a new ring system will be pursued. This new system involves the replacement of the isopropyl group at the $\mathrm{N}_{4}$-position with the much larger 1,3-diphenyl-2-propyl group (Figure 31). 
Figure 31. Structural comparison between the $\mathrm{N}_{4}$-isopropyl and the $\mathrm{N}_{4}$-1,3-diphenyl-2-propyl oxadiazinones.

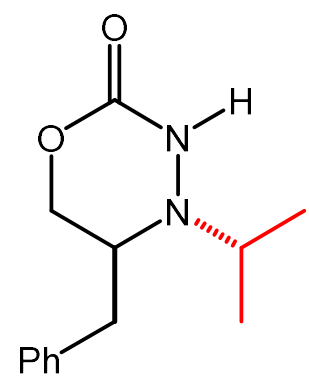

Isopropyl, 94

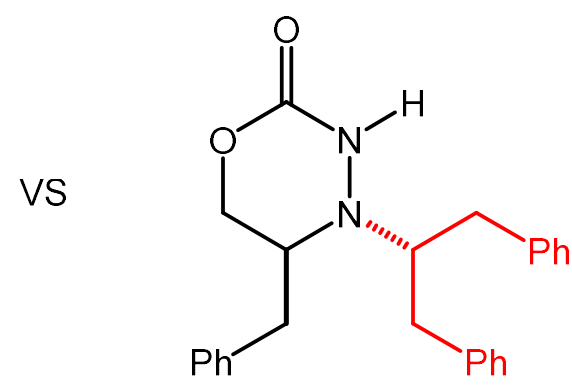

1,3-diphenyl-2-propyl, 101

The synthesis of this system will be accomplished by reacting the L-phenylalaninol (85) starting material with 1,3-diphenylpropan-2-one (103) in the presence of sodium triacetoxyborohydride and acetic acid (Scheme 38 ) to obtain the amino alcohol $\mathrm{N}_{4}$-(1,3-diphenyl2-propyl)-L-phenyl-alaninol (104) which will then be subjected to N-nitrosation reaction using sodium nitrite and an aqueous solution of $\mathrm{HCl}(3 \mathrm{M})$ using THF solvent to obtain $\mathrm{N}$-nitrosamine (105).The N-nitrosamine can then be subjected to reduction reaction in the presence of formamidinesulfinic acid (94a), an aqueous solution of sodium hydroxide (1M), and methanol. This will be immediately followed with the cyclization of the hydrazine in the presence of carbonyl diimidazole (55) and tetrahydrofuran to obtain the $\mathrm{N}_{4}$-1,3-diphenyl-2propyloxadiazinone. 
Scheme 38. Proposed synthesis of the L-phenyl alaninol based N4-1,3-diphenyl-2propyloxadiazinone.
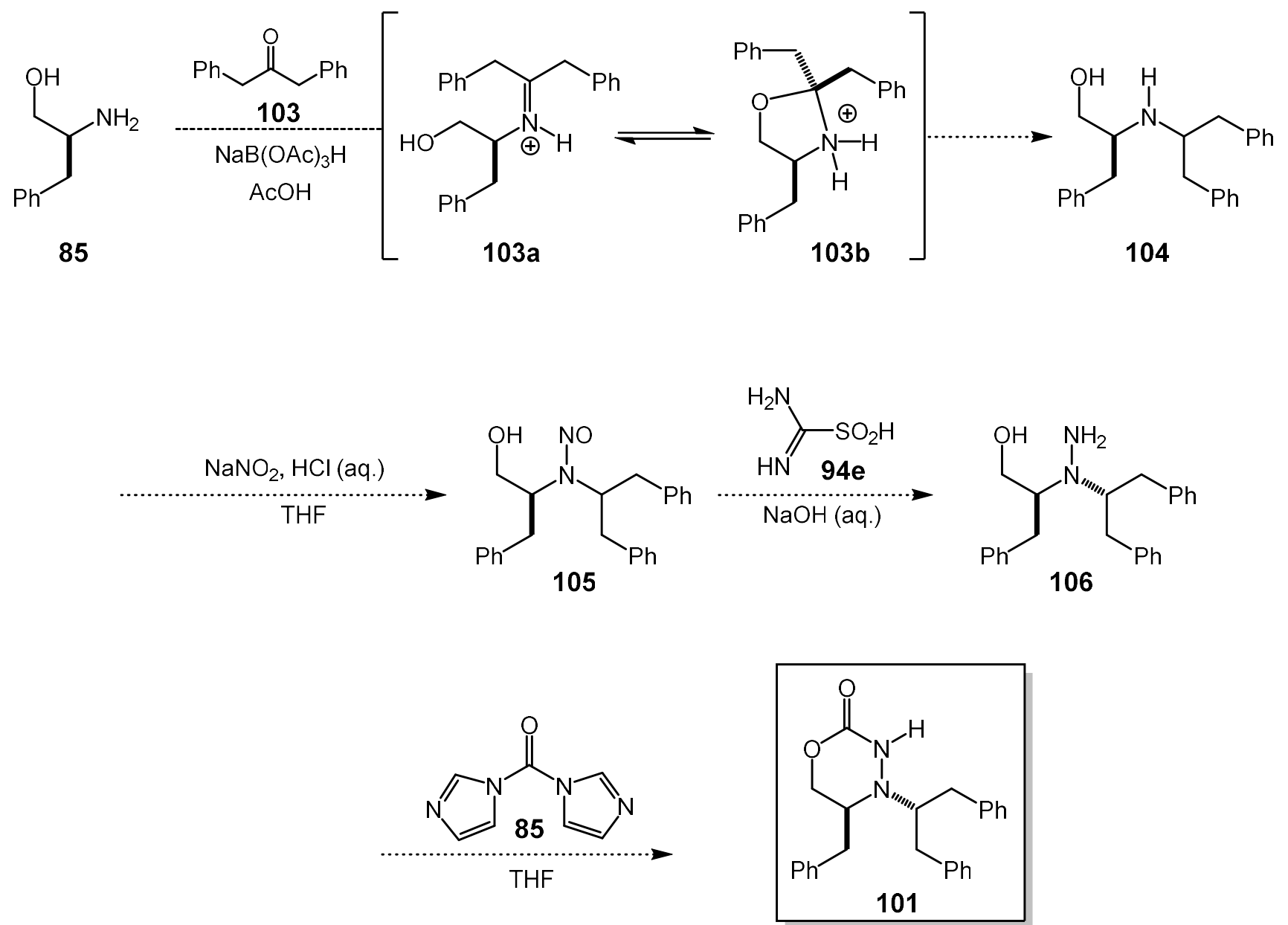
Proposed acylation and asymmetric conjugate addition with the $N_{4}-1,3-d i p h e n y l-2-$

propyloxadiazinone

The N4-1,3-diphenyl-2-propyl heterocycle obtained from the above process will be taken through the Steglich and crotonyl acylation reactions (Scheme 39). The acylated product will in turn be subjected to the conjugate addition reactions (Scheme 40). The conjugate addition products that will be obtained will then be analyzed by proton NMR to determine the stereoselectivities of the new cyclic system.

Scheme 39. Proposed Steglich reaction (top) and crotonyl acylation of the $\mathrm{N}_{4}$-1,3-diphenyl-2propyloxadiazinone.<smiles>O=C1NN(C(Cc2ccccc2)Cc2ccccc2)C(Cc2ccccc2)CO1</smiles>

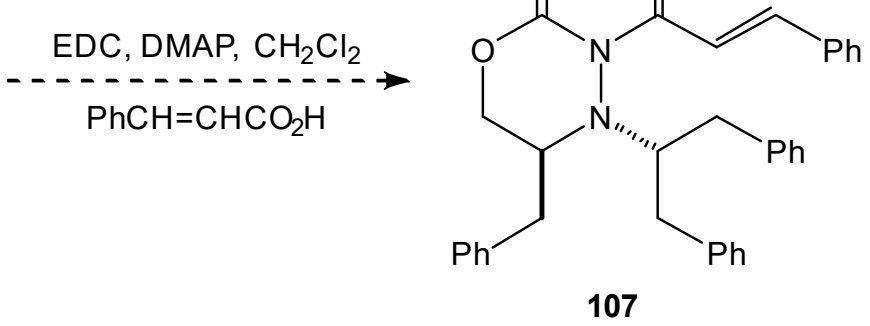<smiles>O=C1NN(C(Cc2ccccc2)Cc2ccccc2)C(Cc2ccccc2)CO1</smiles>

101

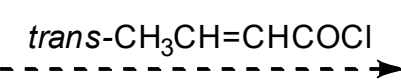

$\mathrm{LiH}, \mathrm{CH}_{2} \mathrm{Cl}_{2}$<smiles>C/C=C/C(=O)N1C(=O)OCC(Cc2ccccc2)N1C(Cc1ccccc1)Cc1ccccc1</smiles>

108 
Scheme 40. Proposed asymmetric conjugation addition with the $\mathrm{N}_{4}-1,3$-diphenyl-2-

propyloxadiazinone.

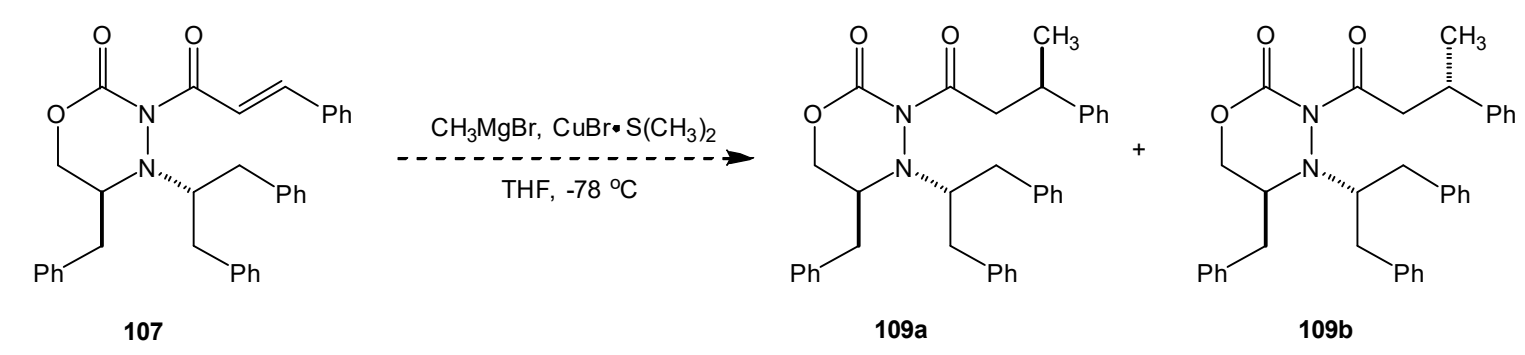<smiles>C/C=C/C(=O)N1C(=O)OCC(Cc2ccccc2)N1[C@H](Cc1ccccc1)c1ccccc1</smiles><smiles>CC(CC(=O)N1C(=O)OCC(Cc2ccccc2)N1C(Cc1ccccc1)c1ccccc1)c1ccccc1</smiles><smiles>C[C@@H](CC(=O)N1C(=O)OCC(Cc2ccccc2)N1C(Cc1ccccc1)c1ccccc1)c1ccccc1</smiles>

A few reactions have been conducted with the L-phenylalaninol- $\mathrm{N}_{4}-(1,3-$ diphenyl-2propyl) oxadiazinone (101) which were not very successful. The system is still under study to determine the best reaction conditions for the oxadiazinone synthesis.

Proposed attempt to increase the diastereoselectivity of the conjugate addition:

\section{$N_{4}$-diphenylmethyloxadiazinone}

The next oxadiazinone that will be examined is the L-phenylalaninol- $\mathrm{N}_{4}$-diphenylmethyl oxadiazinone (102). In this system, the $\mathrm{N}_{4}$-substituent will be the much larger diphenylmethyl group (Figure 32). As a matter of fact, work has already begun on the synthesis of this oxadiazinone. The first three reactions (reductive amination, reduction and nitrosation) have been successfully conducted (Scheme 41). 
Figure 32. Structural comparison between the $\mathrm{N}_{4}$-1,3-diphenyl-2-propyl oxadiazinones (101) and the $\mathrm{N}_{4}$-diphenylmethyl oxadiazinones (102).<smiles>O=C1NN(C(Cc2ccccc2)Cc2ccccc2)C(Cc2ccccc2)COC1=O</smiles>

1,3-diphenyl-2-propyl, 101<smiles>O=C1NN(C(c2ccccc2)c2ccccc2)C(Cc2ccccc2)CO1</smiles>

Diphenylmethyl, 102

Scheme 41. Synthesis of the $\mathrm{N}_{4}$-diphenylmethyl oxadiazinones (102).<smiles>NC(Br)CO</smiles>

85

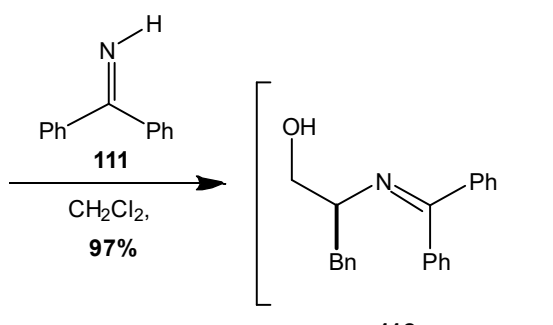

112<smiles>OCC(Cc1ccccc1)N(Cc1ccccc1)Cc1ccccc1</smiles>

$112 \mathrm{a}$

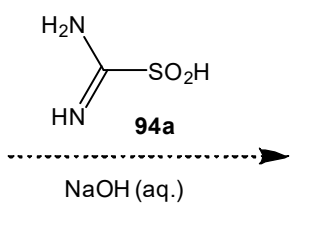<smiles>NN(C(CO)Cc1ccccc1)C(c1ccccc1)c1ccccc1</smiles>

115

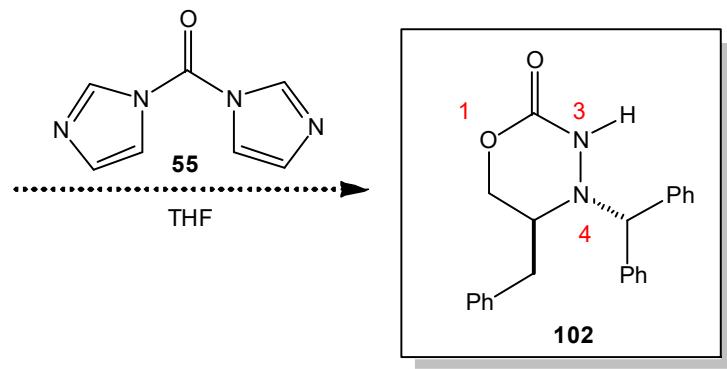


The synthesis began with the reaction of the L-phenylalaninol (85) starting material with benzophenone imine (111) in the presence of anhydrous dichloromethane. The target benzophenone imine of phenylalaninol (112) was obtained as a yellow solid in a 97\% yield after recrystallization. This was followed by reduction of the benzophenone imine of phenylalaninol using sodium borohydride in the presence of methanol and tetrahydrofuran which yielded the reduced amino alcohol (113) in a near quantitative yield of $97 \%$. The next step was the Nnitrosation of the benzophenone imine of phenylalaninol; however, there was a concern that the substrate would undergo acid catalyzed deprotection of the diphenyl methyl group under the standard conditions of N-nitrosation (sodium nitrite/hydrochloric acid). To this end, the substrate was reacted with tert-butyl nitrite (116) ${ }^{78}$ (Scheme 42) to circumvent the direct use of an acidic solution.

Scheme 42. Attempted N-nitrosation of $N$-diphenylmethyl-L-phenylalaninol.

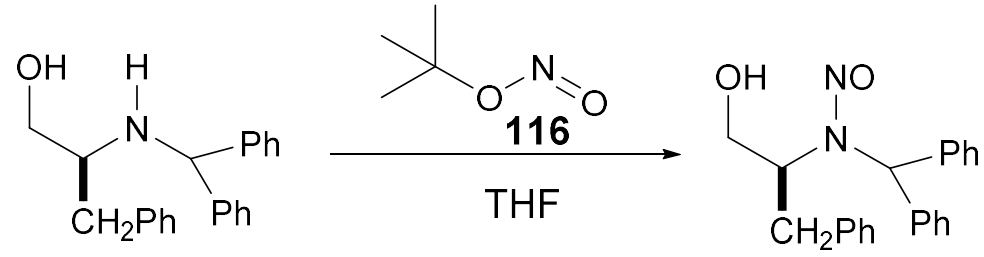

\section{3}

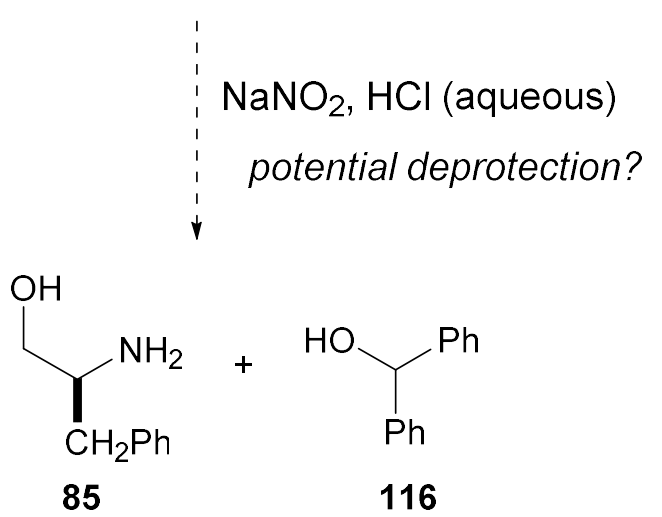


Unfortunately, the use of tert-butyl nitrite failed to successfully cause the N-nitrosation of the $N$-diphenylmethyl-L-phenylalaninol substrate. This was evident from the complexity of the $500 \mathrm{MHz}{ }^{1} \mathrm{H}$ NMR spectrum of the crude reaction mixture and from the analysis of the thin layer chromatography plate that suggested the presence of starting material, the N-nitrosation products, and other unidentified byproducts. To resolve this problem, sodium nitrite $\left(\mathrm{NaNO}_{2}\right)$ and aqueous hydrochloric acid $(\mathrm{HCl})$ (the original reaction conditions) were reconsidered. Thus, the starting material was dissolved in THF and hydrochloric acid and reacted with sodium nitrite (Scheme 43). We were gratified to learn that the $\mathrm{N}$-nitrosation reaction was more successful under these new conditions. This process resulted in the formation of the target product (114) in conjunction with benzophenone through some deprotection/oxidation pathway. The product was isolated as a mixture of diastereomers (114a \& 114b) in a 94\% yield.

Scheme 43. N-nitrosation of $N$-diphenylmethyl-L-phenylalaninol with sodium nitrite and hydrochloric acid.<smiles>CC(CO)NC(c1ccccc1)c1ccccc1</smiles>

113

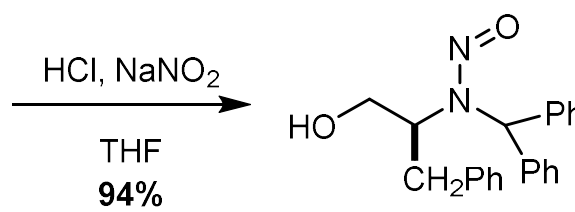

(E)-diasteromer, 114a<smiles>CC(CO)N(N=O)C(c1ccccc1)c1ccccc1</smiles>

(Z)-diasteromer, 114b

The N-nitrosamine (114) obtained in this process will be subjected to reduction reaction using the formamidine sulfinic acid (94a) reaction conditions to obtain the $\mathrm{N}_{4}$-diphenylmethyl substituted hydrazine (115) which will be immediately followed with cyclization in the presence of carbonyl diimidazole (55) and tetrahydrofuran to obtain the $\mathrm{N}_{4}$-1,3-diphenylmethyl oxadiazinone (102). 


\section{CHAPTER III: CONCLUSION AND FUTURE DIRECTIONS}

In search of a suitable chiral template for the synthesis of the medicinal agent tolterodine via asymmetric conjugate addition, a series of heterocycles known as oxadiazinones were synthesized. These compounds were then applied in asymmetric conjugate addition reactions and analyzed.

First, three members of the Ephedra alkaloids, namely $(1 R, 2 S)$-ephedrine; $(1 S, 2 S)$ pseudoephedrine and $(1 R, 2 S)$-norephedrine were employed in the synthesis of the corresponding oxadiazinones. This was followed by the use of $\alpha$-amino acid, L-phenyl alaninol, as a precursor for the synthesis of the oxadiazinones.

Of the three members of the Ephedra alkaloid family, the ephedrine-based oxadiazinone yielded the highest diastereoselectivity when subjected to asymmetric conjugate addition reaction conditions. In contrast, the pseudoephedrine based oxadiazinone displayed a significant line broadening of diagnostic peaks in both ${ }^{1} \mathrm{H}$ NMR and ${ }^{13} \mathrm{C}$ NMR spectra of the acylated product, an indication that the molecule is conformationally flexible. This kind of line broadening was also observed in one of the L-phenylalaninol based systems.

It was projected that having a more sterically demanding substituent at the $\mathrm{N}_{4}$-position (the stereochemical controlling element) of the oxadiazinones would help in improving the diastereoselectivity. However, the observed result was that the diastereoselectivity of the asymmetric conjugation decreased. Upon replacing the methyl group at the $\mathrm{N}_{4}$-positions of the ephedrine and pseudoephedrine oxadiazinones with para-methoxy benzyl (PMB) and isopropyl groups in L-phenyl alaninol based oxadiazinones, a subsequent decrease in diastereoselectivity was observed. This implies that, as the steric bulk increases, diastereoselectivity decreases. This 
was reasoned to be due to structural flexibility due to the steric hinderance constituted by the bulkiness of the $\mathrm{N}_{4}$-substrituent.

Complexing the acylated heterocycles with a transition metal in order to improve the compounds' conformational rigidity was considered a possible remedy. Titanium tetrachloride and titanium isopropoxide were used as the complexing agents. However, the results observed showed no indication of asymmetric conjugate addition. Metals other than titanium may ultimately give a different result.

In terms of future works, other metals will be considered in achieving conformational rigidity of the acylated substrates. Also, the conjugate addition products will be taken through hydrolysis in order to recover the chiral carboxylic acid side chains which will thereafter be employed in the synthesis of the medicinal agent tolterodine.

Overall, the oxadiazinones have proven to be a viable chiral template in aldol addition reaction and has shown potentials in conjugate addition. These compounds will be further developed to obtain an improved diastereoselectivity of the system. 


\section{REFERENCES}

1. https://www.azolifesciences.com/article/Chirality-in-Biochemistry.aspx

2. Barta, N. S.; Stille, J. R.; J. Chem. Edu. 1994, 71, $20-23$.

3. Zhao, Y.; Askarpour, A. N.; Sun, L.; Shi, J.; Li, X.; Alu, A. Nat. Commun. 2017, 8, 1-8.

4. McConathy, J.; Owens, M. J. J. Clin. Psychiatry 2003, 5, 70-73.

5. https://www.bioexplorer.net/building-blocks-of-lipids.html/

6. https://sites.google.com/site/optionbibchematisoi/b-10-stereochemistry-in-biomolecules

7. Ameredes, B. T.; Calhoun, W. J. Frontiers in Bioscience - Elite 2010, 2E, 1081-1092.

8. Welch, W. M.; Kraska, A. R. Sarges, R.; Koe, B. K. J. Med. Chem. 1984 27, 1508-1515.

9. Bull, S. D.; Davies, S. G.; Epstein, S. W.; Ouzman, J. V. A. Tetrahedron:

Asymmetry 1998, 9, 2795-2798.

10. Zhang, S.; Zheng, Y.; An, H.; Aguila, B.; Yang, C-X.; Dong, Y.; Xie, W.; Cheng, P.; Zhang Z.; Chen, Y.; Ma, S. Angew. Chem. Int. Ed. 2018, 57, 16754-16759.

11. Burley, D. M.; Lenz, W. Lancet 1962, 279, 271-272.

12. Lenz, W. A. Teratology 1988, 38, 203-215.

13. Tokunaga, E.; Yamamoto, T.; Shibata, N. Nature 2018, 8, 17131-17137.

14. (a) Blaschke, G.; Kraft, H. P.; Fickentscher, K.; Kohler, F.; Arzneim.-Forsch 1979, 29 , 1640-1642. (b) Tian, C.; Xiu, P.; Meng, Y.; Zhao, W.; Wang, Z.; Zhou, R. Chem. Eur. J. 2012, 18, 14305-14313. (c) Vianna, F. S. L.; Kowalski, T. W.; Fraga, L. R.; Sanseverino, M. T. V.; Schuler-Faccini, L. Eur. J. Med. Genet. 2017, 60, 12-15.

15. Smitrovich, J. H.; Boice, G. N.; Qu, C.; DiMichele, L.; Nelson, T. D.; Huffman, M. A.; Murry, J.; McNamara, J.; Reider, P. J Org. Lett. 2002, 4, 1963-1966. 
16. Zadsirjan, V.; Heravi, M. M. Curr. Org. Synth. 2018, 15, 3-20.

17. Byrd, K. M. Beilstein J. Org. Chem. 2015, 11, 530-562.

18. Leonard, J.; Díez-Barra, E.; Merino, S. Eur. J. Org. Chem. 1998, 2051-2061.

19. Tomioka, K.; Suenaga, T.; Koga, K. Tetrahedron Lett. 1986, 27, 369-372.

20. Cao, X.; Liu, F.; Lu, W.; Chen, G.; Yu, G.-A.; Liu, S. H. Tetrahedron Lett. 2008, 64, 5629-5636.

21. Reid, G. P.; Brear, K. W.; Robins, D. J. Tetrahedron: Asymmetry 2004, 15, 793-801.

22. Bergdahl, M.; Iliefski, T.; Nilsson, M.; Olsson, T. Tetrahedron Lett. 1995, 36 ,32273230.

23. Seki, C.; Hirama, M.; Sato, T.; Takeda, Saya; K., Y.; Ishigaki, K.; Ohuchi, M.; Yokoi, K.; Nakano, H.; Uwai, K.; Takano, N.; Umemura, K.; Matsuyam, H. Heterocycles 2012, $85,1045-1052$.

24. Murthy, K. S. K.; Rey, A. W.; Tjepkema, M. Tetrahedron Lett. 2003, 44, 5355-5358.

25. Chiacchio, U.; Corsaro, A.; Gambera, G.; Rescifina, A.; Piperno, A.; Romeo, R.; Romeo, G. Tetrahedron: Asymmetry 2002, 13, 1915-1921.

26. Alonso, B.; Ocejo, M.; Carrillo, L.; Vicario, J. L.; Reyes, E.; Uria, U. J. Org. Chem. 2013, $78,614-627$.

27. Ocejo, M.; Carrillo, L.; Badía, D.; Vicario, J. L.; Fernandez, N.; Reyes, E. J. Org. Chem. 2009, 74, 4404-4407.

28. (a) Reyes, E.; Vicario, J. L.; Carrillo, L.; Badía, D.; Iza, A.; Uria, U. Org. Lett. 2006, 8, 2535-2538. (b) Reyes, E.; Vicario, J. L.; Carrillo, L.; Badía, D.; Uria, U.; Iza, A. J. Org. Chem. 2006, 71, 7763-7772.

29. Etxebarria, J.; Vicario, J. L.; Badía, D.; Carrillo, L. J. Org. Chem. 2004, 69, 2588-2590. 
30. (a) Zhou, Y.; Jermaks, J.; Keresztes, I.; MacMillan, S. N.; Collum, D. B. J. Am. Chem. Soc. 2019, 141, 5444-5460. (b) Yang, B. H.; Chen, H.; Gleason, J. L.; Myers, A. G. J. Am. Chem. Soc. 1994, 116, 9361.

31. Zhi, W.; Li, J.; Zou, D. Wu, Y.; Wu, Y. J. Org. Chem. 2017, 82, 12286-12293.

32. Leitis, Z.; Lūsis, V. Tetrahedron: Asymmetry 2016, 27, 843-851.

33. Yodwaree, S.; Soorukram, D.; Kuharkarn, C.; Tuchinda, P.; Reutrakul, V.; Pohmakotr, M. Org. Biomol. Chem. 2014, 12, 6885-6894.

34. Sabala, R.; Hernández-Garcia, L.; Ortiz, A.; Romero, M.; Olivo, H. F. Org. Lett. 2010, 12, 4268-4270.

35. Hein, J. E.; Zimmerman, J.; Sibi, M. P.; Hultin, P. G. Org. Lett. 2005, 7, 2755-2758.

36. Dambacher, J.; Bergdahl, M. J. Org. Chem. 2005, 70, 580-589.

37. Sibi, M. P.; Ji, J.; Sausker, J. B.; Jaspere, C. P. J. Am. Chem. Soc. 1999, 121, 7517-7526.

38. Andersson, P. G. Schink, H. E.; Osterlund, K. J. Org. Chem. 1998, 63, 8067-8070.

39. Sabala, R.; Assad, S.; Mendoza, A.; Jiménez, J.; Sansinenea, E.; Ortiz, A. Tetrahedron Lett. 2019, 60, 1741-1744.

40. Assad, S.; Sabala, R.; Jiménez, J.; Sansinenea, E.; Ortiz, A. Tetrahedron Lett. 2019, 60, 1646-1648.

41. Kaneko, H.; Takahashi, S.; Kogure, N.; Kitajima, M.; Takayama, H. J. Org. Chem. 2019, $84,5645-5654$.

42. Evans, D. A.; Ennis, M.D.; Mathre, D.J. J. Am. Chem. Soc. 1982, 104, 1737-1739.

43. Yan, T. H.; Tan, C. W.; Lee, H. C.; Lo, H. C.; Huang, T. Y. J. Am. Chem. Soc. 1993, 115, 2613-2621.

44. Sibi, M. P.; Deshpande, P. K.; Ji, J. Tetrahedron Lett. 1995, 36, 8965-8968. 
45. Davies, S. G.; Sanganee, H. J. Tetrahedron: Asymmetry 1995, 6, 671-674.

46. Phoon, C. W.; Abell, C. Tetrahedron Lett. 1998, 39, 2655-2658.

47. Crimmins, M. T.; Chaudhary, K. Org. Lett. 2000, 2, 775-777.

48. de Parrodi, C. A.; Clara-Sosa, A.; Perez, L.; Quintero, L.; Maranon, V.; Toscano, R.A.; Avina, J. A.; Roja-Lina, S.; Juaristi, E. Tetrahedron: Asymmetry 2001, 12, 69-79.

49. Thielman, J. R.; Sherman, D. H.; Williams, R. M. J. Org. Chem. 2020, 85, 3812-3823.

50. Trepanier, D. L.; Elbe, J. N.; Harris, G. H. J. Med. Chem. 1968, 11, 357-360.

51. Trepanier, D. L. Harris, J. N. US patent 3,377,345 (1968). Chem. Abstracts 1969, 70, $78026 \mathrm{c}$

52. Roussi, F.; Bonin, M.; Chiaroni, A.; Micouin, L.; Riche, C.; Husson, H. Tetrahedron Lett. 1998, 39, 8081-8084.

53. Roussi, F.; Chauveau, A.; Bonin, M.; Micouin, L.; Husson, H. Synthesis 2000, 1170-1179.

54. Roussi, F.; Bonin, M.; Chiaroni, A.; Micouin, L.; Riche, C.; Husson, H. Tetrahedron Lett. 1999, 40, 3727-3730.

55. Casper, D. M.; Hitchcock, S. R. Tetrahedron: Asymmetry 2003, 14, 517-521.

56. Casper, D. M.; Burgeson, J. R.; Esken, J. M.; Ferrence, G. M; Hitchcock, S. R. Org. Lett. 2002, 4, 3739-3742.

57. Vianna, F. S. L.; Kowalski, T. W.; Fraga, L. R.; Sanseverino, M. T. V.; Schuler-Faccini, L. Eur. J. Med. Genet. 2017, 60, 12-15.

58. Yoo, K.; Kim, H.; Yun, J. J. Org. Chem. 2009, 74, 4232-4235.

59. Roussi, F.; Chauveau, A.; Bonin, M.; Micouin, L.; Husson, H.-P. Synthesis 2000, 8, 1170-1179.

60. Neises, B.; Steglich, W. Angew. Chem. Int. Ed. 1978, 17, 522-524. 
61. Ashby, E. C.; Goel, A. B. J. Org. Chem. 1983, 48, 2125-2130.

62. Mechelke, M. F.; Wiemer, D. F. J. Org. Chem. 1999, 64, 4821-4829.

63. Ashby, E. C.; Goel, A. B. J. Org. Chem. 1983, 48, 2125-2130.

64. Mechelke, M. F.; Wiemer, D. F. J. Org. Chem. 1999, 64, 4821-4829.

65. Weidler, A-M.; Bergson, G. Acta Chem. Scand. 1964, 18, 1484-1486.

66. Pikul, S.; Corey, E. Org. Synth. 1993, 71, 22-26.

67. As of December 2019, Sigma-Aldrich has only four 1-gram bottles remaining at a cost of $\$ 62.20$ each. This cost is high and does not provide enough material for any meaningful synthetic investigation. As of June 2020, this compound was no longer commercially available on Sigma-Aldrich. Please see the Sigma-Aldrich commercial page concerning the availability of $(1 R, 2 S)$-norephedrine.

https://www.sigmaaldrich.com/catalog/search?term=\%281R\%2C2S\%29norephedrine\&interface $=\mathrm{All} \& \mathrm{~N}=0 \& \operatorname{mode}=$ match $\% 20$ partialmax $\&$ lang $=$ en $\&$ region $=$ US\&focus $=$ product

68. Abdel-Magid, A. F.; Carson, K. G.; Harris, B. D.; Maryanoff, C. A.; Shah, R. D. J. Org. Chem. 1996, 61, 3849-3862.

69. Abdel-Magid, A. F.; Mehrman, S. J. Org. Proc. Res. Dev. 2006, 10, 971-1031.

70. Borikar, S. P.; Paul, V. Synth. Commun. 2010, 40, 654-660.

71. N-Nitrosamines are known carcinogens that occur in common foods and as synthetic intermediates in research laboratories. The N-Nitrosamines synthesized in this thesis were handled with care and immediately reduced to the corresponding hydrazine. Please see the following article for a discussion on the chemical and carcinogenic properties of N-nitrosamines. Park, J.; Seo, J.; Lee, J.; Kwon, H. Toxicology Res. 2015, 31, 279-288. 
72. Cronyn, M. W.; Nakagawa, T. W. J. Am. Chem. Soc. 1952, 74, 3693-3694.

73. Poirier, R. H.; Benington, F. J. Am. Chem. Soc. 1952, 79, 3192.

74. Schueler, F. W.; Hanna, C. J. Am. Chem. Soc. 1951, 73, 4996.

75. Chaudhary, P.; Gupta, S.; Sureshbahu, P.; Sabiah, S.; Kandasamy, J. Green Chem. 2016, $18,6215-6221$.

76. Leise, A. R.; Comas, N.; Harrison, D.; Patel, D.; Whitemiller, E. G.; Wilson, J.; Timms, J.; Golightly, I.; Hamaker, C. G.; Hitchcock, S. R. Tetrahedron Lett. 2002, 4, 31113114.

77. Yagi, K.; Turitani, T.; Shinokubo, H.; Oshima, K. Tetrahedron: Asymmetry 2017, 28, 1154-1162.

78. Dahiya, A.; Sahoo, A. K.; Alam, T.; Patel, B. K. Chem. Asian J. 2019, 14, 4454-4492. 
APPENDIX A: EXPERIMENTALS 
General Remarks: Chemical reagents and solvents were purchased from commercial vendors and used without further purification. All reactions were conducted in flame-dried or oven dried glassware under a nitrogen atmosphere. Solvents were removed by rotary evaporation and further dried by a Welch DryFast mechanical pump. All ${ }^{1} \mathrm{H}$ and ${ }^{13} \mathrm{C}$ NMR spectra were recorded in deuterated chloroform $\left(\mathrm{CDCl}_{3}\right)$ using an NMR spectrometer operating at 500 and $400 \mathrm{MHz}$ for ${ }^{1} \mathrm{H}$ NMR and operating at 125 and $100 \mathrm{MHz}$ for ${ }^{13} \mathrm{C}$ NMR. Chemical shifts were reported in parts per million ( $\delta$ scale) and coupling constant ( $J$ values) are listed in Hertz $(\mathrm{Hz})$. Tetramethylsilane (TMS) was used as internal standard $(\delta=0 \mathrm{ppm})$. Major isomers were reported except otherwise stated. $\mathrm{OH}$ and $\mathrm{NH}$ peaks were reported except when not observed. Infrared spectra were reported in reciprocal centimeters $\left(\mathrm{cm}^{-1}\right)$ and were measured in nujol mull, regular chloroform or as a neat liquid. Melting points were recorded on a Mel-Temp apparatus and were uncorrected. All polarimetric experiments were carried out using a Jasco P-2000 polarimeter. 


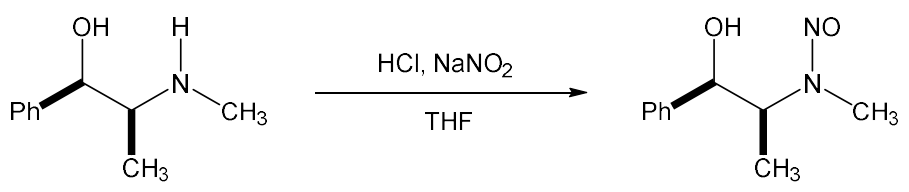

52

53

N-nitrosamine of $(\mathbf{1} \boldsymbol{R}, \mathbf{2 S})$-Ephedrine (53): The $(1 R, 2 S)$ - ephedrine substrate (52) (20.00 g, $121.0 \mathrm{mmol}$ ) was placed in a $250 \mathrm{~mL}$ round bottom flask and dissolved in tetrahydrofuran (THF) (40 mL). This was followed with the addition of an aqueous hydrochloric acid (51 mL, $2.74 \mathrm{M}$, $139 \mathrm{mmol})$ and sodium nitrite $(9.60 \mathrm{~g}, 139 \mathrm{mmol})$ and the reaction was left stirring for $24 \mathrm{~h}$. The mixture was then made basic through dilution with saturated aqueous solution of $\mathrm{NaHCO}_{3}$ and then extracted with ethyl acetate $(75 \mathrm{~mL})$ followed by brine wash. The organic product was dried with $\mathrm{MgSO}_{4}$, filtered under gravity and solvents-removed under reduced pressure to yield 22.21 $\mathrm{g}(95 \%)$ of the target molecule as a yellow solid: MP: $92-94{ }^{\circ} \mathrm{C} .{ }^{1} \mathrm{H}$ NMR $\left(\mathrm{CDCl}_{3}\right): \delta=1.47(\mathrm{~d}, J$ $=7.0 \mathrm{~Hz}, 3 \mathrm{H}), 2.40(\mathrm{bs}, 1 \mathrm{H}), 2.96(\mathrm{~s}, 3 \mathrm{H}), 4.69$ (quintet, $J=7.0 \mathrm{~Hz}, 1 \mathrm{H}), 5.07(\mathrm{~d}, J=5.1 \mathrm{~Hz}$, 1H), 7.35-7.37 (m, 5H). ${ }^{13} \mathrm{C} \mathrm{NMR}\left(\mathrm{CDCl}_{3}\right): \delta=13.4,31.4,65.3,74.6,126.4,128.4,128.8$, 141.0. IR (KBr): 3374, 2983, $1452 \mathrm{~cm}^{-1}$. 


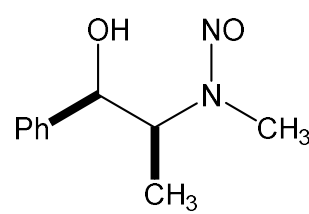

53

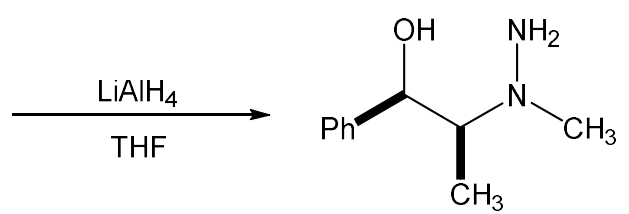

54

$(1 R, 2 S)-2-m e t h y l a m i n o-N$-amino-1-phenyl-1-propanol (54): The reducing agent lithium aluminum hydride $\left(\mathrm{LiAlH}_{4}\right)(12.3 \mathrm{~g}, 325 \mathrm{mmol})$ and the solvent tetrahydrofuran (THF) $(300 \mathrm{~mL})$ were placed in a flame-dried, nitrogen-purged, 5 L, 3-neck round bottom flask set up with an addition funnel and a condenser. The mixture was then heated under reflux. This was followed with the addition of the nitrosamine substrate (53) $(21.0 \mathrm{~g}, 108 \mathrm{mmol})$ which was pre-dissolved in THF. The addition was carried out via the addition funnel over a period of $30 \mathrm{~min}$. The reaction mixture was thereafter maintained under reflux for another $5 \mathrm{hrs}$. after which it was cooled to room temperature. Once at room temperature, $\mathrm{NaOH}(6 \mathrm{M})$ was carefully added to the reaction vessel to consume any unreacted $\mathrm{LiAlH}_{4}$. The reaction was then extracted with ethyl acetate $(150 \mathrm{~mL})$ and washed with brine $(100 \mathrm{~mL})$. The recovered organic product was then dried with $\mathrm{MgSO}_{4}$, filtered under gravity and solvents-removed under reduced pressure to yield $18.0 \mathrm{~g}(93 \%)$ of the target molecule as a yellow viscous oil: ${ }^{1} \mathrm{H} \mathrm{NMR}\left(\mathrm{CDCl}_{3}\right): \delta=0.83(\mathrm{~d}, J=$ $6.7 \mathrm{~Hz}, 3 \mathrm{H}), 2.59$ (s, 3H), $2.76(\mathrm{dq}, J=6.7,1.5 \mathrm{~Hz}, 1 \mathrm{H}), 5.21(\mathrm{~s}, 1 \mathrm{H}), 7.21-7.39(\mathrm{~m}, 5 \mathrm{H}) . \mathrm{IR}$ (KBr): 2978, 1619, $1046 \mathrm{~cm}^{-1}$. 
<smiles>C[C@H]([C@H](O)c1ccccc1)N(C)N</smiles>

54

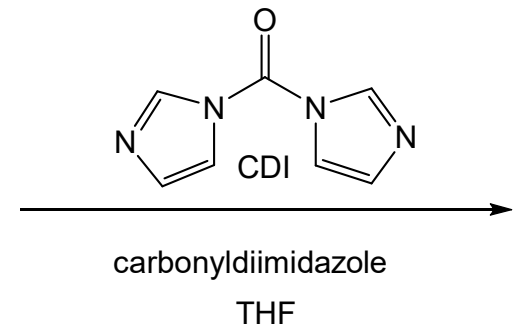

THF

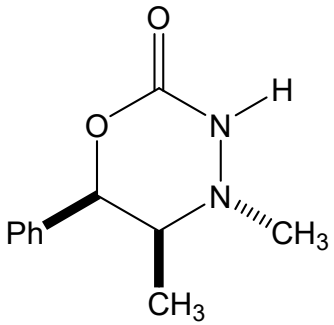

34

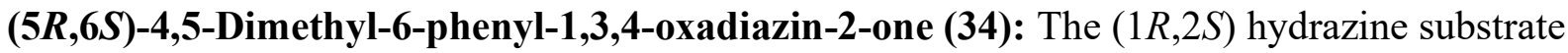
(54) (14.3 g, $79.4 \mathrm{mmol})$ was placed in a flame-dried, nitrogen-purged $500 \mathrm{~mL}$ round bottom flask and dissolved in THF (200 mL). To the solution was added $p$-toluene sulfonic acid monohydrate $(15.1 \mathrm{~g}, 87.4 \mathrm{mmol})$ followed with the addition of 1,1-carbonyldiimidazole $(14.2 \mathrm{~g}$, $87.4 \mathrm{mmol})$. The resulting mixture was heated under reflux for three hours after which it was cooled to room temperature, followed with addition of an aqueous solution of sodium bicarbonate $(50 \mathrm{~mL})$. The reaction was then extracted with ethyl acetate $(50 \mathrm{~mL})$ and washed with brine $(50 \mathrm{~mL})$. The recovered organic product was dried with $\mathrm{MgSO}_{4}$, filtered under gravity and solvents-removed by rotary evaporation to yield $12.1 \mathrm{~g}(74 \%)$ of the target molecule as a white solid: MP: $118-120{ }^{\circ} \mathrm{C} .{ }^{1} \mathrm{H}$ NMR $\left(\mathrm{CDCl}_{3}\right): \delta=1.02(\mathrm{~d}, J=7.0 \mathrm{~Hz}, 3 \mathrm{H}), 3.03(\mathrm{~s}, 3 \mathrm{H}), 3.44$ (dq, $J=4.3,7.0 \mathrm{~Hz}, 1 \mathrm{H}), 6.05(\mathrm{~d}, J=4.3 \mathrm{~Hz}, 1 \mathrm{H}), 7.13-7.15(\mathrm{~m}, 1 \mathrm{H}), 7.24-7.26(\mathrm{~m}, 2 \mathrm{H}), 7.29-$ $7.30(\mathrm{~m}, 2 \mathrm{H}) .{ }^{13} \mathrm{C}$ NMR: $\delta=11.7,46.6,57.0,74.2,125.3,128.0,128.6,136.2,152.2 . \mathrm{IR}(\mathrm{KBr})$ : 3228, 2943, $1686 \mathrm{~cm}^{-1}$. ESI HRMS for $\mathrm{C}_{11} \mathrm{H}_{14} \mathrm{~N}_{2} \mathrm{NaO}_{2}{ }^{+}$: calcd $\left(\mathrm{M}+\mathrm{Na}^{+}\right) 229.0947$, found 229.0950. 
<smiles>CC1C(c2ccccc2)OC(=O)NN1C</smiles>

34

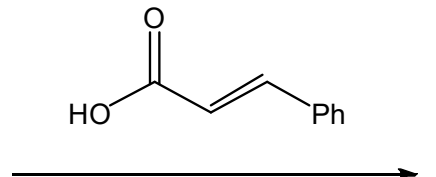

EDC, DMAP, $\mathrm{CH}_{2} \mathrm{Cl}_{2}$<smiles>CC1C(c2ccccc2)OC(=O)N(C(=O)/C=C/c2ccccc2)N1C</smiles>

43

(5S,6R)-3-trans-Cinnamoyl-N4-p-methoxybenzyl-4-methyl-6-phenyl-1,3,4-oxadiazinone

(43): To a flame dried, nitrogen purged $250 \mathrm{~mL}$ round bottom flask was added trans-cinnamic acid (1.29 g, $8.72 \mathrm{mmol})$ and dissolved in anhydrous dichloromethane (16 $\mathrm{mL})$. This was followed with the addition of the coupling agent 1-ethyl-3-(3-dimethylaminopropyl) carbodiimide (EDC) $(1.671 \mathrm{~g}, 8.72 \mathrm{mmol})$, the 4-dimethylaminopyridine (DMAP) catalyst $(0.134 \mathrm{~g}, 1.09 \mathrm{mmol})$ and the oxadiazinone substrate $(0.900 \mathrm{~g}, 4.36 \mathrm{mmol})$, sequentially and left stirring at room temperature for 16 hours. The reaction was then diluted with dichloromethane $(80 \mathrm{~mL})$ and washed with $1 \mathrm{M} \mathrm{HCl}(20 \mathrm{~mL}), 1 \mathrm{M} \mathrm{NaOH}(20 \mathrm{~mL})$ (twice) followed by brine (20 $\mathrm{mL}$ ) wash. The organic layer thus recovered was dried over magnesium sulfate, gravity filtered, and solvent removed under reduced pressure. The crude product obtained was purified by flash column chromatography (hexane: ethyl acetate, $70: 30)$ to yield the title compound (1.034 g, $71 \%$ ) as a white solid: MP: $125-128{ }^{\circ} \mathrm{C} .{ }^{1} \mathrm{H} \mathrm{NMR}\left(\mathrm{CDCl}_{3}\right): \delta=0.93(\mathrm{~d}, J=7.0 \mathrm{~Hz}, 3 \mathrm{H}), 3.08(\mathrm{~s}$, 3H), $3.48(\mathrm{dq}, J=6.9,4.6 \mathrm{~Hz}, 1 \mathrm{H}), 6.12(\mathrm{~d}, J=4.6 \mathrm{~Hz}, 1 \mathrm{H}), 7.34-7.38(\mathrm{~m}, 3 \mathrm{H}), 7.41-7.45(\mathrm{~m}$, 5H), 7.61-7.64 (m, 3H), $7.88(\mathrm{~d}, J=15.6 \mathrm{~Hz}, 1 \mathrm{H}) .{ }^{13} \mathrm{C} \mathrm{NMR}\left(\mathrm{CDCl}_{3}\right): \delta=12.7,43.8,56.9,77.9$, 119.0, 125.0, 128.2, 128.4, 128.7, 128.9, 130.5, 134.8, 135.8, 145.8, 148.1, 166.6. IR $\left(\mathrm{CHCl}_{3}\right)$ : 1730, 1704, 1623, 1267, 1197, 724, $703 \mathrm{~cm}^{-1}$. ESI HRMS for $\mathrm{C}_{20} \mathrm{H}_{20} \mathrm{~N}_{2} \mathrm{NaO}_{3}{ }^{+}$: calcd $\left(\mathrm{M}+\mathrm{Na}^{+}\right)$ 359.1366, found 359.1366. 


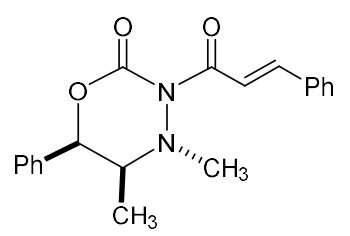

43

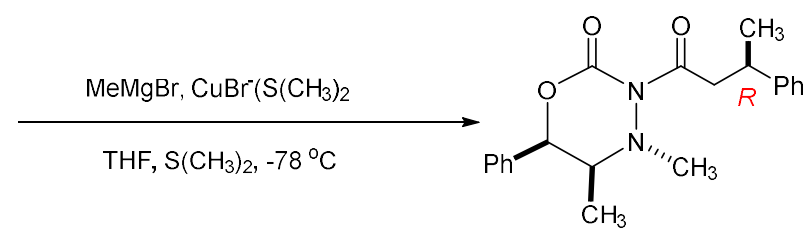

$59 a$

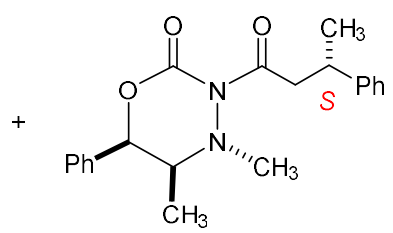

$59 b$

(5S,6R)-4-para-Methoxybenzyl-4-methyl-6-phenyl-3-(3'-phenylbutanoyl)-1,3,4-

oxadiazinone (59): To a $100 \mathrm{~mL}$ flame dried, nitrogen purged three-neck round bottomed flask was added copper bromide dimethyl sulfide complex (0.933 g $4.54 \mathrm{mmol})$, tetrahydrofuran (THF) ( $5 \mathrm{~mL}$ ) by syringe and dimethyl sulfide solvent $(5 \mathrm{~mL})$ by syringe, one after the other. The reaction was then cooled to a temperature of $-78^{\circ} \mathrm{C}$ in a dry ice/ ethanol bath. Methyl magnesium bromide $(1.51 \mathrm{~mL}, 4.54 \mathrm{mmol})$ was then carefully added to the solution by syringe and left to stir for 45 minutes at $-78^{\circ} \mathrm{C}$. The $\mathrm{N}_{3}$-cinnamoyloxadiaxinone (43) substrate $(0.509 \mathrm{~g}$, $1.51 \mathrm{mmol})$ was dissolved in THF $(6 \mathrm{~mL})$ and then added by dropwise addition to the reaction vessel through an addition funnel. The reaction was left stirring for 17 hours while it gradually warmed up to room temperature. The reaction was then diluted with ethyl acetate $(80 \mathrm{~mL})$ and washed with $1 \mathrm{M} \mathrm{NaOH}(20 \mathrm{~mL}), 1 \mathrm{M} \mathrm{HCl}(20 \mathrm{~mL})$ and brine solution $(20 \mathrm{~mL})$. The recovered organic layer was dried with magnesium sulfate, filtered under gravity and solvent removed under high vacuum. The crude product obtained was purified by flash column chromatography (Hexane: ethyl acetate, $70: 30)$ to yield $0.348 \mathrm{~g}(65 \%)$ of the titled compound as a colorless viscous oil. Only the major isomer is reported: ${ }^{1} \mathrm{H} \mathrm{NMR}\left(\mathrm{CDCl}_{3}\right): \delta=0.79(\mathrm{~d}, J=7.0 \mathrm{~Hz}, 3 \mathrm{H})$, $1.32(\mathrm{~d}, J=6.8 \mathrm{~Hz}, 3 \mathrm{H}), 2.82(\mathrm{~s}, 3 \mathrm{H}), 3.11(\mathrm{dd}, J=7.6,16.4 \mathrm{~Hz}, 1 \mathrm{H}), 3.27-3.49(\mathrm{~m}, 3 \mathrm{H}), 5.99$ (d, $J=4.4 \mathrm{~Hz}, 1 \mathrm{H}), 7.15-7.20(\mathrm{~m}, 1 \mathrm{H}), 7.25-7.29(\mathrm{~m}, 6 \mathrm{H}), 7.31-7.34(\mathrm{~m}, 1 \mathrm{H}), 7.37-7.41(\mathrm{~m}, 2 \mathrm{H})$.

${ }^{13} \mathrm{C} \mathrm{NMR}\left(\mathrm{CDCl}_{3}\right): \delta=12.4,21.8,36.2,43.3,45.9,56.8,124.9,126.3,127.1,128.2,128.4$, 128.7, 135.7, 146.0, 148.4, 172.6. IR $\left(\mathrm{CHCl}_{3}\right): 1778,1724,1257,1137,744,700 \mathrm{~cm}^{-1}$. ESI HRMS for $\mathrm{C}_{21} \mathrm{H}_{24} \mathrm{~N}_{2} \mathrm{NaO}_{3}{ }^{+}$: calcd $\left(\mathrm{M}+\mathrm{Na}^{+}\right) 375.1679$, found 375.1678 . 


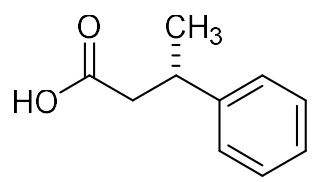

$60 a$

(S)-(+)-3-Phenylbutanoic acid (60a): To a racemic mixture of $(S)-(+)-3$-Phenylbutanoic acid (60a) and $(R)-(+)-3$-Phenylbutanoic acid (60b) $(5.24 \mathrm{~g}, 31.9 \mathrm{mmol})$ in a $250 \mathrm{~mL}$ beaker was added the chiral amine (S)-(-)-1-phenylethylamine (61) (3.90 g, $31.9 \mathrm{mmol})$, ethanol (100\%) (13 $\mathrm{mL})$ and deionized water $(15 \mathrm{~mL})$. The mixture was stirred gently until a homogeneous solution was obtained. The solution was then left to stand at room temperature for about 15 minutes to allow the formation of the carboxylate diastereomeric crystal salt (62b). The crystals formed (4.16 g) was recovered by vacuum filtration. The recovered crystals were subjected to second recrystallization by dissolution in ethanol and deionized water solution (15 $\mathrm{mL}$ each) by means of heating and spinning at $50{ }^{\circ} \mathrm{C}$ on a rotary evaporator. The homogenous solution was allowed to stand at room temperature till crystals were reformed. The crystals $(3.15 \mathrm{~g})$ were again collected by vacuum filtration. The carboxylate salt was then extracted with diethyl ether ( 80 $\mathrm{mL})$ and aqueous hydrochloric acid $(1 \mathrm{M})(50 \mathrm{~mL})$ to yield $1.26 \mathrm{~g}(48 \%)$ of the $(S)-(+)-3-$ Phenylbutanoic acid (60a) as a colorless liquid. ${ }^{1} \mathrm{H}$ NMR $\left(\mathrm{CDCl}_{3}\right): \delta=1.30(\mathrm{~d}, J=6.9 \mathrm{~Hz}, 3 \mathrm{H})$, $2.58(\mathrm{dd}, J=8.3,15.6 \mathrm{~Hz}, 1 \mathrm{H}), 2.67(\mathrm{dd}, J=6.9,15.6 \mathrm{~Hz}, 1 \mathrm{H}), 3.27$ (sxt, $J=7.5,14.7 \mathrm{~Hz}, 1 \mathrm{H})$, 7.19-7.23 (m, 3H), 7.29-7.32 (m, 2H); ${ }^{13} \mathrm{C} \mathrm{NMR}\left(\mathrm{CDCl}_{3}\right): \delta=21.9,36.2,42.7,126.5,126.7$ 128.6 145.5, 178.9; IR (neat): 2970, 1706, 1296, 763, $700 \mathrm{~cm}^{-1}$ ESI HRMS for $\mathrm{C}_{11} \mathrm{H}_{14} \mathrm{~N}_{2} \mathrm{NaO}_{2}{ }^{+}$: calcd $\left(\mathrm{M}+\mathrm{Na}^{+}\right)$187.0730, found 187.0730. 


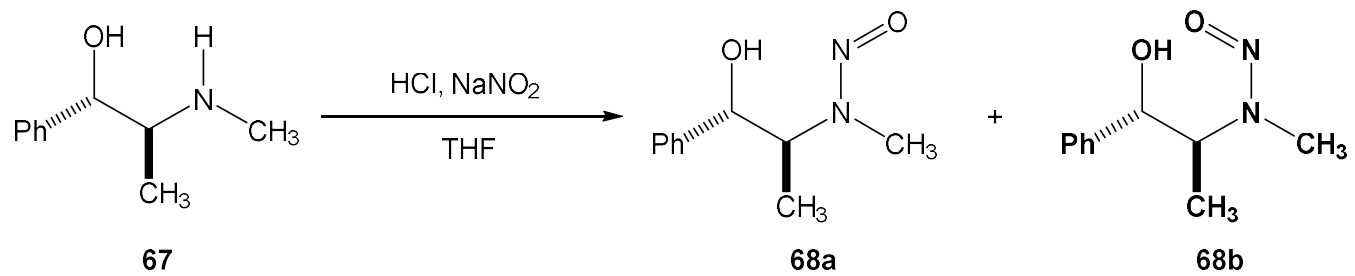

N-nitrosamine of $(\mathbf{1} S, 2 S)$-pseudoephedrine (68): The $(1 S, 2 S)$-pseudoephedrine substrate (20.00 g, $121.0 \mathrm{mmol}$ ) was placed in a $250 \mathrm{~mL}$ round bottom flask together with Tetrahydrofuran (THF) (50 mL). This was followed with the addition of an aqueous hydrochloric acid $(50.8 \mathrm{~mL}$, 2.74 M, $139 \mathrm{mmol})$ and sodium nitrite $(9.60 \mathrm{~g}, 139 \mathrm{mmol})$ and the reaction was left stirring for 24h. The mixture was then made basic through dilution with saturated aqueous solution of $\mathrm{NaHCO}_{3}$ and then extracted with ethyl acetate $(75 \mathrm{~mL})$ followed by brine wash $(25 \mathrm{~mL})$. The organic product was dried with $\mathrm{MgSO}_{4}$, filtered under gravity and solvents-removed under reduced pressure to yield $22.9 \mathrm{~g}(97 \%)$ of the target molecule as a yellow solid after recrystallization (EtOAc-hexanes, 1:1): MP: $85-86{ }^{\circ} \mathrm{C} .{ }^{1} \mathrm{H} \mathrm{NMR}\left(\mathrm{CDCl}_{3}\right): \delta=1.29(\mathrm{~d}, J=6.6$ $\mathrm{Hz}, 3 \mathrm{H}), 2.44(\mathrm{bs}, 1 \mathrm{H}), 3.07(\mathrm{~s}, 3 \mathrm{H}), 4.75-4.86(\mathrm{~m}, 2 \mathrm{H}), 7.32-7.41(\mathrm{~m}, 5 \mathrm{H}) .{ }^{13} \mathrm{C} \mathrm{NMR}\left(\mathrm{CDCl}_{3}\right): \delta$ $=16.0,30.2,65.1,76.4,126.8,128.6,128.9,140.4 . \mathrm{IR}(\mathrm{KBr}): 3480,3032,1465,1268,820,721$ $\mathrm{cm}^{-1}$. 
<smiles>C[C@H]([C@H](O)[PbH])N(C)[N+](=O)[O-]</smiles>

68

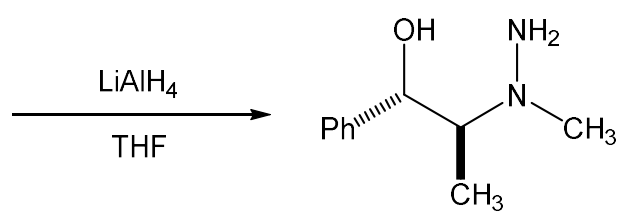

69

$(1 S, 2 S)-2-m e t h y l a m i n o-N$-amino-1-phenyl-1-propanol (69): The reducing agent lithium aluminum hydride $\left(\mathrm{LiAlH}_{4}\right)(13.4 \mathrm{~g}, 353 \mathrm{mmol})$ and the solvent tetrahydrofuran (THF) (400 mL) were placed in a flame-dried, nitrogen-purged, 5 L, 3-neck round bottom flask set up with an addition funnel and a condenser. The mixture was then heated under reflux. This was followed with the addition of the nitrosamine substrate $(\mathbf{6 8})(22.9 \mathrm{~g}, 118 \mathrm{mmol})$ which was pre-dissolved in THF. The addition was carried out via the addition funnel over a period of $30 \mathrm{~min}$. The reaction mixture was thereafter maintained under reflux for another $5 \mathrm{hrs}$. after which it was cooled to room temperature. Once at room temperature, $\mathrm{NaOH}(6 \mathrm{M})$ was carefully added to the reaction vessel to consume any unreacted $\mathrm{LiAlH}_{4}$. The reaction was then extracted with ethyl acetate $(150 \mathrm{~mL})$ and washed with brine $(100 \mathrm{~mL})$. The recovered organic product was then dried with $\mathrm{MgSO}_{4}$, filtered under gravity and solvents-removed under reduced pressure to yield $21.1 \mathrm{~g}(99 \%)$ of the target molecule as a yellow viscous oil: ${ }^{1} \mathrm{H} \mathrm{NMR}\left(\mathrm{CDCl}_{3}\right): \delta=0.79(\mathrm{~d}, J=$ $6.6 \mathrm{~Hz}, 3 \mathrm{H}), 2.58(\mathrm{~s}, 3 \mathrm{H}), 2.63-2.69(\mathrm{~m}, 1 \mathrm{H}), 4.42(\mathrm{~d}, J=9.2 \mathrm{~Hz}, 1 \mathrm{H}), 7.27-7.38(\mathrm{~m}, 5 \mathrm{H}) . \mathrm{IR}$ (KBr): 3333, 2975, 754, $701 \mathrm{~cm}^{-1}$. 
<smiles>C[C@H]([C@H](O)c1ccccc1)N(C)N</smiles>

69

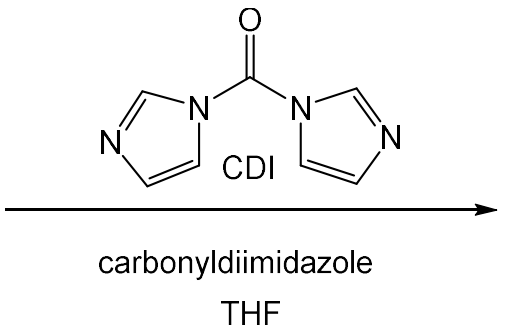<smiles>C[C@H]1[C@H](c2ccccc2)OC(=O)NN1C</smiles>

70

(5S,6S)-4,5-Dimethyl-6-phenyl-1,3,4-oxadiazin-2-one (70): The $(1 S, 2 S)$ hydrazine substrate (69) $(2.86 \mathrm{~g}, 15.9 \mathrm{mmol})$ was placed in a flame-dried, nitrogen-purged $100 \mathrm{~mL}$ round bottom flask and dissolved in THF (100 mL). To the solution was added $p$-toluene sulfonic acid monohydrate $(3.02 \mathrm{~g}, 15.88 \mathrm{mmol})$ followed with the addition of 1,1-carbonyldiimidazole (3.09 g, $19.1 \mathrm{mmol}$ ). The resulting mixture was heated under reflux for three hours after which it was cooled to room temperature and an aqueous solution of sodium bicarbonate $(50 \mathrm{~mL})$ was added. The reaction was then extracted with ethyl acetate $(50 \mathrm{~mL})$ and washed with brine $(50 \mathrm{~mL})$. The recovered organic product was dried with $\mathrm{MgSO}_{4}$, filtered under gravity and solvents-removed by rotary evaporation to yield $2.40 \mathrm{~g}(74 \%)$ of the target molecule as a white solid after chromatography purification: MP: $97-98{ }^{\circ} \mathrm{C} .[\alpha]^{23}{ }_{\mathrm{D}}+30.1^{\mathrm{o}}(\mathrm{THF}) .{ }^{1} \mathrm{H}$ NMR $\left(\mathrm{CDCl}_{3}\right): \delta=0.96(\mathrm{~d}$, $J=6.8 \mathrm{~Hz}, 3 \mathrm{H}), 2.69(\mathrm{~s}, 3 \mathrm{H}), 3.22(\mathrm{dq}, J=6.8,9.9 \mathrm{~Hz}, 1 \mathrm{H}), 5.25(\mathrm{~d}, J=9.9 \mathrm{~Hz}, 1 \mathrm{H}), 7.31-7.34$ (m, 3H), 7.36-7.41 (m, 3H), $7.65(\mathrm{~s}, 1 \mathrm{H}) .{ }^{13} \mathrm{C} \mathrm{NMR}(\mathrm{CDCl} 3): \delta=14.3,40.0,58.8,80.7,127.1$ 128.7, 129.0, 136.6, 153.0. IR (KBr): 3240, 1699, 755, $700 \mathrm{~cm}^{-1}$. 
<smiles>CC1[C@H](c2ccccc2)OC(=O)NN1C</smiles>

70

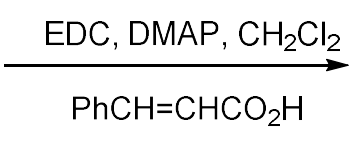

71

(4S,5S)-3-trans-Cinnamoyl-4,5-dimethyl-6-phenyl-1,3,4-oxadiazinone (71): trans-Cinnamic acid (2.58 g, $17.4 \mathrm{mmol})$ was added to a flame dried, nitrogen purged $250 \mathrm{~mL}$ round bottom flask and dissolved in anhydrous dichloromethane $(16 \mathrm{~mL})$. This was followed with a sequential addition of the coupling agent 1-ethyl-3-(3-dimethylaminopropyl) carbodiimide (EDC) (3.34 g, $17.4 \mathrm{mmol})$, the 4-dimethylaminopyridine (DMAP) catalyst $(0.268 \mathrm{~g}, 2.18 \mathrm{mmol})$ and the oxadiazinone substrate $(1.80 \mathrm{~g}, 8.72 \mathrm{mmol})$. The reaction was then left stirring for 16 hours at room temperature after which the reaction was diluted with dichloromethane $(80 \mathrm{~mL})$ and washed with $1 \mathrm{M} \mathrm{HCl}(20 \mathrm{~mL}), 1 \mathrm{M} \mathrm{NaOH}(20 \mathrm{~mL})$ (twice) followed by brine $(20 \mathrm{~mL})$ wash. The organic layer thus recovered was dried over magnesium sulfate, gravity filtered, and solvent removed under reduced pressure. The crude product obtained was purified by flash column chromatography (hexane: ethyl acetate, $75: 25)$ to yield the title compound $(1.74 \mathrm{~g}, 59 \%)$ as a white fluffy solid. MP: $47-50{ }^{\circ} \mathrm{C} .{ }^{1} \mathrm{H} \mathrm{NMR}\left(\mathrm{CDCl}_{3}\right): \delta=1.21(\mathrm{~d}, J=6.8 \mathrm{~Hz}, 3 \mathrm{H}), 2.91(\mathrm{~s}, 3 \mathrm{H})$, $3.42(\mathrm{dq}, J=6.8,10.4 \mathrm{~Hz}, 1 \mathrm{H}) .5 .30(\mathrm{~d}, J=9.8 \mathrm{~Hz}, 1 \mathrm{H}), 7.36-7.38(\mathrm{~m}, 2 \mathrm{H}), 7.42-7.45(\mathrm{~m}, 6 \mathrm{H})$, $7.53(\mathrm{~d}, J=15.7,1 \mathrm{H}), 7.62-7.64(\mathrm{~m}, 1 \mathrm{H}), 7.89(\mathrm{~d}, J=15.7 \mathrm{~Hz}, 1 \mathrm{H}) .{ }^{13} \mathrm{C} \mathrm{NMR}\left(\mathrm{CDCl}_{3}\right): \delta=15.4$, $38.7,61.0,84.1,118.7,126.9,128.4,128.9,129.0,129.3,130.5,134.8,136.0,145.8,149.5$, 165.8. IR $\left(\mathrm{CHCl}_{3}\right): 1704,1626,1577,1204,1128,1045,700,666 \mathrm{~cm}^{-1}$. ESI HRMS for $\mathrm{C}_{20} \mathrm{H}_{20} \mathrm{~N}_{2} \mathrm{NaO}_{3}{ }^{+}$: calcd $\left(\mathrm{M}+\mathrm{Na}^{+}\right)$359.1366, found 359.1358. 

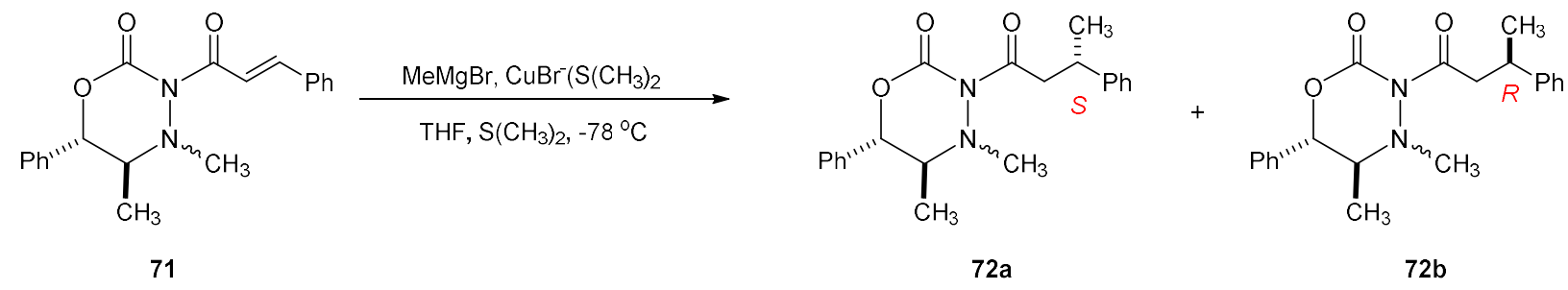

\section{(5S,6R)-4-para-Methoxybenzyl-4-methyl-6-phenyl-3-(3'-phenylbutanoyl)-1,3,4-}

oxadiazinone (72): To a $100 \mathrm{~mL}$ flame dried, nitrogen purged three-neck round bottomed flask was added copper bromide dimethyl sulfide complex (1.00 g $4.87 \mathrm{mmol})$, tetrahydrofuran (THF) $(5 \mathrm{~mL})$ by syringe and dimethyl sulfide solvent $(5 \mathrm{~mL})$ by syringe, one after the other. The reaction was then cooled to a temperature of $-78{ }^{\circ} \mathrm{C}$ in a dry ice/ ethanol bath. Methyl magnesium bromide (1.62 $\mathrm{mL}, 4.87 \mathrm{mmol})$ was then carefully added to the solution by syringe and left to stir for 45 minutes at $-78{ }^{\circ} \mathrm{C}$. The $\mathrm{N}_{3}$-cinnamoyloxadiaxinone (29) substrate (0.546 g, $\left.1.62 \mathrm{mmol}\right)$ was dissolved in THF (6 mL) and then added by dropwise addition to the reaction vessel through an addition funnel. The reaction was left stirring for 17 hours while it gradually warmed up to room temperature. The reaction was then diluted with ethyl acetate $(80 \mathrm{~mL})$ and washed with $1 \mathrm{M}$ $\mathrm{NaOH}(20 \mathrm{~mL}), 1 \mathrm{M} \mathrm{HCl}(20 \mathrm{~mL})$ and brine solution $(20 \mathrm{~mL})$. The recovered organic layer was dried with magnesium sulfate, filtered under gravity and solvent removed under high vacuum. The crude product obtained was purified by flash column chromatography (Hexane: ethyl acetate, $70: 30)$ to yield $0.451 \mathrm{~g}(79 \%)$ of the titled compound as a colorless oil. ${ }^{1} \mathrm{H}$ NMR $\left(\mathrm{CHCl}_{3}\right): \delta=0.96(\mathrm{~d}, J=6.8 \mathrm{~Hz}, 3 \mathrm{H}), 1.29(\mathrm{~d}, J=6.9 \mathrm{~Hz}, 3 \mathrm{H}), 2.62(\mathrm{~s}, 3 \mathrm{H}), 2.90-3.04(\mathrm{~m}, 2 \mathrm{H})$, 3.25-3.29 (dd, $J=7.7,15.7 \mathrm{~Hz}, 1 \mathrm{H}), 3.35(\mathrm{sxt}, J=7.1 \mathrm{~Hz}, 1 \mathrm{H}), 5.1$ (bs, 1H), 7.13-7.18 (m, 4H), 7.21-7.24 (m, 3H), 7.31-7.33 (m, 3H). ${ }^{13} \mathrm{C} \mathrm{NMR}\left(\mathrm{CHCl}_{3}\right): \delta=15.6,22.0,36.8,36.9,44.7,45.1$ $83.9,126.5,126.9,127.1,128.5,128.6,128.9,129.3,135.9,145.9,171.9$. IR (neat): 1781, 1728, 
1211, 1126, 760, $700 \mathrm{~cm}^{-1}$. ESI HRMS for $\mathrm{C}_{21} \mathrm{H}_{24} \mathrm{~N}_{2} \mathrm{NaO}_{3}{ }^{+}$: calcd $\left(\mathrm{M}+\mathrm{Na}^{+}\right) 375.1679$, found 375.1673. 


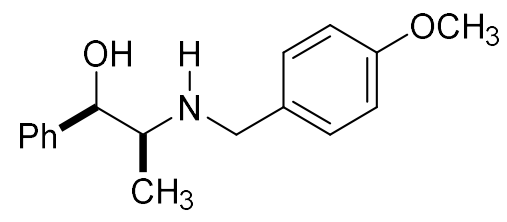

75

$(1 R, 2 S)-N$-para-Methoxybenzyl-norephedrine (75): To a $1000 \mathrm{~mL}$ round bottom flask containing $(1 R, 2 S)$-norephedrine $(10.0 \mathrm{~g}, 66.1 \mathrm{mmol})$ was added para-anisaldehyde $(8.8 \mathrm{~mL}, 72$ mmol) and $100 \%$ methanol $(100 \mathrm{~mL})$ to make a solution. To the solution was added two scoops of $\mathrm{MgSO}_{4}$ and stirred thoroughly, and the reaction mixture was stirred overnight. At which point $\mathrm{NaBH}_{4}(3.77 \mathrm{~g}, 99.2 \mathrm{mmol})$ was added to the reaction and stirred for another for 2 hours, after which $\mathrm{NaOH}(50 \mathrm{~mL}, 1 \mathrm{M})$ was added to the reaction mixture and stirred for 1 hour. After which most of the ethanol was removed in vacuo and the resulting slurry was reconstituted with 200 $\mathrm{mL}$ ethyl acetate and the organic layer was collected and washed with $50 \mathrm{~mL}$ deionized water, 50 $\mathrm{mL}$ brine, dried over $\mathrm{MgSO}_{4}$, filtered and solvents removed in vacuo. The crude product was used without further purification in the next step. 


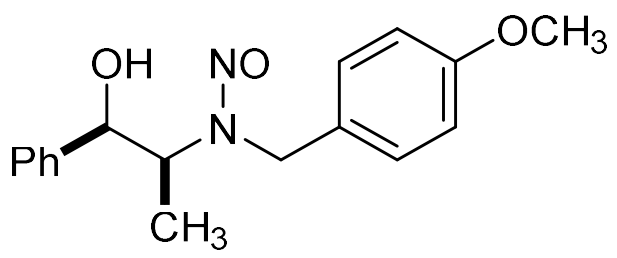

76

$N$-((1R,2S)-2-para-Methoxybenzyl-N-nitrosamino)-1-phenyl-1-propanol (76): To the 1000 $\mathrm{mL}$ round bottom flask containing crude protected $(1 R, 2 S)$-norephedrine (2.1) was added, THF $(80 \mathrm{~mL})$ followed by aqueous solution of hydrochloric acid $(2 \mathrm{M}, 50 \mathrm{~mL}, 100 \mathrm{mmol})$ and stirred to make a solution. To the solution was added $\mathrm{NaNO}_{2}(4.6 \mathrm{~g}, 66.1 \mathrm{mmol})$ slowly in one portion and allowed to stir overnight. The reaction was then extracted in $200 \mathrm{~mL}$ ethyl acetate and washed with $50 \mathrm{~mL} 1 \mathrm{M} \mathrm{HCl}, 50 \mathrm{~mL}$ brine, dried over $\mathrm{MgSO}_{4}$, filtered and solvent removed under high vacuum. The crude product obtained was purified by flash column chromatography (Hexane: ethyl acetate, 70:30) to give $18.9 \mathrm{~g} \mathrm{(96 \% )}$ of the title compound (a mixture of diastereomers), as a yellow oil. ${ }^{1} \mathrm{H}$ NMR $\left(\mathrm{CDCl}_{3}\right): \delta=1.46(\mathrm{~d}, J=6.9 \mathrm{~Hz}, 3 \mathrm{H}), 3.79(\mathrm{~s}, 3 \mathrm{H})$, $4.26(\mathrm{dq}, J=5.1,6.9 \mathrm{~Hz}, 1 \mathrm{H}), 4.37(\mathrm{~d}, J=14.6 \mathrm{~Hz}, 1 \mathrm{H}), 4.76(\mathrm{~d}, J=14.6 \mathrm{~Hz}, 1 \mathrm{H}), 5.09(\mathrm{~d}, J=$ $5.1 \mathrm{~Hz}, 1 \mathrm{H}), 6.81(\mathrm{~m}, 2 \mathrm{H}), 6.90(\mathrm{~m}, 2 \mathrm{H}), 6.97(\mathrm{~m}, 2 \mathrm{H}) .{ }^{13} \mathrm{C} \mathrm{NMR}\left(\mathrm{CDCl}_{3}\right): \delta=9.80,15.2,47.5$, 55.36, 55.38, 59.4, 64.0, 65.0, 73.8, 76.8, 76.9, 77.2, 77.4, 114.0, 114.3, 114.5, 125.8, 126.39, $126.43,128.1,128.4,128.6,128.7,129.6,133.2,141.0,141.3,159.3,159.8$. 


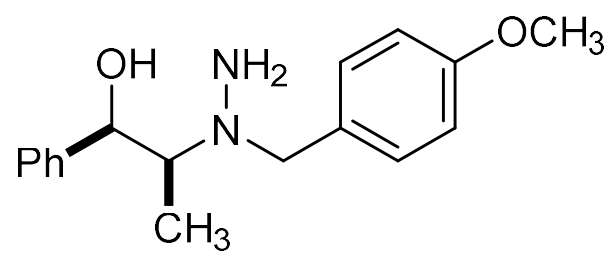

77

(1R,2S)-2-(1-(para-Methoxybenzyl)hydrazinyl)-1-phenyl-1-propanol (77): To a $2000 \mathrm{~mL}$ flame dried, nitrogen purged three neck round bottom flask fitted with a pressure equalizing addition funnel and a water cooled reflux condenser, was added $\mathrm{LiAlH}_{4}(4.60 \mathrm{~g}, 121 \mathrm{mmol})$ followed by THF $(300 \mathrm{~mL})$ to give a dark gray suspension. Heat was applied and THF brought to reflux, at which point $N$-((1R,2S)-1-hydroxy-1-phenylpropan-2-yl)- $N$-(4-methoxybenzyl) nitrous amide $2.2(18.1 \mathrm{~g}, 60.3 \mathrm{mmol})$ dissolved in THF $(150 \mathrm{~mL})$ was poured into the $\mathrm{LiAlH}_{4}-\mathrm{THF}$ mixture dropwise from the addition funnel after which the reaction was stirred under reflux for 3 hours. By the end, the reaction mixture took the color of pea soup, at which point heat was removed and reaction allowed to cool to room temperature. The reaction was quenched with dropwise addition of $1 \mathrm{M} \mathrm{NaOH}(100 \mathrm{~mL})$ from addition funnel. Upon addition of $\mathrm{NaOH}$ heavy precipitate formation was observed. The precipitate was broken into a slurry and allowed to settle, the supernatant solution was decanted to a $1000 \mathrm{~mL}$ round bottom flask and most of the THF was removed under reduced pressure. The concentrated reaction mixture was reconstituted with $250 \mathrm{~mL}$ ethyl acetate and $70 \mathrm{~mL} 1 \mathrm{M} \mathrm{NaOH}$ and the organic layer was separated, and the aqueous layer was back extracted with $100 \mathrm{~mL}$ ethyl acetate. The organic layers were combined, washed with $50 \mathrm{~mL}$ brine, dried with $\mathrm{MgSO}_{4}$, filtered and the solvents removed in vacuo. To give the crude $\beta$-hydroxyhydrazine which went on to the cyclization step. 
<smiles>COc1ccc(CN2NC(=O)OC(c3ccccc3)C2C)cc1</smiles>

73

\section{(5S,6R)-4-(para-Methoxybenzyl)-5-methyl-6-phenyl-1,3,4-oxadiazinone (73):}

To a $1000 \mathrm{~mL}$ round bottom flask containing the crude hydrazine (77) $(17.12 \mathrm{~g}, 59.80 \mathrm{mmol})$, was added dichloromethane $(540 \mathrm{~mL})$ and triethylamine $(25.0 \mathrm{~mL}, 179 \mathrm{mmol})$ sequentially and the resulting solution was cooled in an ice bath. Triphosgene $(5.860 \mathrm{~g}, 19.73 \mathrm{mmol})$ was then added to the cold solution and the reaction was allowed to stir for 16 hours at room temperature after which it was washed with $1 \mathrm{M} \mathrm{HCl}(50 \mathrm{~mL})$ followed by brine wash $(50 \mathrm{~mL})$. The organic layer was dried over $\mathrm{MgSO}_{4}$ solvent removed under reduced pressure. The crude product obtained was purified by flash column chromatography (hexanes: ethyl acetate, 70:30) to give the title compound as a yellow viscous oil in a $53 \%$ yield over two steps. ${ }^{1} \mathrm{H} \mathrm{NMR}\left(\mathrm{CDCl}_{3}\right): \delta=$ $0.91(\mathrm{~d}, J=6.9 \mathrm{~Hz}, 3 \mathrm{H}), 3.25(\mathrm{dq}, J=6.9 \mathrm{~Hz}, 3.0 \mathrm{~Hz}, 1 \mathrm{H}), 3.83(\mathrm{~s}, 3 \mathrm{H}), 4.02(\mathrm{~d}, J=12.4 \mathrm{~Hz}$, $1 \mathrm{H}), 4.15(\mathrm{~d}, J=12.4 \mathrm{~Hz}, 1 \mathrm{H}), 5.8(\mathrm{~d}, J=3.0 \mathrm{~Hz}, 1 \mathrm{H}), 6.40(\mathrm{~s}, 1 \mathrm{H}), 6.87-6.96(\mathrm{~m}, 2 \mathrm{H}), 7.28-$ $7.34(\mathrm{~m}, 5 \mathrm{H}), 7.35-7.42(\mathrm{~m}, 2 \mathrm{H}) .{ }^{13} \mathrm{C} \mathrm{NMR}\left(\mathrm{CDCl}_{3}\right): \delta=11.8,53.9,55.4,62.3,74.7,114.3$, $125.3,127.6,128.0,128.6,130.5,136.5,152.2,159.6$. 

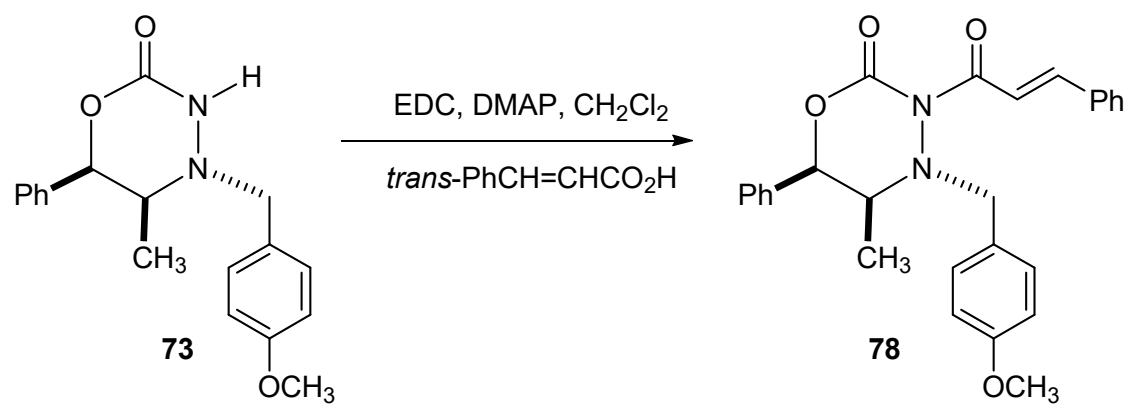

N3-trans-Cinnamoyl-N4-p-methoxybenzyl-4-methyl-6-phenyl-1,3,4-oxadiazinone (78): trans-

Cinnamic acid $(0.807 \mathrm{~g}, 5.45 \mathrm{mmol})$ was added to a flame dried, nitrogen purged $250 \mathrm{~mL}$ round bottom flask and dissolved in anhydrous dichloromethane $(16 \mathrm{~mL})$. This was followed with a sequential addition of the coupling agent 1-ethyl-3-(3-dimethylaminopropyl) carbodiimide (EDC) (1.05 g, $5.45 \mathrm{mmol})$, the 4-dimethylaminopyridine (DMAP) catalyst $(0.110 \mathrm{~g}, 0.90 \mathrm{mmol})$ and the oxadiazinone substrate $(1.42 \mathrm{~g}, 4.54 \mathrm{mmol})$. The reaction was then left stirring for 16 hours at room temperature after which the reaction was diluted with dichloromethane $(80 \mathrm{~mL})$ and washed with $1 \mathrm{M} \mathrm{HCl}(20 \mathrm{~mL}), 1 \mathrm{M} \mathrm{NaOH}(20 \mathrm{~mL})$ (twice) followed by brine $(20 \mathrm{~mL})$ wash. The organic layer thus recovered was dried over magnesium sulfate, gravity filtered, and solvent removed under reduced pressure. The crude product obtained was purified by flash column chromatography (hexane: ethyl acetate, $80: 20)$ to yield $1.14 \mathrm{~g}(80 \%)$ of the title compound as a white fluffy solid: $\mathrm{MP}: 57-61^{\circ} \mathrm{C} .{ }^{1} \mathrm{H}$ NMR $\left(\mathrm{CDCl}_{3}\right): \delta=0.85(\mathrm{~d}, J=7.0 \mathrm{~Hz}, 3 \mathrm{H}) 3.47(\mathrm{dq}, J=$ 4.8, 7.0 Hz, 1H) $3.82(\mathrm{~s}, 3 \mathrm{H}) 4.20(\mathrm{~d}, J=12.5 \mathrm{~Hz}, 1 \mathrm{H}) 4.39(\mathrm{~d}, J=12.5 \mathrm{~Hz}, 1 \mathrm{H}) 6.14(\mathrm{~d}, J=4.6$ Hz, 1H) $6.94(\mathrm{~d}, J=8.6 \mathrm{~Hz}, 2 \mathrm{H}) 7.26(\mathrm{~d}, J=7.8 \mathrm{~Hz}, 2 \mathrm{H}) 7.33(\mathrm{t}, J=7.3,1 \mathrm{H}), 7.39(\mathrm{~d}, J=7.8$, 2H) $7.41-7.43(\mathrm{~m}, 3 \mathrm{H}), 7.47(\mathrm{~d}, J=8.6 \mathrm{~Hz}, 2 \mathrm{H}) 7.52(\mathrm{~d}, J=15.7 \mathrm{~Hz}, 1 \mathrm{H}) 7.59(\mathrm{~m}, 2 \mathrm{H}) 7.78(\mathrm{~d}$, $J=15.7 \mathrm{~Hz}, 1 \mathrm{H}) .{ }^{13} \mathrm{C} \mathrm{NMR}\left(\mathrm{CDCl}_{3}\right): \delta=12.5,52.0,55.3,59.3,78.0,114.4,119.1,124.9,127.0$, $128.2,128.4,128.7,128.8,130.4,130.7,134.9,135.9,145.4,148.2,159.8,166.8 . \mathrm{IR}\left(\mathrm{CHCl}_{3}\right)$ : 
$1760,1727,1615,1247,1216,1136,823,736,701 \mathrm{~cm}^{-1}$. ESI-HRMS calcd for $\mathrm{C}_{27} \mathrm{H}_{26} \mathrm{~N}_{2} \mathrm{NaO}_{4}$ $\left(\mathrm{M}+\mathrm{Na}^{+}\right): 465.1785$. Found: 465.1779. 


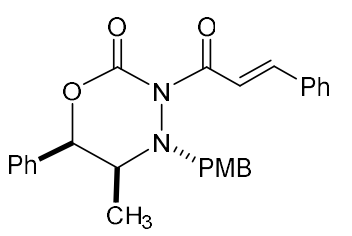

78

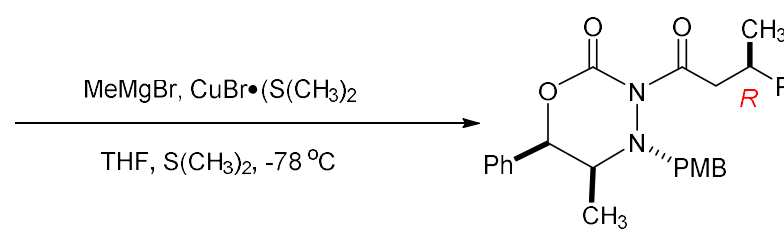

$81 \mathrm{a}$

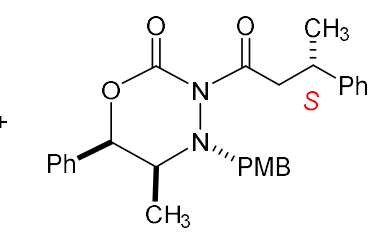

$81 b$

N3-trans-Cinnamoyl-N4-p-methoxybenzyl-4-methyl-6-phenyl-3-(3'-phenylbutanoyl)-1,3,4oxadiazinone (81): To a flame dried, nitrogen purged three-neck $100 \mathrm{~mL}$ round bottomed flask was added copper bromide dimethyl sulfide complex (0.696 g, $3.39 \mathrm{mmol})$, tetrahydrofuran (THF) ( $5 \mathrm{~mL}$ ) by syringe and dimethyl sulfide solvent $(5 \mathrm{~mL})$ by syringe, one after the other. The reaction was then cooled to a temperature of $-78{ }^{\circ} \mathrm{C}$ using dry ice and ethanol. Methyl magnesium bromide $(1.13 \mathrm{~mL}, 3.39 \mathrm{mmol})$ was then carefully added to the solution by syringe and left to stir for 45 minutes at $-78^{\circ} \mathrm{C}$. The $\mathrm{N}_{3}$-cinnamoyloxadiaxinone (x) substrate $(0.500 \mathrm{~g}$, $1.13 \mathrm{mmol})$ was dissolved in THF $(6 \mathrm{~mL})$ and then added dropwise to the reaction vessel via addition funnel. The reaction was left stirring overnight, gradually warming up to room temperature. The reaction was then diluted with ethyl acetate $(80 \mathrm{~mL})$ and washed with $1 \mathrm{M}$ $\mathrm{NaOH}(20 \mathrm{~mL}), 1 \mathrm{M} \mathrm{HCl}(20 \mathrm{~mL})$ and brine solution $(20 \mathrm{~mL})$. The recovered organic layer was dried with magnesium sulfate, filtered under gravity and solvent removed under high vacuum. The crude product obtained was purified by flash column chromatography (hexanes: ethyl acetate, $80: 20)$ to yield $0.321 \mathrm{~g}(60 \%)$ of the titled compound as a yellow viscous oil. ${ }^{1} \mathrm{H}$ NMR $\left(\mathrm{CDCl}_{3}\right): \delta=0.61(\mathrm{~d}, J=7.0 \mathrm{~Hz}, 3 \mathrm{H}), 1.20(\mathrm{~d}, J=6.9 \mathrm{~Hz}, 3 \mathrm{H}), 2.95(\mathrm{dd}, J=7.9,16.7 \mathrm{~Hz}, 1 \mathrm{H})$, 3.22-3.27 (m, 3H), 3.30-3.37 (m, 1H), $3.75(\mathrm{~s}, 3 \mathrm{H}), 3.92(\mathrm{~d}, J=12.5 \mathrm{~Hz}, 1 \mathrm{H}), 4.01(\mathrm{~d}, J=12.5$ $\mathrm{Hz}, 1 \mathrm{H}), 5.93(\mathrm{~d}, J=4.5 \mathrm{~Hz}, 1 \mathrm{H}), 6.82-6.85(\mathrm{~m}, 2 \mathrm{H}), 7.07-7.11(\mathrm{~m}, 3 \mathrm{H}), 7.17-7.20(\mathrm{~m}, 5 \mathrm{H})$, 7.25-7.28 (m, 2H), 7.32-7.34 (m, 2H). ${ }^{13} \mathrm{C} \mathrm{NMR}\left(\mathrm{CDCl}_{3}\right): \delta=12.3,21.9,36.0,45.6,51.4,55.3$, 
$58.7,77.9,114.3,124.8,126.2,127.0,127.1,128.1,128.5,128.7,130.7,135.9,146.2,148.4$, 159.8, 172.6. ESI-HRMS calcd for $\mathrm{C}_{28} \mathrm{H}_{30} \mathrm{~N}_{2} \mathrm{NaO}_{4}\left(\mathrm{M}+\mathrm{Na}^{+}\right)$: 481.2098. Found: 481.2090. 

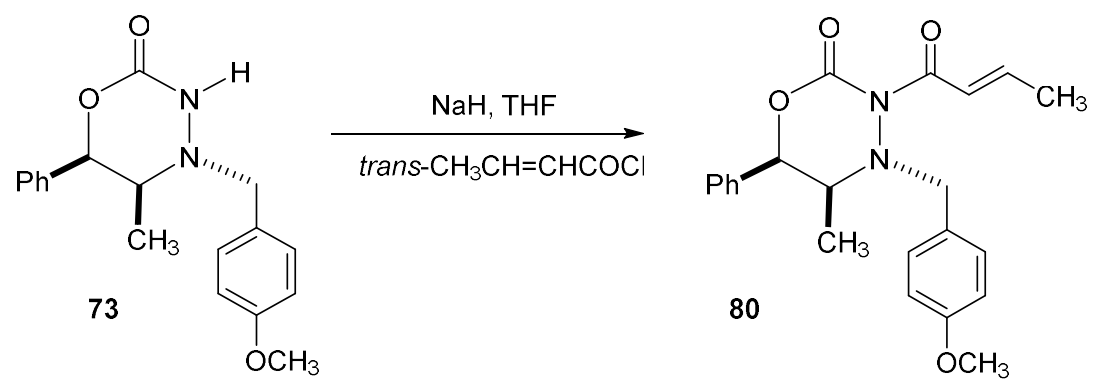

N3-trans-Crotonyl-N4-p-methoxybenzyl-4-methyl-6-phenyl-1,3,4-oxadiazinone (80): To a flame-dried nitrogen-purged $100 \mathrm{~mL}$ round bottom flask was added the oxadiazinone substrate $(0.50 \mathrm{~g}, 1.6 \mathrm{mmol})$ which was dissolved in dimethylformamide (DMF) $(8.00 \mathrm{~mL})$. To the solution was added the sodium hydride base $(0.077 \mathrm{~g}, 3.2 \mathrm{mmol})$. The reaction was allowed to stir for 10 minutes and the crotonyl chloride $(0.17 \mathrm{~mL}, 1.8 \mathrm{mmol})$ was then added. The reaction was left stirring for 18 hours at room temperature, after which it was diluted with dichloromethane $(50 \mathrm{~mL})$ and washed with $1 \mathrm{M} \mathrm{HCl}(20 \mathrm{~mL})$ and brine $(20 \mathrm{~mL})$. The organic layer thus recovered was dried over magnesium sulfate, gravity filtered, and solvent removed under reduced pressure. The titled compound was isolated as a yellow solid in a yield of $0.595 \mathrm{~g}$ (98\%) after purification by flash column chromatography (hexanes: ethyl acetate, 80:20): MP: $54-56{ }^{\circ} \mathrm{C} .{ }^{1} \mathrm{H}$ NMR $\left(\mathrm{CDCl}_{3}\right) . \delta=0.77(\mathrm{~d}, J=6.9 \mathrm{~Hz}, 3 \mathrm{H}), 1.93(\mathrm{dd}, J=1.4,6.9 \mathrm{~Hz}, 3 \mathrm{H}), 3.38$ $(\mathrm{dq}, J=4.5,7.0 \mathrm{~Hz}, 1 \mathrm{H}) 3.83(\mathrm{~s}, 3 \mathrm{H}) 4.13(\mathrm{~d}, J=12.6 \mathrm{~Hz}, 1 \mathrm{H}) 4.31(\mathrm{~d}, J=12.6 \mathrm{~Hz}, 1 \mathrm{H}) 6.07$ $(\mathrm{d}, J=4.5 \mathrm{~Hz}, 1 \mathrm{H}) 6.92(\mathrm{~d}, J=8.5 \mathrm{~Hz}, 2 \mathrm{H}) 7.07(\mathrm{dq}, J=7.5,15.2 \mathrm{~Hz}, 1 \mathrm{H}) 7.20(\mathrm{~d}, J=7.5 \mathrm{~Hz}$, $2 \mathrm{H}) 7.26-7.37(\mathrm{~m}, 4 \mathrm{H}), 7.42(\mathrm{~d}, J=8.5 \mathrm{~Hz}, 2 \mathrm{H}) .{ }^{13} \mathrm{C} \mathrm{NMR}\left(\mathrm{CDCl}_{3}\right): \delta=12.4,18.5,51.5,55.3$, $59.1,77.9,114.3,123.6,124.9,127.0,128.1,128.7,130.7,135.9,145.7,148.2,159.7,166.6$. IR $\left(\mathrm{CHCl}_{3}\right): 1762,1725,1639,1248,790,823,733 \mathrm{~cm}^{-1}$. ESI-HRMS calcd for $\mathrm{C}_{22} \mathrm{H}_{24} \mathrm{~N}_{2} \mathrm{NaO}_{4}(\mathrm{M}+$ $\mathrm{Na}^{+}$): 403.1628. Found: 403.1622 . 


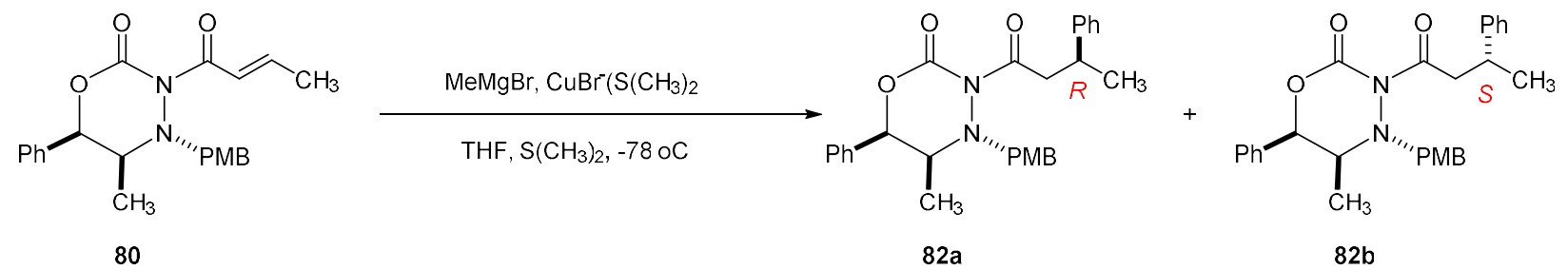

N3-trans-Crotonyl-N4-p-methoxybenzyl-4-methyl-6-phenyl-1,3,4-oxadiazinone (82): To a

flame dried, nitrogen purged three-neck $100 \mathrm{~mL}$ round bottomed flask was added copper bromide dimethyl sulfide complex $(0.580 \mathrm{~g}, 2.82 \mathrm{mmol})$, tetrahydrofuran (THF) $(5 \mathrm{~mL}$, by syringe) and dimethyl sulfide solvent ( $5 \mathrm{~mL}$, by syringe), one after the other. The reaction was then cooled to a temperature of $-78^{\circ} \mathrm{C}$ using dry ice and ethanol. Methyl magnesium bromide $(0.940 \mathrm{~mL}, 2.82 \mathrm{mmol})$ was then carefully added to the solution by syringe and left to stir for 45 minutes at $-78^{\circ} \mathrm{C}$. The $\mathrm{N}_{3}$-crotonyloxadiaxinone (80) substrate $(0.358 \mathrm{~g}, 0.940 \mathrm{mmol})$ was dissolved in THF (6 mL) and then added dropwisely to the reaction vessel via addition funnel. The reaction was left stirring for 17 hours while it gradually warmed up to room temperature. The reaction was then diluted with ethyl acetate $(80 \mathrm{~mL})$ and washed with $1 \mathrm{M} \mathrm{NaOH}(20 \mathrm{~mL}), 1$ $\mathrm{M} \mathrm{HCl}(20 \mathrm{~mL})$ and brine solution $(20 \mathrm{~mL})$. The recovered organic layer was dried with magnesium sulfate, filtered under gravity and solvent removed under high vacuum. The crude product obtained was purified by flash column chromatography (Hexane: ethyl acetate, 70:30) to yield $0.224 \mathrm{~g}(52 \%)$ of the titled compound as a yellow viscous oil: (only the major isomer is reported $){ }^{1} \mathrm{H} \mathrm{NMR}\left(\mathrm{CDCl}_{3}\right): \delta=0.58(\mathrm{~d}, J=7.0 \mathrm{~Hz}, 3 \mathrm{H}), 1.33(\mathrm{~d}, J=7.0 \mathrm{~Hz}, 3 \mathrm{H}), 3.17(\mathrm{dd}, J=$ 7.3, $16.7 \mathrm{~Hz}, 1 \mathrm{H}) 3.29-3.33(\mathrm{~m}, 2 \mathrm{H}), 3.35-3.38(\mathrm{sxt}, J=6.9 \mathrm{~Hz}, 1 \mathrm{H}), 3.85(\mathrm{~s}, 3 \mathrm{H}), 4.07(\mathrm{~d}, J=$ $12.4 \mathrm{~Hz}, 1 \mathrm{H}), 4.19(\mathrm{~d}, J=12.4 \mathrm{~Hz}, 1 \mathrm{H}), 6.05(\mathrm{~d}, J=4.6 \mathrm{~Hz}, 1 \mathrm{H}) 6.93-6.96(\mathrm{~m}, 2 \mathrm{H}), 7.17-7.21$ $(\mathrm{m}, 3 \mathrm{H}), 7.26-7.32(\mathrm{~m}, 4 \mathrm{H})$ 7.35-7.38 (m, $2 \mathrm{H}), 7.42-7.47(\mathrm{~m}, 3 \mathrm{H}) .{ }^{13} \mathrm{C} \mathrm{NMR}\left(\mathrm{CDCl}_{3}\right) \delta=12.2$ $22.1,36.2,45.6,51.2,55.3,58.6,78.0,114.3,124.8,126.3,127.0,128.1,128.5,128.7,128.8$, 
130.6, 135.9, 146.1, 148.7, 159.7, 172.5. IR $\left(\mathrm{CHCl}_{3}\right): 1775,1726,1213,1136,850,740,700 \mathrm{~cm}^{-}$ 1. ESI-HRMS calcd for $\mathrm{C}_{28} \mathrm{H}_{30} \mathrm{~N}_{2} \mathrm{NaO}_{4}\left(\mathrm{M}+\mathrm{Na}^{+}\right)$: 481.2098. Found: 481.2100. 

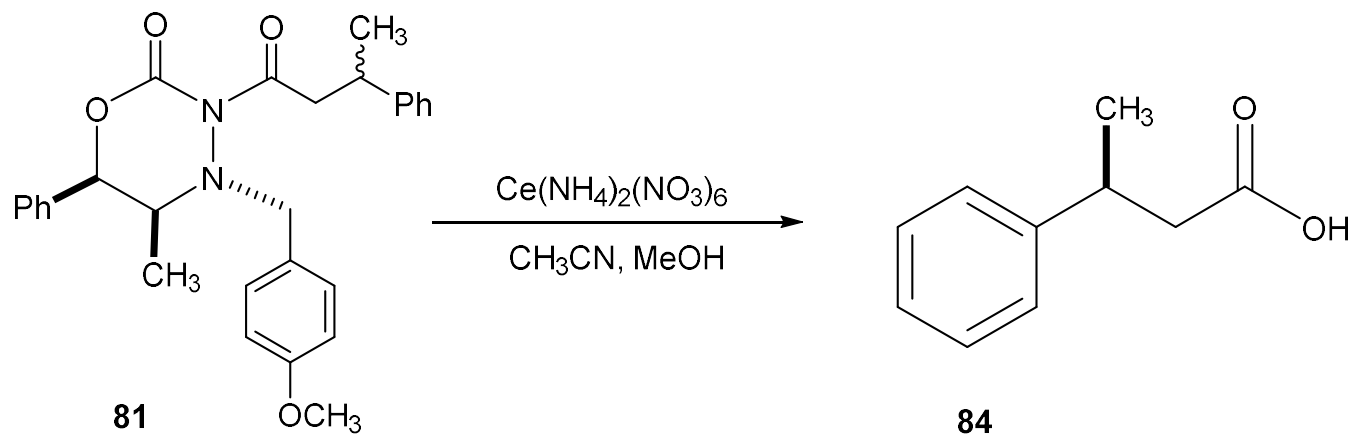

(S)-(+)-3-phenylbutyric acid (84): The $\mathrm{N}_{3}-(3-$ methylcinnamoyl)-N 4 -para-methoxybenzyl oxadiazinone substrate $(1.26 \mathrm{~g}, 2.74 \mathrm{mmol})$ was added together with acetonitrile $(50 \mathrm{~mL})$ into a $250 \mathrm{~mL}$ round bottom flask and homogenized by stirring. To the homogenized mixture was added Ceric ammonium nitrate $\left(\mathrm{Ce}\left(\mathrm{NH}_{4}\right)_{2} \mathrm{NO}_{3}\right)(7.53 \mathrm{~g}, 13.7 \mathrm{mmol})$ pre-dissolved in deionized water $(50 \mathrm{~mL})$. The reaction was left to stir for $3 \mathrm{hrs}$. The mixture was thereafter put on rotary evaporator to get rid of the solvents. The concentrated solution was then extracted with diethyl ether $(50 \mathrm{~mL})$ and brine solution $(30 \mathrm{~mL})$. The recovered organic layer was treated with $1 \mathrm{M}$ $\mathrm{NaOH}(30 \mathrm{~mL})$ and dried with $\mathrm{MgSO}_{4}$. The aqueous layer was further treated with $3 \mathrm{M} \mathrm{HCl}(30$ $\mathrm{mL})$ and extracted with diethyl ether $(50 \mathrm{~mL})$. The second organic product was washed with brine and also dried with $\mathrm{MgSO}_{4}$. Both organic products were filtered under gravity and solvent removed under high vacuum. The second organic product contained the target molecule and was therefore taken through further purification by flash column chromatography (Hexanes-ethyl acetate, 80:20). This yielded the title compound $(0.10 \mathrm{~g}, 22 \%)$ as a colorless oil: $[\alpha]^{23} \mathrm{D}+22 .{ }^{1} \mathrm{H}$ $\operatorname{NMR}\left(\mathrm{CDCl}_{3}\right): \delta=1.33(\mathrm{~d}, J=7.0 \mathrm{~Hz}, 3 \mathrm{H}), 2.58(\mathrm{dd}, J=8.2,15.5 \mathrm{~Hz}, 1 \mathrm{H}), 2.68(\mathrm{dd}, J=6.8$ $\mathrm{Hz}, 1 \mathrm{H}), 3.28$ (sxt, $J=7.0 \mathrm{~Hz}, 1 \mathrm{H}), 7.19-23(\mathrm{~m}, 3 \mathrm{H}), 7.29-7.32(\mathrm{~m}, 2 \mathrm{H}) .{ }^{13} \mathrm{C} \mathrm{NMR}\left(\mathrm{CDCl}_{3}\right): \delta=$ 21.9, 36.2, 42.6, 126.5, 126.7, 128.6, 145.5, 178.5. IR (neat): 2970, 1706, 1296, 763, $700 \mathrm{~cm}^{-1}$. ESI HRMS for $\mathrm{C}_{11} \mathrm{H}_{14} \mathrm{~N}_{2} \mathrm{NaO}_{2}{ }^{+}$: calcd $\left(\mathrm{M}+\mathrm{Na}^{+}\right)$187.0730, found 187.0730. 


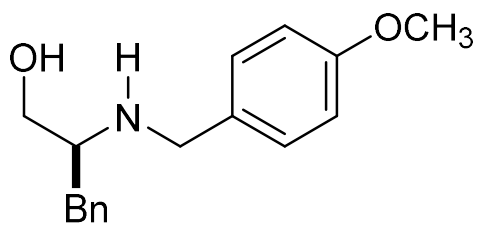

86

N-para-Methoxybenzyl-L-phenylalaninol (86): To a $1000 \mathrm{~mL}$ round bottom flask containing L-phenylalaninol (15.678 g, $103.7 \mathrm{mmol})$ was added para-anisaldehyde (14.0 mL, $114 \mathrm{mmol})$ and $100 \%$ methanol $(150 \mathrm{~mL})$ to make a solution. To the solution was added two scoops of $\mathrm{MgSO}_{4}$ and allowed to stir overnight. At which point $\mathrm{NaBH}_{4}(5.90 \mathrm{~g}, 155.5 \mathrm{mmol})$ was added to the reaction and stirred for another for 2 hours, after which $50 \mathrm{~mL} 1 \mathrm{M} \mathrm{NaOH}$ was added to the reaction mixture and stirred for 1 hour. Then most of the ethanol was removed in vacuo and the resulting slurry was reconstituted with $200 \mathrm{~mL}$ ethyl acetate and the organic layer was collected and washed with $50 \mathrm{~mL}$ DI water, $50 \mathrm{~mL}$ brine, dried over $\mathrm{MgSO}_{4}$, filtered and solvents removed in vacuo to give a crude solid. The crude product was than recrystallized to give the title compound as white crystals in $90 \%$ yield. MP: $88-90{ }^{\circ} \mathrm{C} .{ }^{1} \mathrm{H} \mathrm{NMR}\left(\mathrm{CDCl}_{3}\right): \delta=2.78(\mathrm{dd}, J$ $=6.8,13.7 \mathrm{~Hz}, 1 \mathrm{H}), 2.84(\mathrm{dd}, J=7.0,13.7 \mathrm{~Hz}, 1 \mathrm{H}), 2.96-3.00(\mathrm{~m}, 1 \mathrm{H}), 3.37(\mathrm{dd}, J=5.4,10.8$ $\mathrm{Hz}, 1 \mathrm{H}), 3.66(\mathrm{dd}, J=3.9,10.8 \mathrm{~Hz}, 1 \mathrm{H}), 3.74(\mathrm{~s}, 2 \mathrm{H}), 3.82(\mathrm{~s}, 3 \mathrm{H}), 6.86(\mathrm{~d}, J=8.6 \mathrm{~Hz}, 2 \mathrm{H}), 7.15$ $(\mathrm{d}, J=8.6 \mathrm{~Hz}, 2 \mathrm{H}), 7.19(\mathrm{~d}, J=7.5 \mathrm{~Hz}, 2 \mathrm{H}), 7.24-7.28(\mathrm{~m}, 1 \mathrm{H}), 7.30-7.34(\mathrm{~m}, 2 \mathrm{H}) .{ }^{13} \mathrm{C} \mathrm{NMR}$ $\left(\mathrm{CDCl}_{3}\right)$ : (one of the aromatic carbons was not observed potentially due to coincidental overlap) $\delta=38.1,50.6,55.3,59.5,62.7,113.9,126.4,128.6,129.3,132.2,138.7,158.8 . \mathrm{IR}\left(\mathrm{CHCl}_{3}\right):$ $3288,2900,1608,1248,1177,857,746,699 \mathrm{~cm}^{-1}$. ESI-HRMS calcd for $\mathrm{C}_{17} \mathrm{H}_{22} \mathrm{NO}_{2}\left(\mathrm{M}+\mathrm{H}^{+}\right)$: 272.1645. Found: 272.1637. 


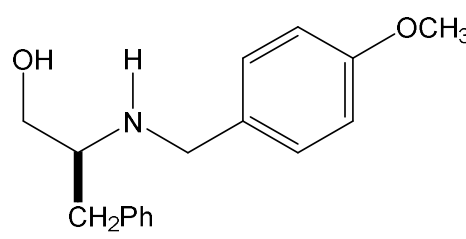

86

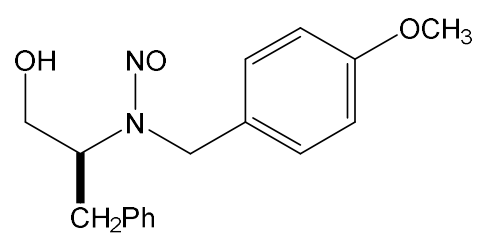

87

(S)-N-(1-Hydroxy-3-phenyl-2-propanyl)- $N$-(4-methoxybenzyl)nitrous amide (87): To a 1000 $\mathrm{mL}$ round bottom flask containing $N$-p-methoxybenzyl-L-phenylalaninol (23.1 g, $85.1 \mathrm{mmol})$ was added THF $(100 \mathrm{~mL})$ and $2 \mathrm{M} \mathrm{HCl}(64.0 \mathrm{~mL}, 128 \mathrm{mmol})$ to make a homogeneous solution. To the solution was added $\mathrm{NaNO}_{2}(5.87 \mathrm{~g}, 85.1 \mathrm{mmol})$ in one portion which reacted exothermically. The reaction was stirred overnight. At which point the reaction was extracted with $200 \mathrm{~mL}$ ethyl acetate and the organic layer was washed with aqueous hydrochloric acid (1M $\mathrm{HCl}, 25 \mathrm{~mL}$ ), brine (25 mL), dried over $\mathrm{MgSO}_{4}$, filtered and solvents removed in vacuo. The crude material was then recrystallized to give the title compound as a yellow solid in $88 \%$ yield. MP: $79-81{ }^{\circ} \mathrm{C} .{ }^{1} \mathrm{H}$ NMR $\left(\mathrm{CDCl}_{3}\right): \delta=3.13(\mathrm{dd}, J=8.2,13.8 \mathrm{~Hz}, 1 \mathrm{H}), 3.19(\mathrm{dd}, J=6.913 .8 \mathrm{~Hz}$ $1 \mathrm{H}), 3.80(\mathrm{~s}, 3 \mathrm{H}), 3.96(\mathrm{~d}, J=5.5 \mathrm{~Hz}, 2 \mathrm{H}), 4.31-4.36(\mathrm{~m}, 1 \mathrm{H}), 4.41(\mathrm{~d}, J=14.6 \mathrm{~Hz}, 1 \mathrm{H}), 4.82(\mathrm{~d}$, 14.6 Hz, 1H), $6.80(\mathrm{~d}, J=8.6 \mathrm{~Hz}, 2 \mathrm{H}), 6.95(\mathrm{~d}, J=8.6 \mathrm{~Hz}, 2 \mathrm{H}), 7.10-7.11(\mathrm{~m}, 2 \mathrm{H}), 7.24-7.30$ $(\mathrm{m}, 3 \mathrm{H}) .{ }^{13} \mathrm{C} \mathrm{NMR}\left(\mathrm{CDCl}_{3}\right): \delta=37.6,47.9,55.3,64.2,65.9,114.2,126.1,126.9,128.7,129.1$, 129.8, 137.1, 159.3. IR $\left(\mathrm{CHCl}_{3}\right): 3354,1612,1448,1249,1177,1138,837,732,701 \mathrm{~cm}^{-1}$. ESIHRMS calcd for $\mathrm{C}_{17} \mathrm{H}_{20} \mathrm{~N}_{2} \mathrm{NaO}_{3}\left(\mathrm{M}+\mathrm{Na}^{+}\right)$: 323.1366. Found: 323.1357 . 


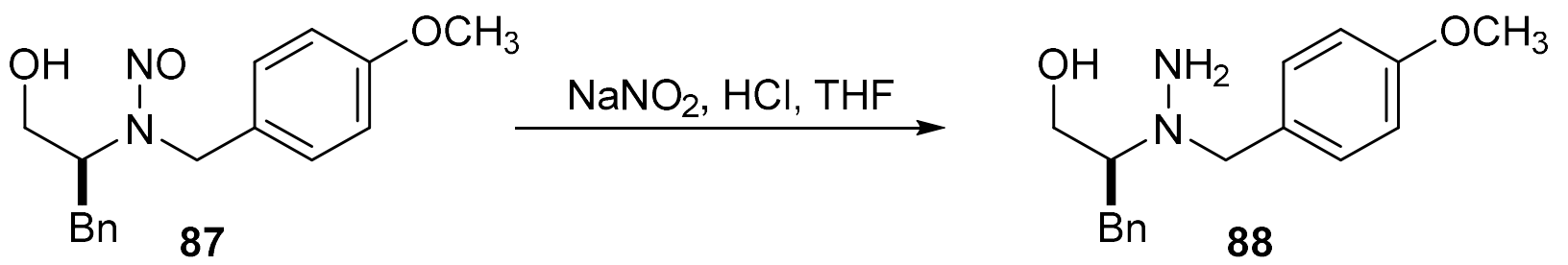

(S)-2-(1-(4-Methoxybenzyl)hydrazinyl)-3-phenyl-1-propanol (88): To a $2000 \mathrm{~mL}$ flame dried, nitrogen purged, three neck round bottom flask fitted with a pressure equalizing addition funnel and a water cooled reflux condenser, was added $\mathrm{LiAlH}_{4}(5.689 \mathrm{~g}, 149.9 \mathrm{mmol})$, and then was added THF (500 mL) to give a dark gray suspension. Heat was applied and THF brought to reflux, at which point $N$-nitrosamine (87) (22.5 g, $74.9 \mathrm{mmol})$ dissolved in THF (100 mL) was poured into the $\mathrm{LiAlH}_{4}$-THF mixture dropwise from the addition funnel. The reaction was stirred under reflux for 3 hours. By the end, the reaction mixture took the color of pea soup, at which point heat was removed and reaction allowed to cool to room temperature. The reaction was quenched with dropwise addition of $1 \mathrm{M} \mathrm{NaOH}(100 \mathrm{~mL})$ from addition funnel. Upon addition of $\mathrm{NaOH}$ heavy precipitate formation occurred. The precipitate was broken into a slurry and allowed to settle, the supernatant solution was then decanted to a $1,000 \mathrm{~mL}$ round bottom flask and pumped to remove most of the THF. The concentrated reaction mixture was reconstituted with $250 \mathrm{~mL}$ ethyl acetate and $70 \mathrm{~mL} 1 \mathrm{M} \mathrm{NaOH}$ and the organic layer was separated, and the aqueous layer was back extracted with $100 \mathrm{~mL}$ ethyl acetate. The organic layers were combined, washed with $50 \mathrm{~mL}$ brine, dried with $\mathrm{MgSO}_{4}$, filtered and the solvents removed in vacuo to give the crude $\beta$-Hydroxy hydrazine which went on to the cyclization step. 


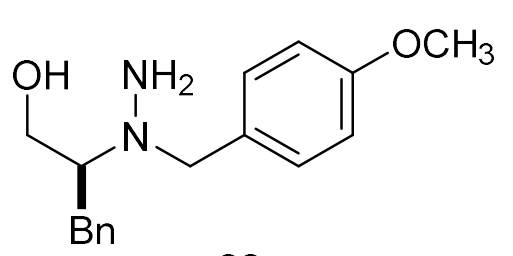

88
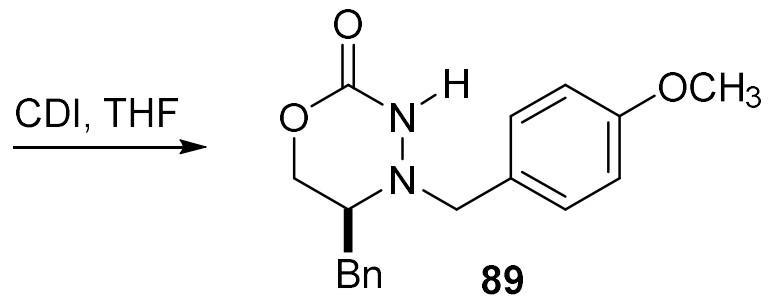

(S)-5-Benzyl-4-(para-methoxybenzyl)-1,3,4-oxadiazinone (89): Tetrahydrofuran (THF) (20 $\mathrm{mL})$ was added to the beta-hydoxyl hydrazine $(21.124 \mathrm{~g}, 73.8 \mathrm{mmol})$ substrate in a flame dried nitrogen purged $250 \mathrm{~mL}$ round bottomed flask and left to homogenize at room temperature. Carbonyldiimidazole (CDI) (12.0 g, $73.8 \mathrm{mmol})$ was then added to the solution and left stirring for 18 hours at room temperature. Thereafter, the solution was subjected to rotary evaporation to remove the THF solvent and the resulting viscous oil was diluted with ethyl acetate $(80 \mathrm{~mL})$ and washed with $1 \mathrm{M} \mathrm{HCl}(15 \mathrm{~mL})$ and brine solution $(15 \mathrm{~mL})$. The recovered organic layer was dried over $\mathrm{MgSO}_{4}$, filtered under gravity and solvents-removed under reduced pressure. The crude product was purified by flash column chromatography (hexanes: Ethylacetate, 60:40) to yield $8.05 \mathrm{~g}(35 \%)$ of the title compound as a yellow solid. MP: $111-112{ }^{\circ} \mathrm{C} .{ }^{1} \mathrm{H} \mathrm{NMR}\left(\mathrm{CDCl}_{3}\right)$ : $\delta=2.89(\mathrm{dd}, J=8.0,13.9 \mathrm{~Hz}, 1 \mathrm{H}), 2.99(\mathrm{dd}, J=7.4,13.9 \mathrm{~Hz}, 1 \mathrm{H}), 3.17-3.21(\mathrm{~m}, 1 \mathrm{H}), 3.19(\mathrm{~s}$, $3 \mathrm{H}), 3.83(\mathrm{~d}, J=12.8 \mathrm{~Hz}, 1 \mathrm{H}), 4.01(\mathrm{~d}, J=12.8 \mathrm{~Hz}, 1 \mathrm{H}), 4.17(\mathrm{dd}, J=2.1,11.5 \mathrm{~Hz}, 1 \mathrm{H}), 4.60($ $\mathrm{dd}, J=3.4,11.5 \mathrm{~Hz}, 1 \mathrm{H}), 6.82(\mathrm{bs}, 1 \mathrm{H}), 6.84(\mathrm{~d}, J=8.7 \mathrm{~Hz}, 2 \mathrm{H}), 2 \mathrm{H}), 7.11(\mathrm{~d}, J=8.7 \mathrm{~Hz}, 2 \mathrm{H})$, $7.17(\mathrm{~d}, J=7.6 \mathrm{~Hz}, 2 \mathrm{H}), 7.25-7.33(\mathrm{~m}, 3 \mathrm{H}) .{ }^{13} \mathrm{C} \mathrm{NMR}\left(\mathrm{CDCl}_{3}\right): \delta=36.2,55.2,55.3,61.7,64.1$, 114.1, 126.7, 127.4, 128.6, 129.3, 130.2, 137.5, 151.9, 159.4. IR $\left(\mathrm{CHCl}_{3}\right): 3235,1718,1242$, 833, 772, $699 \mathrm{~cm}^{-1}$. ESI-HRMS calcd for $\mathrm{C}_{18} \mathrm{H}_{20} \mathrm{~N}_{2} \mathrm{NaO}_{3}\left(\mathrm{M}+\mathrm{Na}^{+}\right)$: 335.1366. Found: 335.1358 . 

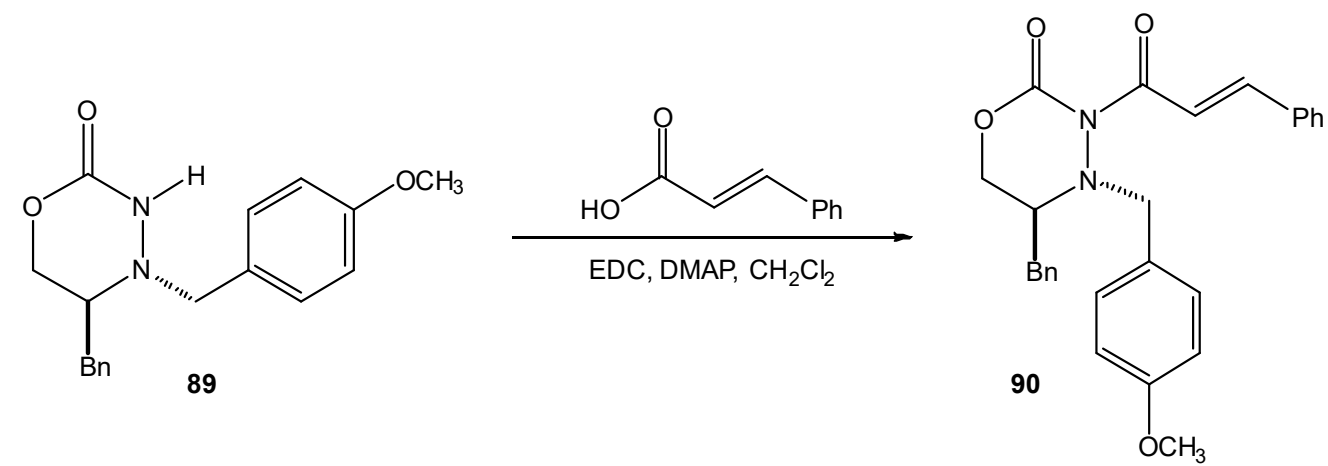

(S)-5-Benzyl-3-trans-crotonyl-4-(para-methoxybenzyl)-1,3,4-oxadiazinone (90): The oxadiazinone substrate $(4.203 \mathrm{~g}, 13.46 \mathrm{mmol})$ was added to a flame dried, nitrogen purged 250 $\mathrm{mL}$ round bottom flask and dissolved in anhydrous dichloromethane $(30 \mathrm{~mL})$. To the solution was added trans-cinnamic acid (2.390 g, $16.20 \mathrm{mmol}), 1$-ethyl-3-(3-dimethylaminopropyl) carbodiimide (EDC) (3.110 g, $16.20 \mathrm{mmol}$ ), and 4-dimethylaminopyridine (DMAP) catalyst $(0.330 \mathrm{~g}, 2.700 \mathrm{mmol})$ sequentially. The reaction was allowed to stir for 18 hours at room temperature, after which it was diluted with dichloromethane $(80 \mathrm{~mL})$ and washed with $1 \mathrm{M} \mathrm{HCl}$ $(20 \mathrm{~mL}), 1 \mathrm{M} \mathrm{NaOH}(20 \mathrm{~mL})$ followed by brine $(20 \mathrm{~mL})$ wash. The organic layer thus recovered was dried over magnesium sulfate, gravity filtered, and solvent removed under reduced pressure. The crude product obtained was purified by flash column chromatography (hexane: ethyl acetate, $65: 35)$ to yield $4.221 \mathrm{~g}(71 \%)$ of the title compound as a yellow viscous oil. ${ }^{1} \mathrm{H}$ NMR: $\delta=2.77$ (dd, $J=6.0,13.9 \mathrm{~Hz}, 1 \mathrm{H}), 2.86$ (dd, $J=8.3,13.9 \mathrm{~Hz}, 1 \mathrm{H}), 3.65$ (bs, 1H), $3.71(\mathrm{~s}, 3 \mathrm{H}), 3.87$ (d, $J$ $=12.5 \mathrm{~Hz}, 1 \mathrm{H}), 4.11(\mathrm{~d}, J=12.5 \mathrm{~Hz}, 1 \mathrm{H}), 4.16(\mathrm{bs}, 1 \mathrm{H}), 4.68(\mathrm{dd}, J=6.2,11.45 \mathrm{~Hz}, 1 \mathrm{H}), 6.76$ $(\mathrm{d}, J=8.2 \mathrm{~Hz}, 2 \mathrm{H}), 7.12(\mathrm{~m}, 5 \mathrm{H}), 7.27-7.32(\mathrm{~m}, 4 \mathrm{H}), 7.41$ (bs, $5 \mathrm{H}), 7.62(\mathrm{~d}, J=14.8,1 \mathrm{H}) .{ }^{13} \mathrm{C}$ NMR $\left(\mathrm{CDCl}_{3}\right)$ : (one of the aromatic carbons was not observed potentially due to line broadening) $\delta=37.7,55.2,58.2,61.8,68.3,114.1,117.7,126.7,126.9,128.4,128.7,129.2$, 
130.3, 131.1, 134.8, 136.7, 144.9, 150.3, 159.6, 166.5. IR $\left(\mathrm{CHCl}_{3}\right): 1769,1680,1615,831,756$, $701 \mathrm{~cm}^{-1}$. ESI-HRMS calcd for $\mathrm{C}_{27} \mathrm{H}_{26} \mathrm{~N}_{2} \mathrm{NaO}_{4}\left(\mathrm{M}+\mathrm{Na}^{+}\right)$: 465.1785. Found: 465.1778. 


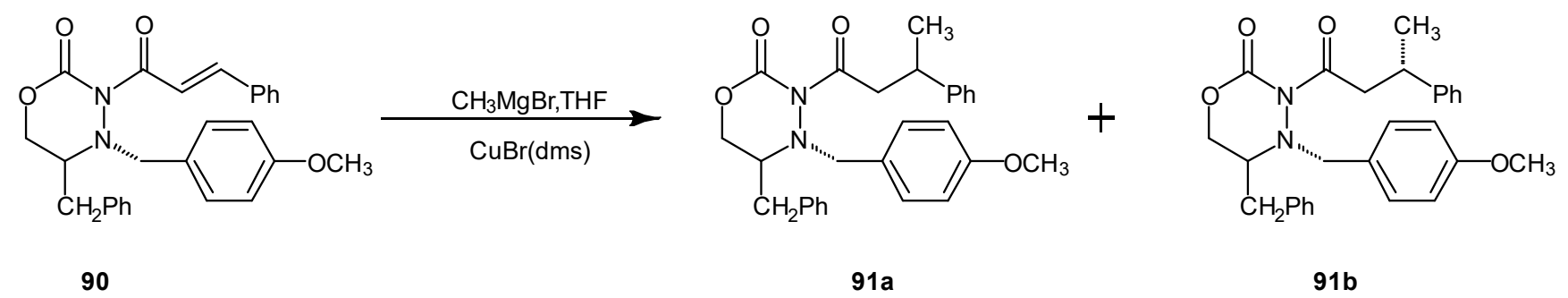

N3-(3-methylcinnamoyl)-N4-para-methoxybenzyl oxadiazinone (91): To a $1000 \mathrm{~mL}$ flamedried, nitrogen purged three-neck round bottomed flask was added copper bromide dimethyl sulfide complex (5.884 g, $28.62 \mathrm{mmol}$ ), tetrahydrofuran (THF) (27 mL, by syringe) and dimethyl sulfide solvent ( $27 \mathrm{~mL}$ by syringe), one after the other. The reaction was then cooled to a temperature of $-78{ }^{\circ} \mathrm{C}$. in a dry ice/ethanol bath. Methyl magnesium bromide $(9.540 \mathrm{~mL}, 28.62$ mmol) was then carefully added to the solution by syringe and left to stir for 45 minutes at -78 ${ }^{\circ} \mathrm{C}$. The acylated heterocycle $(4.221 \mathrm{~g}, 9.540 \mathrm{mmol})$ was dissolved in THF $(30 \mathrm{~mL})$ and then added by dropwise addition to the reaction vessel through an addition funnel. The reaction was left stirring for 15 hours while it gradually warmed up to room temperature. The reaction was then diluted with ethyl acetate $(80 \mathrm{~mL})$ and washed with $1 \mathrm{M} \mathrm{NaOH}(20 \mathrm{~mL}), 1 \mathrm{M} \mathrm{HCl}(20 \mathrm{~mL})$ and brine solution $(20 \mathrm{~mL})$. The recovered organic layer was dried with magnesium sulfate, filtered under gravity and solvent removed under high vacuum. The crude product obtained was purified by flash column chromatography (Hexane: ethyl acetate, $75: 25)$ to yield $0.4291 \mathrm{~g}(9.8 \%)$ of the titled compound as a colorless oil: Significant peak broadening was observed in the ${ }^{1} \mathrm{H}$ NMR analysis of this compound, hence, no further analysis was conducted on it. 


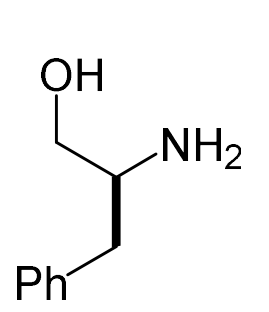

85

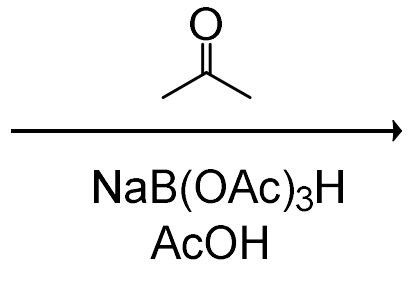

$\mathrm{Ph}^{\prime}$

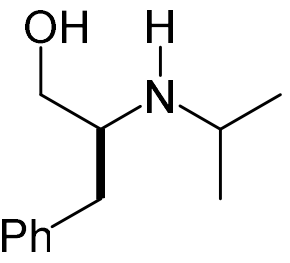

$94 c$

$N$-Isopropyl-L-phenylalaninol (94c): A 1,000 mL round bottom flask was flame dried and nitrogen purged. L-Phenyl alaninol $(15.1 \mathrm{~g}, 99.9 \mathrm{mmol})$ was added to the flask and dissolved in 1,2-dichloroethane $(350 \mathrm{~mL})$. To the solution was added reagent grade acetone $(7.34 \mathrm{~mL}, 99.9$ mmol), Sodium acetoxy borohydride $\left(\mathrm{NaB}(\mathrm{OAc}){ }_{3} \mathrm{H}\right)(29.67 \mathrm{~g}, 140 \mathrm{mmol})$ and acetic acid (6 $\mathrm{mL}$ ), sequentially and stirred for about 22 hours at room temperature. The product was extracted with $6 \mathrm{M} \mathrm{NaOH}(10 \mathrm{~mL})$ and washed with brine. The organic product was dried over $\mathrm{MgSO}_{4}$, filtered under gravity and solvents-removed under reduced pressure to yield $8.43 \mathrm{~g}(44 \%)$ of the target compound as a yellow oil. MP: $52-53{ }^{\circ} \mathrm{C} .{ }^{1} \mathrm{H} \mathrm{NMR}\left(\mathrm{CDCl}_{3}\right): \delta=0.96(\mathrm{~d}, J=6.2 \mathrm{~Hz}, 3 \mathrm{H})$, $1.02(\mathrm{~d}, J=6.2 \mathrm{~Hz}, 3 \mathrm{H}), 2.69(\mathrm{dd}, J=7.2,13.6 \mathrm{~Hz}, 1 \mathrm{H}), 2.75(\mathrm{dd}, J=6.5,13.5 \mathrm{~Hz}, 1 \mathrm{H}) 2.85$ (sept, $J=6.2 \mathrm{~Hz}, 1 \mathrm{H}), 2.94-2.99(\mathrm{~m}, 1 \mathrm{H}), 3.22(\mathrm{dd}, J=5.9,10.4 \mathrm{~Hz}, 1 \mathrm{H}), 3.54(\mathrm{dd}, J=4.1,10.4$ $\mathrm{Hz}, 1 \mathrm{H}), 7.15-7.17(\mathrm{~m}, 2 \mathrm{H}), 7.20-7.23(\mathrm{~m}, 1 \mathrm{H}), 7.28-7.31(\mathrm{~m}, 2 \mathrm{H}) .{ }^{13} \mathrm{C} \mathrm{NMR}\left(\mathrm{CDCl}_{3}\right): \delta=23.4$, 38.5, 46.0, 57.3, 63.0, 126.4, 128.5, 129.2, 138.5. IR (neat): 2964, 1479, $1039 \mathrm{~cm}^{-1}$. ESI-HRMS calcd for $\mathrm{C}_{2}{ }_{2} \mathrm{H}_{21} \mathrm{NO}\left(\mathrm{M}+\mathrm{H}^{+}\right)$: 194.1539. Found: 194.1540 . 


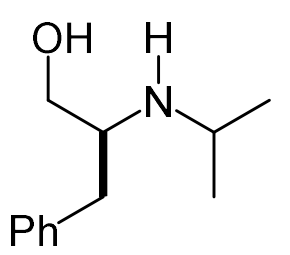

$94 c$

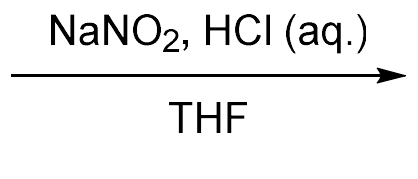

$\mathrm{Ph}^{2}$

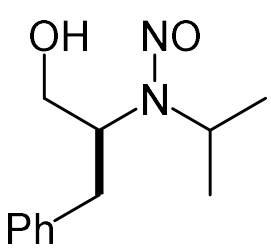

94d

(S)-2-( $N$-Isopropyl- $N$-nitroso-amino)-3-phenyl-1-propanol (94d): To the $N$-isopropyl-Lphenylalaninol $(8.43 \mathrm{~g}, 43.6 \mathrm{mmol})$ starting material in a $1,000 \mathrm{~mL}$ round bottomed flask was added sodium nitrite $\left(\mathrm{NaNO}_{2}\right)(4.00 \mathrm{~g}, 58.0 \mathrm{mmol}), 3 \mathrm{M} \mathrm{HCl}(22 \mathrm{~mL})$ and tetrahydrofuran (THF) $(50 \mathrm{~mL})$ and stirred for 18 hours at room temperature. The reaction was diluted with ethyl acetate $(150 \mathrm{~mL})$ and washed with brine. The organic product was dried over $\mathrm{MgSO}_{4}$, filtered under gravity and solvents-removed under reduced pressure to yield $9.15 \mathrm{~g} \mathrm{(94 \% )}$ of the target Nisopropyl-N4-nitroso-L-phenylalaninol. Only the major isomer is described: ${ }^{1} \mathrm{H} \mathrm{NMR}\left(\mathrm{CDCl}_{3}\right): \delta$ $=0.77(d, J=6.8 \mathrm{~Hz}, 3 \mathrm{H}), 1.12(\mathrm{~d}, J=6.8 \mathrm{~Hz}, 3 \mathrm{H}), 3.22(\mathrm{dd}, J=8.0,13.7 \mathrm{~Hz}, 1 \mathrm{H}), 3.33(\mathrm{dd}, J=$ 7.1, $13.7 \mathrm{~Hz}, 1 \mathrm{H}), 3.78(\mathrm{dd}, J=3.9,11.8 \mathrm{~Hz}, 1 \mathrm{H}), 3.90(\mathrm{dd}, J=6.7,11.8 \mathrm{~Hz}, 1 \mathrm{H}) 4.14-4.25(\mathrm{~m}$, 1H), 4.37 (bs, 1H), 5.05 (sept, $J=6.8 \mathrm{~Hz}, 1 \mathrm{H}), 7.17-7.27$ (m, 3H), 7.30-7.34 (m, 2H). IR $\left(\mathrm{CHCl}_{3}\right): 3411,3027,1601,1454,1172,744,701 \mathrm{~cm}^{-1}$. ESI-HRMS calcd for $\mathrm{C}_{12} \mathrm{H}_{18} \mathrm{~N}_{2} \mathrm{O}_{2}$ : 222.1368. Found: 222.1371. 


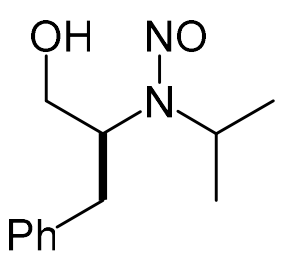

94d

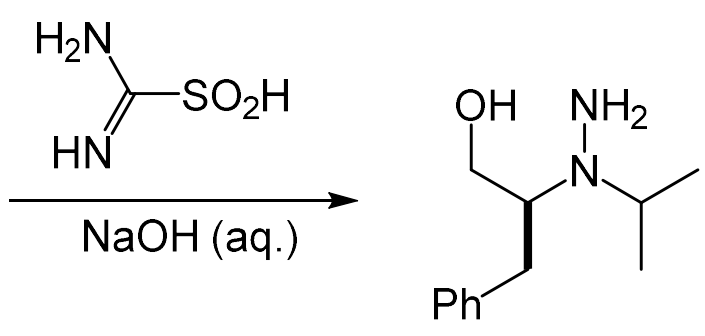

95

(S)-2-(N-Amino- $N$-Isopropyl)amino-3-phenyl-1-propanol (95): To the N-isopropyl-N-nitrosoL-phenylalaninol $(9.150 \mathrm{~g}, 41.16 \mathrm{mmol})$ starting material in a $1,000 \mathrm{~mL}$ round bottomed flask was added methanol $(83 \mathrm{~mL})$ and heated under reflux until temperature rises up to $50^{\circ} \mathrm{C}$. The reaction was heated at $50^{\circ} \mathrm{C}$ for five minutes, aqueous $\mathrm{NaOH}(1 \mathrm{M}, 412 \mathrm{~mL}, 412 \mathrm{mmol})$ was then added. This was followed with the addition of formamidine sulfinic acid (22.25 g, $205.8 \mathrm{mmol})$ Still maintaining the temperature, and stirred for 5 hours. The product was extracted three times with dichloromethane (50 $\mathrm{mL}$ each). The resulting organic layers were combined and washed with brine (20 mL). The organic product was dried over $\mathrm{MgSO}_{4}$, filtered under gravity and solvents-removed under reduced pressure to yield $7.226 \mathrm{~g}(84 \%)$ of the target hydrazine which was initially an oil but turned a white solid upon refrigeration. MP: $59-61{ }^{\circ} \mathrm{C} .{ }^{1} \mathrm{H}$ NMR $\left(\mathrm{CDCl}_{3}\right): \delta=1.13(\mathrm{~d}, J=6.3$ $\mathrm{Hz}, 3 \mathrm{H}), 1.17(\mathrm{~d}, J=6.3 \mathrm{~Hz}, 3 \mathrm{H}), 2.74(\mathrm{dd}, J=10.3,13.1 \mathrm{~Hz} 1 \mathrm{H}), 2.83(\mathrm{dd}, J=3.9,13.1 \mathrm{~Hz}, 1 \mathrm{H})$, 2.94 (sept, $J=6.3,12.6 \mathrm{~Hz}, 1 \mathrm{H}), 3.05-3.10(\mathrm{~m}, 1 \mathrm{H}), 3.53-3.58(\mathrm{~m}, 2 \mathrm{H}), 7.17-7.21(\mathrm{~m}, 3 \mathrm{H}), 7.26-$ $7.29(\mathrm{~m}, 2 \mathrm{H}) .{ }^{13} \mathrm{C} \mathrm{NMR}\left(\mathrm{CDCl}_{3}\right): \delta=19.8,20.9,30.0,55.3,63.1,126.1,128.1,129.2,139.5$. 


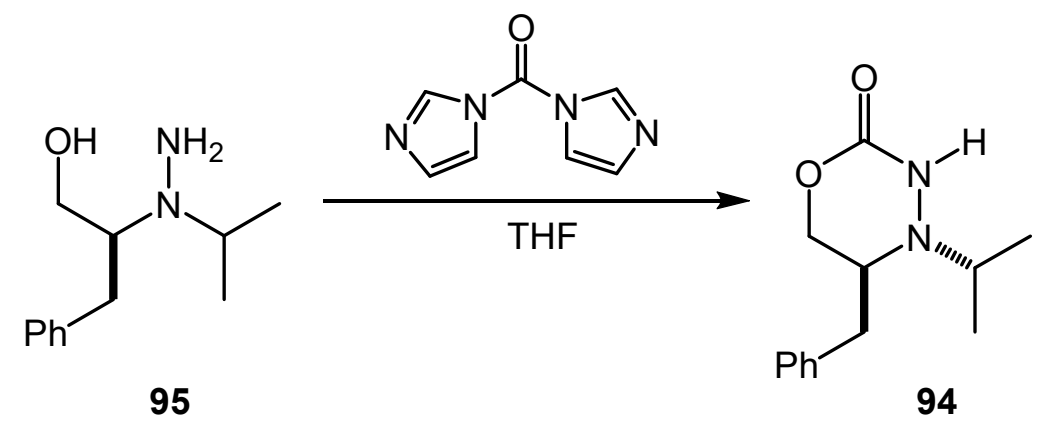

(S)-5-Benzyl-4-Isopropyl-1,3,4-oxadiazinone (94): Tetrahydrofuran (THF) (90 mL) was added to the $\mathrm{N}_{4}$-Isopropyl hydrazine $(7.23 \mathrm{~g}, 34.7 \mathrm{mmol})$ starting material in a nitrogen purged $1 \mathrm{~L}$ round bottomed flask and left to homogenize at room temperature. Carbonyl diimidazole (CDI) (5.91 g, $36.5 \mathrm{mmol}$ ) was then added and left to stir for 18 hours at room temperature. The solution was subjected to rotary evaporation to remove the THF solvent and the resulting viscous oil was diluted with dichloromethane $(120 \mathrm{~mL})$ and washed with $1 \mathrm{M} \mathrm{HCl}(20 \mathrm{~mL})$ and brine $(20$ $\mathrm{mL}$ ). The recovered organic layer was dried over $\mathrm{MgSO}_{4}$, filtered under gravity and solventsremoved under reduced pressure. The crude product was purified by flash column chromatography (hexanes: ethyl acetate, 50:50) to yield $6.28 \mathrm{~g}(77 \%)$ of the $\mathrm{N}_{4-}$ isopropyloxadiazinone target as a light-yellow solid. MP: $90-91{ }^{\circ} \mathrm{C} .{ }^{1} \mathrm{H}$ NMR $\left(\mathrm{CDCl}_{3}\right): \delta=1.02$ $(\mathrm{d}, J=6.2 \mathrm{~Hz}, 3 \mathrm{H}), 1.18(\mathrm{~d}, J=6.2 \mathrm{~Hz}, 3 \mathrm{H}) 2.84(\mathrm{dd}, J=8.7,13.9 \mathrm{~Hz}, 1 \mathrm{H}), 2.95(\mathrm{dd}, J=6.6$, $13.9 \mathrm{~Hz}, 1 \mathrm{H}) 3.02(\mathrm{sxt}, J=6.2,12.4 \mathrm{~Hz}, 1 \mathrm{H}), 3.30-3.33(\mathrm{~m}, 1 \mathrm{H}), 4.08(\mathrm{dd}, J=1.2,11.5 \mathrm{~Hz}, 1 \mathrm{H})$, $4.45(\mathrm{dd}, J=3.5,11.5 \mathrm{~Hz}, 1 \mathrm{H}) 6.84(\mathrm{~s}, 1 \mathrm{H}), 7.21-7.25(\mathrm{~m}, 3 \mathrm{H}), 7.29-7.32(\mathrm{~m}, 2 \mathrm{H}) .{ }^{13} \mathrm{C} \mathrm{NMR}$ $\left(\mathrm{CDCl}_{3}\right): \delta=20.3,20.4,36.9,53.1,55.9,64.3,126.6,128.6,129.3,138.0,152.7 . \mathrm{IR}\left(\mathrm{CCl}_{4}\right)$ : 3514, 1702, 1093, $754 \mathrm{~cm}^{-1}$. ESI-HRMS calcd for $\mathrm{C}_{13} \mathrm{H}_{18} \mathrm{~N}_{2} \mathrm{NaO}_{2}\left(\mathrm{M}+\mathrm{Na}^{+}\right): 257.1260$. Found: 257.1252. 

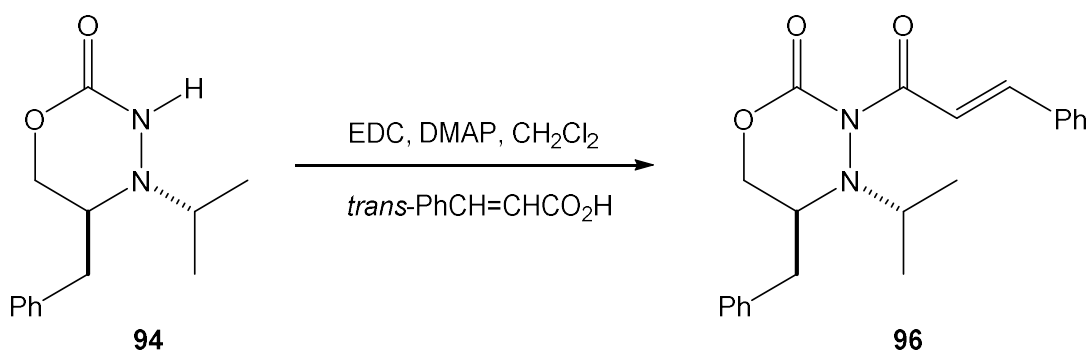

(S)-5-Benzyl-3-trans-cinnamoyl-4-isopropyl-1,3,4-oxadiazinone (96): To a flame-dried nitrogen-purged $500 \mathrm{~mL}$ round bottom flask was added the oxadiazinone substrate $(3.360 \mathrm{~g}$, $14.34 \mathrm{mmol})$ which was dissolved in anhydrous dichloromethane $(80.00 \mathrm{~mL})$. To the solution was added trans-cinnamic acid (2.550 g, $17.21 \mathrm{mmol})$, 1-ethyl-3-(3-dimethylaminopropyl) carbodiimide (EDC) (3.300 g, $17.21 \mathrm{mmol})$, and 4-dimethylaminopyridine (DMAP) catalyst ( $0.440 \mathrm{~g}, 3.585 \mathrm{mmol})$ sequentially. The reaction was allowed to stir for 18 hours at room temperature, after which it was diluted with dichloromethane $(80 \mathrm{~mL})$ and washed with $1 \mathrm{M} \mathrm{HCl}$ $(20 \mathrm{~mL}), 1 \mathrm{M} \mathrm{NaOH}(20 \mathrm{~mL})$ followed by brine $(20 \mathrm{~mL})$ wash. The organic layer thus recovered was dried over magnesium sulfate, gravity filtered, and solvent removed under reduced pressure. The crude product obtained was purified by flash column chromatography (hexane: ethyl acetate, $75: 25)$ to yield $1.564 \mathrm{~g}(30 \%)$ of the title compound as a yellow oil: IR (neat): 1780, 1674, 1623, $1285,1226,733,702 \mathrm{~cm}^{-1}$. The acylated product thus obtained was taken through the conjugate addition reaction without further analysis. 


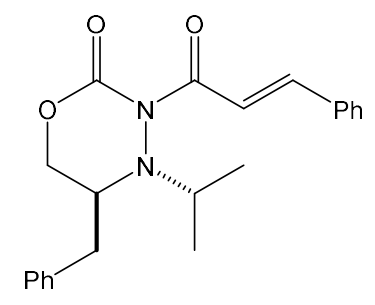

96

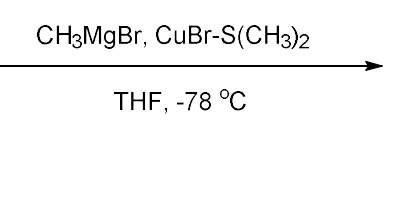

$\mathrm{Ph}$

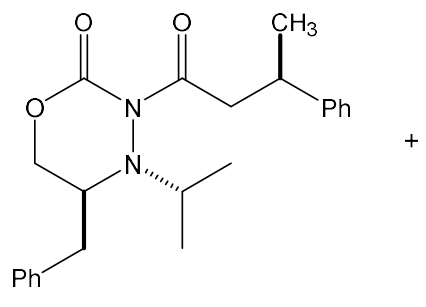

$98 \mathrm{a}$

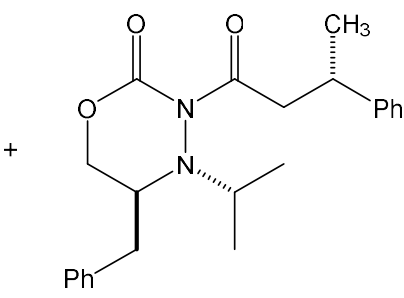

$98 b$

(S)-5-Benzyl-4-isopropyl-3-(3'-phenylbutanoyl)-1,3,4-oxadiazinone (98): To a $100 \mathrm{~mL}$ flame dried, nitrogen purged three-neck round bottomed flask was added copper bromide dimethyl sulfide complex (0.722 g, $3.51 \mathrm{mmol})$, tetrahydrofuran (THF) (4 mL, by syringe) and dimethyl sulfide solvent ( $4 \mathrm{~mL}$, by syringe), one after the other. The reaction was then cooled to a temperature of $-78{ }^{\circ} \mathrm{C}$ in a dry ice/ethanol bath. Methyl magnesium bromide $(1.17 \mathrm{~mL}, 3.51$ mmol) was then carefully added to the solution by syringe and left to stir for 45 minutes at -78 ${ }^{\circ} \mathrm{C}$. The acylated heterocycle $(0.426 \mathrm{~g}, 1.17 \mathrm{mmol})$ was dissolved in THF $(4 \mathrm{~mL})$ and then added by dropwise addition to the reaction vessel via an addition funnel. The reaction was left stirring for 15 hours while it gradually warmed up to room temperature. The reaction was then diluted with ethyl acetate $(80 \mathrm{~mL})$ and washed with $1 \mathrm{M} \mathrm{NaOH}(20 \mathrm{~mL}), 1 \mathrm{M} \mathrm{HCl}(20 \mathrm{~mL})$ and brine solution $(20 \mathrm{~mL})$. The recovered organic layer was dried with magnesium sulfate, filtered under gravity and solvent removed under high vacuum. The crude product obtained was purified by flash column chromatography (hexanes: ethyl acetate, $85: 15)$ to yield $0.211 \mathrm{~g}(47 \%)$ of the titled compound as a colorless oil: ${ }^{1} \mathrm{H} \mathrm{NMR}\left(\mathrm{CDCl}_{3}\right): \delta=0.96$ (app. t, $\left.J=5.9 \mathrm{~Hz}, 6 \mathrm{H}\right), 1.36(\mathrm{~d}, J=$ $7.0 \mathrm{~Hz}, 3 \mathrm{H}), 2.09$ (dd, $J=7.8,13.6 \mathrm{~Hz}, 1 \mathrm{H}), 2.47$ (dd, $J=6.5,13.6 \mathrm{~Hz}, 1 \mathrm{H}), 2.90-2.97$ (m, 2H), 3.14-3.28 (m, 2H), 3.36-3.45 (m, 2H), $4.15(\mathrm{dd}, J=7.0,11.4 \mathrm{~Hz}, 1 \mathrm{H}), 7.15-7.31(\mathrm{~m}, 10 \mathrm{H}) .{ }^{13} \mathrm{C}$ $\operatorname{NMR}\left(\mathrm{CDCl}_{3}\right): \delta=19.6,20.2,22.3,37.3,39.1,43.6,56.9,57.6,68.1,126.6,126.8,127.2,128.5$, 
128.6, 129.3, 137.0, 145.8, 154.0, 172.0. IR (neat): 1789, 1731, 1604, 1289, 1218, 701, $667 \mathrm{~cm}^{-1}$. ESI-HRMS calcd for $\mathrm{C}_{23} \mathrm{H}_{28} \mathrm{~N}_{2} \mathrm{NaO}_{3}\left(\mathrm{M}+\mathrm{Na}^{+}\right)$: 403.1992. Found: 403.1984 . 

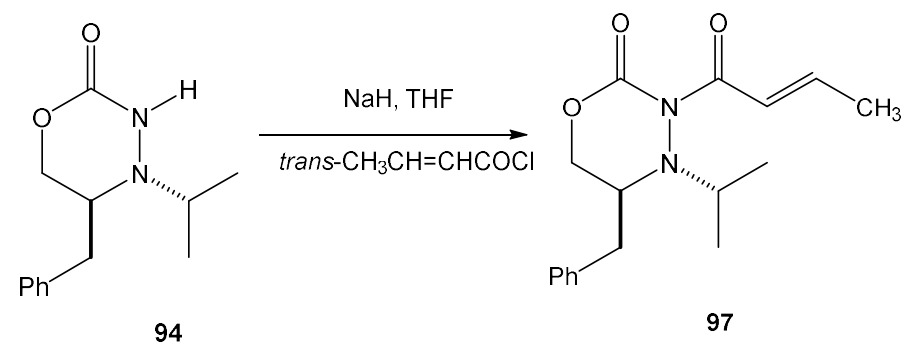

(S)-5-Benzyl-3-trans-crotonyl-4-isopropyl-1,3,4-oxadiazinone (97): To a flame-dried nitrogen-purged $250 \mathrm{~mL}$ round bottom flask was added the oxadiazinone substrate $(1.50 \mathrm{~g}, 6.40$ mmol) which was dissolved in anhydrous dichloromethane $(32.0 \mathrm{~mL})$. To the solution was added the sodium hydride $(0.310 \mathrm{~g}, 12.80 \mathrm{mmol})$. The reaction was allowed to stir for 10 minutes and the crotonyl chloride $(0.64 \mathrm{~mL}, 6.7 \mathrm{mmol})$ was then added. The reaction was left stirring for 18 hours at room temperature, after which it was diluted with dichloromethane $(50 \mathrm{~mL})$ and washed with $1 \mathrm{M} \mathrm{HCl}(20 \mathrm{~mL})$ and brine $(20 \mathrm{~mL})$. The organic layer thus recovered was dried over magnesium sulfate, gravity filtered, and solvent removed under reduced pressure. The title compound was isolated in a yield of $0.345 \mathrm{~g}(18 \%)$ after purification by flash column chromatography (hexanes: ethyl acetate, 75:25). ${ }^{1} \mathrm{H}$ NMR $\left(\mathrm{CDCl}_{3}\right): \delta=1.06(\mathrm{~d}, J=6.3 \mathrm{~Hz}, 6 \mathrm{H})$, $1.95(\mathrm{dd}, J=1.7,6.9 \mathrm{~Hz}, 3 \mathrm{H}), 2.63(\mathrm{dd}, J=7.8,13.7 \mathrm{~Hz}, 1 \mathrm{H}), 2.91(\mathrm{dd}, J=6.7,13.7 \mathrm{~Hz}, 1 \mathrm{H})$, $3.11(\mathrm{p}, J=6.2 \mathrm{~Hz}, 1 \mathrm{H}), 3.65(\mathrm{p}, J=7.3 \mathrm{~Hz}, 1 \mathrm{H}), 3.90(\mathrm{dd}, J=7.7,11.6 \mathrm{~Hz}, 1 \mathrm{H}), 4.40(\mathrm{dd}, J=$ 6.9, $11.6 \mathrm{~Hz}, 1 \mathrm{H}) 6.80(\mathrm{dq}, J=1.6,15.2 \mathrm{~Hz}, 1 \mathrm{H}), 7.16(\mathrm{dq}, J=6.9,15.2 \mathrm{~Hz}, 1 \mathrm{H}), 7.20-7.23(\mathrm{~m}$, 2H), 7.25-7.26 (m, 1H), 7.30-7.33 (m, 2H). 

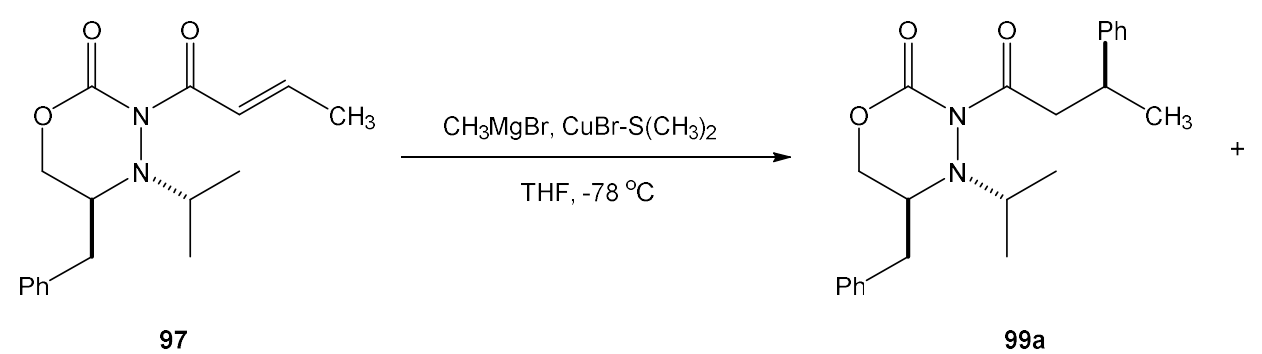

$99 a$

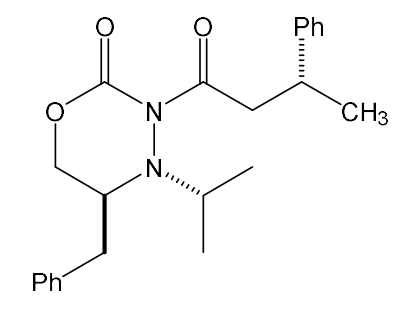

$99 b$

(S)-5-Benzyl-4-isopropyl-3-(3'-phenylbutanoyl)-1,3,4-oxadiazinone (99): To a $100 \mathrm{~mL}$ flame dried, nitrogen purged three-neck round bottomed flask was added copper bromide dimethyl sulfide complex (0.703 g, $3.42 \mathrm{mmol})$, tetrahydrofuran (THF) (4 mL) by syringe and dimethyl sulfide solvent $(4 \mathrm{~mL})$ by syringe, one after the other. The reaction was then cooled to a temperature of $-78{ }^{\circ} \mathrm{C}$ in a dry ice/ethanol bath. Phenylmagnesium bromide $(1.14 \mathrm{~mL}, 3.42$ mmol) was then carefully added to the solution by syringe and left to stir for 45 minutes at -78 ${ }^{\circ} \mathrm{C}$. The substrate (97) (0.345 $\left.\mathrm{g}, 1.14 \mathrm{mmol}\right)$ was dissolved in THF (4 mL) and then added by dropwise addition to the reaction vessel via an addition funnel. The reaction was left stirring for 15 hours while it gradually warmed up to room temperature. The reaction was then diluted with ethyl acetate $(80 \mathrm{~mL})$ and washed with $1 \mathrm{M} \mathrm{NaOH}(20 \mathrm{~mL}), 1 \mathrm{M} \mathrm{HCl}(20 \mathrm{~mL})$ and brine solution $(20 \mathrm{~mL})$. The recovered organic layer was dried with magnesium sulfate and filtered under gravity followed by the removal of the solvent under high vacuum. The crude product obtained was purified by flash column chromatography (hexanes: ethyl acetate, $85: 15$ ) to yield $0.306 \mathrm{~g}$ $(70 \%)$ of the titled compound as a yellow oil. ${ }^{1} \mathrm{H} \mathrm{NMR}\left(\mathrm{CDCl}_{3}\right): \delta=0.96$ (app. t, $J=5.8 \mathrm{~Hz}$, $6 \mathrm{H}), 1.36(\mathrm{~d}, J=7.0 \mathrm{~Hz}, 3 \mathrm{H}), 2.09(\mathrm{dd}, J=7.8,13.5 \mathrm{~Hz}, 1 \mathrm{H}), 2.47(\mathrm{dd}, J=6.4,13.5 \mathrm{~Hz}, 1 \mathrm{H})$, 2.89-3.03 (m, 2H), 3.14-3.28 (m, 2H), 3.36-3.69 (m, 2H), $4.15(\mathrm{dd}, J=7.0,11.5 \mathrm{~Hz}, 1 \mathrm{H}), 7.22-$ $7.26(\mathrm{~m}, 3 \mathrm{H}), 7.27-7.30(\mathrm{~m}, 3 \mathrm{H}) .{ }^{13} \mathrm{C} \mathrm{NMR}\left(\mathrm{CDCl}_{3}\right): \delta=19.6,20.3,21.8,35.9,39.1,43.5,57.2$ 57.8, 68.0, 126.4, 126.9, 127.1, 128.5, 128.7, 129.2, 136.8, 145.9, 152.9, 172.5. IR (neat): 1786, 
1724, 1604, 1218, 759, $701 \mathrm{~cm}^{-1}$. ESI-HRMS calcd for $\mathrm{C}_{23} \mathrm{H}_{28} \mathrm{~N}_{2} \mathrm{NaO}_{3}\left(\mathrm{M}+\mathrm{Na}^{+}\right): 403.1992$. Found: 403.1982. 


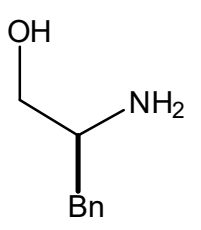

85

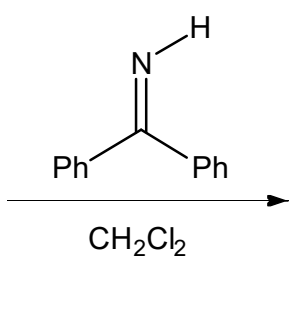

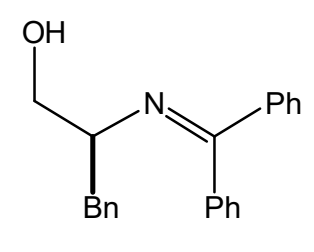

imine

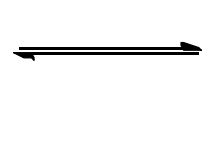

112

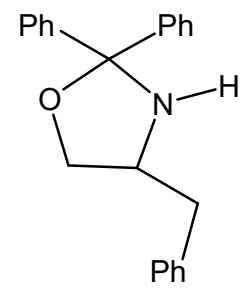

oxazolidine

Benzophenone imine of phenylalaninol (112): To a 1,000 mL, flame dried, nitrogen purged round bottom flask was added anhydrous dichloromethane $(250 \mathrm{~mL})$, Benzophenone imine $(11.7$ $\mathrm{mL}, 69.4 \mathrm{mmol})$ and L-Phenyl alaninol $(10.0 \mathrm{~g}, 66.1 \mathrm{mmol})$ sequentially, and left to stir for 24 hours at room temperature. The reaction was then washed with brine $(20 \mathrm{~mL})$, dried over $\mathrm{MgSO}_{4}$, filtered under gravity and solvents-removed under high vacuum. The target benzophenone imine of phenylalaninol was isolated as a yellow solid which was recrystallized with ethyl acetate $(30 \mathrm{~mL})$ and hexane $(2 \mathrm{~mL})$. The pure yellow crystals were recovered by vacuum filtration and washed with hexanes and air-dried at room temperature. First and second seeds were obtained which yielded a total amount of $20.12 \mathrm{~g}(97 \%)$ of the title compound as a white solid: $\mathrm{MP}: 121-124{ }^{\circ} \mathrm{C} ;{ }^{1} \mathrm{H} \mathrm{NMR}\left(\mathrm{CDCl}_{3}\right): \delta=2.13(\mathrm{~s}, 1 \mathrm{H}), 2.84(\mathrm{dq}, J=5.4,7.8 \mathrm{~Hz}, 2 \mathrm{H})$, 3.66-3.71 (m, 2H), 3.77-3.91 (m, 1H), $6.64(\mathrm{~d}, J=7.1 \mathrm{~Hz}, 2 \mathrm{H})$ 6.94-6.96 (m, 2H), 7.12-7.20 (m, 3H), 7.26-7.39 (m, 6H), 7.55-7.62 (m, 2H). ${ }^{13} \mathrm{C} \mathrm{NMR}\left(\mathrm{CDCl}_{3}\right): \delta=39.1,39.8,59.6,65.5,66.2$, $70.5,100.0,125.8,126.0,126.3,126.5,127.4,127.6,127.8,128.1,128.2,128.3,128.6,128.9$, $129.8,130.1,136.7,138.6,138.9,139.7,144.6,169.8$. IR $\left(\mathrm{CHCl}_{3}\right): 3232,1620,1294,732,700$ $\mathrm{cm}^{-1}$. ESI-HRMS calcd for $\mathrm{C}_{23} \mathrm{H}_{28} \mathrm{~N}_{2} \mathrm{NaO}_{3}\left(\mathrm{M}+\mathrm{Na}^{+}\right)$: 338.1515 . Found: 338.1505 . 


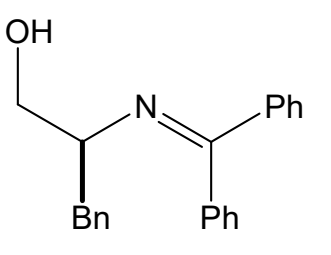

112

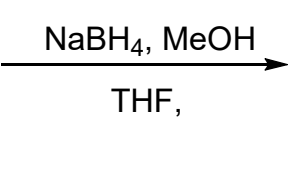

$\sqrt{2}$

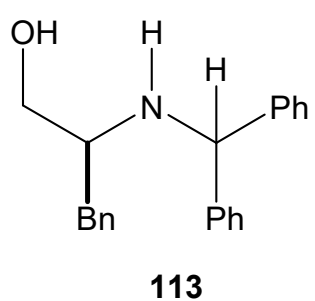

113

L-N-diphenylmethyl phenylalaninol (113) : To a $250 \mathrm{~mL}$ flame dried, nitrogen purged round bottom flask was added Benzophenone imine of phenylalaninol (4.00 g, $12.7 \mathrm{mmol})$, tetrahydrofuran (THF) $(20 \mathrm{~mL})$, methanol $(20 \mathrm{~mL})$ and sodium borohydride $\left(\mathrm{NaBH}_{4}\right)(0.72 \mathrm{~g}$, $19.0 \mathrm{mmol}$ ) sequentially, and left to stir for 1 hour at room temperature, after which the solution was placed on rotary evaporator to remove the methanol. The concentrated solution was then diluted with dichloromethane $(80 \mathrm{~mL})$ and washed with $1 \mathrm{M} \mathrm{NaOH}(20 \mathrm{~mL})$ and brine $(20 \mathrm{~mL})$. The organic layer was dried over $\mathrm{MgSO}_{4}$, filtered under gravity and solvents-removed under high vacuum to yield $3.89 \mathrm{~g}(97 \%)$ of the title compound as a colorless viscous oil: ${ }^{1} \mathrm{H}$ NMR $\left(\mathrm{CDCl}_{3}\right): \delta=2.74(\mathrm{dd}, J=6.0,12.7 \mathrm{~Hz}, 1 \mathrm{H}), 2.82-2.91(\mathrm{~m}, 2 \mathrm{H}), 3.34(\mathrm{dd}, J=4.5,10.7 \mathrm{~Hz}, 1 \mathrm{H})$, $3.60(\mathrm{dd}, J=3.4,10.7 \mathrm{~Hz}, 1 \mathrm{H}) 4.92(\mathrm{~s}, 1 \mathrm{H}), 7.07-7.14(\mathrm{~m}, 4 \mathrm{H}), 7.17-7.25(\mathrm{~m}, 5 \mathrm{H}), 7.27-7.33(\mathrm{~m}$, $6 \mathrm{H}) .{ }^{13} \mathrm{C} \mathrm{NMR}\left(\mathrm{CDCl}_{3}\right): 38.4,57.5,63.1,64.1,126.4,127.1,127.17,127.2,127.4,128.1,128.6$, 129.3, 129.8, 138.5, 143.58, 143.59. IR $\left(\mathrm{CHCl}_{3}\right): 3328,1600,1030,745,700 \mathrm{~cm}^{-1}$. 
<smiles>OCC(Br)NC(c1ccccc1)c1ccccc1</smiles>

113

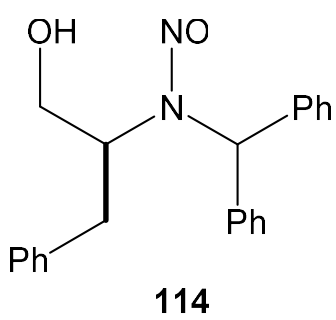

114

N- N4-diphenylmethyl-N4-nitroso-L-phenyl-alaninol. (114): To the $\mathrm{N}_{4}$-isopropyl-L-phenylalaninol $(0.953 \mathrm{~g}, 3.00 \mathrm{mmol})$ starting material in a $1 \mathrm{~L}$ round bottomed flask was added Sodium nitrite (NaNO2) (4.00 g, $58.0 \mathrm{mmol}), 3 \mathrm{M} \mathrm{HCl}(22 \mathrm{~mL})$ and tetrahydrofuran (THF) (50 mL) and stirred for 18 hours at room temperature. The reaction was diluted with ethylacetate $(150 \mathrm{~mL})$ and washed with brine. The organic product was dried over MgSO4, filtered under gravity and solvents-removed under reduced pressure to yield $9.15 \mathrm{~g}(94 \%)$ of the titled compound as a yellow solid: $87-90{ }^{\circ} \mathrm{C} .{ }^{1} \mathrm{H} \mathrm{NMR}\left(\mathrm{CDCl}_{3}\right): \delta=2.84(\mathrm{dd}, J=4.9,13.3 \mathrm{~Hz}, 1 \mathrm{H}), 3.23(\mathrm{dd}, J=10.2$, $13.3 \mathrm{~Hz}, 1 \mathrm{H}), 3.87$ (dd, $J=5.2,12.2 \mathrm{~Hz}, 1 \mathrm{H}) 3.96(\mathrm{dd}, J=3.2,12.2 \mathrm{~Hz}, 1 \mathrm{H}), 4.06-4.13(\mathrm{~m}, 1 \mathrm{H})$, $6.40(\mathrm{~s}, 1 \mathrm{H}), 6.81-6.83(\mathrm{~m}, 2 \mathrm{H}), 7.10-7.38(\mathrm{~m}, 13 \mathrm{H}) .{ }^{13} \mathrm{C} \mathrm{NMR}\left(\mathrm{CDCl}_{3}\right)$ : (mixture of diastereomers), $\delta=33.9,38.8,61.4,63.7,69.6,76.8,77.1,77.4,126.8,126.9,128.00,128.05$, $128.1,128.2,128.5,128.6,128.7,128.73,128.8,128.83,128.9,129.1,129.3,129.9,136.6,137.1$, 137.2, 138.9, 139.1; IR $\left(\mathrm{CHCl}_{3}\right): 3432,3065,1603,1454,1141,733,701 \mathrm{~cm}^{-1}$. ESI-HRMS calcd for $\mathrm{C}_{22} \mathrm{H}_{22} \mathrm{~N}_{2} \mathrm{NaO}_{2}\left(\mathrm{M}+\mathrm{Na}^{+}\right)$: 369.1579. Found: 369.1570 . 
APPENDIX B: SELECTED NMR SPECTRA 
$500 \mathrm{MHz}{ }^{1} \mathrm{H}$ NMR spectrum of compound 34

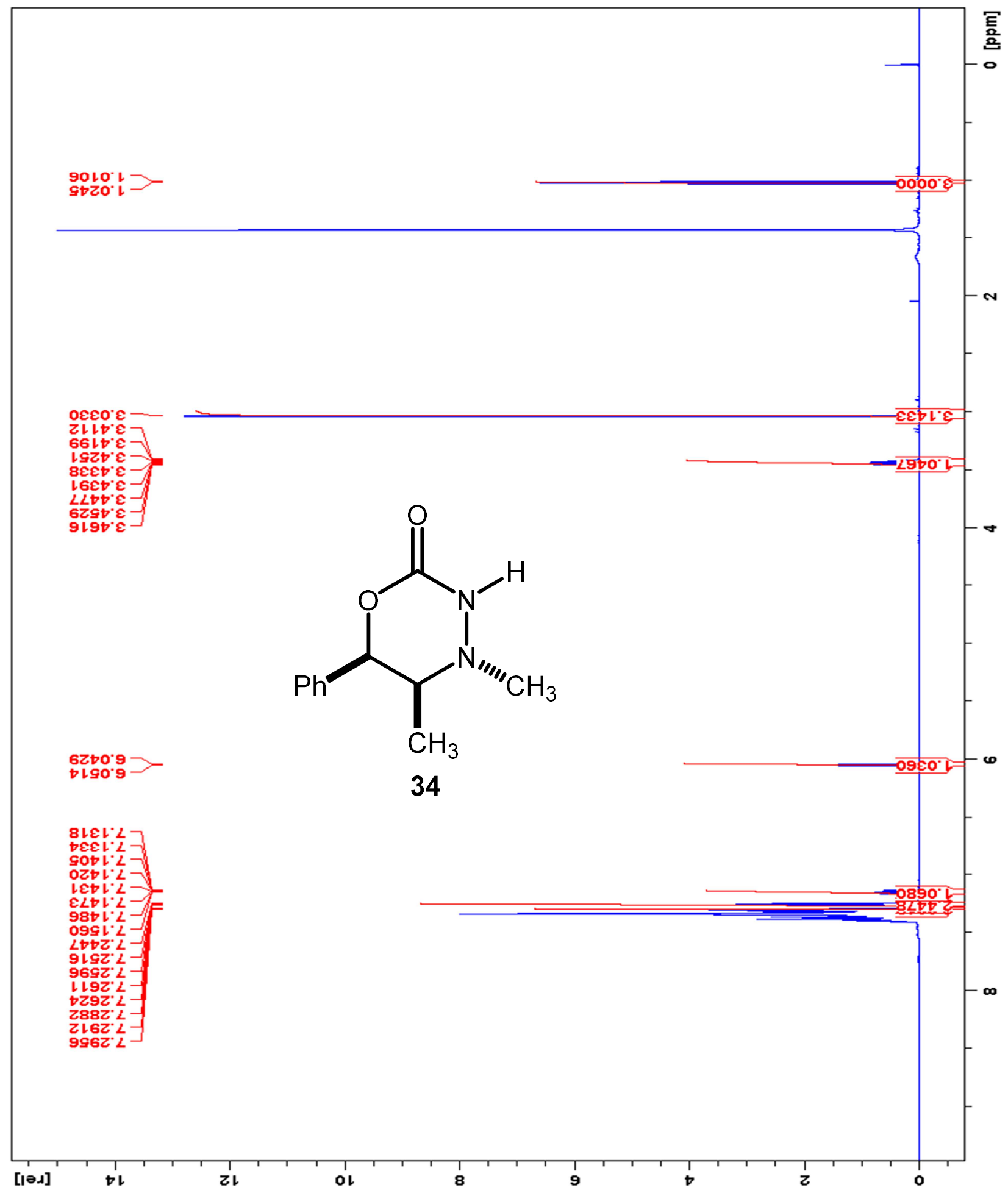


$100 \mathrm{MHz}{ }^{13} \mathrm{C}$ NMR spectrum of compound 34

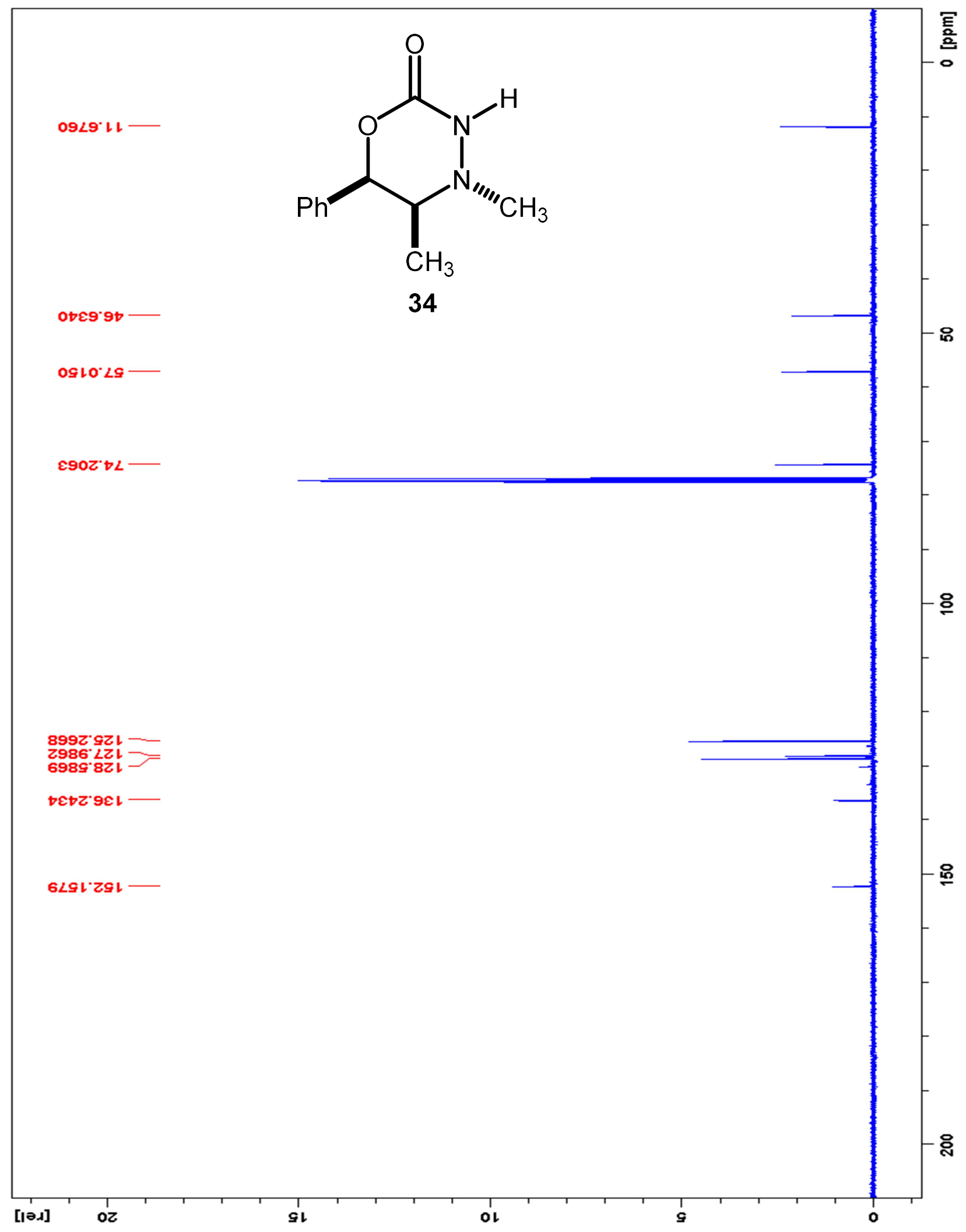


$500 \mathrm{MHz}{ }^{1} \mathrm{H}$ NMR spectrum of compound 43

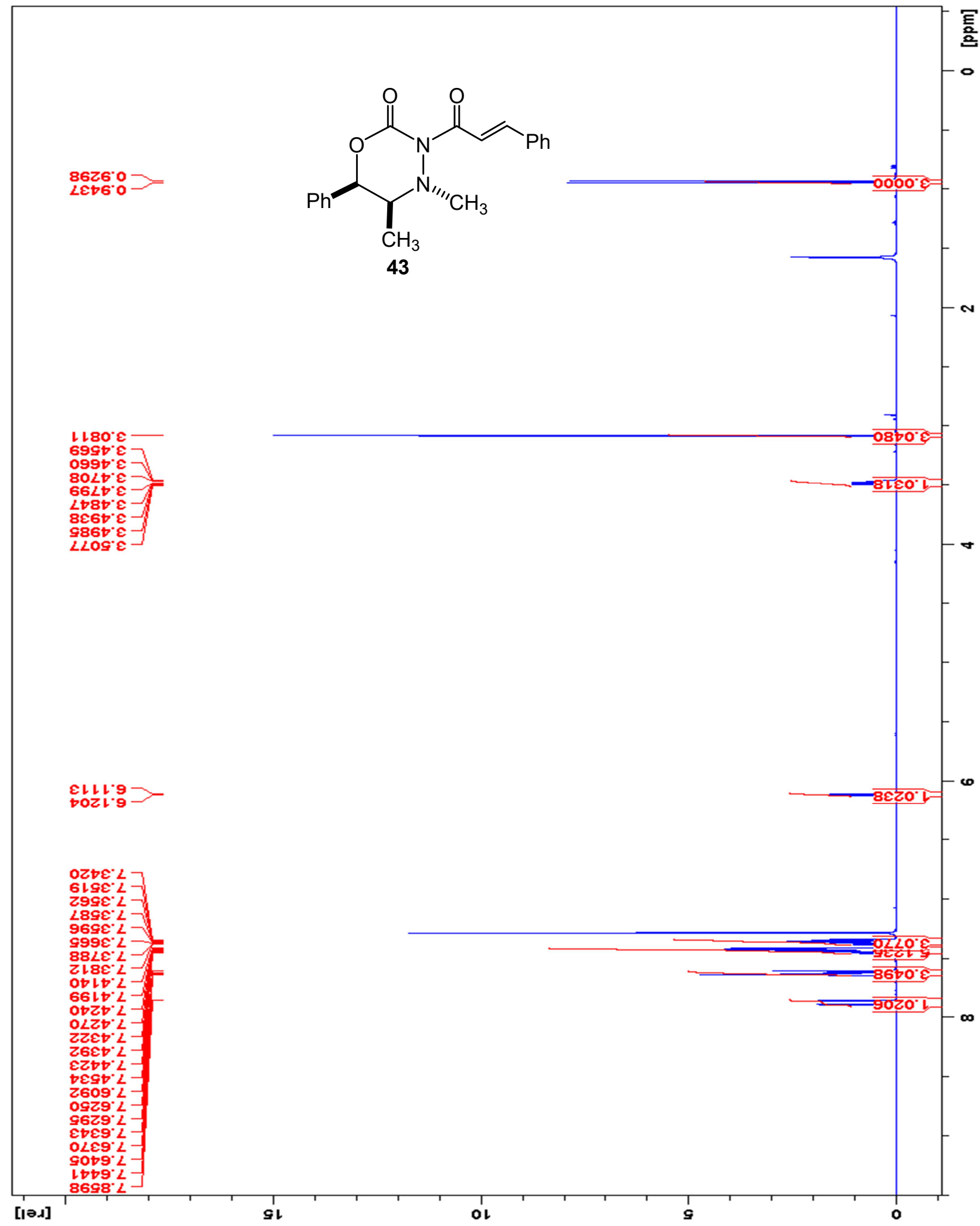


$125 \mathrm{MHz}{ }^{13} \mathrm{C}$ NMR spectrum of compound $\mathbf{4 3}$

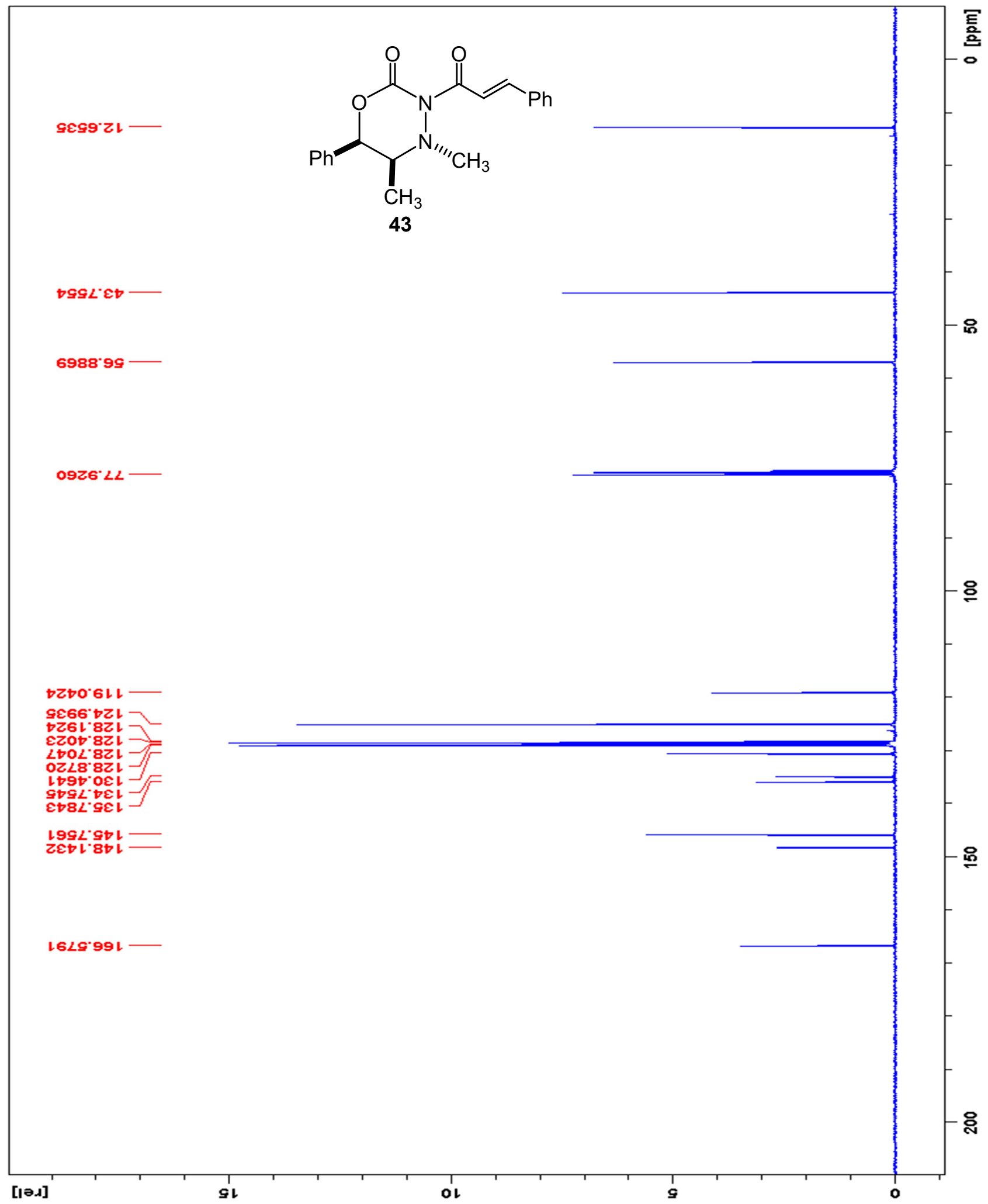


$500 \mathrm{MHz}{ }^{1} \mathrm{H}$ NMR spectrum of compound $\mathbf{5 9}$

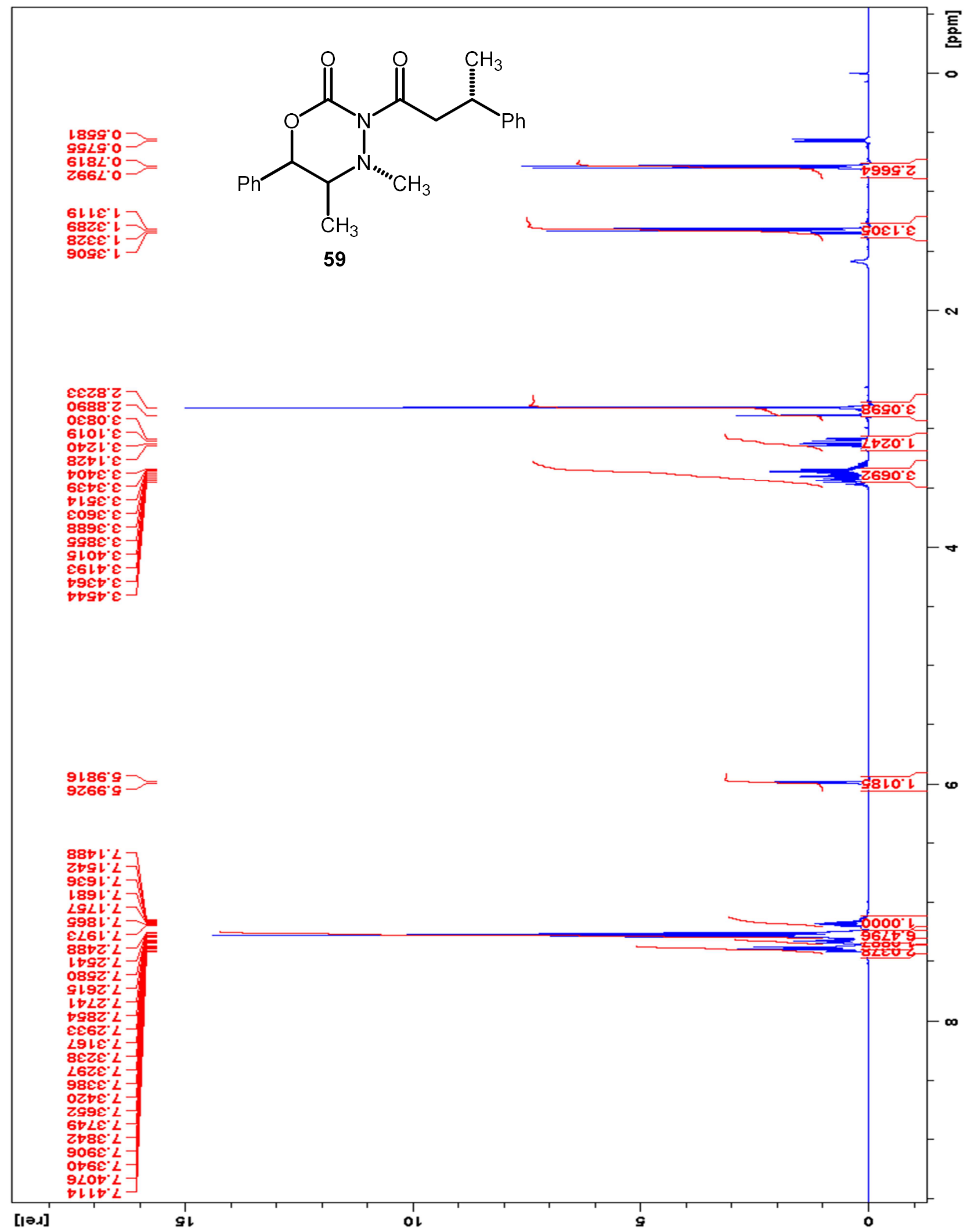


$100 \mathrm{MHz}{ }^{13} \mathrm{C}$ NMR spectrum of compound $\mathbf{5 9}$

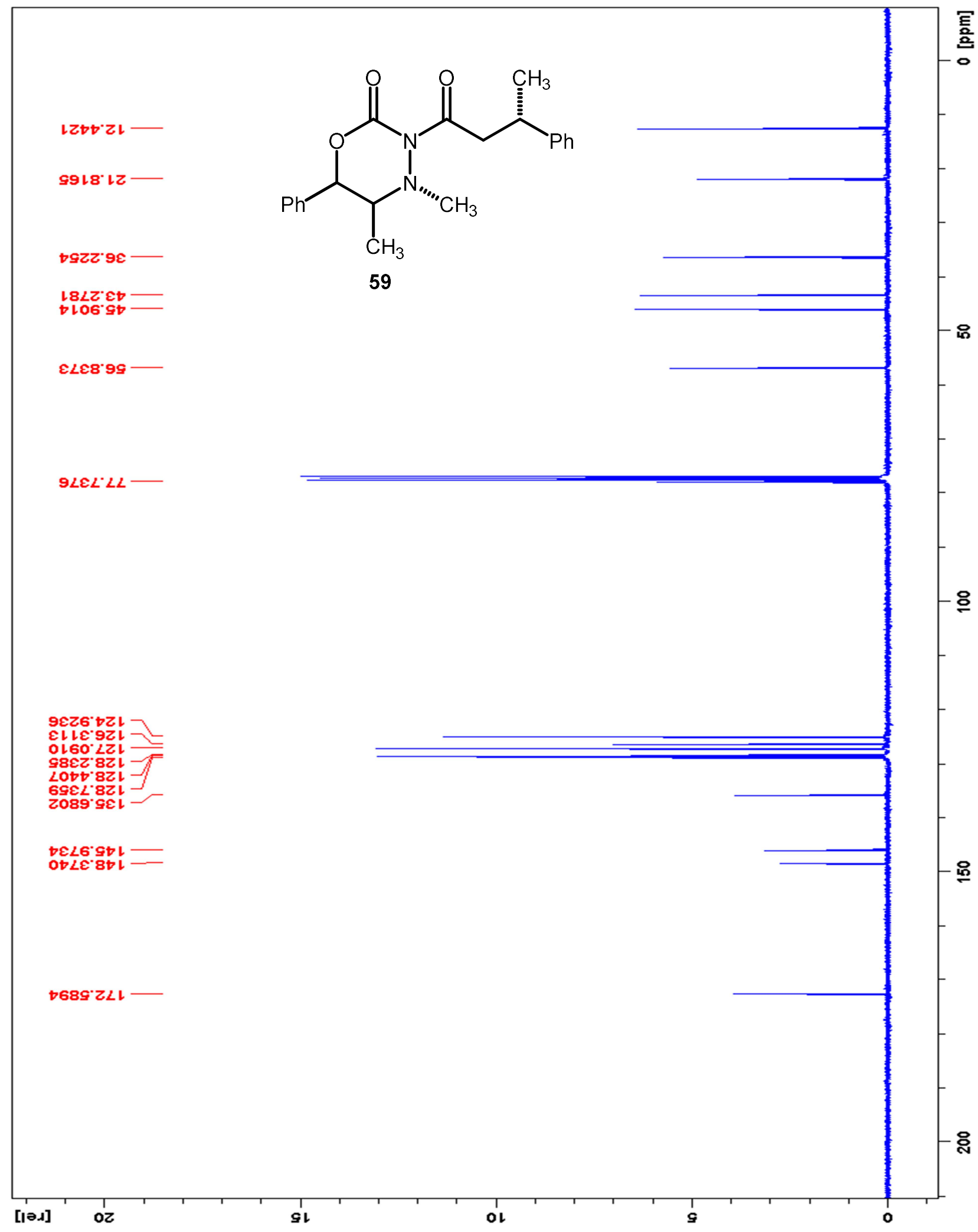


$500 \mathrm{MHz}{ }^{1} \mathrm{H}$ NMR spectrum of compound $\mathbf{6 0 a}$

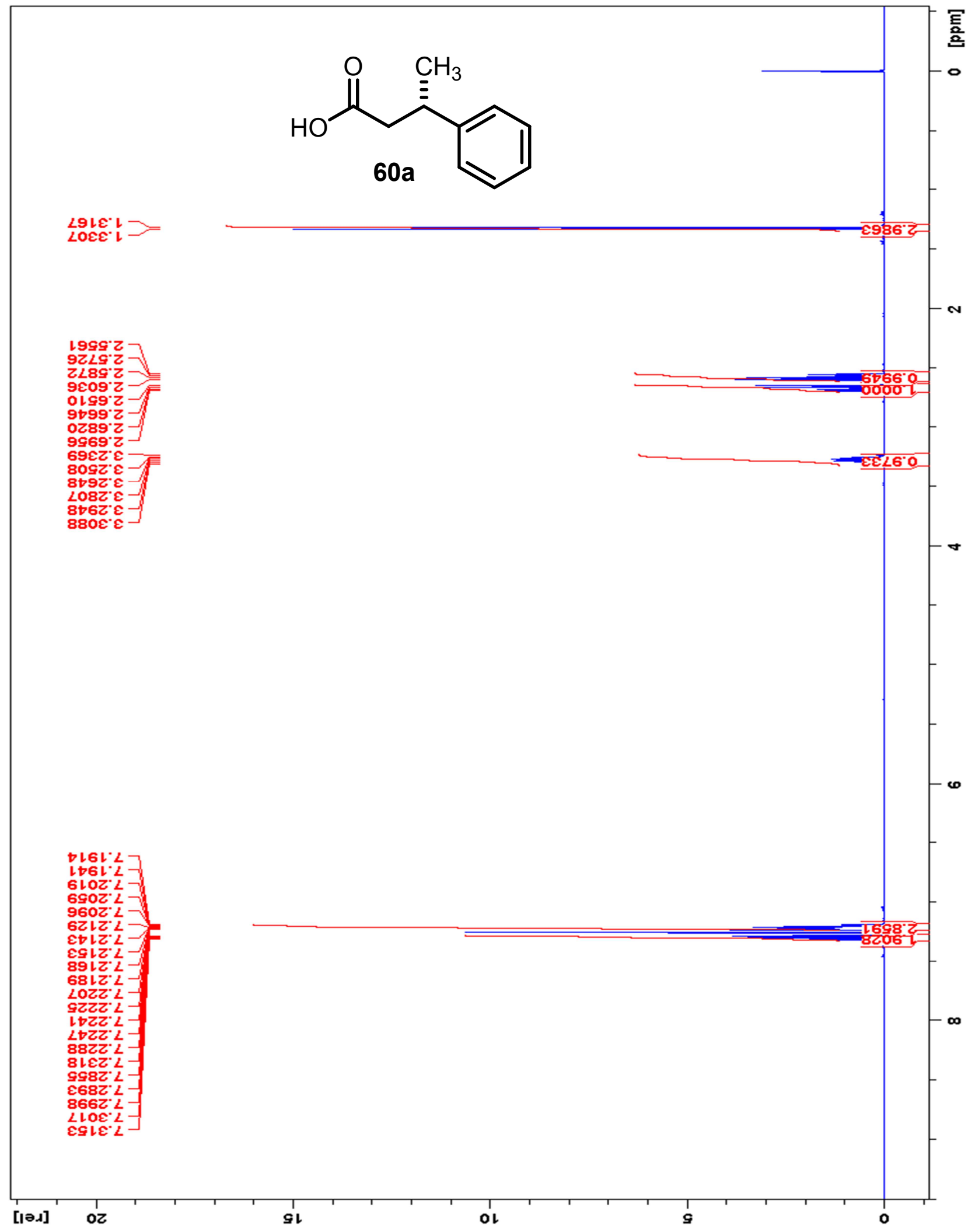


$125 \mathrm{MHz}{ }^{13} \mathrm{C}$ NMR spectrum of compound $\mathbf{6 0 a}$

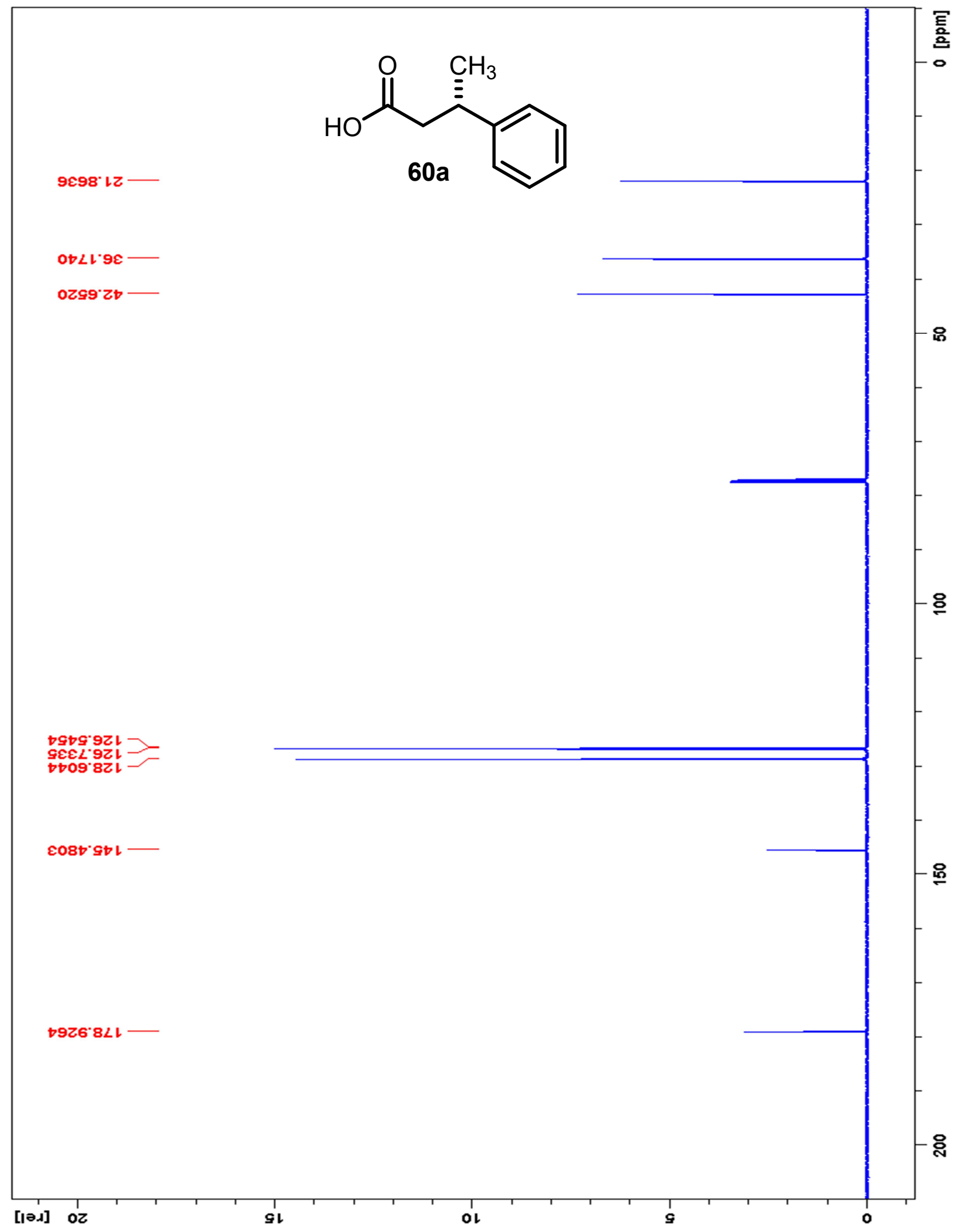


$500 \mathrm{MHz}{ }^{1} \mathrm{H}$ NMR spectrum of compound 70

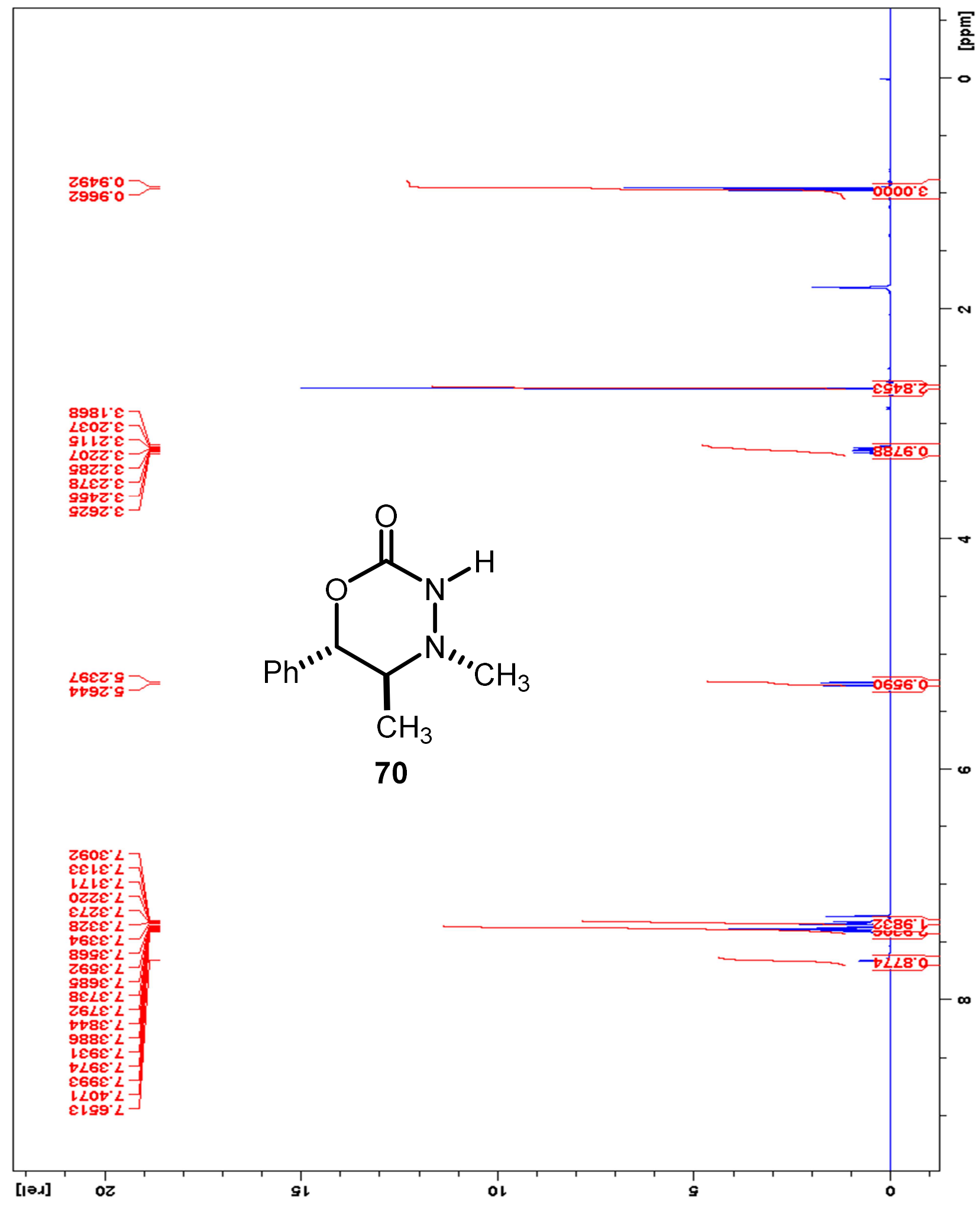


$100 \mathrm{MHz}{ }^{13} \mathrm{C}$ NMR spectrum of compound 70

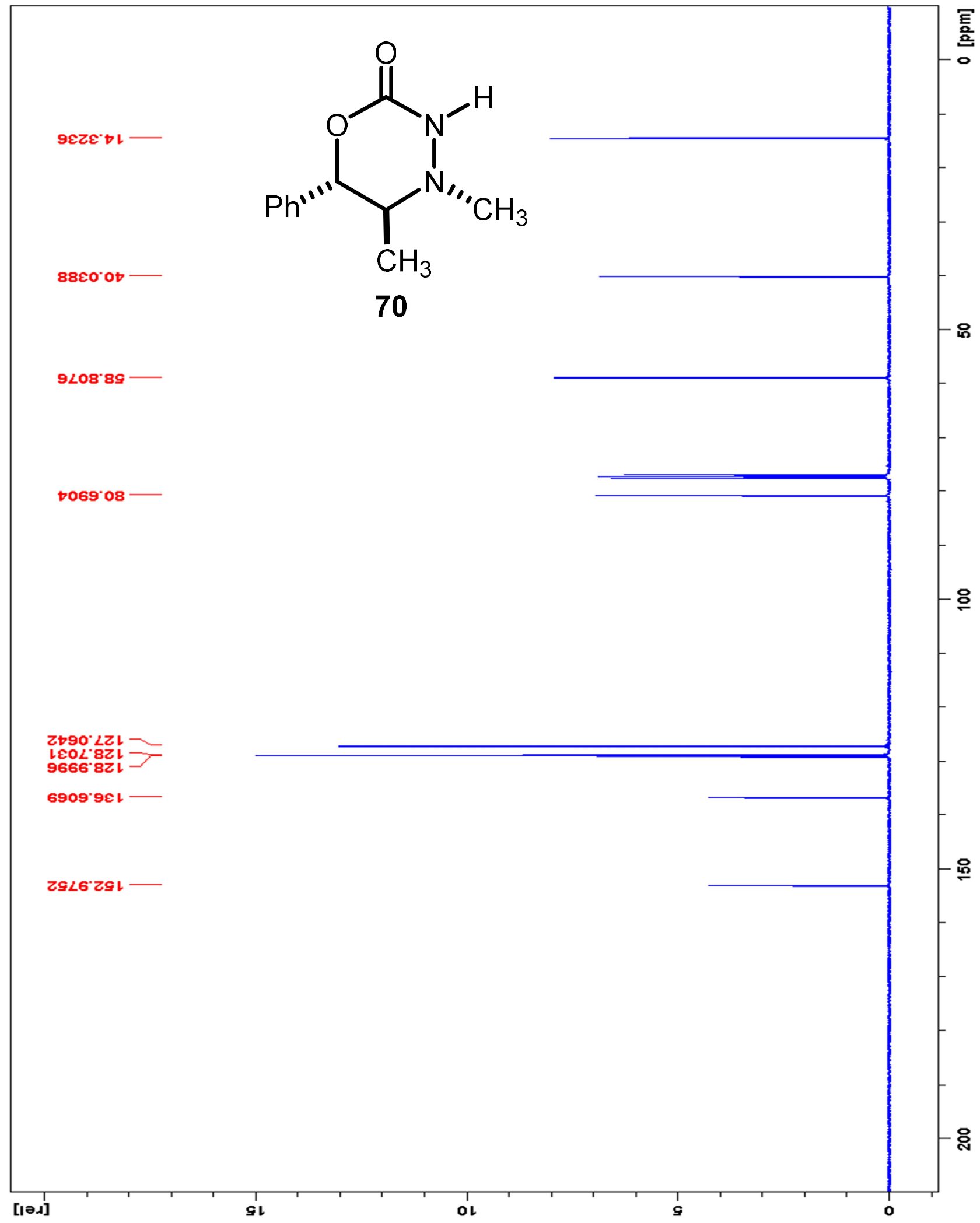


$500 \mathrm{MHz}{ }^{1} \mathrm{H}$ NMR spectrum of compound 71

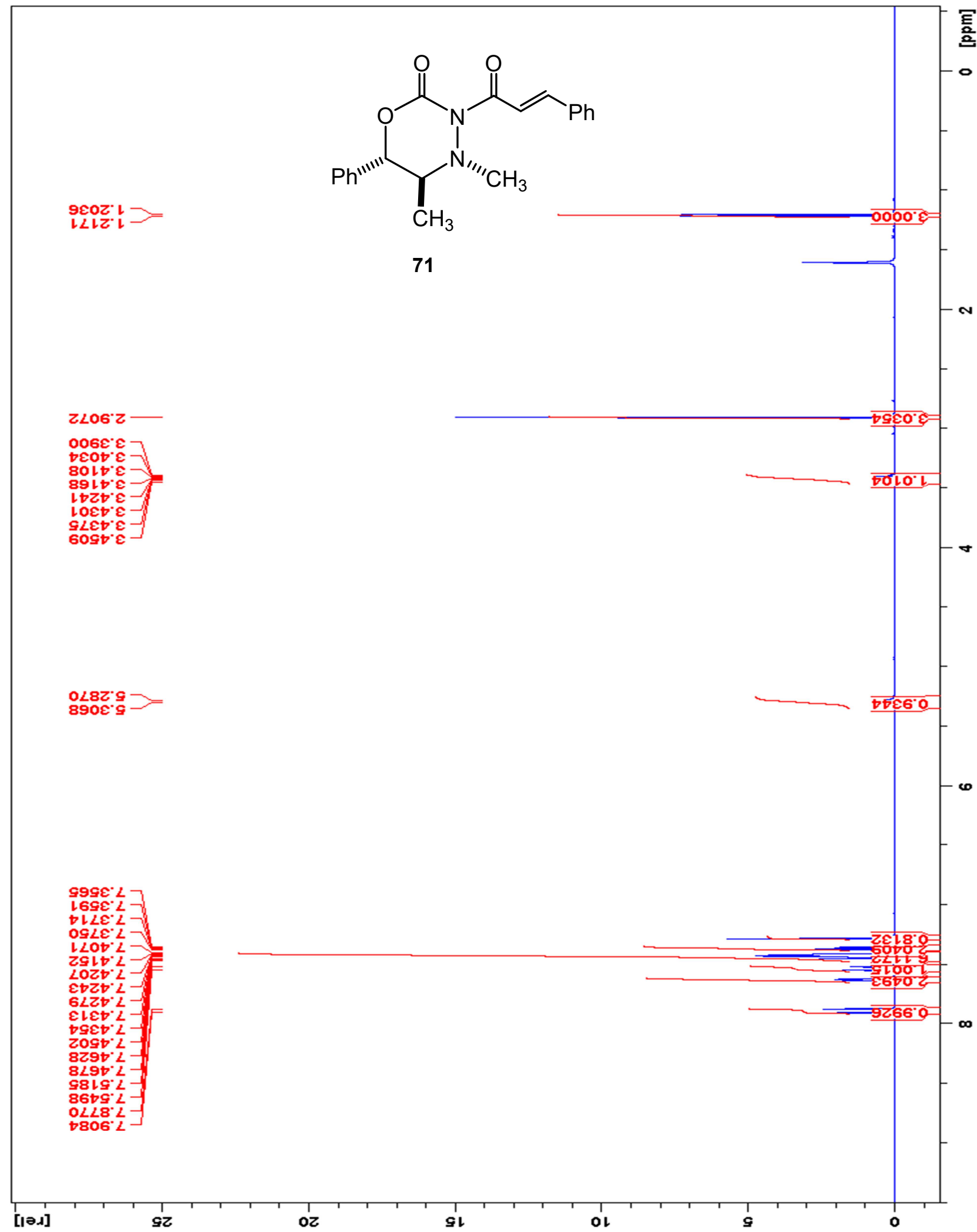


$125 \mathrm{MHz}{ }^{13} \mathrm{C}$ NMR spectrum of compound 71 with line broadening

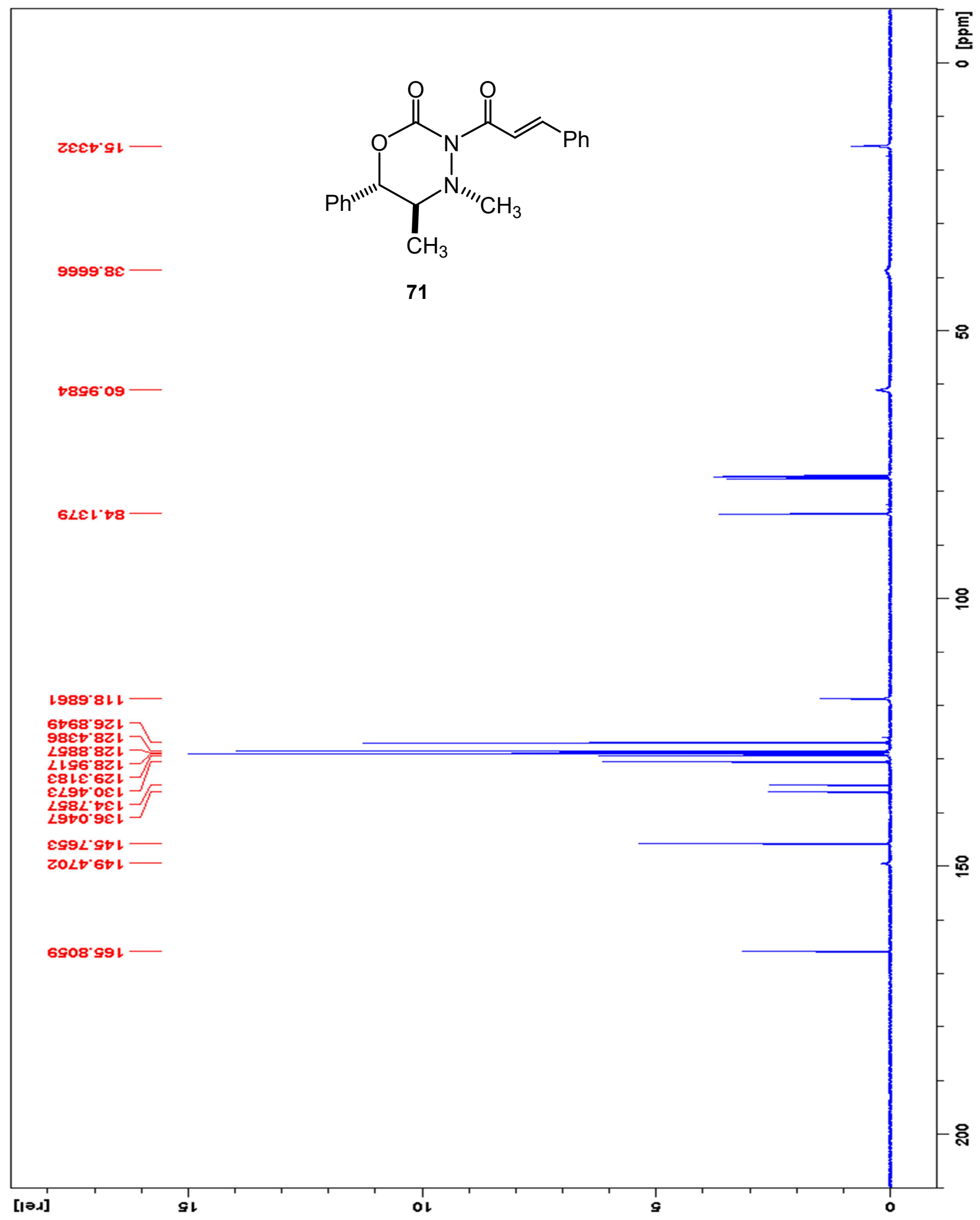


$500 \mathrm{MHz}{ }^{1} \mathrm{H}$ NMR spectrum of compound 72

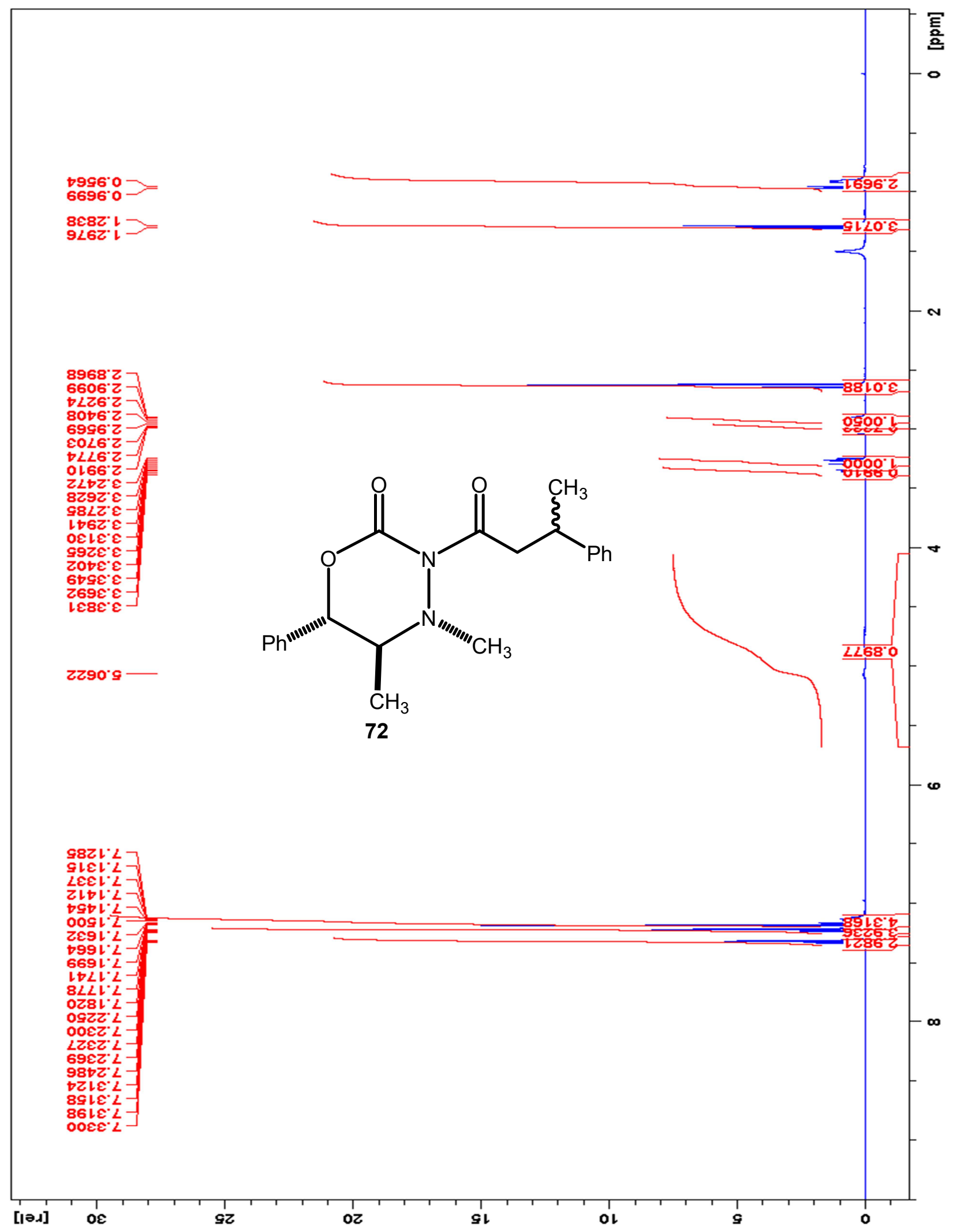


$100 \mathrm{MHz}{ }^{13} \mathrm{C}$ NMR spectrum of compound 72 with line broadening

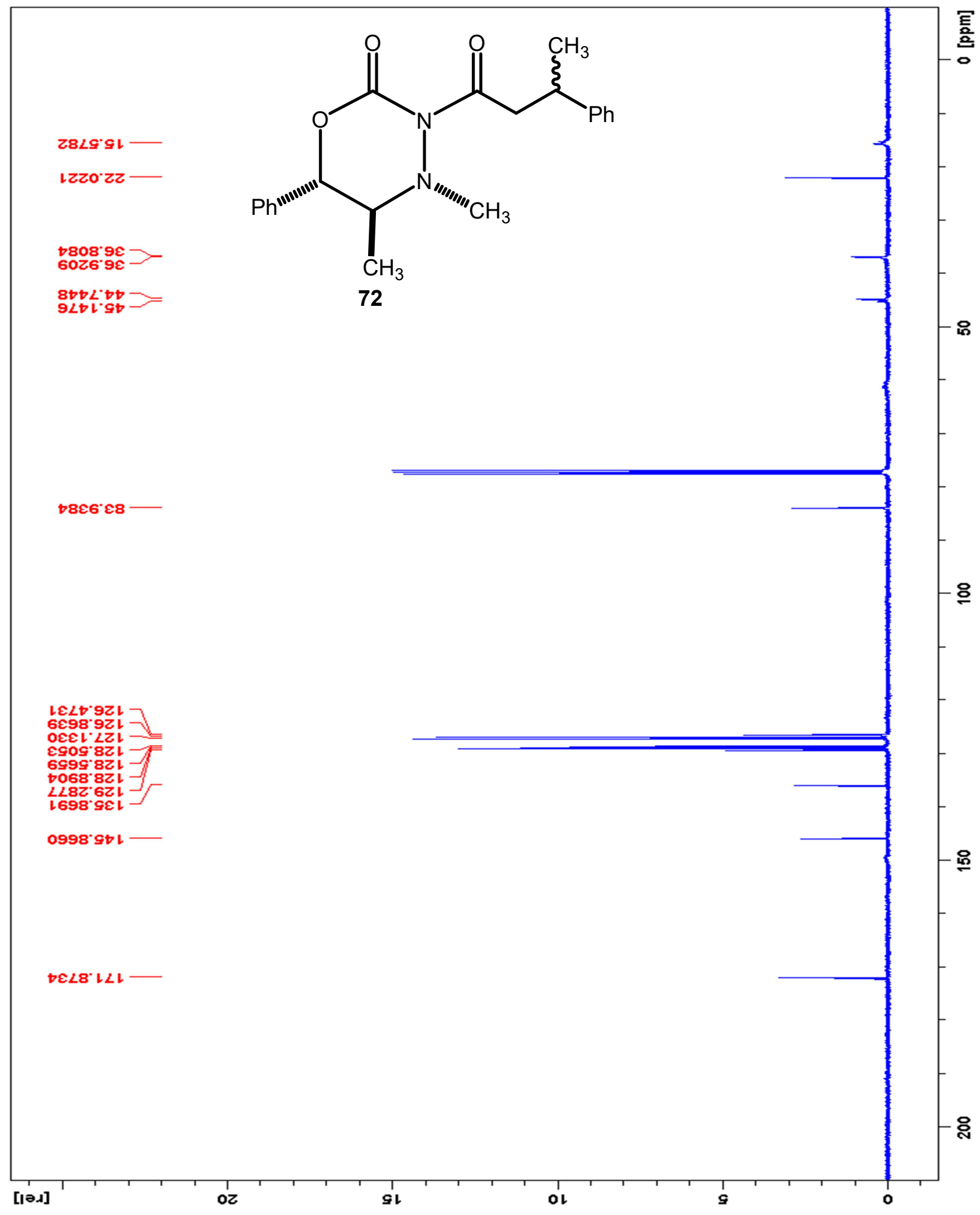


$500 \mathrm{MHz}{ }^{1} \mathrm{H}$ NMR spectrum of compound 78

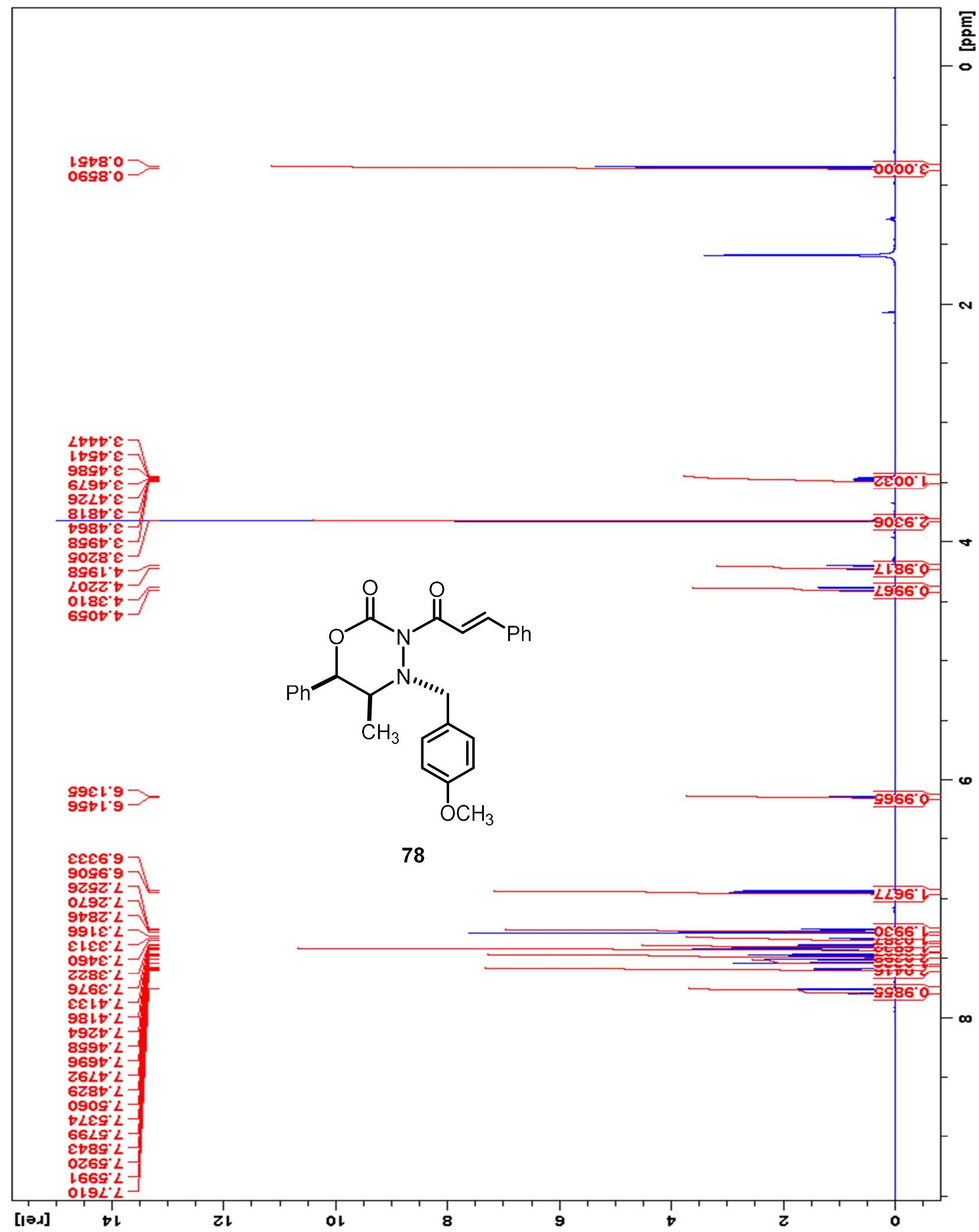


$125 \mathrm{MHz}{ }^{13} \mathrm{C}$ NMR spectrum of compound 78

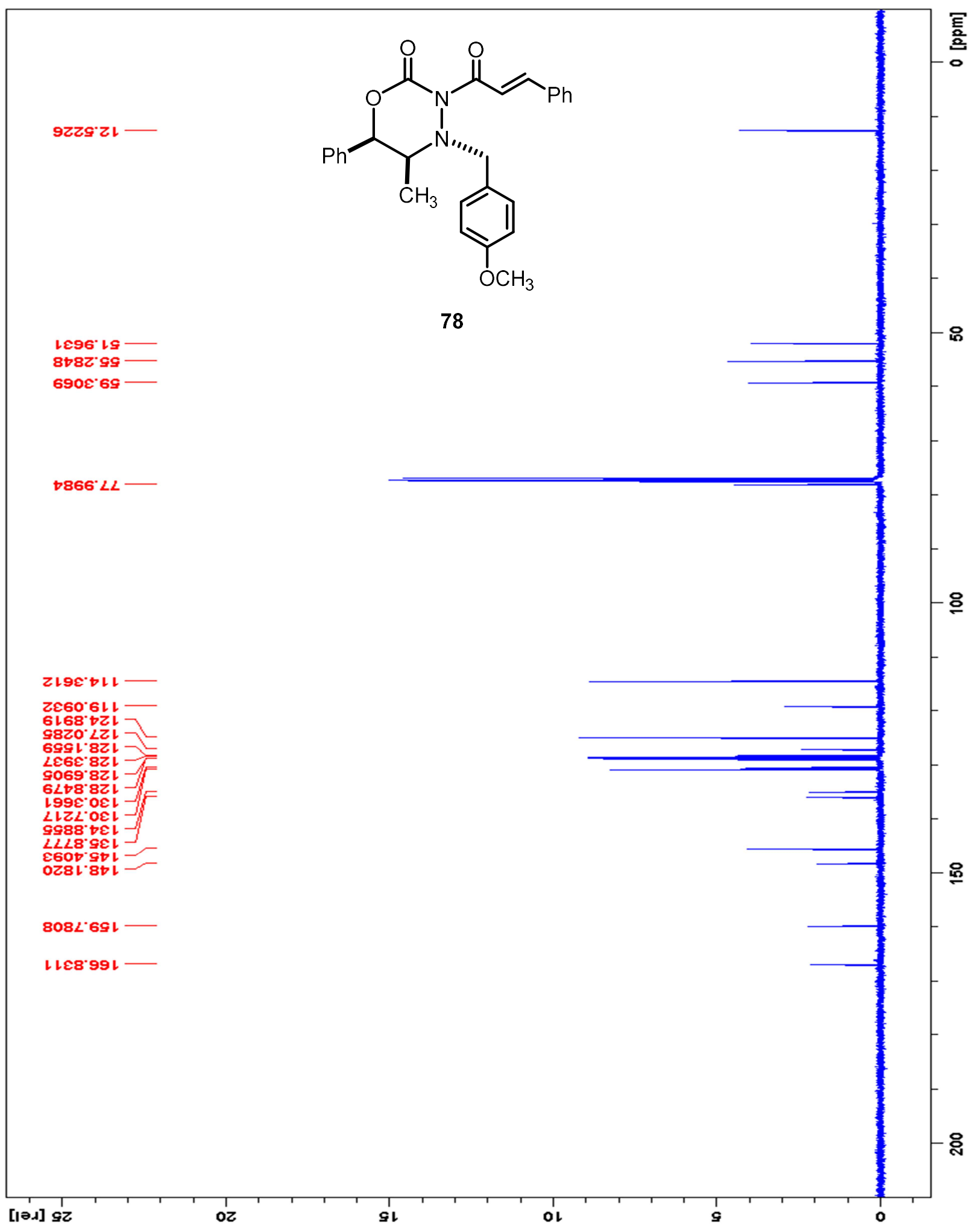


$500 \mathrm{MHz}{ }^{1} \mathrm{H}$ NMR spectrum of compound 81

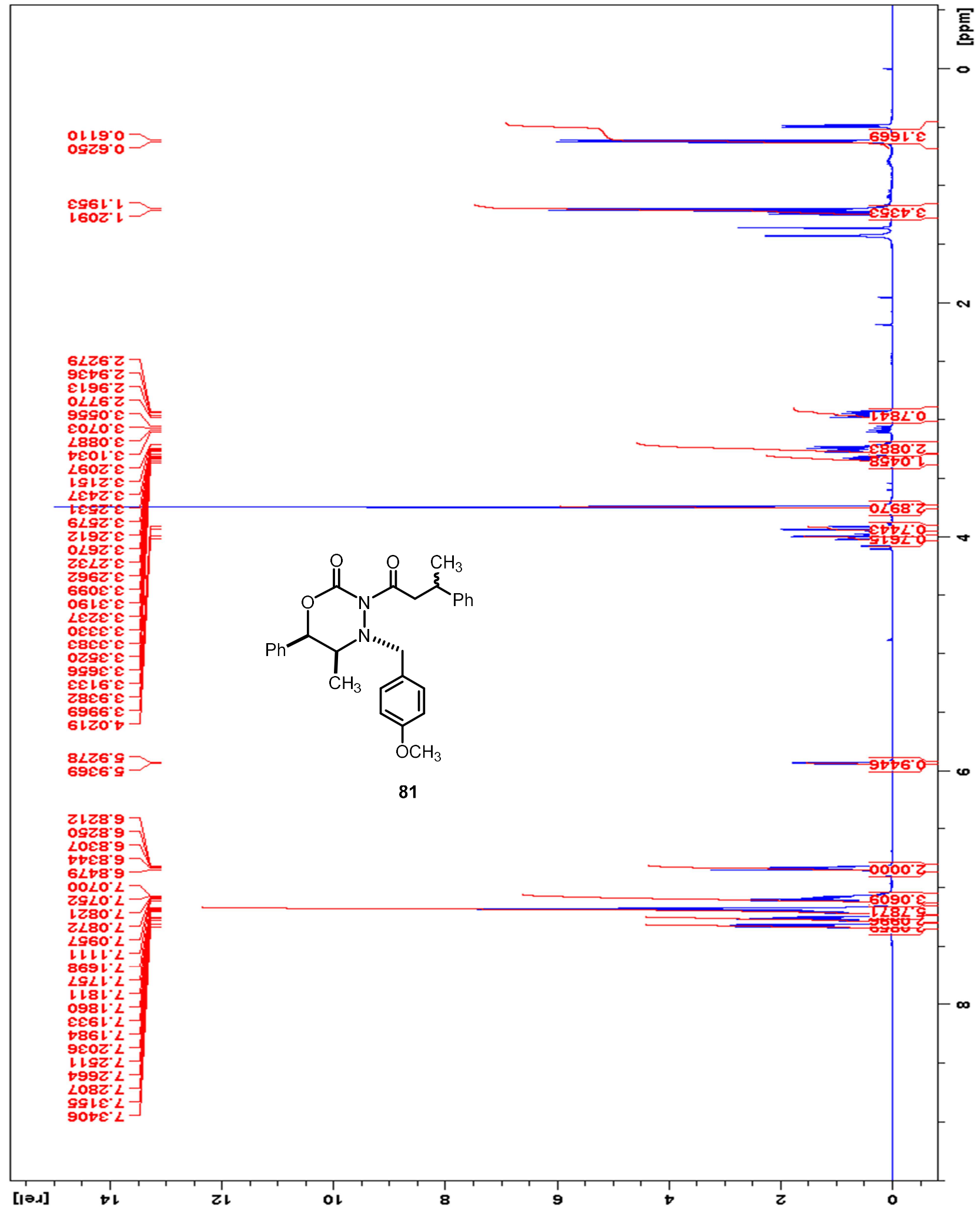


$100 \mathrm{MHz}{ }^{13} \mathrm{C}$ NMR spectrum of compound $\mathbf{8 1}$

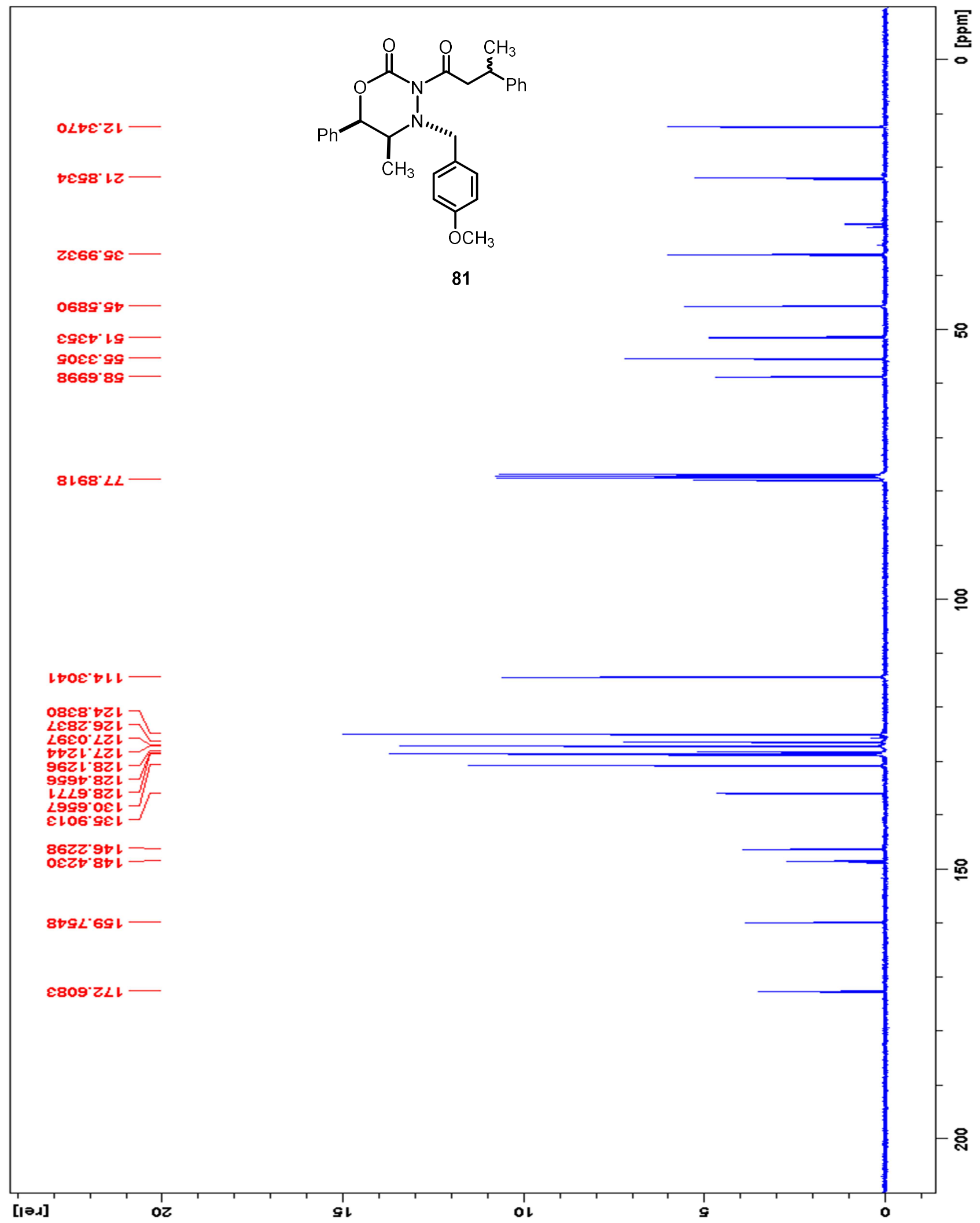


$500 \mathrm{MHz}{ }^{1} \mathrm{H}$ NMR spectrum of compound 80

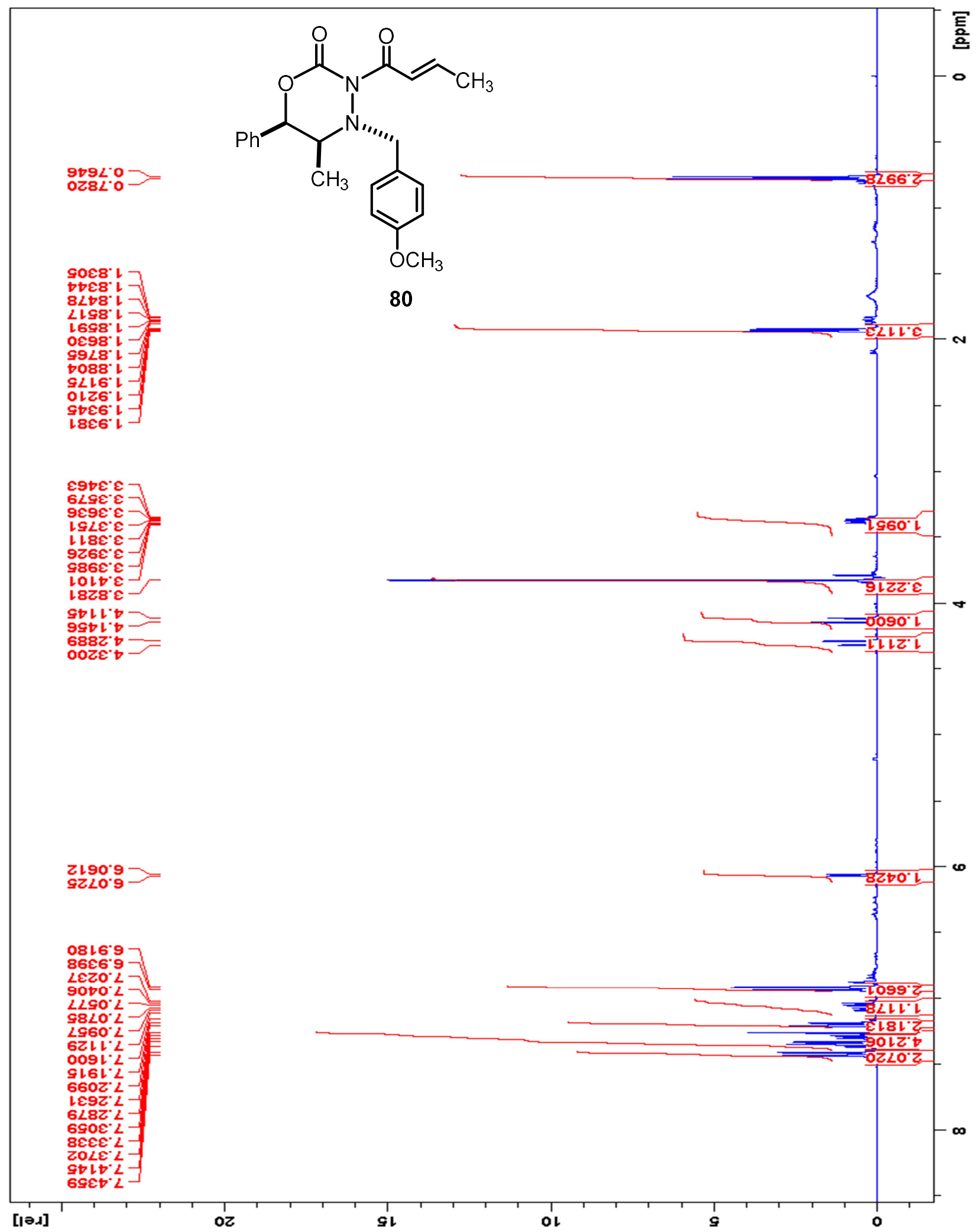


$100 \mathrm{MHz}{ }^{13} \mathrm{C}$ NMR spectrum of compound 80

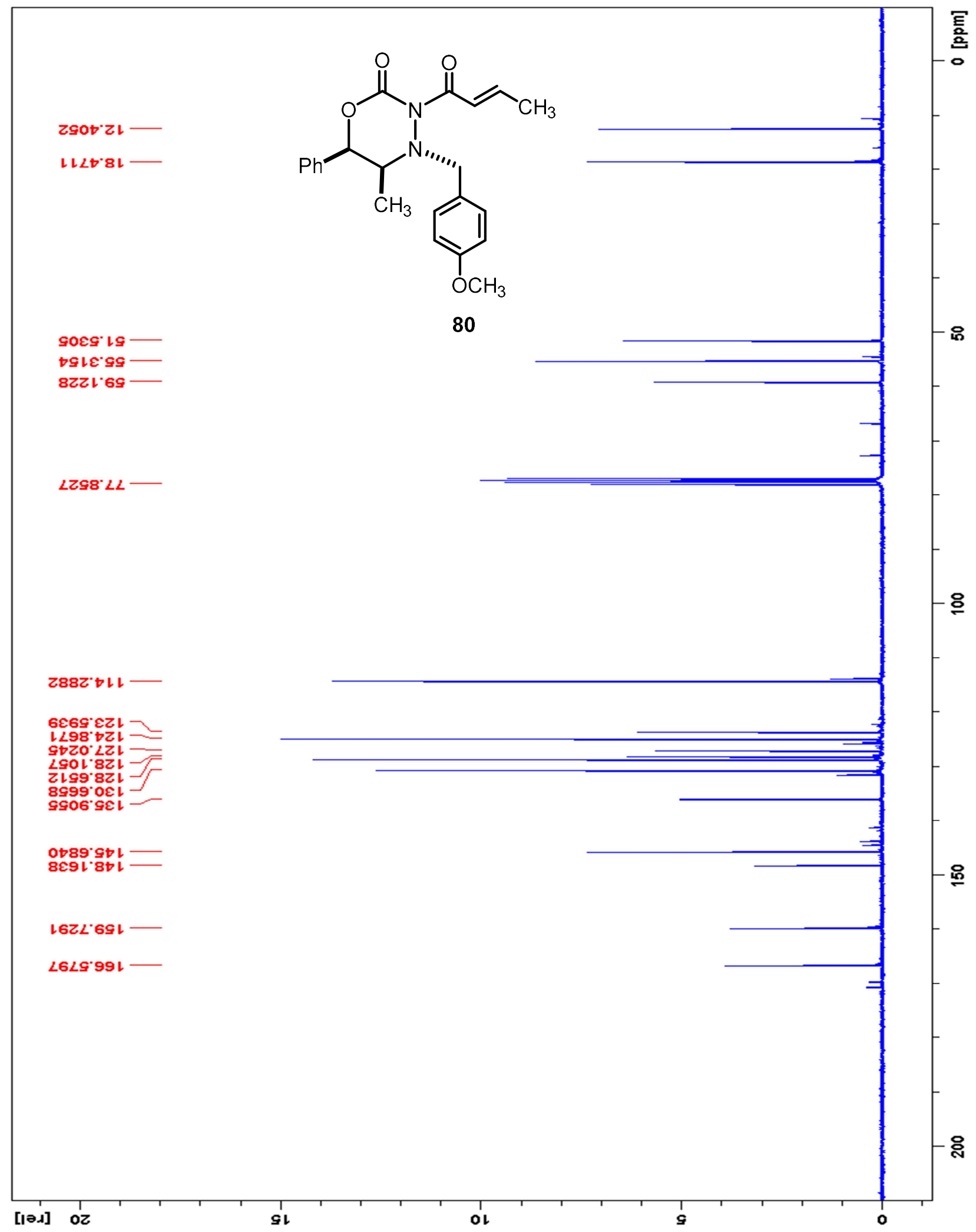


$500 \mathrm{MHz}{ }^{1} \mathrm{H}$ NMR spectrum of compound 82

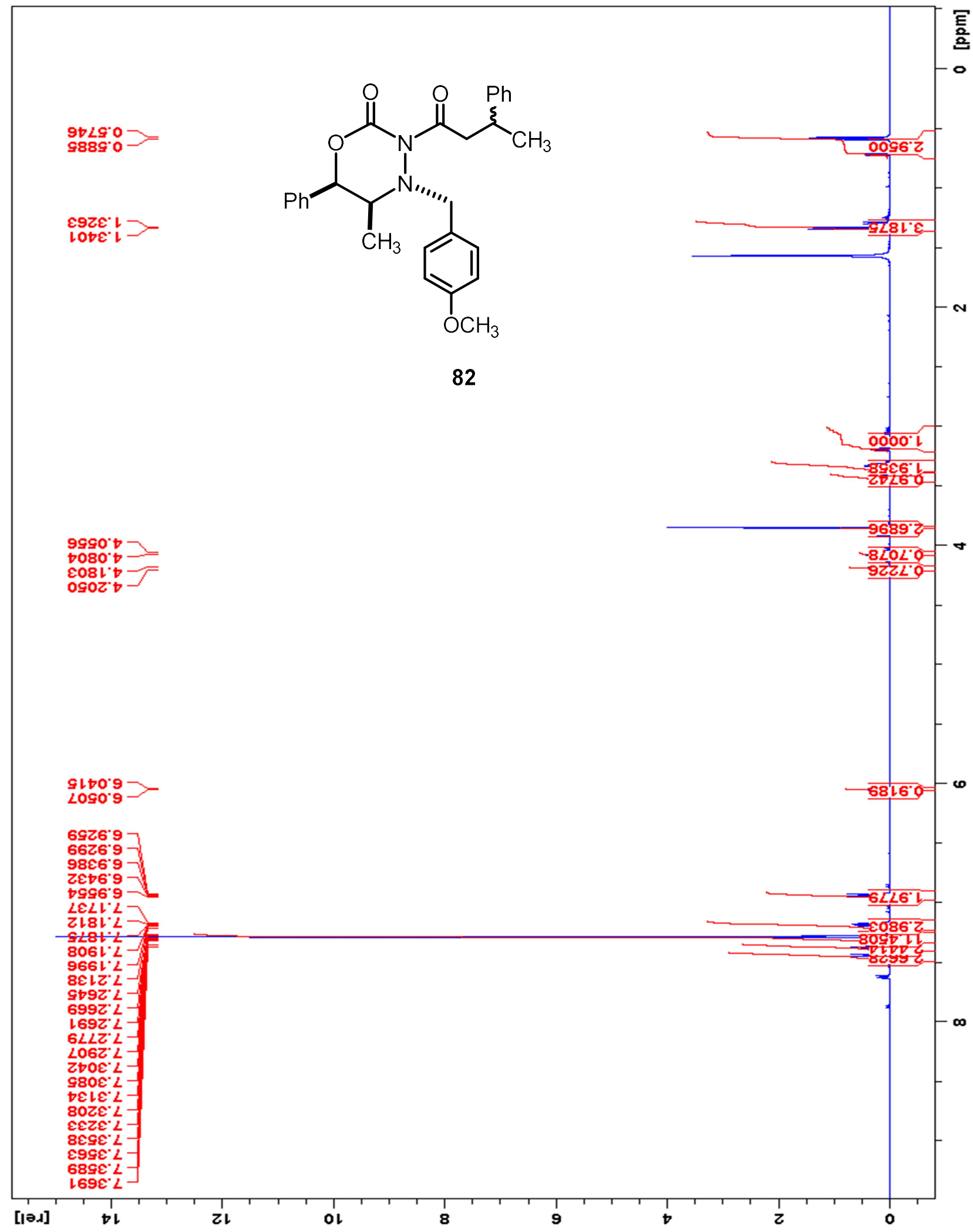


$100 \mathrm{MHz}{ }^{13} \mathrm{C}$ NMR spectrum of compound 82

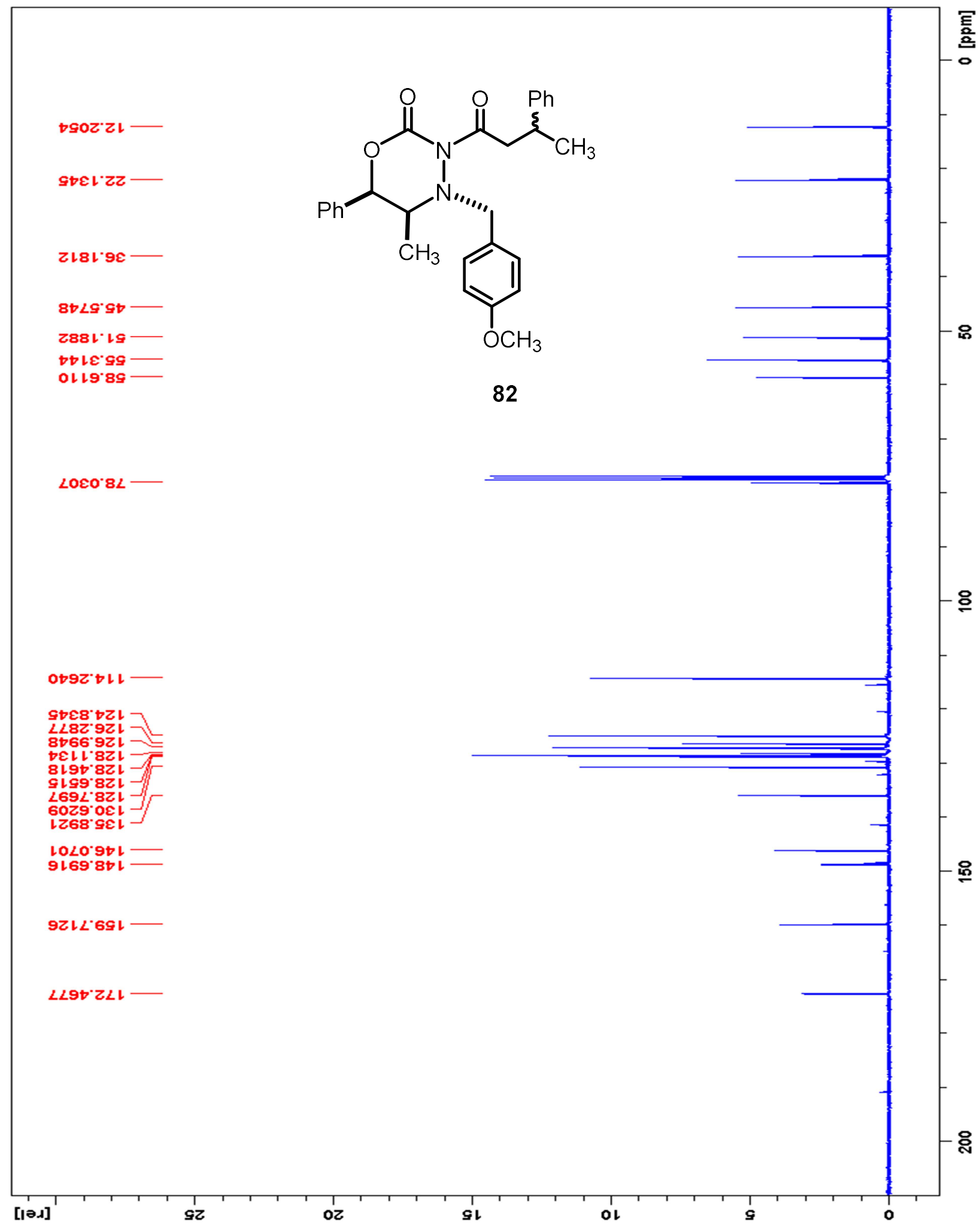


$500 \mathrm{MHz}{ }^{1} \mathrm{H}$ NMR spectrum of compound 84

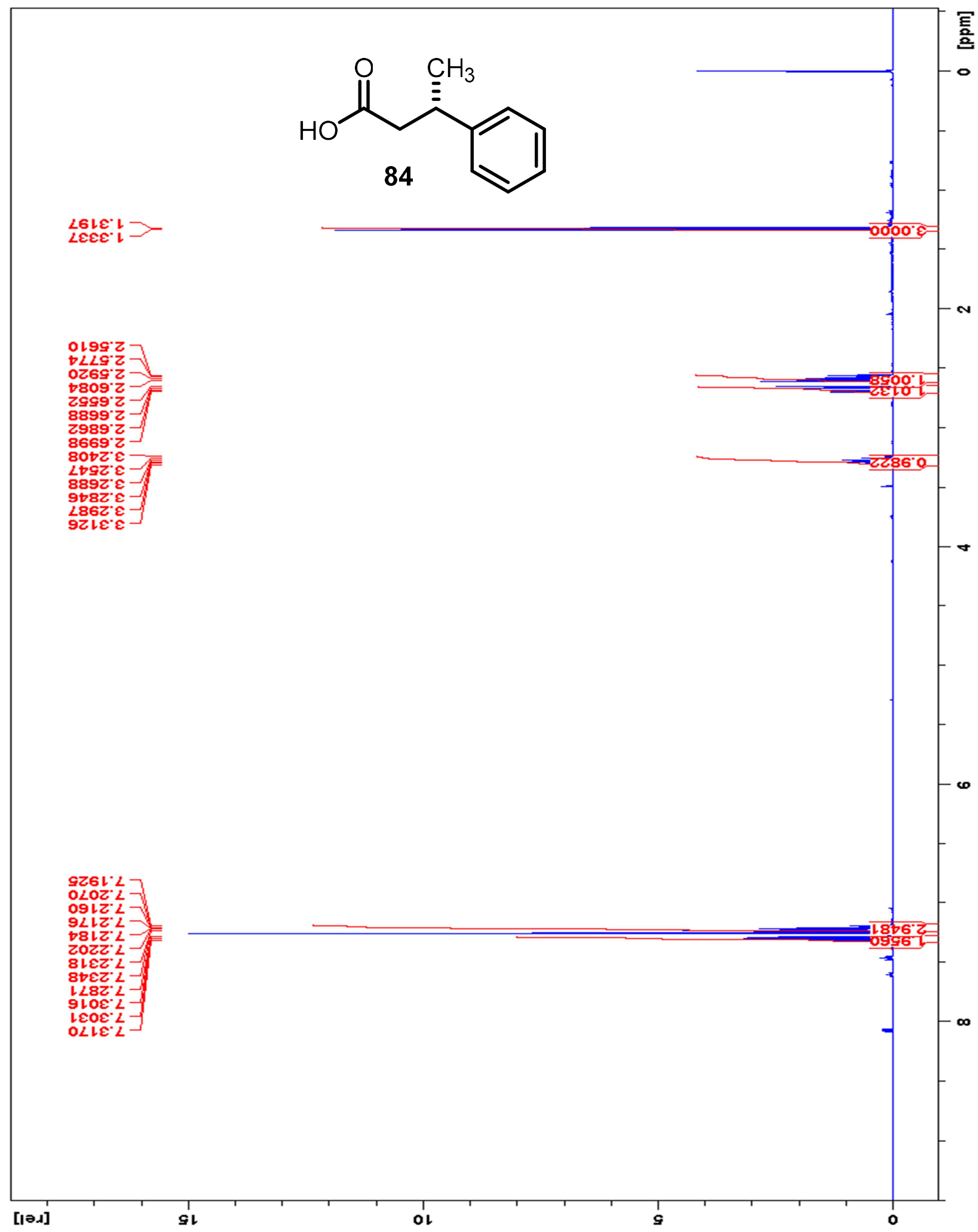


$100 \mathrm{MHz}{ }^{13} \mathrm{C}$ NMR spectrum of compound 84

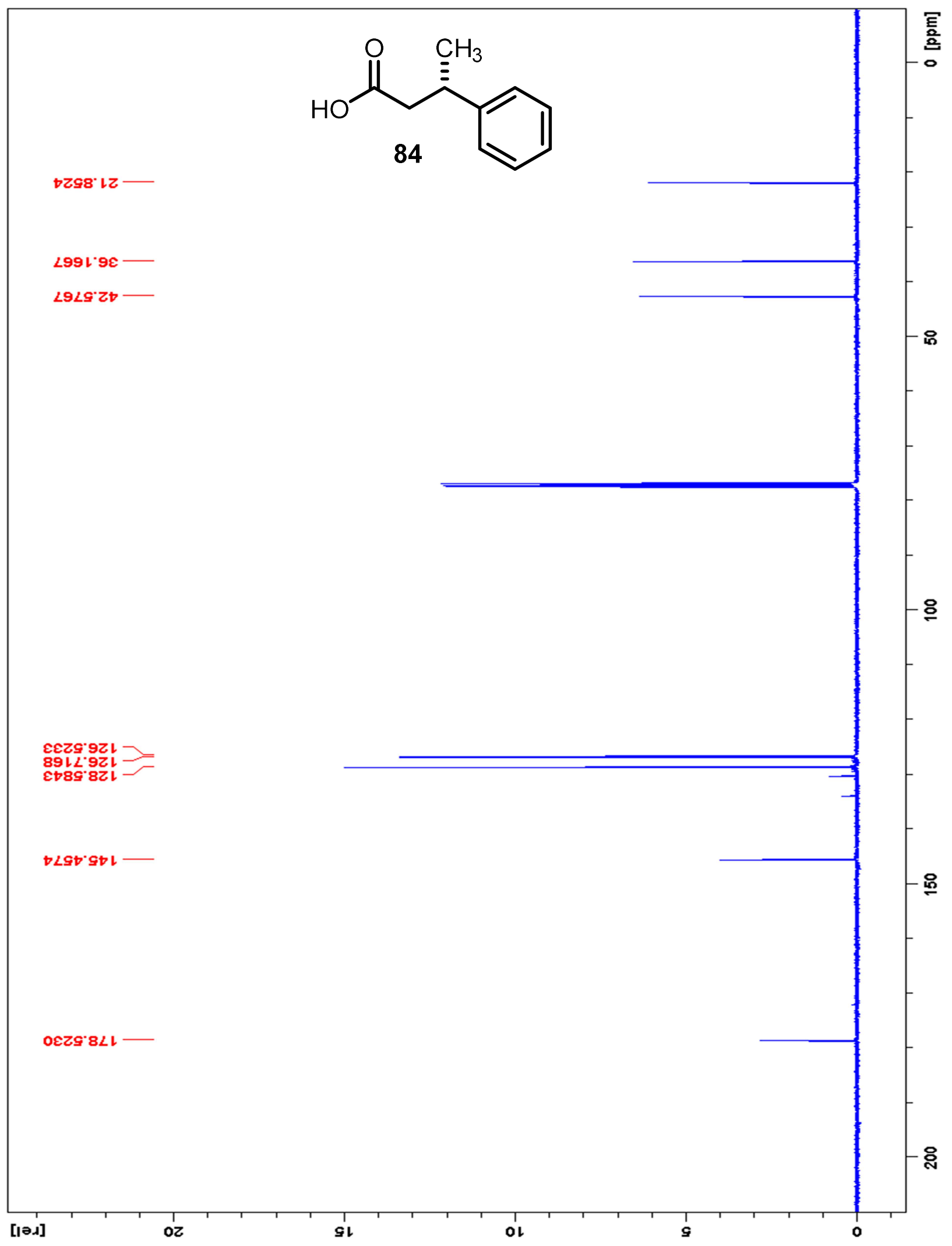


$500 \mathrm{MHz}{ }^{1} \mathrm{H}$ NMR spectrum of compound 86

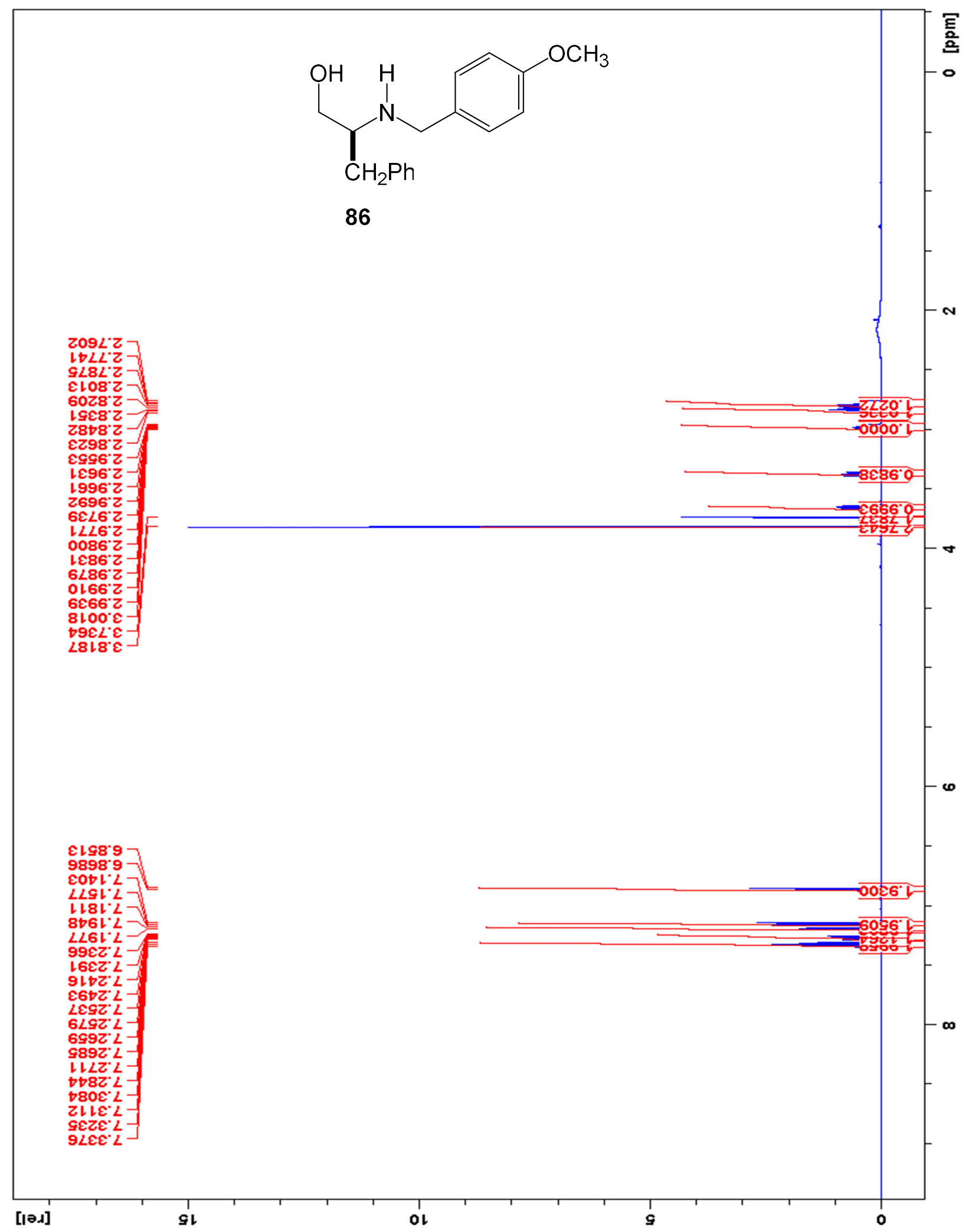


$125 \mathrm{MHz}{ }^{13} \mathrm{C}$ NMR spectrum of compound 86

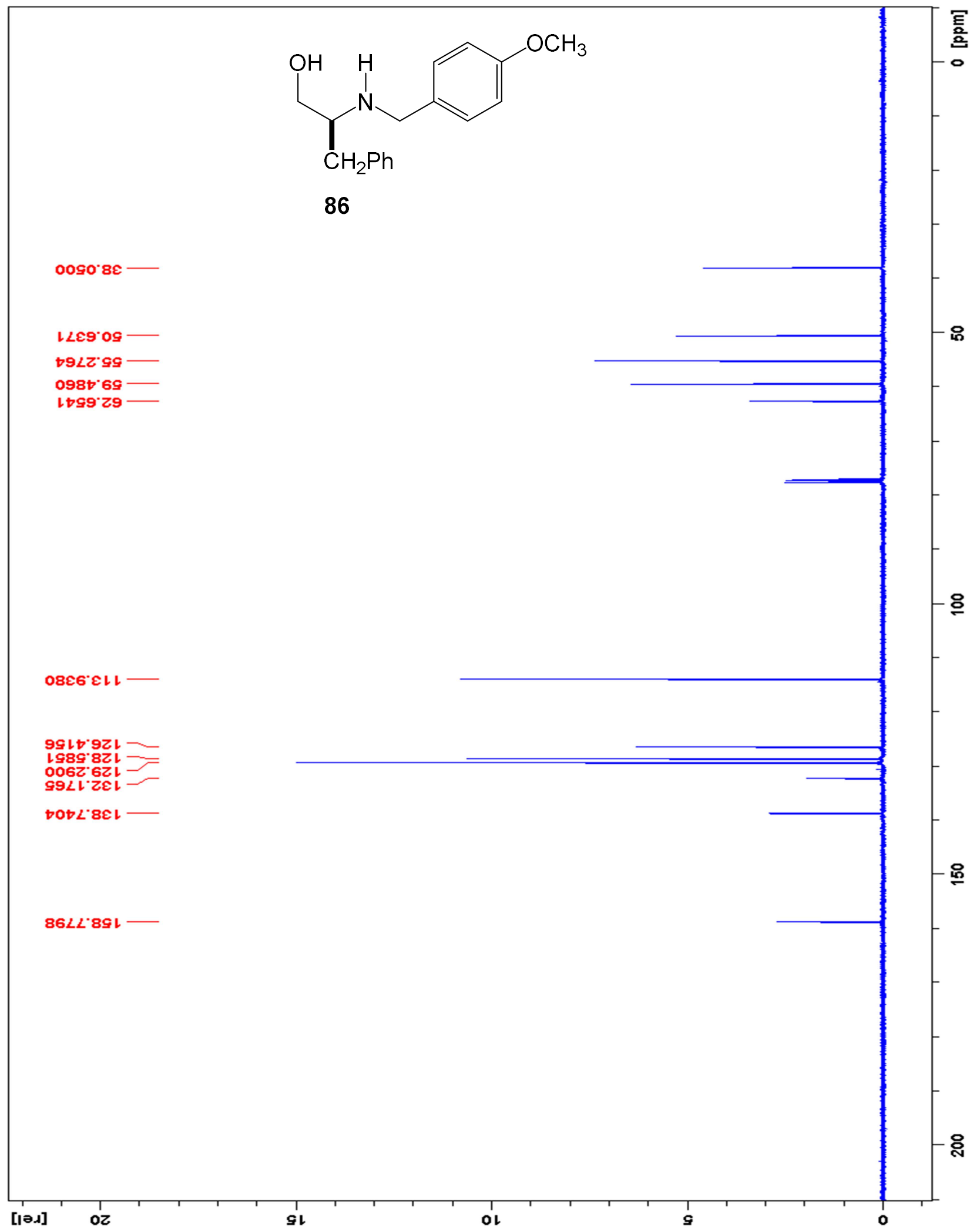


$500 \mathrm{MHz}{ }^{1} \mathrm{H}$ NMR spectrum of compound 87

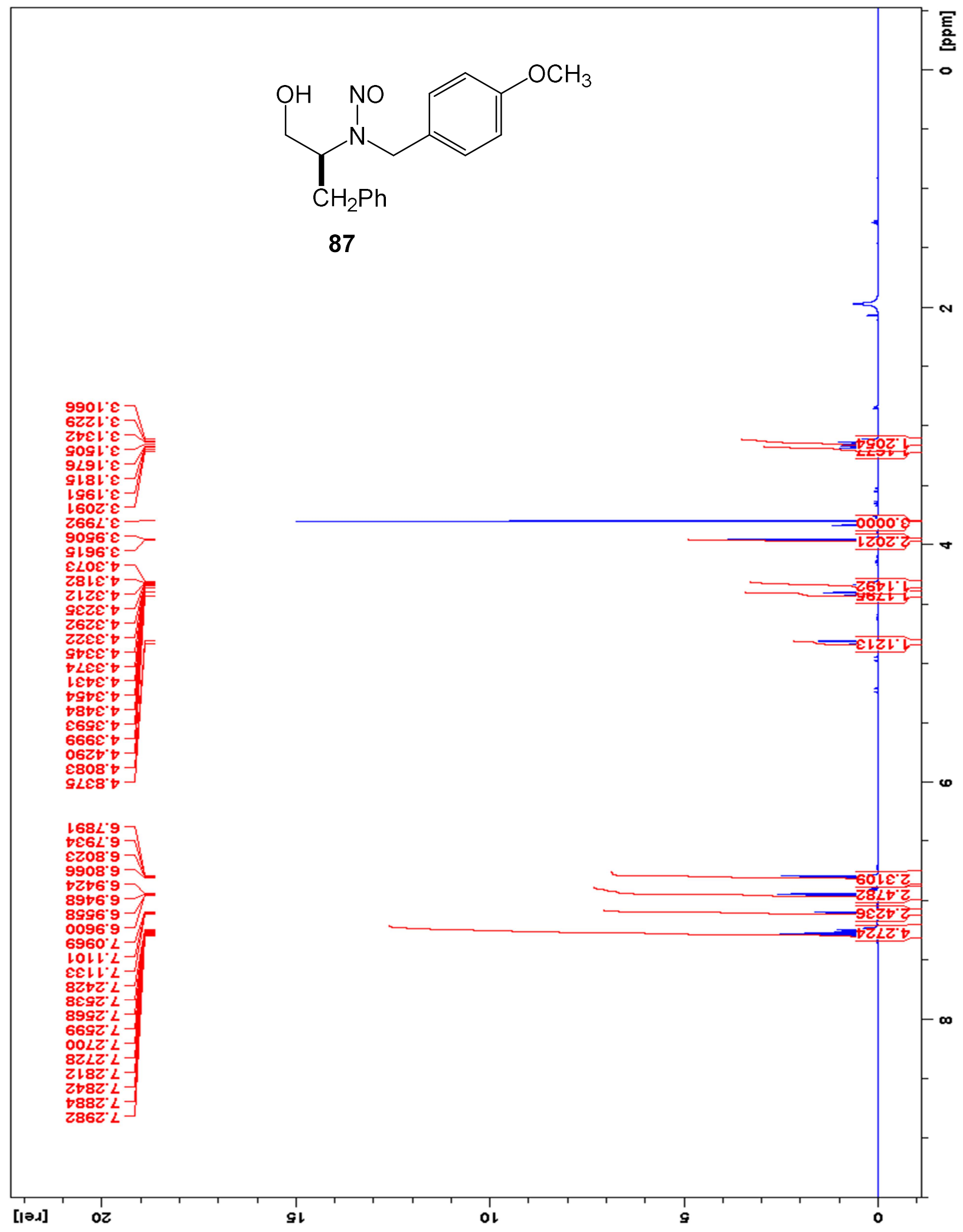


$100 \mathrm{MHz}{ }^{13} \mathrm{C}$ NMR spectrum of compound 87

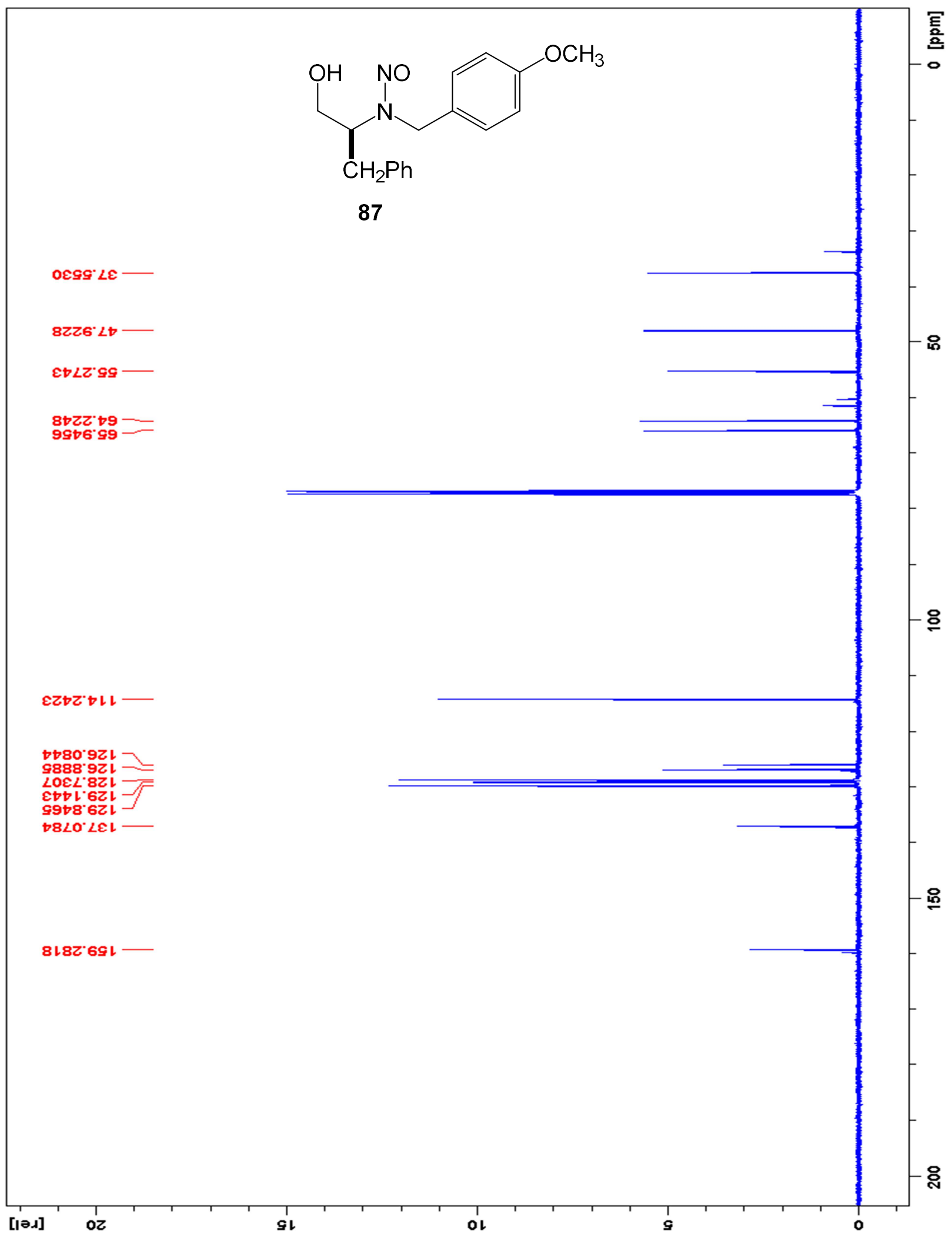


$500 \mathrm{MHz}{ }^{1} \mathrm{H}$ NMR spectrum of compound 89

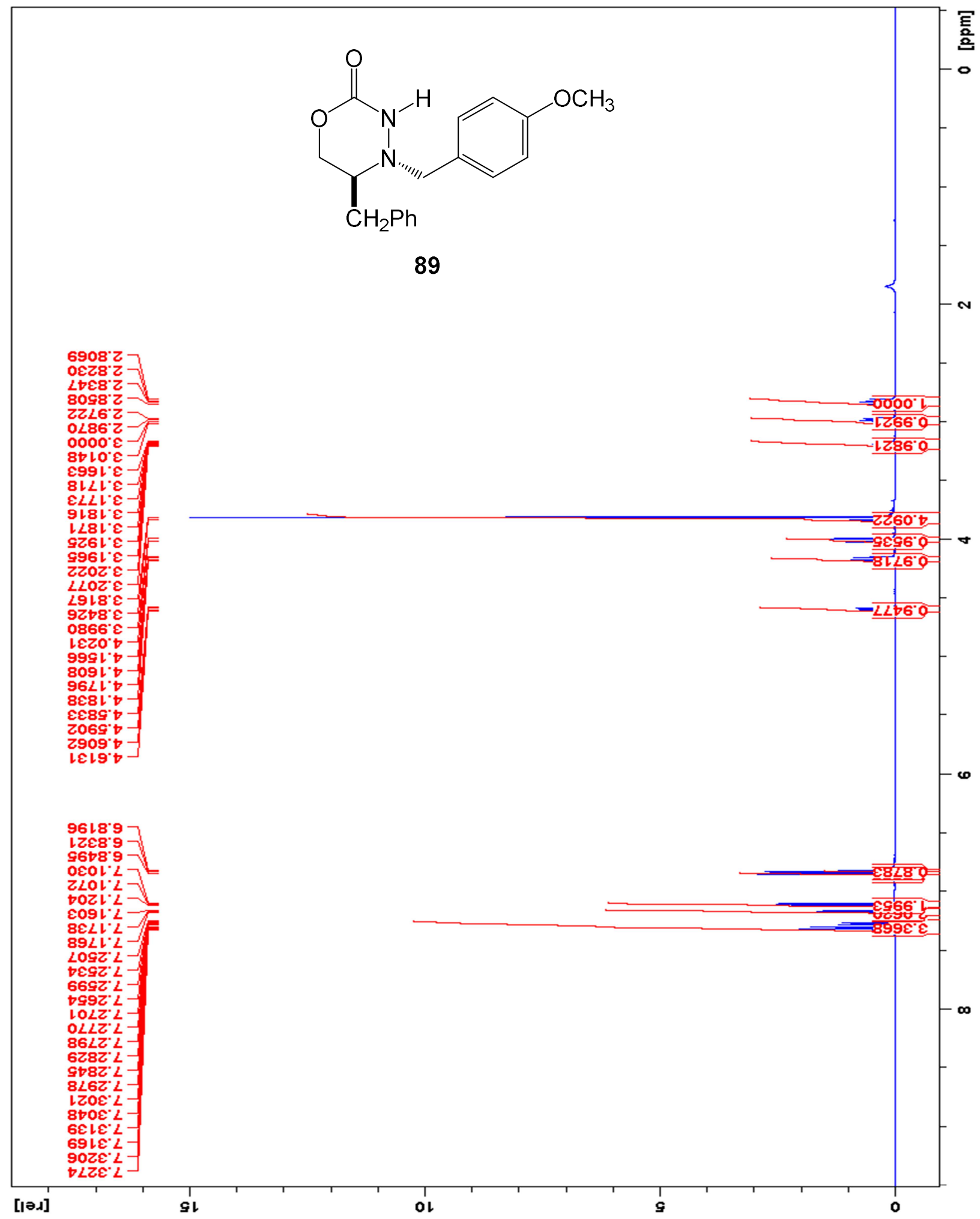


$100 \mathrm{MHz}{ }^{13} \mathrm{C}$ NMR spectrum of compound 89

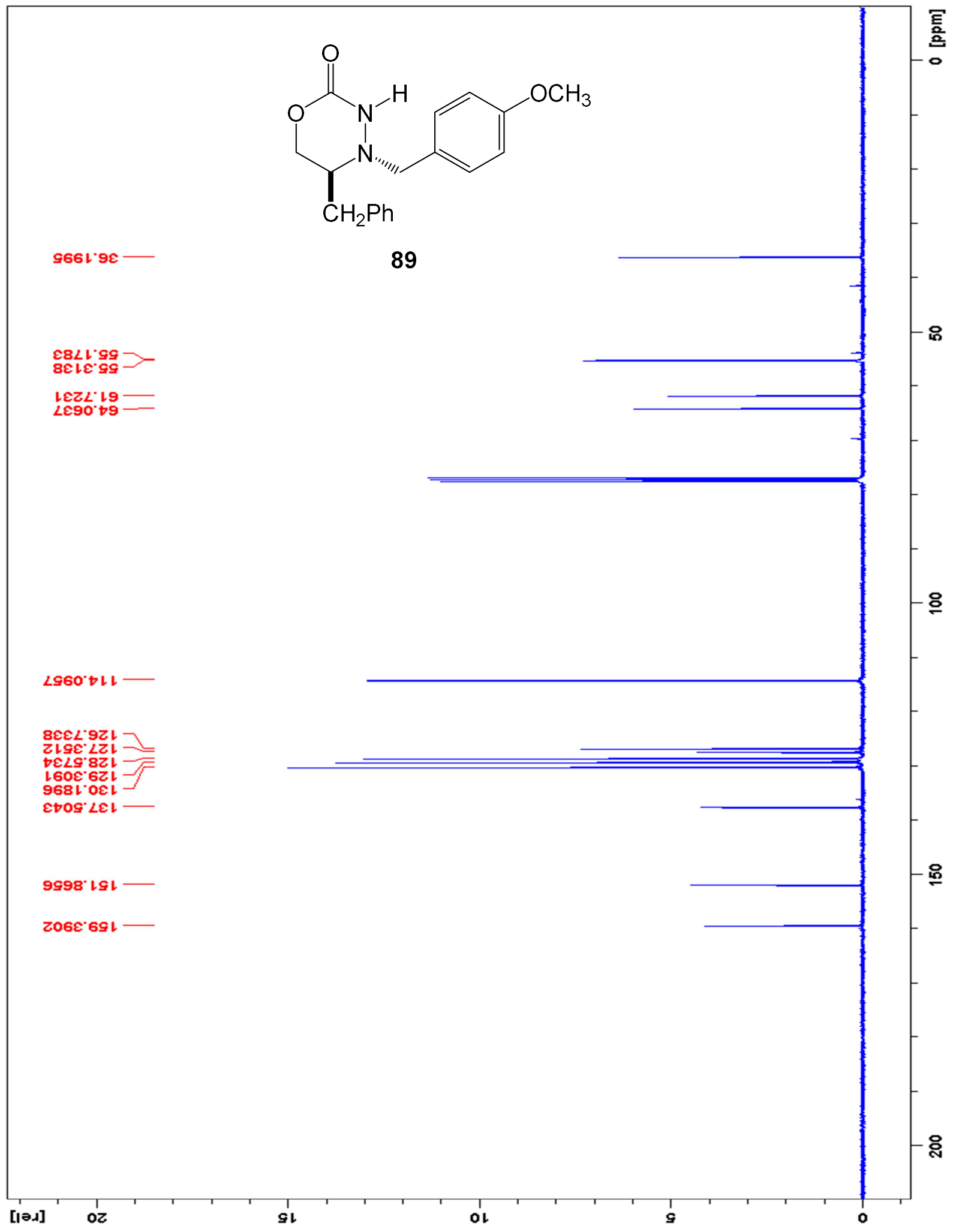


$500 \mathrm{MHz}{ }^{1} \mathrm{H}$ NMR spectrum of compound 90

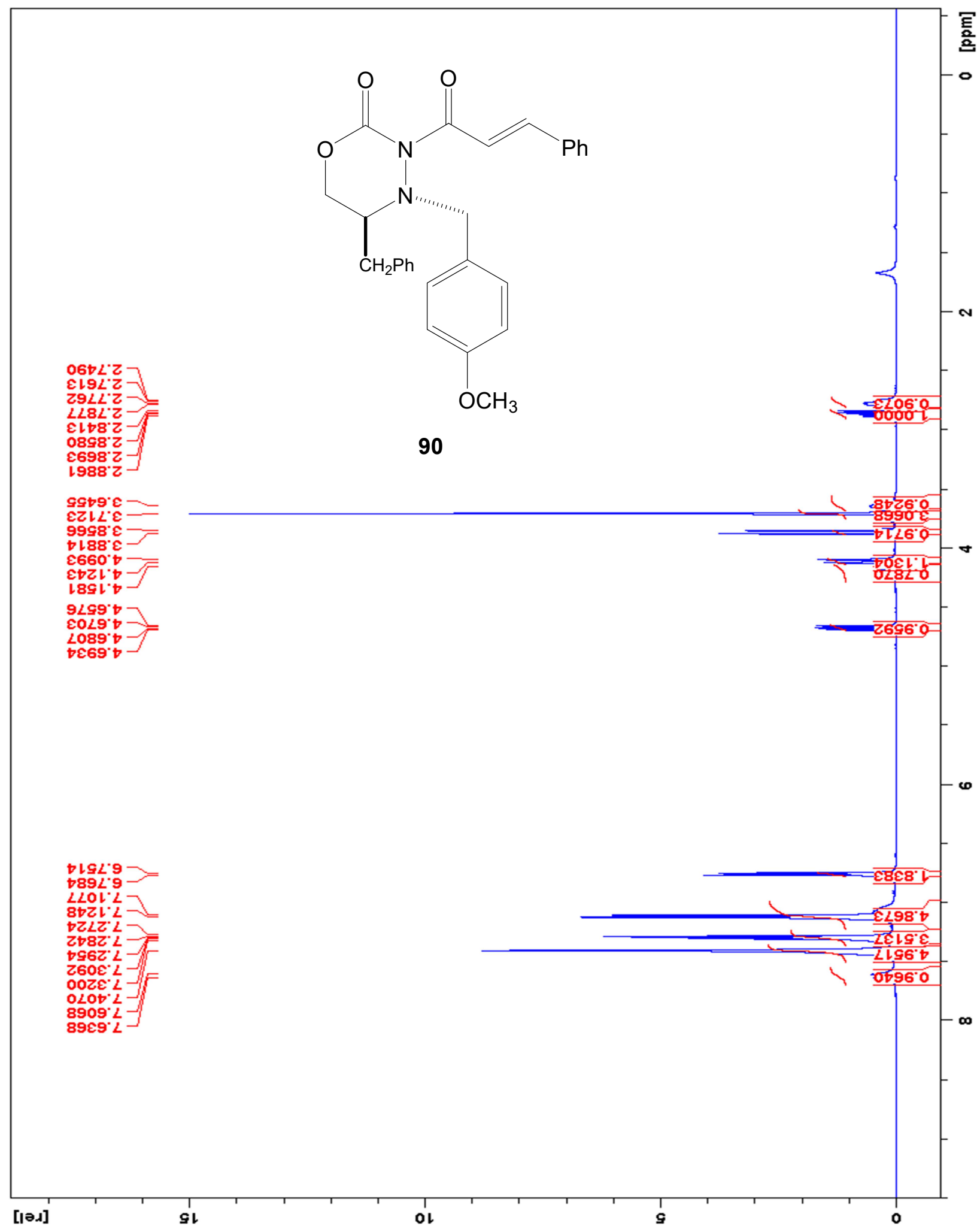


$125 \mathrm{MHz}{ }^{13} \mathrm{C}$ NMR spectrum of compound 90 with line broadening

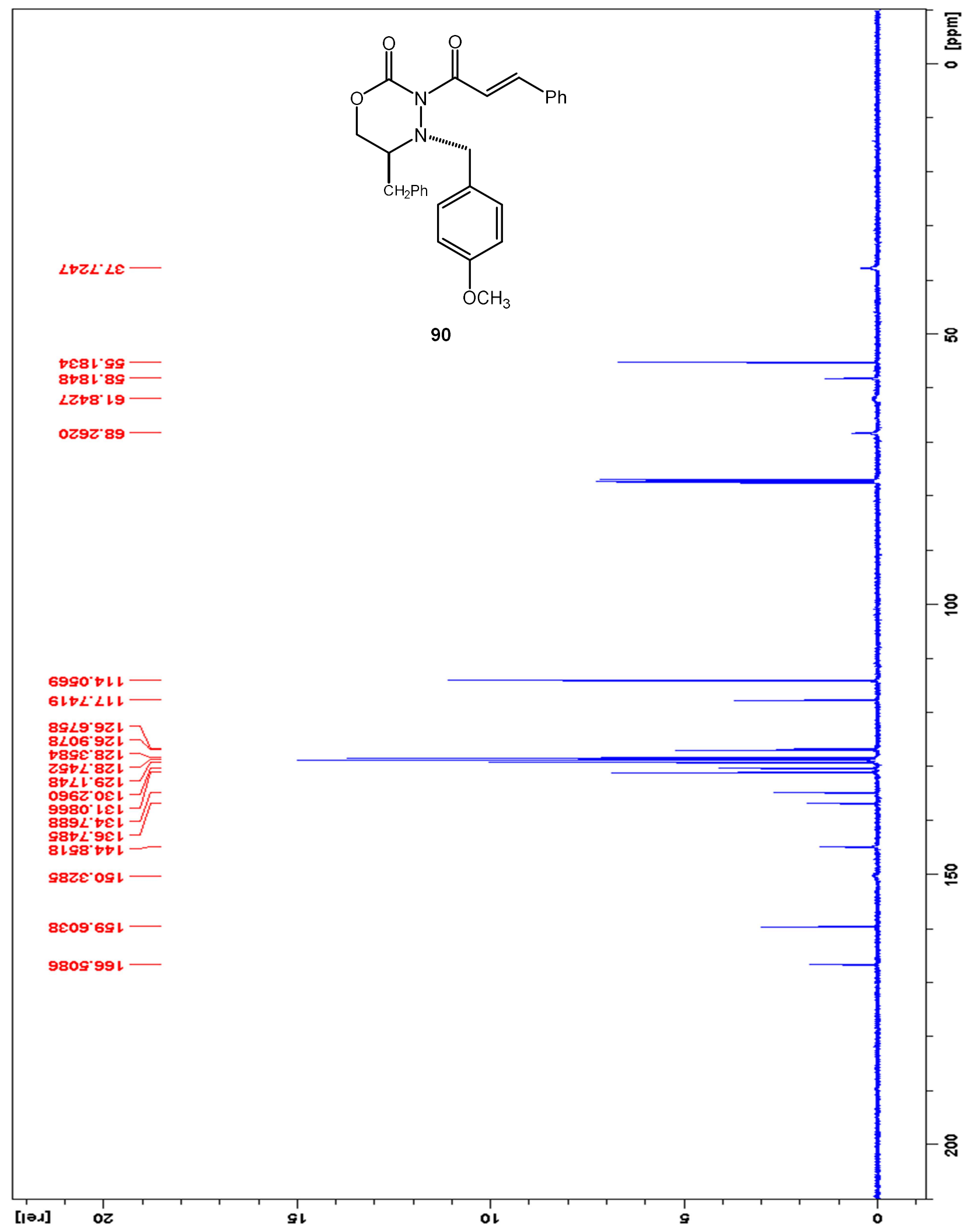


$500 \mathrm{MHz}{ }^{1} \mathrm{H}$ NMR spectrum of compound $\mathbf{9 4 c}$

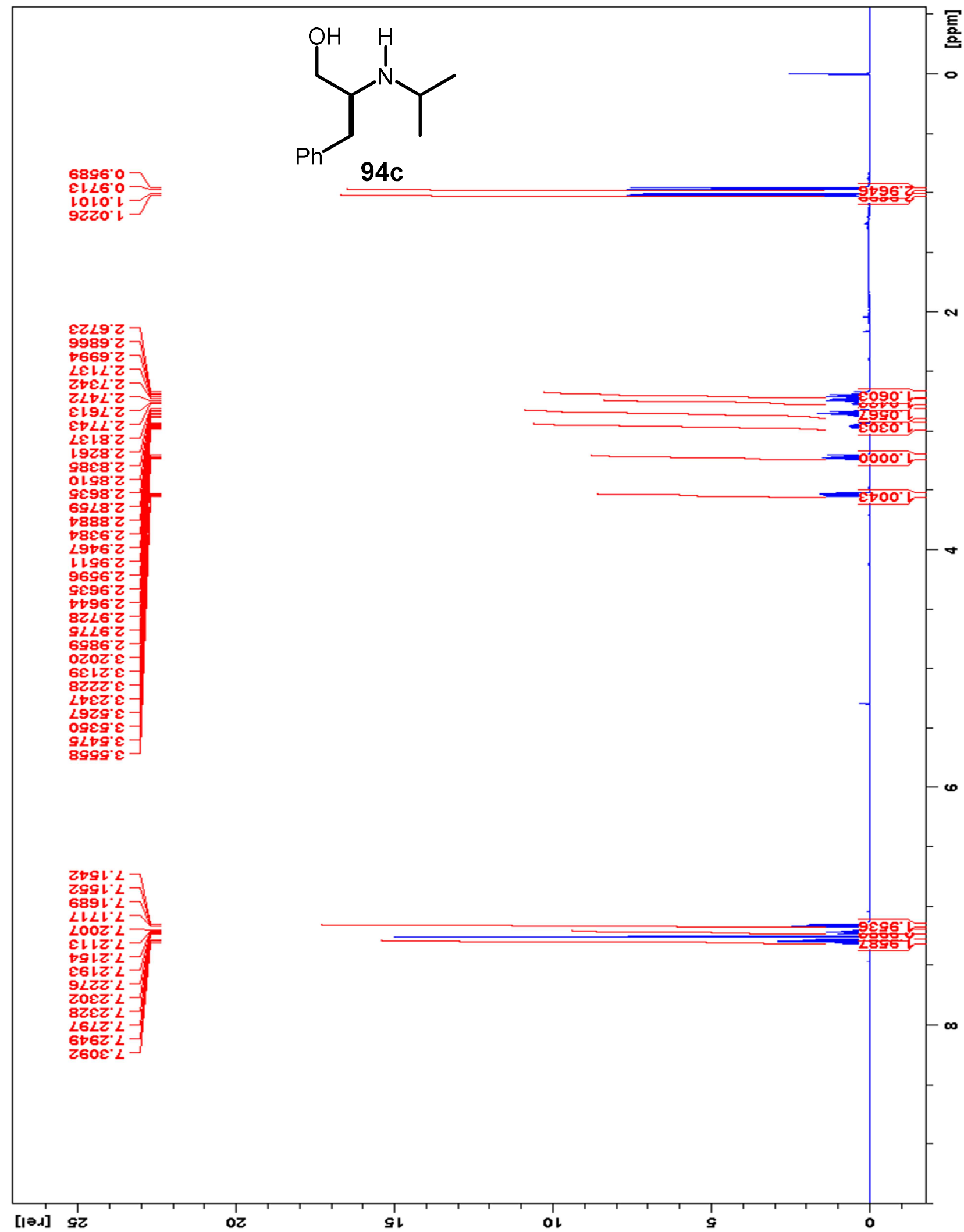


$125 \mathrm{MHz}{ }^{13} \mathrm{C}$ NMR spectrum of compound $\mathbf{9 4 c}$

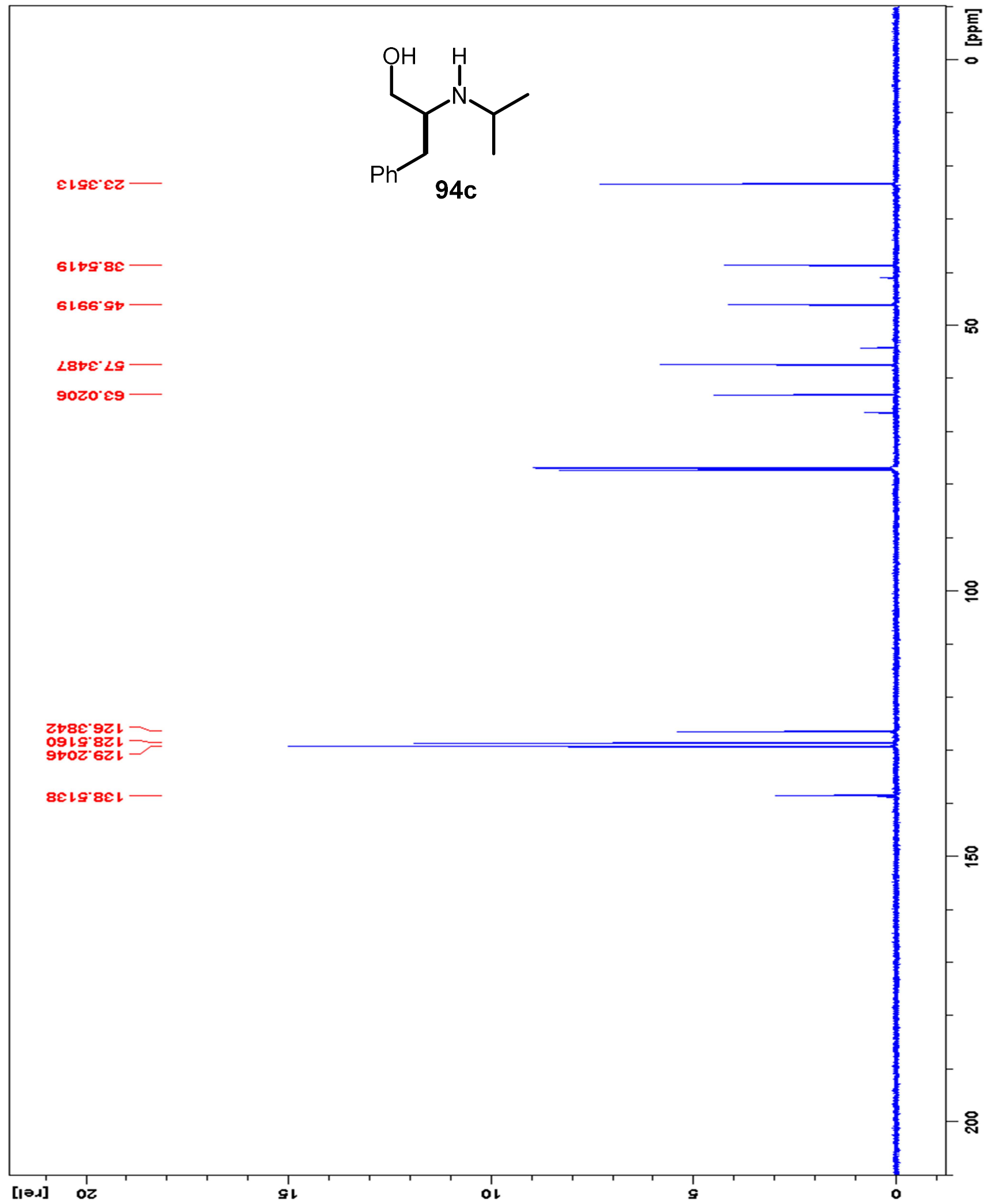


$500 \mathrm{MHz}{ }^{1} \mathrm{H}$ NMR spectrum of compound 94d

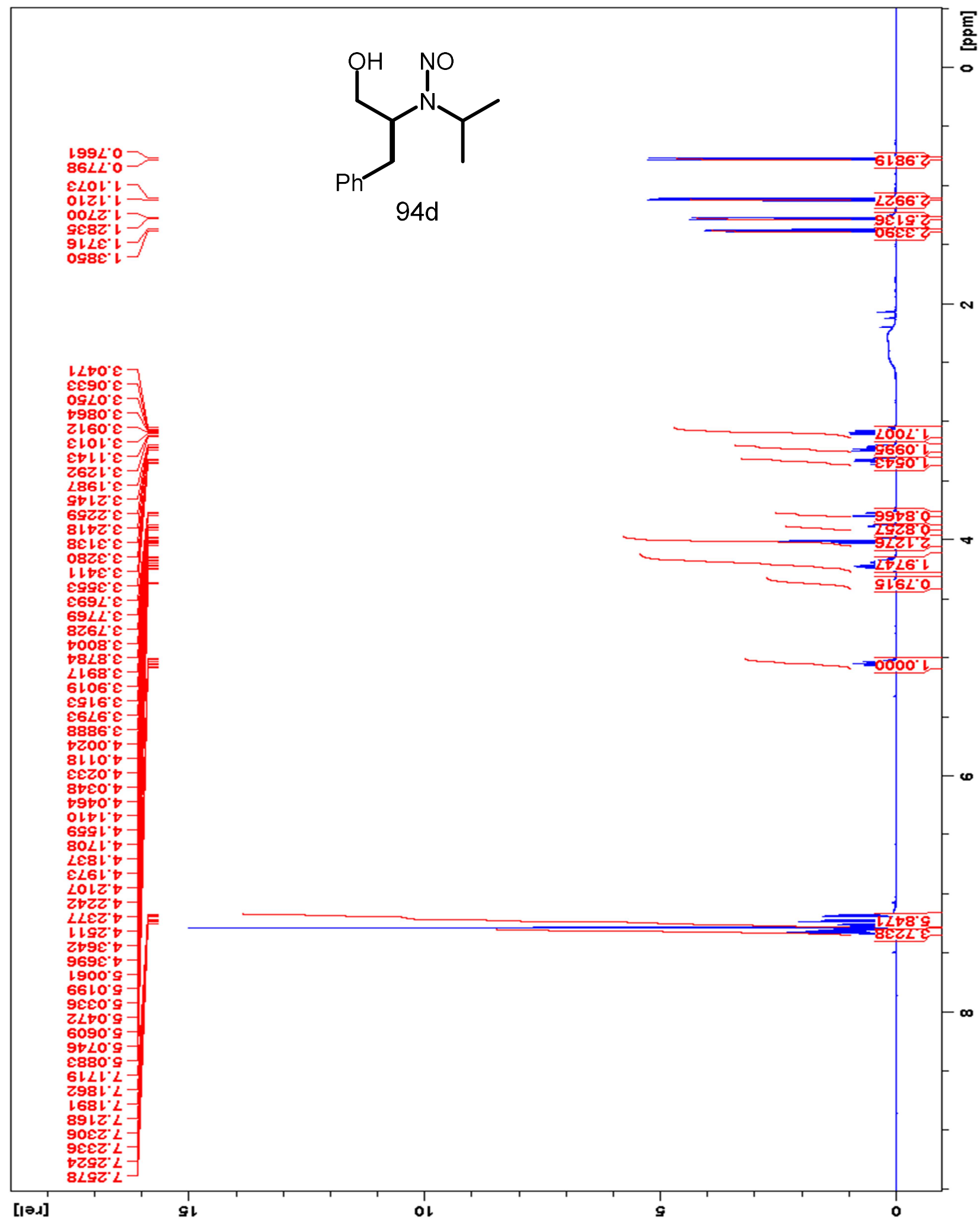


$500 \mathrm{MHz}{ }^{1} \mathrm{H}$ NMR spectrum of compound 95

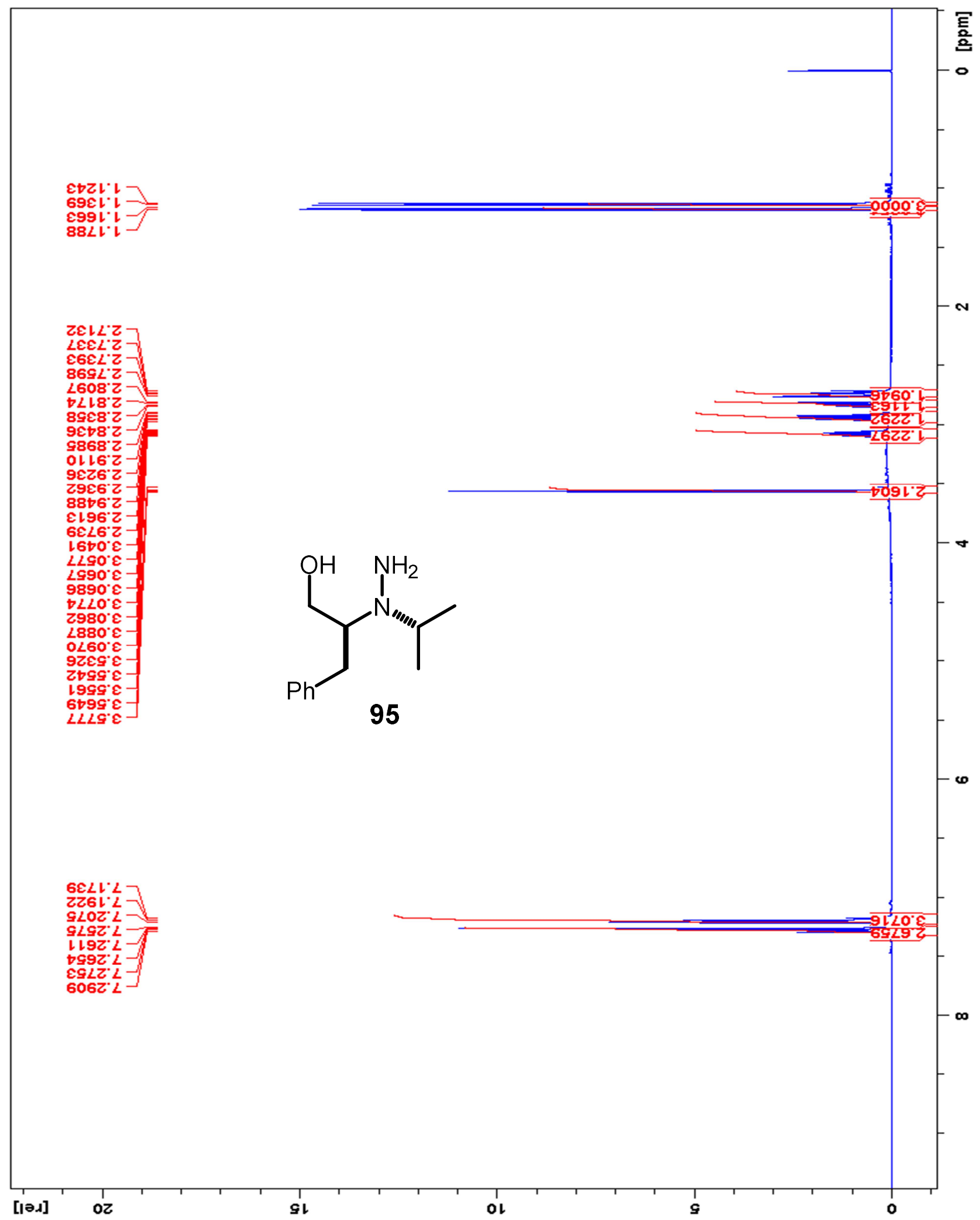


$100 \mathrm{MHz}{ }^{13} \mathrm{C}$ NMR spectrum of compound 95

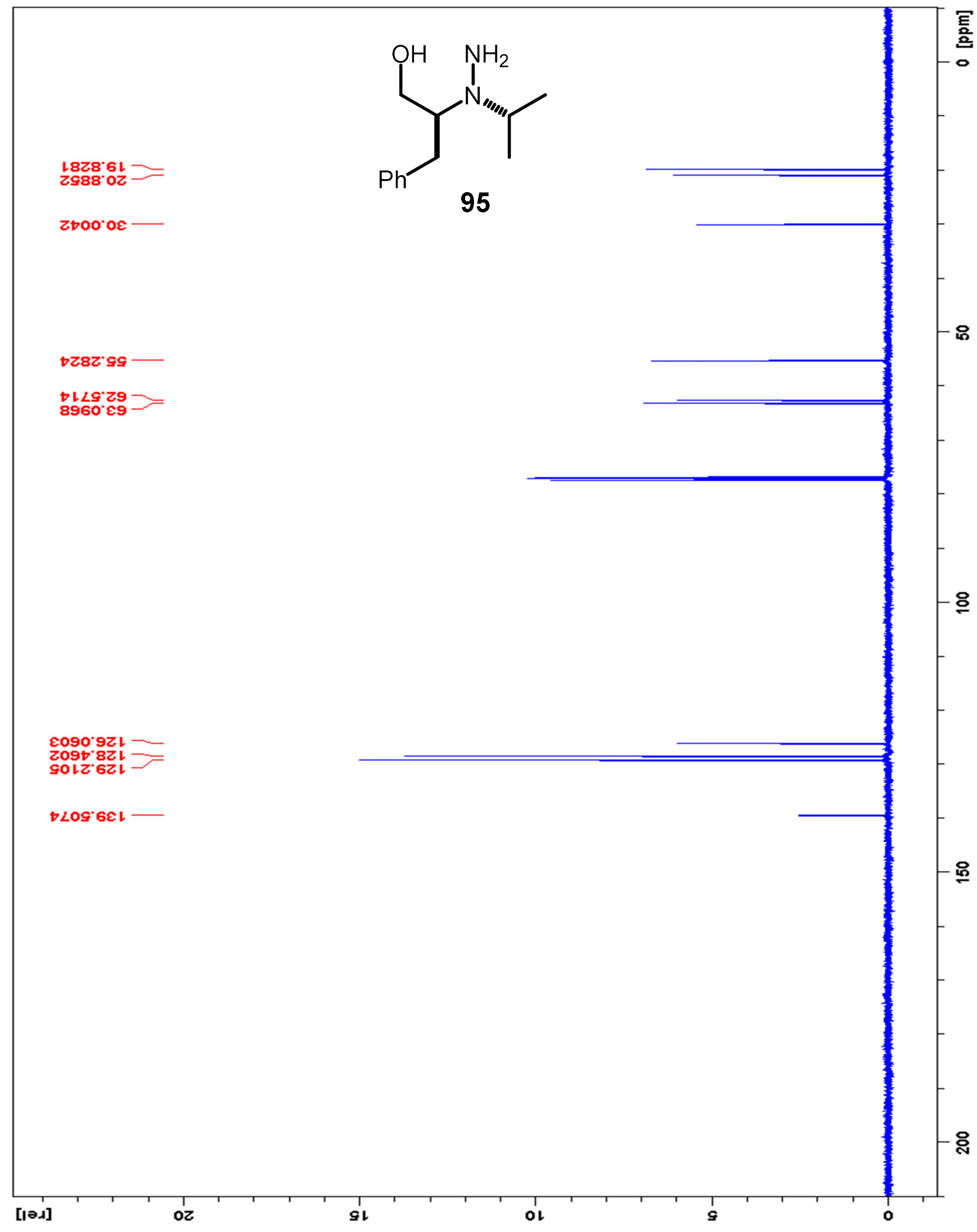


$500 \mathrm{MHz}{ }^{1} \mathrm{H}$ NMR spectrum of compound 94

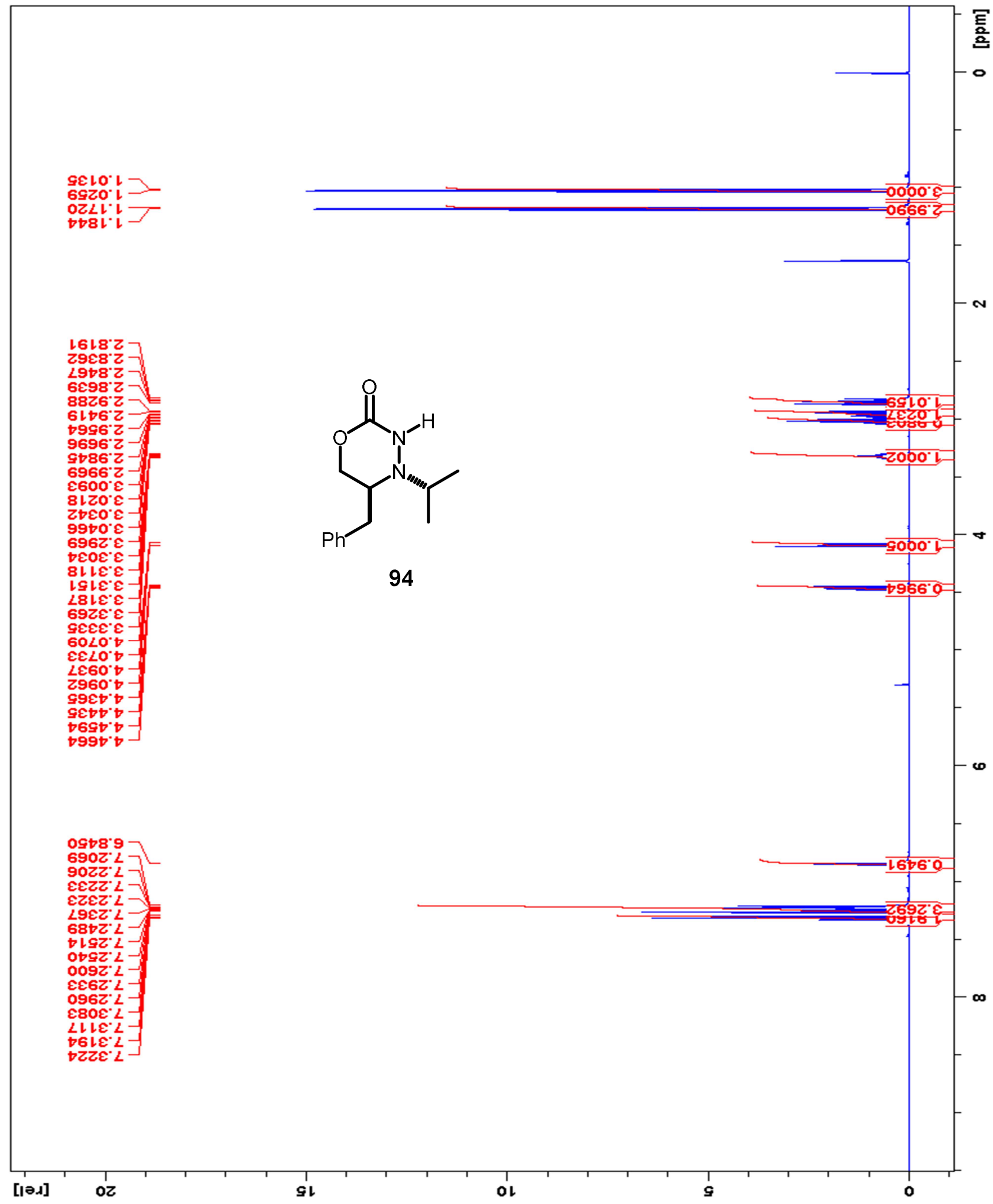


$125 \mathrm{MHz}{ }^{13} \mathrm{C}$ NMR spectrum of compound 94

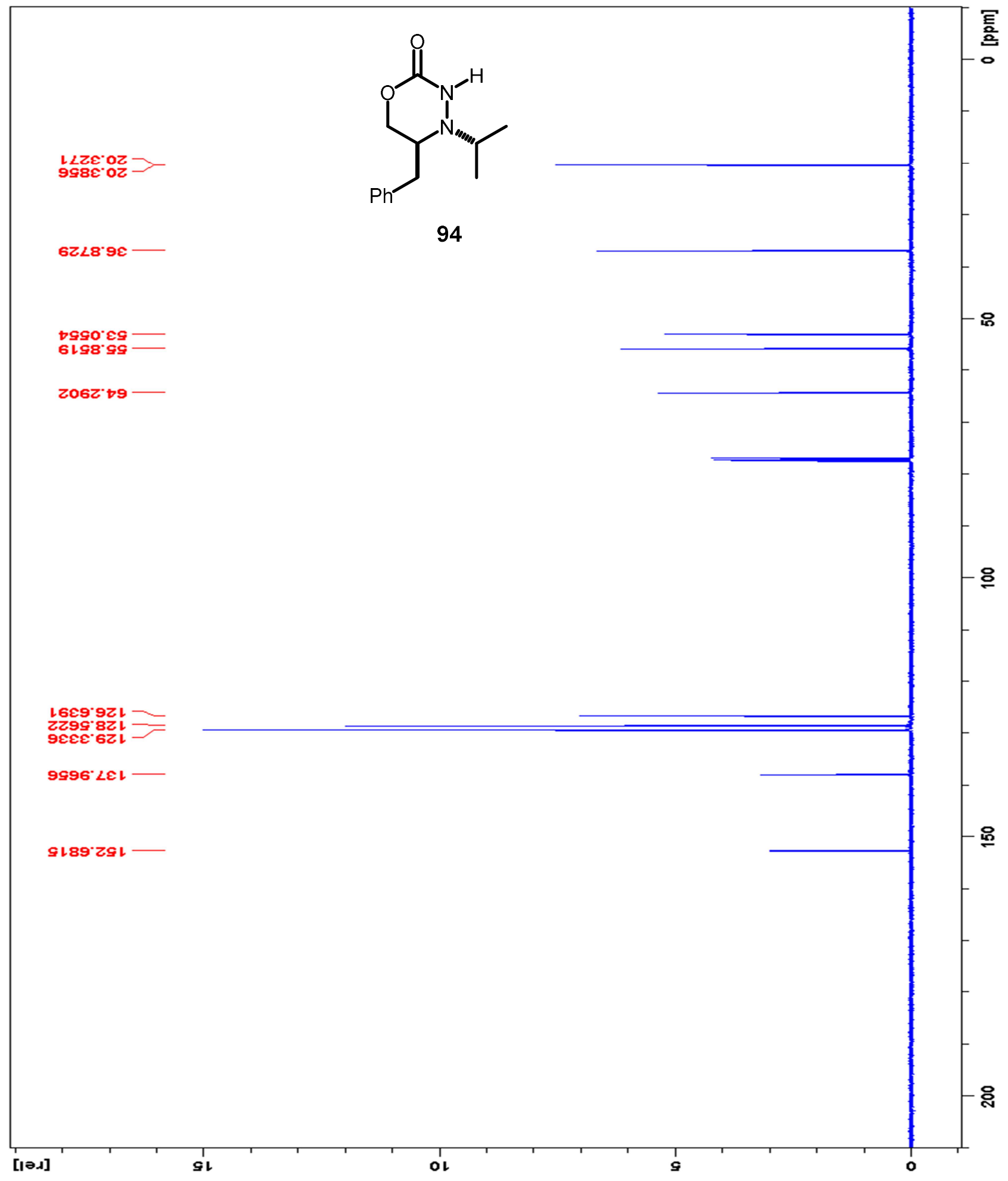


$500 \mathrm{MHz}{ }^{1} \mathrm{H}$ NMR spectrum of compound 97

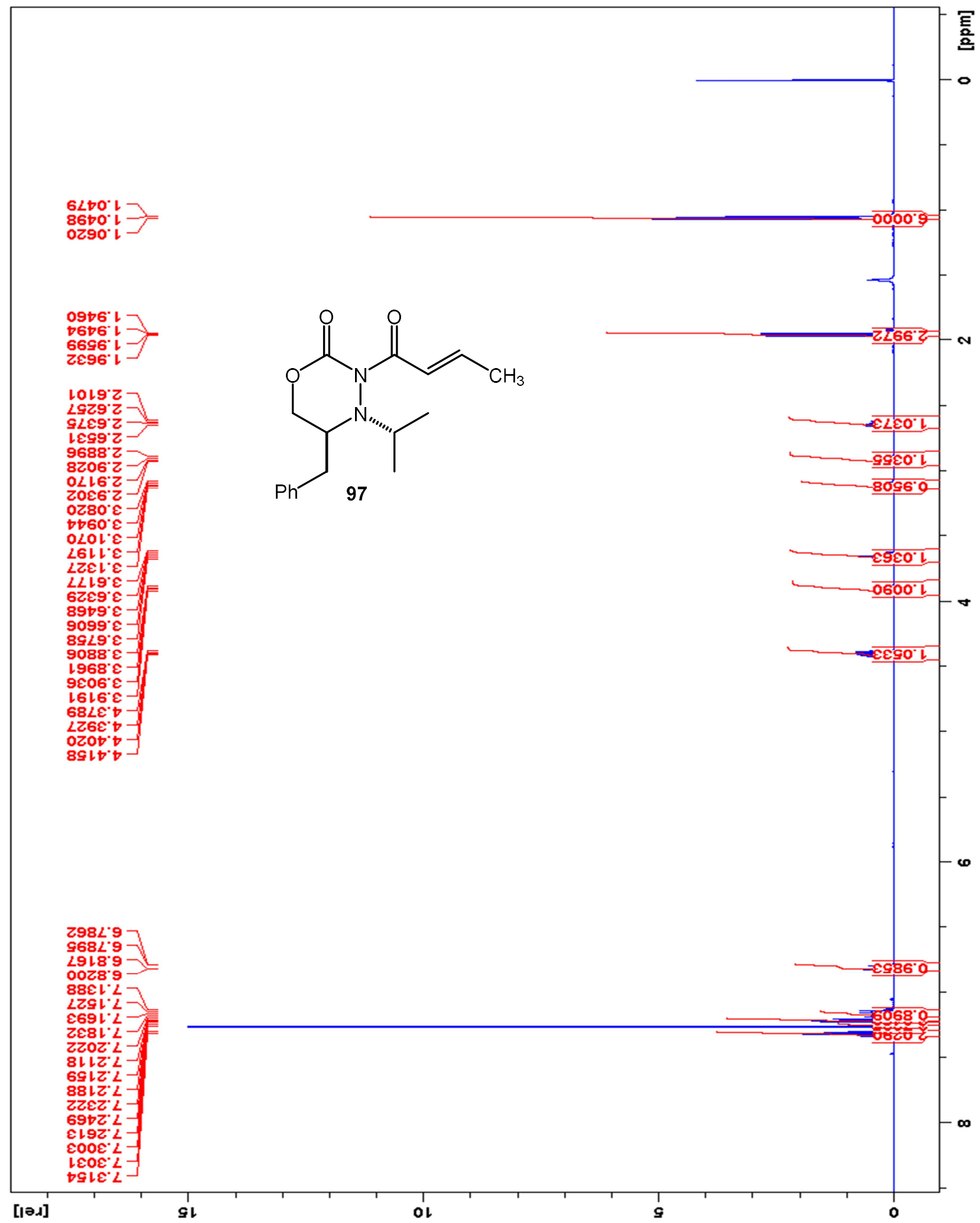


$500 \mathrm{MHz}{ }^{1} \mathrm{H}$ NMR spectrum of compound 98

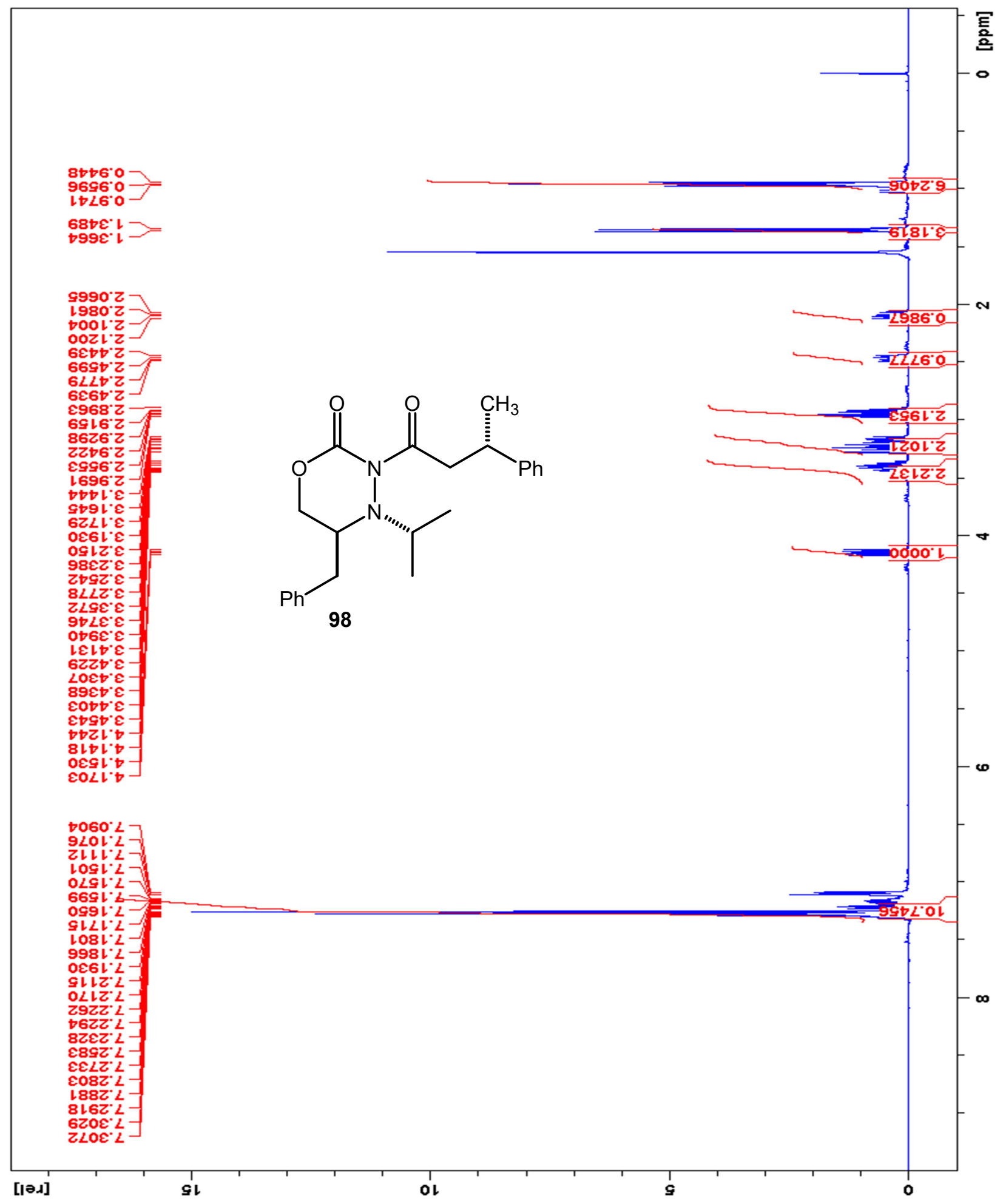


$100 \mathrm{MHz}{ }^{13} \mathrm{C}$ NMR spectrum of compound 98

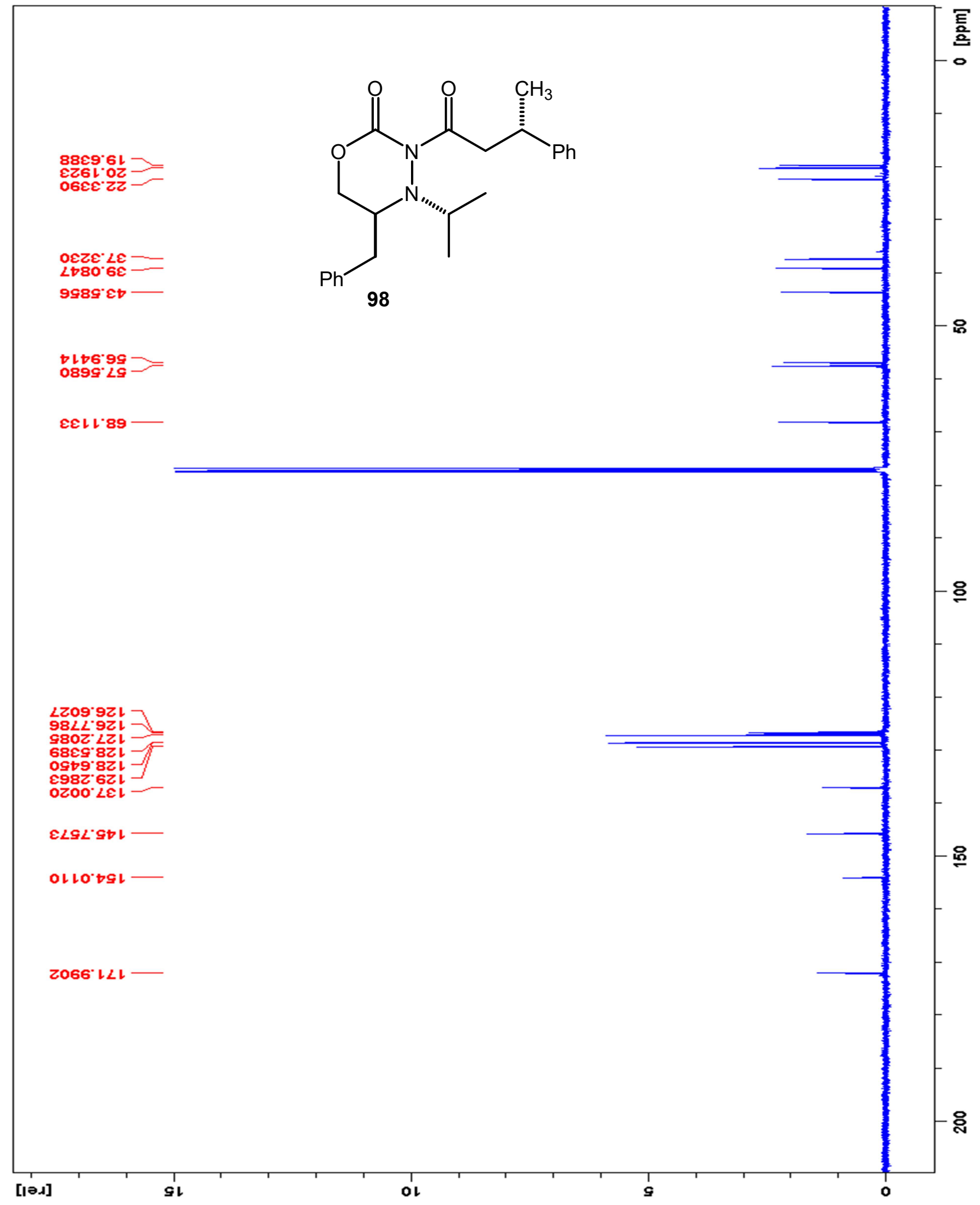


$500 \mathrm{MHz}{ }^{1} \mathrm{H}$ NMR spectrum of compound 99

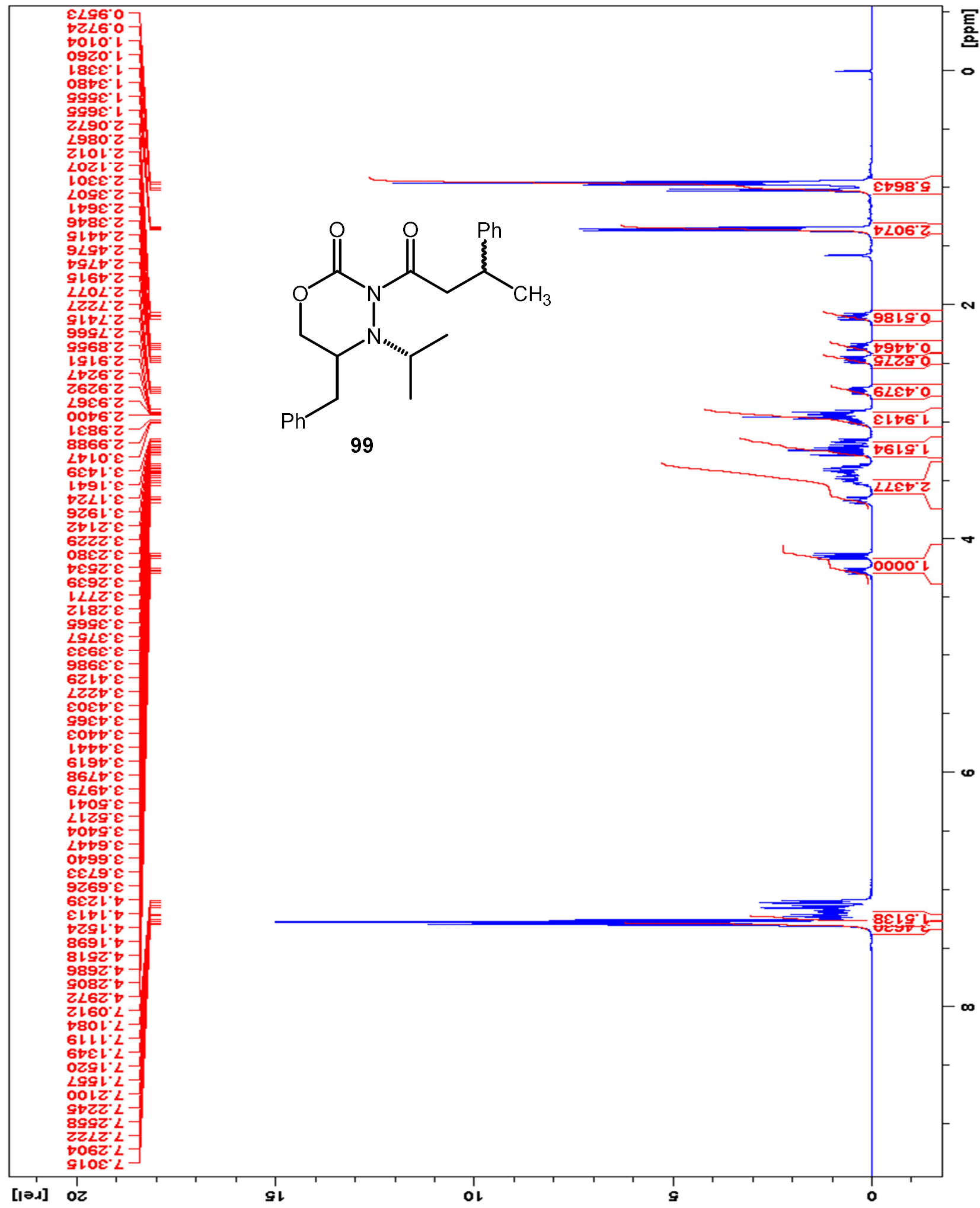


$100 \mathrm{MHz}{ }^{13} \mathrm{C}$ NMR spectrum of compound 99

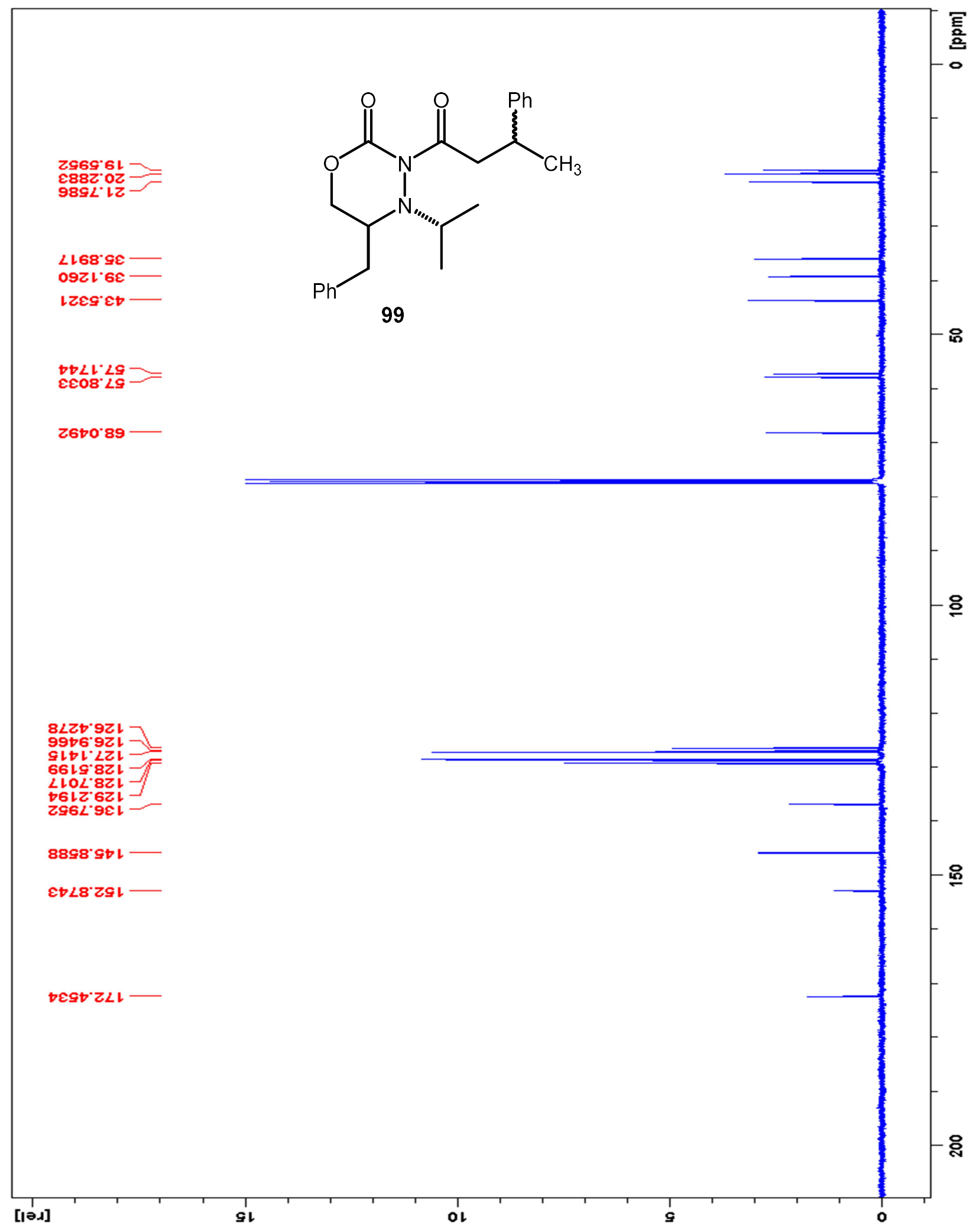


$500 \mathrm{MHz}{ }^{1} \mathrm{H}$ NMR spectrum of compound 112

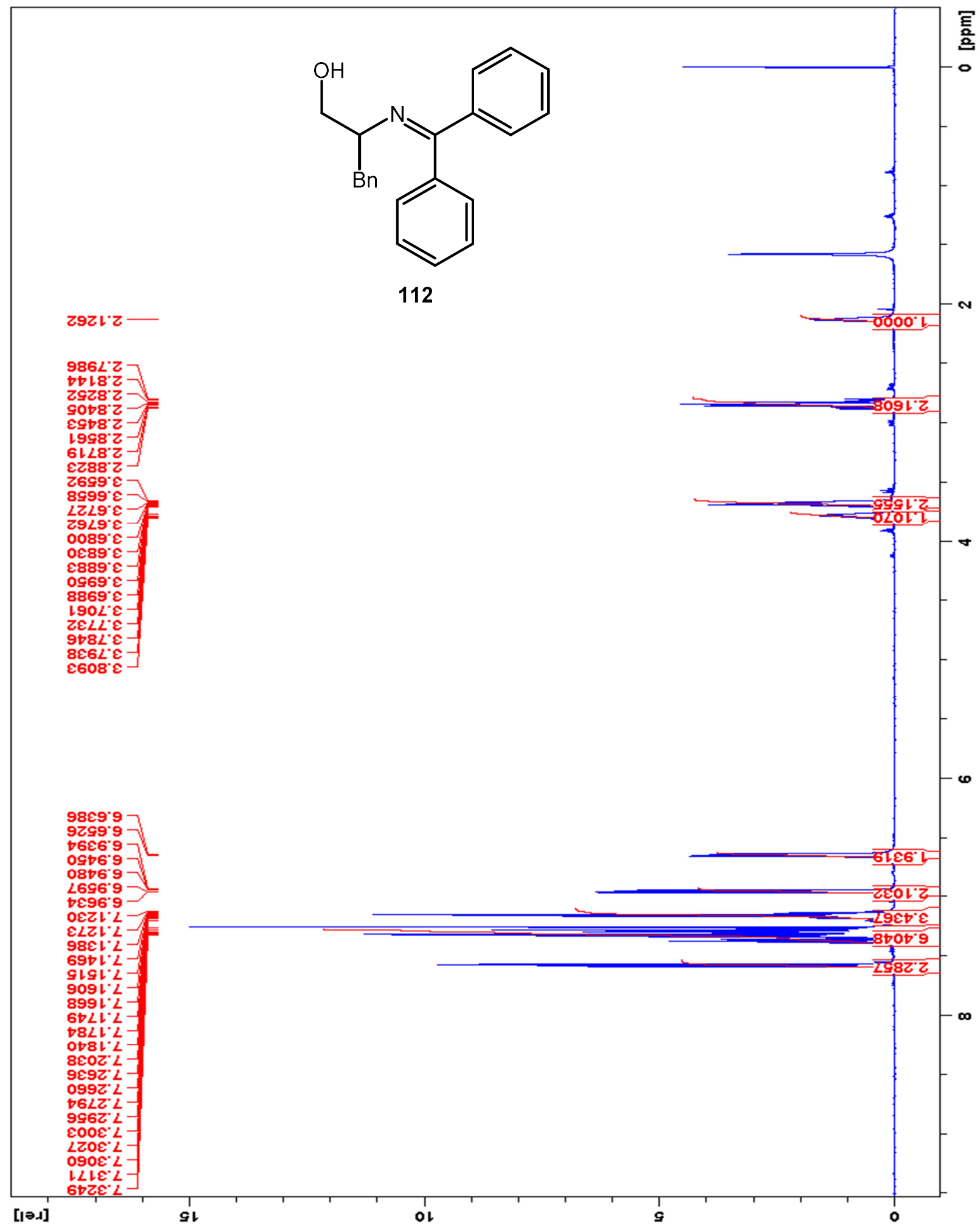


$100 \mathrm{MHz}{ }^{13} \mathrm{C}$ NMR spectrum of compound 112

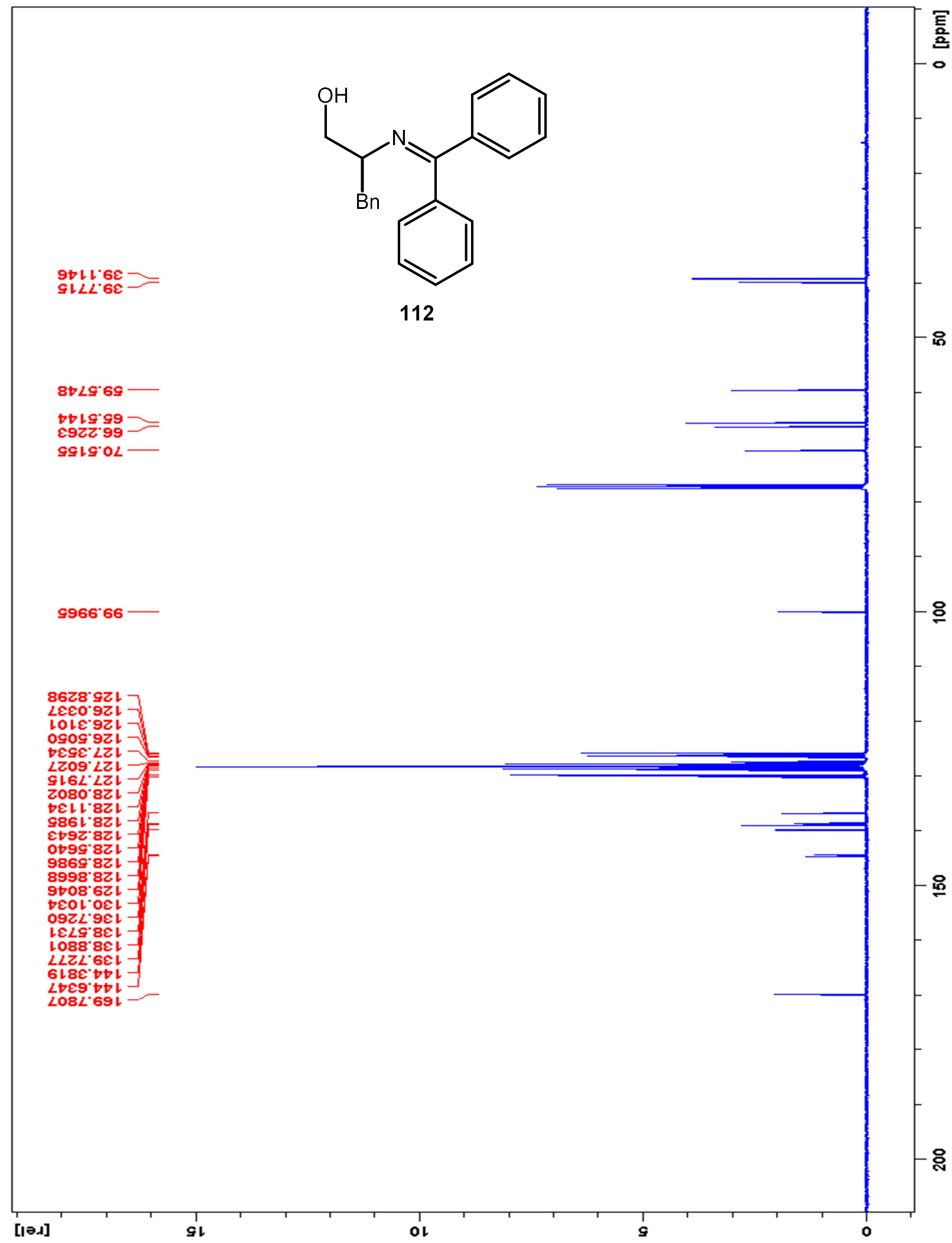


$500 \mathrm{MHz}{ }^{1} \mathrm{H}$ NMR spectrum of compound 113

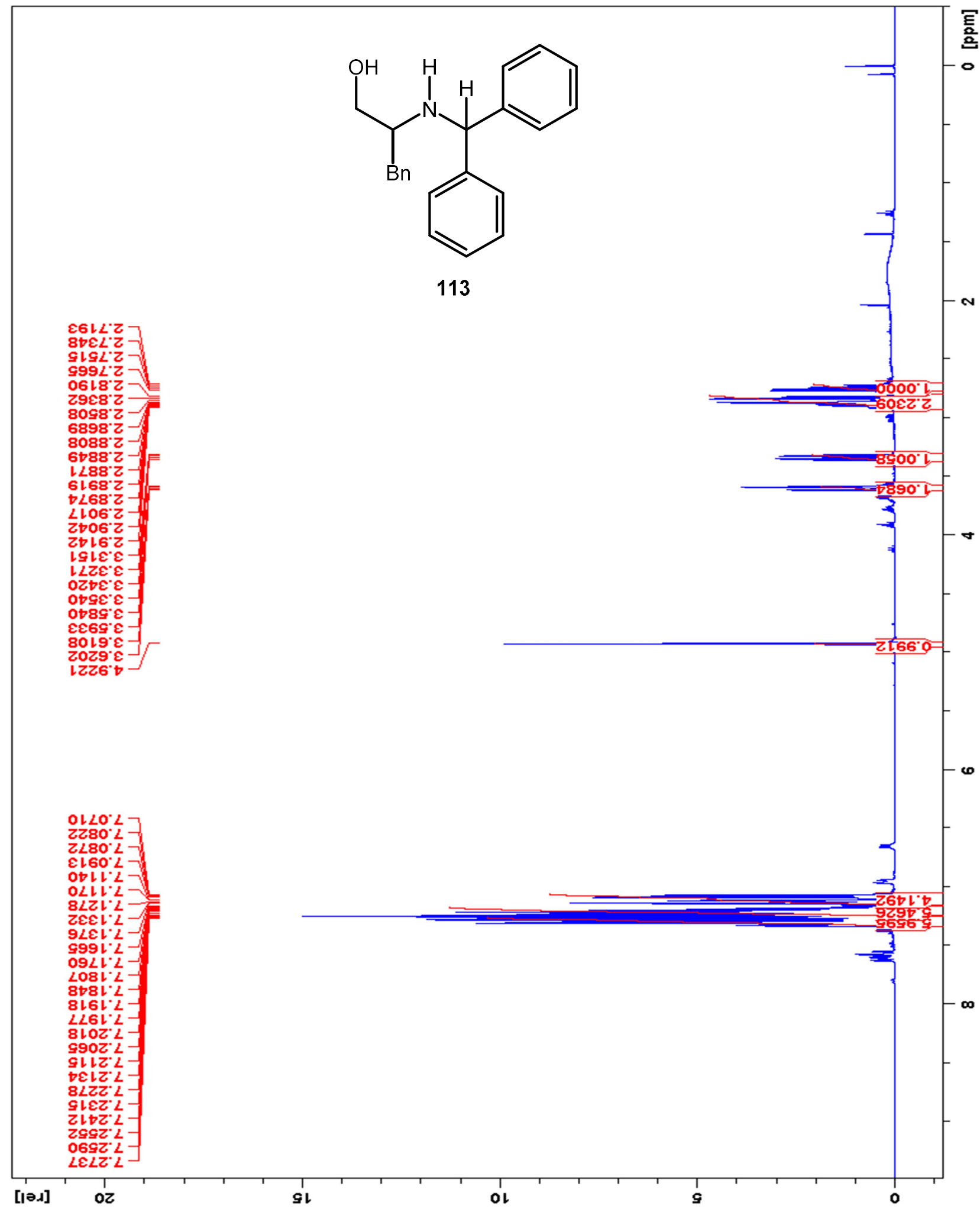


$100 \mathrm{MHz}{ }^{13} \mathrm{C}$ NMR spectrum of compound 113

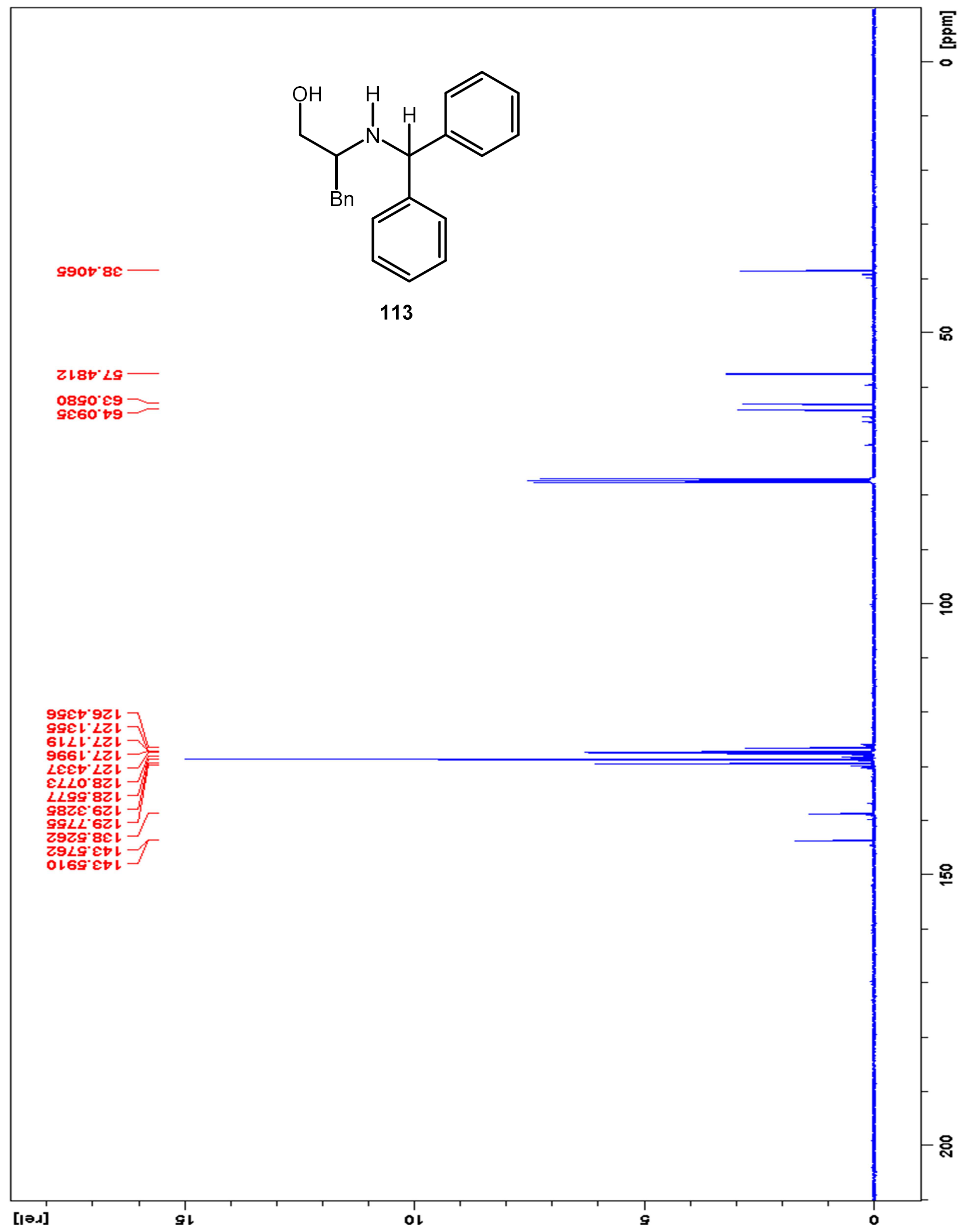


$500 \mathrm{MHz}{ }^{1} \mathrm{H}$ NMR spectrum of compound 114

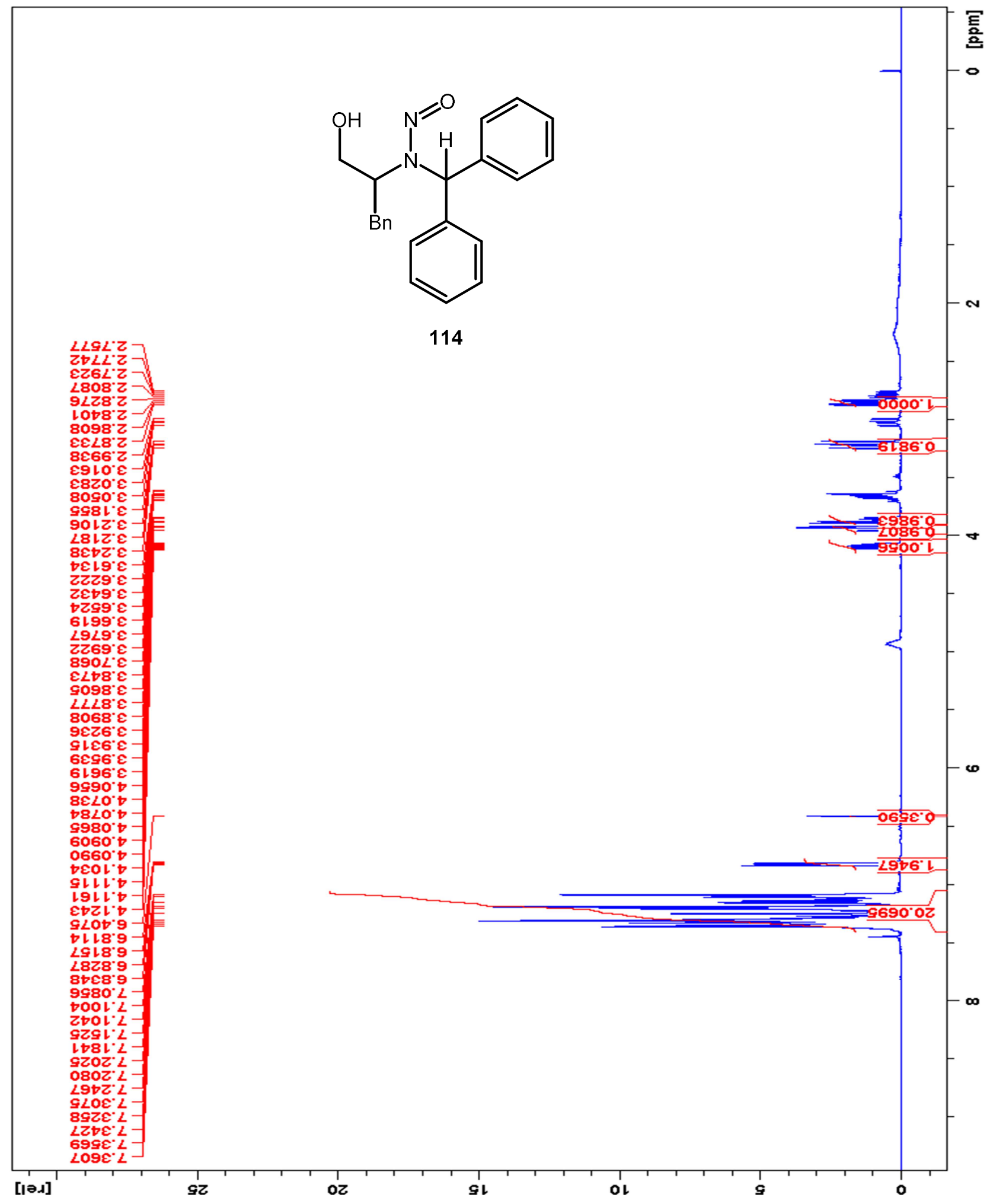


$100 \mathrm{MHz}{ }^{13} \mathrm{C}$ NMR spectrum of compound 114

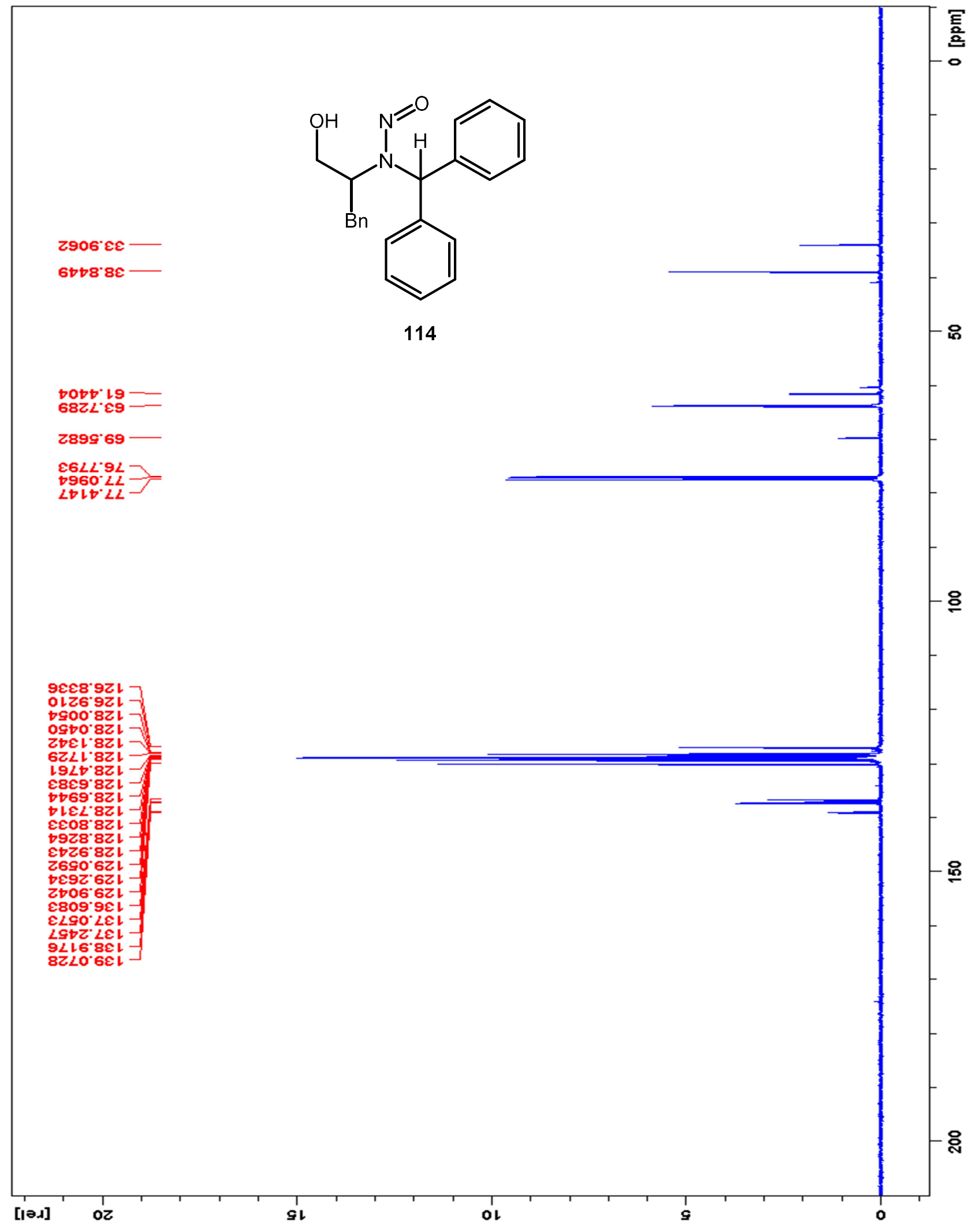

